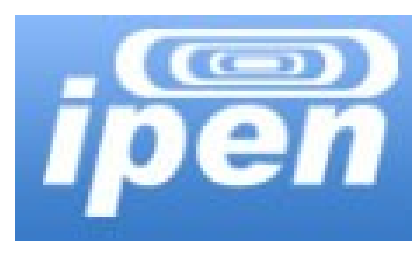

INSTITUTO DE PESQUISAS ENERGÉTICAS E NUCLEARES Autarquia associada à Universidade de São Paulo

\title{
ADESIVOS ESTRUTURAIS URETÂNICOS APLICADOS A COMBINAÇÕES DE COMPÓSITOS, PLÁSTICOS E METAIS
}

JOSUÉ GARCIA QUINI

Tese apresentada como parte dos requisitos para obtenção do Grau de Doutor em Tecnologia Nuclear - Materiais

Orientador: Dr Gerson Marinucci

SÃO PAULO 
Ao Prof. Dr. Gerson Marinucci, agradeço pela orientação, apoio e constante incentivo.

À minha esposa Andréia pelo carinho, apoio e compreensão,

Aos meus pais e minha familia pelo apoio durante estes anos de estudo,

Ao Sr Kristian Orberg pela oportunidade de conciliar o trabalho com a pesquisa,

À Masterpol Tecnologia em Adesivos pelo apoio e fornecimento dos materiais,

À Dr Cláudia Giovedi Mota pela colaboração e sugestões referentes a análise térmica e espectroscopia infravermelho ATR.

Agradeço e desejo a todos muito sucesso. 
Tua é, Senhor, a magnificência, e o poder, e a honra, e a vitória, e a majestade, pois teu é tudo o que há nos céus e na terra. Teu é, Senhor, o reino, e tu te exaltaste sobre todos como chefe. Riquezas e glória vêm de ti; tu dominas sobre tudo. Nas tuas mãos há força e poder para engrandecer e dar força a tudo. Agora, ó nosso Deus, graças te damos, e louvamos o nome da tua glória. I Crônicas 29:11 - 13 


\title{
ADESIVOS ESTRUTURAIS URETÂNICOS APLICADOS A COMBINAÇÕES DE COMPÓSITOS, PLÁSTICOS E METAIS
}

\author{
JOSUÉ GARCIA QUINI
}

\section{RESUMO}

Neste trabalho foram avaliadas as propriedades de um adesivo estrutural uretânico que visavam colagens de peças automotivas compostas por combinações de compósitos, termoplásticos e metais, que requerem do adesivo um elevado desempenho e compatibilidade com esses materiais. Para tanto, foram avaliadas as resistências ao cisalhamento de juntas formadas com estes substratos e o adesivo uretânico em diversas condições de exposição, que visam simular os efeitos deletérios que estas juntas estarão expostas durante sua utilização. Estes métodos permitiram caracterizar o adesivo como estrutural para tais aplicações, pois em todos os ensaios a fratura se deu fora da área de colagem, levando a conclusão de que a junta formada é mais resistente do que o substrato isoladamente. Foram desenvolvidos dois inovadores tratamentos de superfície alternativos ao lixamento, que foram o desengraxe com solventes e tratamento com plasma. Estes tratamentos tem contribuído significativamente om a comunidade e a partir deste estudo tem sido utilizados na indústria. A avaliação do comportamento térmico do adesivo e dos substratos permitiu o desenvolvimento de métodos de análise da composição das frações de massa de matriz polimérica, cargas minerais e fibra de vidro de modo prático, rápido e preciso, por uso da termogravimetria. A calorimetria diferencial exploratória possibilitou avaliar as transições vítreas dos substratos e do adesivo, bem como a energia liberada na reação do adesivo uretânico. Os fenômenos de interação química entre o adesivo e os substratos foram investigados pelo uso da técnica de espectroscopia infravermelho por reflectância atenuada, onde pode-se de forma inédita comprovar a existência de reações covalentes e de hidrogênio entre o adesivo e os substratos, que explicam a elevada aderência deste adesivo. Os resultados de todos os ensaios e análises levam à conclusão final que o adesivo uretânico, embora muitas vezes não considerado como estrutural, é um candidato plenamente capacitado ao trabalho de adesão estrutural, especialmente para uso automotivo nas condições descritas neste trabalho. 


\title{
STRUCTURAL URETHANE ADHESIVES APPLIED IN
}

\section{COMBINATION OF COMPOSITES, PLASTICS AND METALS}

\section{JOSUÉ GARCIA QUINI}

\begin{abstract}
In this study there were evaluated the properties of a structural urethane adhesive used for bonding automotive parts made from combinations of composites, thermoplastics and metals, which require a high adhesive performance and compatibility with these materials. Thus, there were evaluated the shear strength of joints formed with these substrates and adhesive urethane different exposure conditions, which aim to simulate the deleterious effects that these joints are exposed during their use. These methods allowed characterization like structural adhesive for these applications, because in all tests the fracture occurred outside the area of bonding, leading to the conclusion that the joint formed is stronger than the substrate alone. There were developed two innovative surface treatments alternative to grinding, which was a degreasing solvent and treatment with plasma. These methods have significantly contributed to the community and from this study has been used in industry. The evaluation of the thermal behavior of the adhesive and the substrates allowed the development of methods for analyzing the composition of mass fractions of polymer matrix, fillers and fiberglass in a practical, fast and accurate, by use of thermogravimetry. The differential scanning calorimetry allowed to evaluate the glass transitions of substrates and adhesive, and the energy released in the reaction of urethane adhesive. The phenomena of chemical interaction between the adhesive and the substrates were investigated by use of infrared spectroscopy by attenuated reflectance, where it can be in an unprecedented way to prove the existence of covalent and hydrogen reactions between the adhesive and the substrates, which explains the high adhesion of this adhesive.The results of all testing and analysis lead to the final conclusion that the adhesive urethane, although often not considered as structural, is a fully qualified candidate for structural work of adhesion, especially for automotive use under the conditions described in this thesis.
\end{abstract}




\section{SUMÁRIO}

1. Introdução

Página

2. Objetivos

3. Abordagem Teórica 12

3.1. Poliuretano 12

3.2. Adesivos Estruturais 13

3.3. Compósitos 16

3.3.1. Moldagem por transferência - RTM 19

3.3.2. Moldagem por prensagem - SMC 19

3.4. Teorias da adesão 22

3.4.1. Teoria da adsorção 24

3.4.2. Teoria mecânica 26

3.4.3. Teoria eletrostática 26

3.4.4. Teoria da difusão $\quad 27$

3.4.5. Teoria da camada de interface $\quad 27$

3.5. Superfície de contato 28

3.6. Tratamento de superfície 30

3.6.1. Metais 32

3.6.2. Plásticos 34

3.6.3.Compósitos poliméricos $\quad 35$

3.6.4. Fibras 36

3.6.5. Materiais inorgânicos 36

3.6.6. Madeira 37

3.7. Projeto de junta $\quad 37$

4. Pesquisa bibliográfica 40

5. Materiais empregados 41

5.1. Adesivo uretânico 41

5.2. Substratos 43

5.2.1. Metais $\quad 43$

5.2.2. Plásticos 44

5.2.3. Compósitos 45

6. Métodos 46

6.1. Preparação dos corpos de prova para o ensaio de resistência ao 46 cisalhamento

6.2. Acondicionamento dos corpos de prova 49

6.3. Preparação dos corpos de prova para ensaio de tração 50

6.4. Preparação dos corpos de prova para ensaio de resistência a clivagem $\quad 52$

6.5. Métodos de preparação de superfície $\quad 54$

6.5.1. Exposição ao plasma

6.5.2. Limpeza co solventes 56

6.6. Análise térmica 56

6.6.1. Termogravimetria (TG) 57

6.6.2. Calorimetria diferencial exploratória (DSC) 57

6.7. Espectroscopia vibracional na região do infravermelho por 58

reflectância atenuada (ATR)

7. Resultados e discussão 60

7.1. Caracterização mecânica do adesivo $\quad 60$

7.2. Caracterização mecânica dos substratos $\quad 61$ 
7.3. Resistência ao cisalhamento de juntas coladas a temperatura

ambiente

7.4. Efeito das condições externas na resistência ao cisalhamento

71

7.4.1. Efeito da temperatura da junta na resistência ao cisalhamento 71

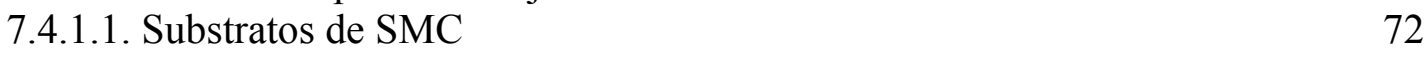

$\begin{array}{ll}\text { 7.4.1.2. Substratos de RTM } & 73\end{array}$

7.4.1.3. Substratos de ABS

7.4.1.4. Substratos de aço carbono zincado e cromado preto 76

7.4.2. Efeito da temperatura e tempo de exposição na resistência ao 78

cisalhamento

7.4.3. Efeito da temperatura, tempo e umidade relativa na resistência ao 80

cisalhamento

7.4.4. Efeito da imersão em água destilada na resistência ao cisalhamento $\quad 81$

7.4.5.Efeito da névoa salina na resistência ao cisalhamento 83

7.4.6. Efeito combinado de temperatura, tempo, umidade e névoa salina $\quad 84$

na resistência ao cisalhamento

7.4.7. Comparação do efeito das condições externas 86

7.5. Avaliação da resistência a clivagem $\quad 89$

$\begin{array}{ll}\text { 7.6. Tratamentos de superfície } & 91\end{array}$

7.6.1. Tratamento com plasma

7.6.2. Limpeza co solvente $\quad 92$

7.7. Avaliação das propriedades térmicas 95

7.7.1. Termogravimetria (TG) 96

7.7.1.1. Termogravimetria do adesivo uretânico 96

$\begin{array}{ll}\text { 7.7.1.2. Termogravimetria dos substratos } & 101\end{array}$

7.7.2. Calorimetria diferencial exploratória (DSC) 104

7.8. Espectroscopia vibracional na região do infravermelho por 108

reflectância atenuada

$\begin{array}{ll}\text { 8. Conclusão } & 117\end{array}$

9. Sugestões para trabalhos futuros 118

$\begin{array}{ll}\text { Bibliografia } & 119\end{array}$

$\begin{array}{ll}\text { Anexo A - Poliuretanos } & 125\end{array}$

Anexo B - Projeto de Junta $\quad 130$

$\begin{array}{ll}\text { Anexo C - Adesivo uretânico } & 135\end{array}$

Anexo D - Tratamento com Plasma 138 


\section{Introdução}

Nos últimos anos a tecnologia dos adesivos estruturais tem demonstrado um grande potencial de aplicação devido à sua capacidade de transformar estruturas complexas em montagens sólidas unitárias e monolíticas utilizando diferentes materiais. Assim, emendas ou junções passam a integrar as referidas estruturas propiciando, além da redução de peso, um aumento considerável da resistência mecânica e rigidez (Yarlagadda et al,1999, Kinloch et al, 2000, Edwards et al, 1998). Os adesivos para tais aplicações apresentam propriedades atrativas do ponto de vista químico e mecânico que ainda não foram suficientemente estudadas ou mesmo compreendidas, resultado talvez da complexidade existente nas interações entre o substrato e o adesivo. O que se encontra disponível são teorias baseadas em adsorção, difusão, ancoramento mecânico, interações químicas e eletrostáticas e forças secundárias da interface adesivo/substrato que são aplicáveis aos adesivos estruturais a base de epóxi e metacrilato de metila. (Petrie, 2000, p. 355-392).

O uso de adesivos estruturais tem se intensificado na indústria do compósito por serem capazes de unir eficientemente materiais diferentes de forma irreversível, substituindo inclusive sistemas de fixação mecânica (Adderley, 1988, Parker, 1994). Tal avanço deve-se em parte ao conhecimento adquirido na indústria aeroespacial, onde os primeiros estudos de preparação de superfície, metodologia de testes e projeto de junta foram concebidos dando então, maior credibilidade ao conceito de adesão estrutural. Um importante exemplo dessa técnica são os aviões militares F-18 que tem as asas em compósito de fibra de carbono coladas a uma estrutura lateral de titânio a partir de um desenho de junta apropriado que distribui o esforço mecânico (Petrie, 2000, p. 657-672).

No Brasil, o uso de adesivos estruturais para veículos de transporte iniciou-se nos anos oitenta pela necessidade encontrada em seguir especificações elaboradas pelas matrizes de algumas das montadoras multinacionais na colagem de capôs, grades e pára-choques produzidos em compósitos de poliéster e fibra de vidro. Deste modo, passou-se então a utilizar, para essas aplicações, um adesivo de poliuretano bicomponente importado. A partir do sucesso da utilização do poliuretano, o conceito de colagens estruturais evoluiu e hoje em dia, praticamente todas as montadoras de veículos de transporte de carga e de passageiros empregam a técnica utilizando adesivos uretânicos, epóxis e metacrilatos. Outras aplicações envolvem a fabricação de lanchas, veleiros, jet skis, hélices dos captadores 
de energia eólica, tubulações, aeronaves e peças técnicas em geral que também têm utilizado com maior frequência os adesivos estruturais.

Embora ainda grande parte dos fabricantes de peças em compósito não mostre confiança no uso do adesivo, fato possivelmente atribuído à falta de informação e ausência de condições adequadas para trabalhar com o adesivo, o crescente consumo observado nos últimos 15 anos apresenta uma perspectiva e ampliação do uso e pesquisa neste campo do conhecimento. Com isso, mais empresas passaram a ter o que pode ser chamado de cultura do adesivo, pela qual ocorre a união permanente de uma junta de compósito, desde que aplicado de maneira correta e seguindo os princípios básicos de preparação de superfície, dosagem correta, mistura dos componentes do adesivo e projeto adequado da junta (Quini, 2005).

A união de peças de compósito por meio de adesivos estruturais oferece benefícios significativos em relação aos sistemas convencionais de junção, como por exemplo, parafusos, insertos roscados ou rebites (Shields, 1976, p. 1-7). O adesivo distribui as cargas e tensões atuantes sobre a área total da união ao invés de concentrá-las, permitindo, além da distribuição uniforme das cargas estáticas e dinâmicas, uma redução nos custos de produção e manutenção em relação aos sistemas mecânicos de fixação (Skeist, 1965). Garante ainda melhor isolamento elétrico, redução da corrosão e também redução dos níveis de vibração em montagens com parafusos e rebites, sendo que industrialmente, em muitos casos, os métodos de aplicação de adesivo oferecem maior produtividade nos processos de montagem (Ashcroft et al., 2001).

Outra grande vantagem, consequência de uma boa adesão, é a melhor vedação entre as partes unidas, evitando a passagem de fluidos pela junta e dispensando a necessidade de impermeabilização complementar.

É importante salientar que a fixação mecânica pode promover nos compósitos a delaminação, criando uma falha que pode ser catastrófica e que também, dependendo da temperatura de exposição e da diferença de coeficiente de expansão térmica entre as partes, faz surgir uma elevada tensão na junta, comprometendo a integridade física do compósito (Goeij et al., 1999).

$\mathrm{Na}$ literatura há uma grande concentração de trabalhos envolvendo adesivos estruturais que abordam estudos dos adesivos do tipo epóxi e metacrilato, atribuída possivelmente a sua maior utilização. Adesivos estruturais uretânicos, apesar de oferecerem um grande potencial de aplicação, têm inversamente um número menor de publicações, resultado da quantidade 
menor de estudos envolvendo o adesivo. Uma das áreas carentes de pesquisa está relacionada ao estudo da interação química e do comportamento mecânico de adesivos uretânicos e substratos de grande utilização na engenharia, como compósitos, materiais metálicos e termoplásticos, que caracteriza o ineditismo da proposta deste trabalho. 


\section{Objetivos}

A extensa utilização de juntas coladas na indústria automobilística motivou o desenvolvimento deste trabalho em que foram feitas avaliações das propriedades de juntas de compósitos poliéster/fibra de vidro, de termoplásticos e de metais utilizando adesivos estruturais uretânicos por meio de ensaios de resistência ao cisalhamento em diferentes condições de exposição, tais como umidade, névoa salina, envelhecimento acelerado por temperatura, bem como em ciclos de exposição combinado.

Também foram estudados os fenômenos de adesão existentes entre o adesivo e os compósitos por meio de espectroscopia vibracional na região do infravermelho(IR) e o comportamento térmico do adesivo uretânico e dos substratos utilizando as técnicas de análise térmica TG e DSC. 


\section{Abordagem teórica}

A abordagem teórica dos conceitos relacionados aos adesivos estruturais se faz necessária para melhor compreensão do trabalho.

\subsection{Poliuretano}

Os poliuretanos foram desenvolvidos por Otto Bayer em 1937 a partir da reação de dois compostos que resultava em um produto de estrutura macromolecular, tornando-se uma fantástica história de sucesso e um negócio que atualmente envolve bilhões de dólares. São normalmente produzidos pela reação de poliadição de um isocianato, que pode ser bifuncional ou polifuncional e um poliol (Vilar, 2002).

O desenvolvimento comercial dos poliuretanos começou na Alemanha no final dos anos 30, com o uso crescente década após década. Inicialmente o material permitiu a fabricação de espumas rígidas e adesivos. Nas décadas de 40 e 50, surgiram respectivamente os elastômeros e as espumas flexíveis. Durante a década de 60 passou-se a utilizá-los em tintas e vernizes. Neste mesmo período o uso de clorofluorcarbonos (CFC) como agente de expansão das espumas rígidas resultou no grande emprego deste material em isolamento térmico. $\mathrm{Na}$ década de 70 foram desenvolvidas as espumas semi-flexíveis e semi -rígidas revestidas com materiais termoplásticos, que foram bastante usadas na indústria automotiva. Na década de 80 o crescimento comercial veio da moldagem por injeção, acompanhado pela reação (RIM) na década de 90. No início deste milênio, devido à preocupação com o meio ambiente, tem sido desenvolvidas pesquisas para substituição do CFC, sistemas sem compostos orgânicos voláteis e processos de reciclagem do poliuretano (Wikipédia, 2011).

Os compostos contendo hidroxilas podem variar quanto à massa molar, natureza química e funcionalidade, podendo ser poliéteres, poliésteres ou possuir estrutura hidrocarbônica. Os isocianatos podem ser aromáticos, alifáticos, cicloalifáticos ou policíclicos. Esta flexibilidade de escolha de reagentes permite obter uma grande variedade de compostos com diferentes propriedades físicas e químicas, conferindo aos poliuretanos uma posição importante no mercado mundial de polímeros sintéticos de alto desempenho. Informações adicionais podem ser encontradas sobre os isocianatos no Anexo A. 


\subsection{Adesivos Estruturais}

Os adesivos estruturais são polímeros termofixos rígidos ou elastoméricos formados pela reação química de dois componentes que apresentam elevadas propriedades mecânicas e boa resistência química (Skeist, 1965). Na união de dois substratos proporcionada pelo adesivo estrutural, conhecida por junta, é desejável que esta quando submetida a um esforço mecânico apresente ruptura do substrato sem promover dano na região de adesão.

O comportamento mecânico da junta não depende apenas do adesivo, mas também do desenho da junta, do tipo de substrato empregado e do método de aplicação, sendo um processo que envolve algumas variáveis. Ressalta-se também que o adesivo estrutural não deve ser utilizado com o mesmo critério que se aplica em métodos convencionais de união, como solda por exemplo, pois suas propriedades mecânicas são por vezes muito inferiores as dos substratos. Contudo, conforme o desenho da junta, os adesivos estruturais podem ainda assim ser empregados e possibilitam uma união bastante eficiente de dois substratos (Petrie, 2000, p. 93-127). Atualmente vários materiais poliméricos são utilizados como adesivos estruturais, dentre eles os mais importantes são:

Uretano: formado pela reação de polióis com blendas de isocianatos, possui elevada aderência sobre metais, plásticos, compósitos e plásticos de engenharia, apresentando baixa contração, alta deformação e baixa exotermia na polimerização, também chamada de cura. Apresenta elevada propriedade adesiva, coesiva e resistência química. Exige, no entanto, boa preparação de superfície e é sensível a variação na proporção de mistura. Atualmente os adesivos uretânicos são bastante utilizados em diferentes aplicações industriais, envolvendo materiais termofixos, termoplásticos e termo fusíveis (Kovacevid et al, 1993).

* Epóxi: derivado da epicloridrina, polimerizável por endurecedores amínicos, amídicos, mercaptanos ou anidridos, possui elevada resistência coesiva e tenacidade, adesão sobre enorme gama de substratos e resistência química, no entanto é, em geral, muito rígido e apresenta tempos de cura longos (Wright et al, 1986).

Metacrilato: derivado de monômeros acrílicos e polimerizado por peróxidos orgânicos, possui excelente adesão em materiais plásticos com pequena ou nenhuma preparação de superfície, tempos de cura curtos e permite preenchimentos com elevada espessura, 
porém apresenta forte odor irritante, alta exotermia, tempo de vida útil reduzido e deve ser armazenado sob refrigeração (Morganelli et al, 1998).

A aplicação de adesivos estruturais para união de peças em compósitos é feita industrialmente por processos de aplicação manuais ou mecanizados. Dependendo do volume de produção de uma determinada peça em compósito, um ou outro método poderá ser empregado. Por exemplo, para um para-choque de um caminhão que tem insertos metálicos colados na estrutura de compósito, com um volume de produção relativamente elevado, não é conveniente dispor de um método de aplicação manual, ao invés disso empregam-se equipamentos pneumáticos. $\mathrm{O}$ mesmo não ocorre em aplicações na área náutica, por exemplo, o fechamento de casco e convés de um barco consiste em uma operação realizada com pouca frequência em um estaleiro, sendo geralmente feita pela dosagem, mistura e aplicação na forma manual.

Como os adesivos estruturais são compostos por dois componentes e requerem uma dosagem precisa e posterior mistura, algumas empresas têm desenvolvido equipamentos utilizando dois modos de dosagem, um deles é a dosagem por bombas de engrenagem que pelo ajuste da rotação dosam adequadamente cada um dos componentes. Outro modo de dosagem é por uso de dosadores tubulares com diferentes diâmetros capazes de dosar na proporção adequada os componentes. Uma vez dosados os componentes seguem caminho por mangueiras até a pistola de aplicação onde serão misturados e aplicados na peça a ser colada.

O processo de mistura dos dois componentes é feito em um bico misturador, este bico é formado por um tubo plástico de 10 a $15 \mathrm{~mm}$ de diâmetro contendo pequenas pás denominadas elementos de mistura. Na FIG. 1 está ilustrado o processo de mistura, onde os dois componentes entram separadamente e tem o primeiro contato. Conforme os componentes do adesivo seguem pelo tubo, estas pás dividem os componentes e aumentam o contato proporcionando uma mistura forma homogênea. Dependendo da viscosidade, tixotropia e tempo de reação do adesivo estes bicos misturadores contem um número determinado de elementos de mistura que podem variar de 10 a 50 elementos (Kirsch, 2002). 


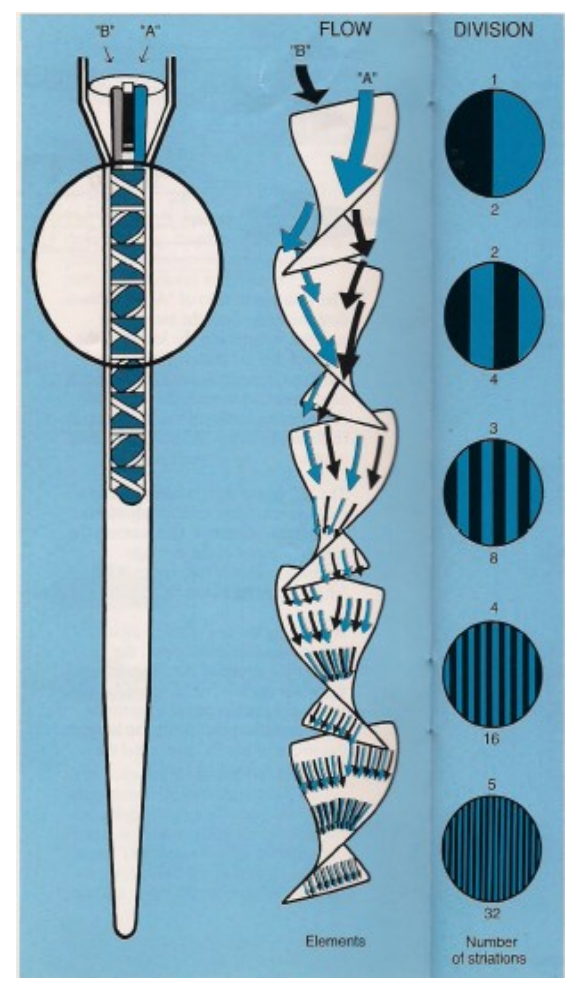

FIGURA 1 - Misturador estático para adesivos bicomponentes (Liquid Control Corp, 1996).

A FIG. 2 mostra equipamentos dosadores de adesivos. Estes equipamentos podem ser para elevados consumo e alimentados por tambores metálicos de 50 a $200 \mathrm{~kg}$, ou podem ser portáteis como pistolas pneumáticas alimentadas por cartuchos de 50 a $500 \mathrm{~g}$.

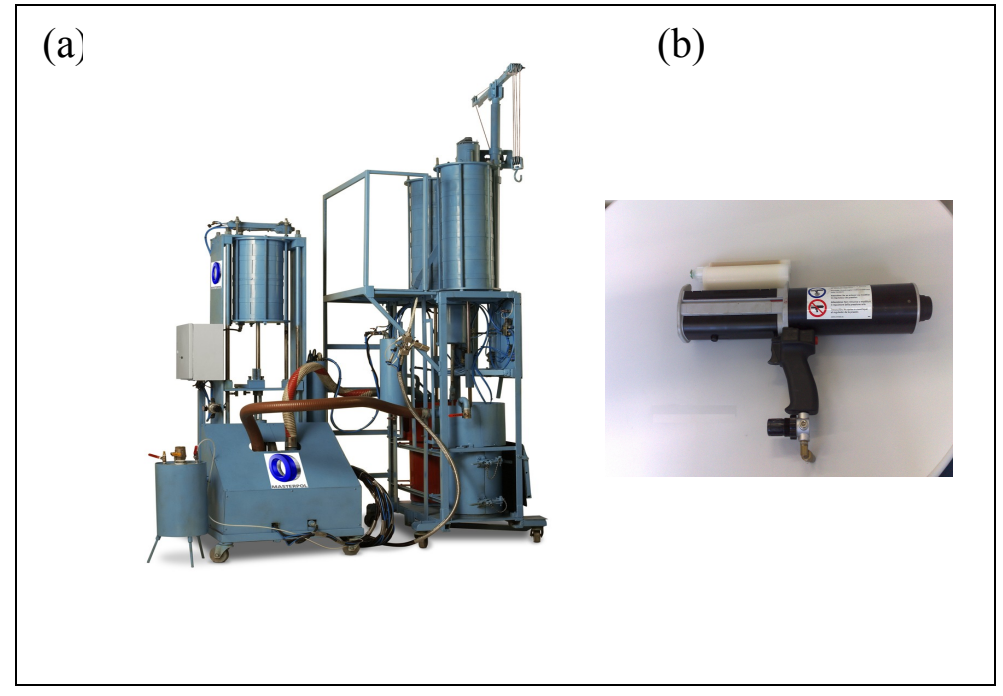

FIGURA 2 - (a) Equipamento pneumático alimentado por tambor, (b) pistola pneumática alimentada por cartucho (Masterpol Adesivos, 2011). 
A montagem de uma peça em compósito por meio do uso dos adesivos estruturais é feita basicamente pela aplicação do adesivo em uma das partes seguida do posicionamento da mesma e fixação por meio de um gabarito para manter a peça unida até a cura parcial do adesivo. Esta cura pode ser acelerada por uso de aquecimento do conjunto. Na FIG. 3 é mostrada a aplicação do adesivo estrutural em um inserto metálico e o posicionamento dele sobre o substrato de compósito de RTM. Nota-se que nas extremidades do inserto existem furos feitos propositalmente para permitir que o adesivo passe por eles formando um rebite. Este rebite tem a função de garantir a fixação do inserto, formando uma fixação mecânica, o que não é feito com a colagem é entre RTM x RTM.

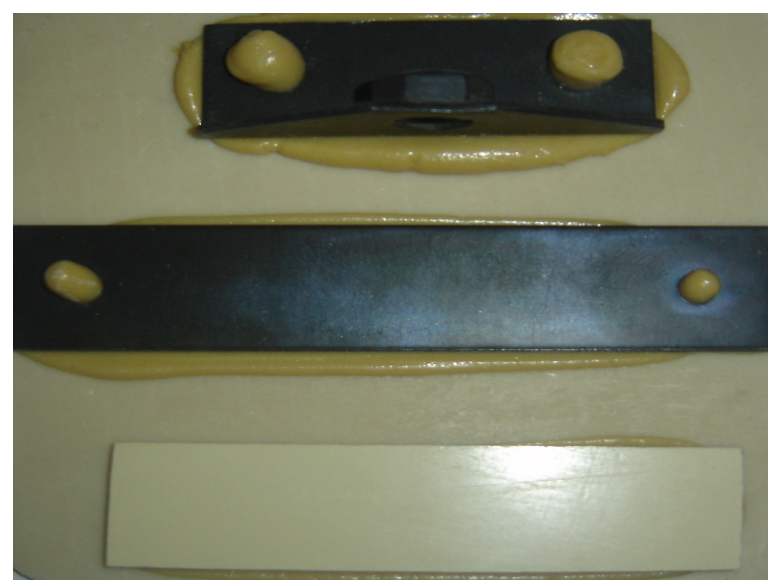

FIGURA 3 - Colagem de inserto metálico sobre substrato compósito.

\subsection{Compósitos}

São materiais que apresentam dois ou mais constituintes fisicamente diferentes, exibindo na escala macroscópica uma interface bem definida entre eles. Em geral este termo é empregado para materiais formados pela impregnação de uma fibra, que apresenta elevadas propriedades mecânicas, com uma matriz polimérica. As propriedades finais do compósito dependem das propriedades dos elementos constituintes, como concentração, distribuição da concentração, orientação e geometria das fibras (Marinucci, 2007).

A concentração é usualmente medida em termos de massa ou fração volumétrica, que representa a contribuição dos elementos constituintes em relação ao compósito. A distribuição da concentração é a medida da homogeneidade ou uniformidade, que determina quanto um 
volume representativo do material pode diferir nas propriedades físicas e mecânicas em relação às propriedades médias do material (AL-QURESHI, 1984).

A orientação do reforço afeta a isotropia do sistema, tornando as propriedades mecânicas dependentes das direções do reforço no compósito. Quando o reforço está na forma de partículas, com todas as dimensões aproximadamente iguais, o compósito comporta-se como um material considerado isotrópico. Se utilizado na forma de fibras curtas, a distribuição será aleatória, podendo resultar em um comportamento quase isotrópico do compósito. Em processos em que as fibras são orientadas em determinadas direções, principalmente naqueles que utilizam fibras contínuas, o comportamento é considerado como anisotrópico, ou seja, as propriedades mecânicas não serão as mesmas em todas as direções. Esta anisotropia pode ser desejável em alguns casos e controlada pelo projeto e pelo método de fabricação (AGARWAL et al, 1980) .

O Brasil é um dos maiores fabricantes mundiais de ônibus, micro-ônibus, caminhões, veículos de uso agrícola e automóveis de passeio. Este fato se deve aos investimentos das montadoras e ao constante crescimento deste segmento, o que representa um excelente potencial de desenvolvimento para a indústria de compósitos.

A utilização dos materiais compósitos oferece vantagens competitivas no setor automotivo devido, entre elas, a versatilidade de modificações de desenho, o que tem contribuído muito para o seu crescente uso.

Atualmente em veículos de passeio, os modelos são modificados quase que a cada ano, enquanto que os modelos de caminhões, ônibus e tratores em média a cada cinco anos. Isto requer que os fabricantes de peças automotivas tenham que alterar com frequência seu ferramental para atender novos projetos.

O uso dos compósitos em peças automotivas tem sido favorecido quando os volumes de produção não são tão elevados, como por exemplo, na fabricação de peças para ônibus, caminhões e tratores. Nesta situação, o custo de fabricação dos moldes para peças em compósito não é tão elevado quanto um molde para estamparia de peças metálicas, tornando viável sua amortização ao longo do tempo. 
Dentre as diversas aplicações dos compósitos na indústria automotiva as principais são destinadas às partes externas dos veículos, como capôs, grades frontais, pára-choques, estribos, portas laterais e traseiras e são as que mais utilizam adesivos estruturais. Estes compósitos têm como características importantes a resistência ao impacto, resistência a vibração, aparência lisa e uniforme, sendo normalmente fabricadas pela combinação de matrizes poliméricas de poliéster insaturado e fibras de vidro picadas ou em tecidos, por processos de moldagem por transferência de resina (RTM e RTM light) e moldagem por prensagem (SMC e BMC). Estes processos permitem a produção de peças bem acabadas superficialmente e com alta produtividade.

\subsubsection{Moldagem por transferência - RTM}

Tem como princípio básico a injeção sob pressão da resina pré-acelerada e do iniciador de cura em uma cavidade onde o material de reforço está devidamente posicionado e delimitado por um par de moldes tipo macho-fêmea. Nesse processo, o reforço é colocado em um dos moldes, geralmente o molde fêmea e após o fechamento com um sistema adequado de garras a matriz é injetada com pressão em torno de 6 bar. Aguarda-se o tempo para cura da resina e após extração a peça segue para acabamento e pintura. A pressão, o tempo de injeção e o tempo de desmoldagem são dependentes da área da peça e da proporção de reforço na estrutura. O processo RTM é recomendado para produção de peças de pequena a médio porte, que podem variar entre $30 \mathrm{~cm}^{2}$ e $4 \mathrm{~m}^{2}$, com acabamento em ambos os lados e com escala de produção entre 10 e 80 peças por dia. A FIG. 4 ilustra um molde para este processo (BADER, 2003).

Como o processo é fechado, há uma melhora das condições de trabalho, propiciando uma redução de compostos orgânicos voláteis da resina ou estireno. Outra vantagem deste processo é a possibilidade da fabricação de peças de grande área superficial, que de outra forma seria inviável pelo processo SMC, devido à grande capacidade de prensagem que seria exigida dos equipamentos. 


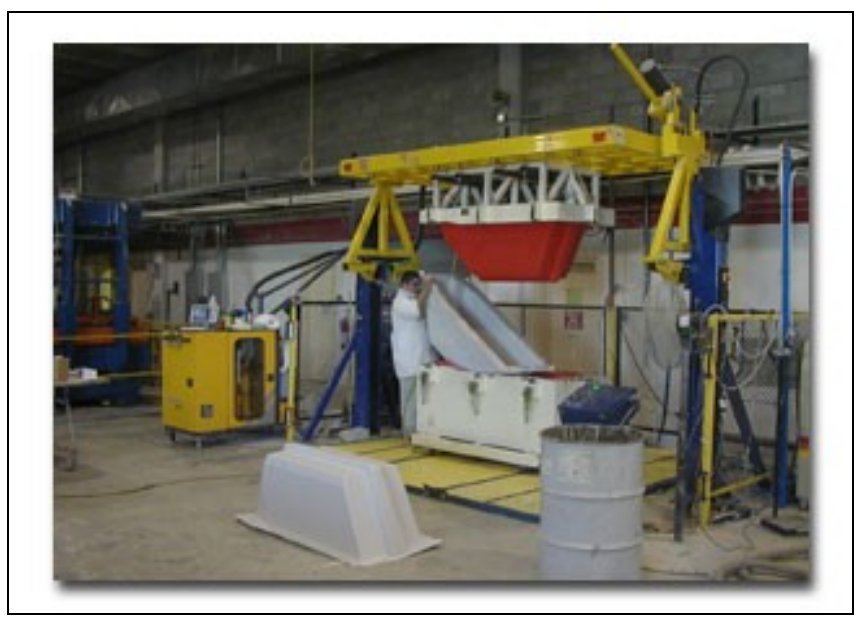

FIGURA 4 - Molde de RTM (Tecnofibras, Produtos, 2008).

Na FIG. 5 encontram-se aplicações de peças moldadas em RTM e que utilizam adesivos estruturais na montagem de seus componentes.

\subsubsection{Moldagem por Prensagem - SMC}

De forma semelhante aos processos de estamparia de chapas metálicas, são usados moldes aquecidos e prensas hidráulicas para conformação de uma massa contendo a matriz polimérica não curada e fibras de vidro. Este processo possibilita a fabricação de peças com elevada produtividade, por exemplo, entre 15 e 300 peças por dia, a baixa incidência de mãode-obra, a redução de desperdício de matérias-primas e permitem acabamento liso em ambas as faces da peça (FIGUEIREDO). A FIG. 6 ilustra uma prensa usada neste processo. 


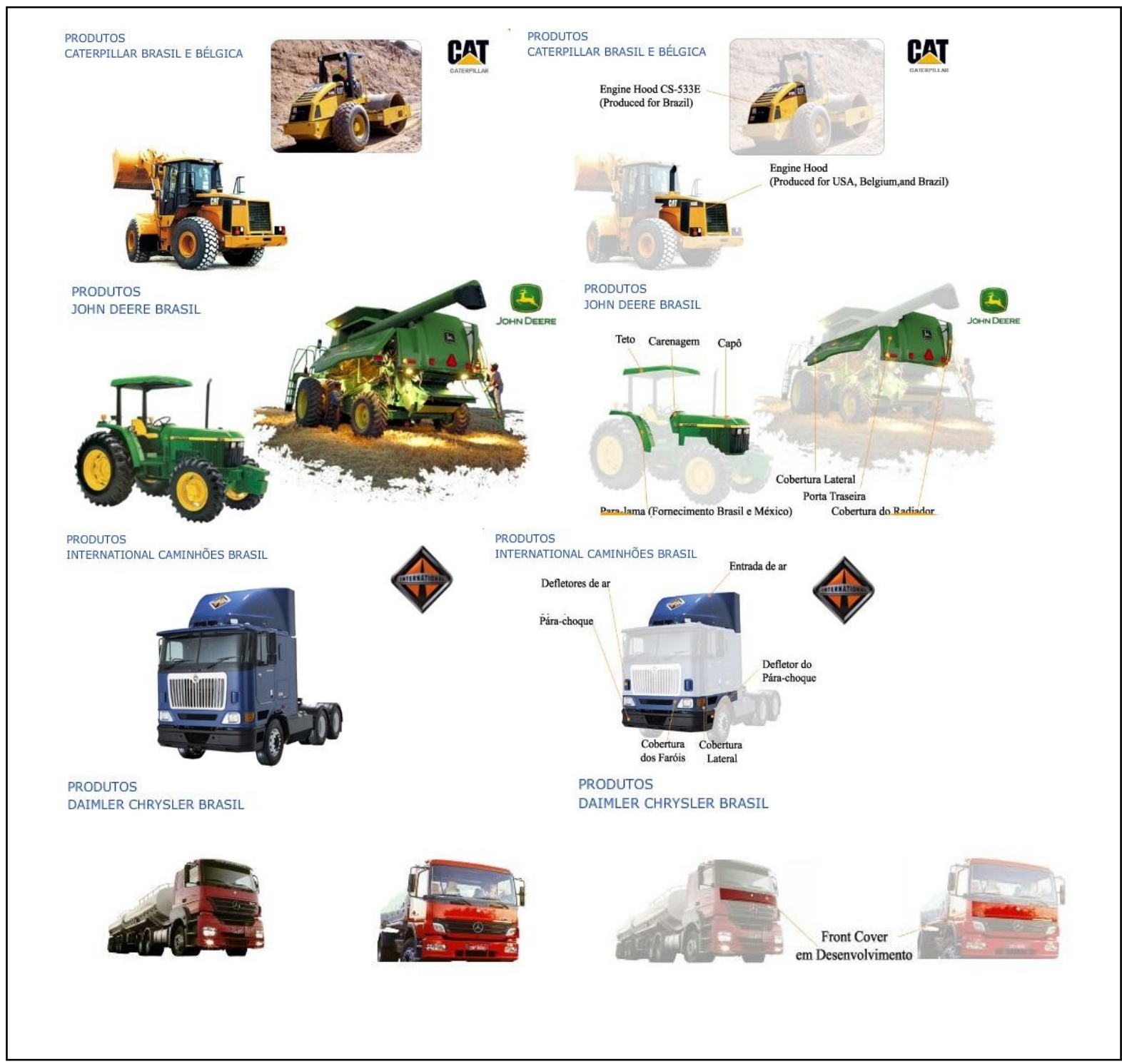

FIGURA 5 - Exemplos de peças moldadas em RTM (Tecnofibras, Produtos, 2008).

A massa polimérica, também chamada de manta, é constituída por fibra de vidro picada, resina poliéster, iniciador de cura, pigmento, aditivo termoplástico, agente desmoldante, espessante, inibidores e cargas minerais, podendo ainda ter absorvedores de radiação ultravioleta e retardantes de chama. Essas mantas têm entre 2 e $6 \mathrm{~mm}$ de espessura, contendo de 25 a 30\% de fibra de vidro. Para aplicações de uso automotivo é possível adquirir mantas com teores de até $50 \%$ de fibra picada para aplicações estruturais (Elekeiroz). 


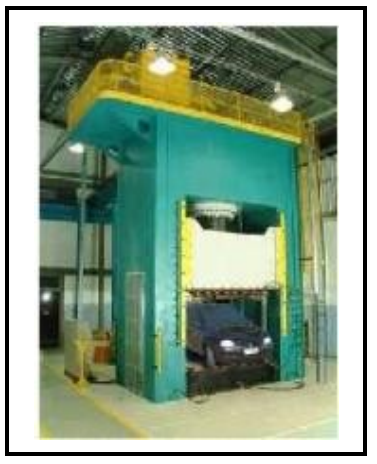

FIGURA 6 - Prensa Hidráulica (Tecnofibras, Produtos, 2008).

As mantas são fabricadas em rolos ou bobinas pela deposição uniforme de fibra picada sobre uma massa polimérica, que é envolvida em ambos os lados por um filme de polietileno. O conjunto é comprimido por rolos de compactação no final da linha de produção e as bobinas passam por um período de 1 a 7 dias entre 30 e $35^{\circ} \mathrm{C}$, para maturação e então são armazenadas em câmara fria entre 17 e $20^{\circ} \mathrm{C}$ por 25 a 30 dias.

Peças fabricadas por este processo apresentam excelente estabilidade dimensional, elevadas propriedades mecânicas, boa resistência química e isolação elétrica. Devido à baixa contração apresentam ótimo acabamento superficial para posterior pintura.

$\mathrm{O}$ processo de moldagem consiste no corte de segmentos de manta para o processo SMC ou pesagem da massa para o processo BMC, que variam de acordo com a dimensão e massa desejadas para a peça, sendo colocadas em moldes para a prensagem, cujo processo pode variar de 1 a 4 minutos. O iniciador, que é sensível a temperatura é ativado pelo calor da prensagem que permite o início da polimerização da matriz polimérica. A peça após a cura é removida do molde e segue para posterior acabamento e pintura. Na FIG. 7 encontram-se exemplos de aplicações de peças moldadas em SMC e que utilizam adesivos estruturais na montagem de seus componentes (Tecnofibras, Produtos, 2008). 


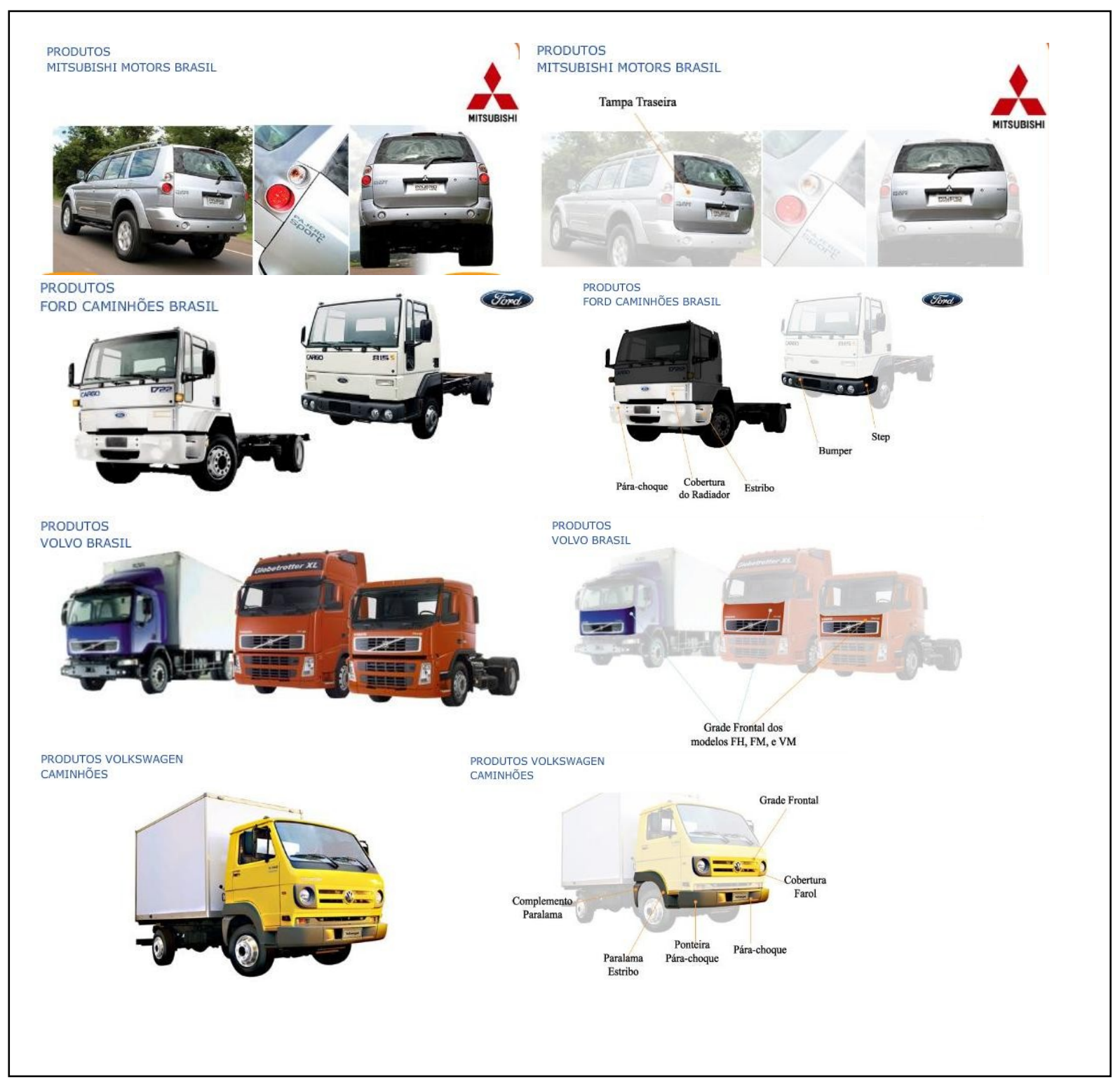

FIGURA 7 - Exemplos de peças moldadas em SMC (Tecnofibras, Produtos, 2008).

\subsection{Teorias da adesão}

As forças envolvidas na interação entre adesivo e substrato são as mesmas que estão presentes no interior do adesivo. Para compreender o que ocorre com um adesivo em uma junta, é necessário primeiro conhecer as forças que mantém os átomos e moléculas do adesivo unidas entre si (Petrie, 2000, p.49-93).

As forças adesivas e coesivas podem ser classificadas como primárias e secundárias. Forças primárias são subdivididas em forças covalentes, iônicas e metálicas. As forças covalentes são aquelas formadas por ligações covalentes, que apresentam energia de ligação 
entre 60 e $700 \mathrm{~kJ} \mathrm{~mol}^{-1}$, como por exemplo aquelas ocorridas em polímeros orgânicos ramificados. As ligações iônicas, de energia entre 600 e $1000 \mathrm{~kJ} \mathrm{~mol}^{-1}$ são aquelas formadas por ligações químicas iônicas como as presentes em cristais inorgânicos. As forças metálicas, de energia entre 100 e $350 \mathrm{~kJ} . \mathrm{mol}^{-1}$ correspondem às forças presentes entre os átomos de uma liga metálica.

Existem três tipos de forças secundárias, também chamadas de forças de van der Waals. São elas o dipolo induzido, dipolo permanente e ligações de hidrogênio (Payne, 1964, p. 9-17). As forças do tipo dipolo induzido, são também conhecidas como forças de London, tem energia de ligação entre 0,1 e $40 \mathrm{~kJ} \mathrm{~mol}^{-1}$ e as de dipolo permanente, tem energia entre $4 \mathrm{e}$ $20 \mathrm{~kJ} \cdot \mathrm{mol}^{-1}$ e estão presentes entre moléculas polares. Quando em uma molécula existem elementos muito eletronegativos, por exemplo $\mathrm{F}, \mathrm{O}$ e $\mathrm{N}$, ligados a átomos de hidrogênio a eletronegatividade destes átomos exerce uma maior atração do par eletrônico desta ligação polarizando a molécula, conseqüentemente esta molécula ao aproximar-se de outra que tenha elementos eletronegativos irá interagir com o hidrogênio formando uma ligação chamada de ligação de hidrogênio, esta ligação apresenta energia em torno de $40 \mathrm{~kJ} \cdot \mathrm{mol}^{-1}$.

Vale destacar que as forças primárias não estão presentes na maioria dos adesivos, sendo entretanto, uma necessidade nos adesivos de alto desempenho, como aqueles considerados estruturais. Para a maioria dos adesivos, as forças mais importantes relativas à adesão são as forças secundárias. A exata natureza destas forças e sua influência na resistência adesiva e coesiva são difíceis de determinar com precisão devido à sua complexidade.

As forças de interação entre o adesivo e o substrato podem ser medidas como o trabalho necessário para ocorrer uma separação das duas superfícies, que pode ser entre o adesivo e substrato, ou para que haja uma separação entre as moléculas de um material sólido (DUNOUY et al, 1919). Esta força é dependente das forças intermoleculares que existem no material e sobre o espaço intermolecular. Sendo às vezes chamada de energia de superfície $(\gamma)$.

Um método simples de medir a energia de superfície de um dado material sólido foi desenvolvido por Zisman, que propôs que a tensão crítica de superfície $\left(\gamma_{c}\right)$ de um sólido poderia ser estimada pela medida do ângulo de contato de uma série de líquidos, com tensão superficial $\left(\gamma_{\mathrm{LV}}\right)$ conhecida, formada por uma pequena gota do líquido sobre a superfície do sólido. Os dados dos cossenos das medidas de ângulo de contato são dispostos graficamente em função das tensões superficiais dos líquidos utilizados. A extrapolação da reta obtida até o cosseno igual a 1 , dará a tensão crítica de superfície $\left(\gamma_{c}\right)$, ou seja, seria a condição na qual um 
líquido de mesma tensão superficial formaria um ângulo $0^{\circ}$ com a superfície do sólido, que também pode ser definido como molhabilidade (HARKINGS et al, 1952).

A molhabilidade é um conceito que traduz a capacidade de um liquido molhar um sólido e estabelece que a tensão crítica de superfície do sólido deve no mínimo igual numericamente a tensão superficial do líquido (FOX, 1950).

O mecanismo de adesão, que corresponde à união entre o adesivo e o substrato, ainda não foi totalmente esclarecido. Muitas teorias foram formuladas, mas nenhuma delas foi capaz de esclarecer completamente o fenômeno. Algumas são mais adequadas a certos substratos e aplicações, outras são mais apropriadas a diferentes circunstâncias. Cada teoria tem sido assunto de estudos, questionamento e controvérsias. No entanto, cada uma delas emprega conceitos e informações que são aplicáveis na compreensão dos requisitos básicos de uma boa ligação entre adesivo e substrato (AHAGON, et al, 1975).

\subsubsection{Teoria da adsorção}

A teoria da adsorção estabelece que a adesão é resultado do contato molecular entre dois materiais e as forças de atração se desenvolvem na superfície. A adesão resulta da adsorção de moléculas do adesivo pelo substrato e as forças secundárias de van der Waals passam a atuar. Para estas forças se desenvolverem as respectivas superfícies não devem ser separadas mais do que 50 nanômetros de distância. Portanto, o adesivo deve ter um contato molecular muito próximo com a superfície do substrato. Para que este contato ocorra é preciso que haja uma boa molhabilidade. Esta molhabilidade ocorre quando o adesivo consegue fluir entre as irregularidades existentes na superfície do substrato, preenchendo desta forma os vales da superfície. Quando isto não ocorre pode haver o acúmulo de minúsculas bolhas de ar ao longo da interface dando origem a regiões e estresse (SCHNEBERGER et al 1970).

A molhabilidade é favorecida quando a energia de superfície do substrato é alta e a tensão superficial do líquido é baixa. Polímeros de baixa energia superficial molham facilmente substratos de alta energia, como por exemplo, metais. De forma inversa, substratos poliméricos de baixa energia são de difícil molhabilidade.

Os adesivos líquidos comuns molham rapidamente superfícies metálicas, cerâmicas e muitas superfícies poliméricas de alta energia, porém não são capazes de molhar superfícies poliméricas de baixa energia, como por exemplo, polietileno, polipropileno e polímeros fluorados. 
Como se nota para uma boa molhabilidade a tensão superficial do adesivo tem que ser menor do que a do substrato. Um exemplo disso é dado na FIG.8 (Petrie, 2000), onde se pode observar que o adesivo epóxi, que tem $\gamma$ da ordem de 47 dina. $\mathrm{cm}^{-1}$, é capaz de molhar apenas o alumínio, que tem $\gamma_{\mathrm{c}}$ da ordem de 500 dina. $\mathrm{cm}^{-1}$. Paralelamente a isto, quanto menor a $\gamma_{\mathrm{c}}$ do substrato maior será o ângulo de contato no caso dos substratos de policloreto de vinila, polietileno e polipropileno fluoroetileno.

Poder-se-ia esperar que polímeros de baixa energia como polietileno ou polifluoroetileno atuariam muito bem como adesivos sobre outras superfícies de difícil molhabilidade. De fato, eles são capazes de promover uma boa adesão, porém no caso do polietileno, o polímero apresenta muitos constituintes de baixa massa molar que formam uma camada fraca impedindo assim o seu uso.

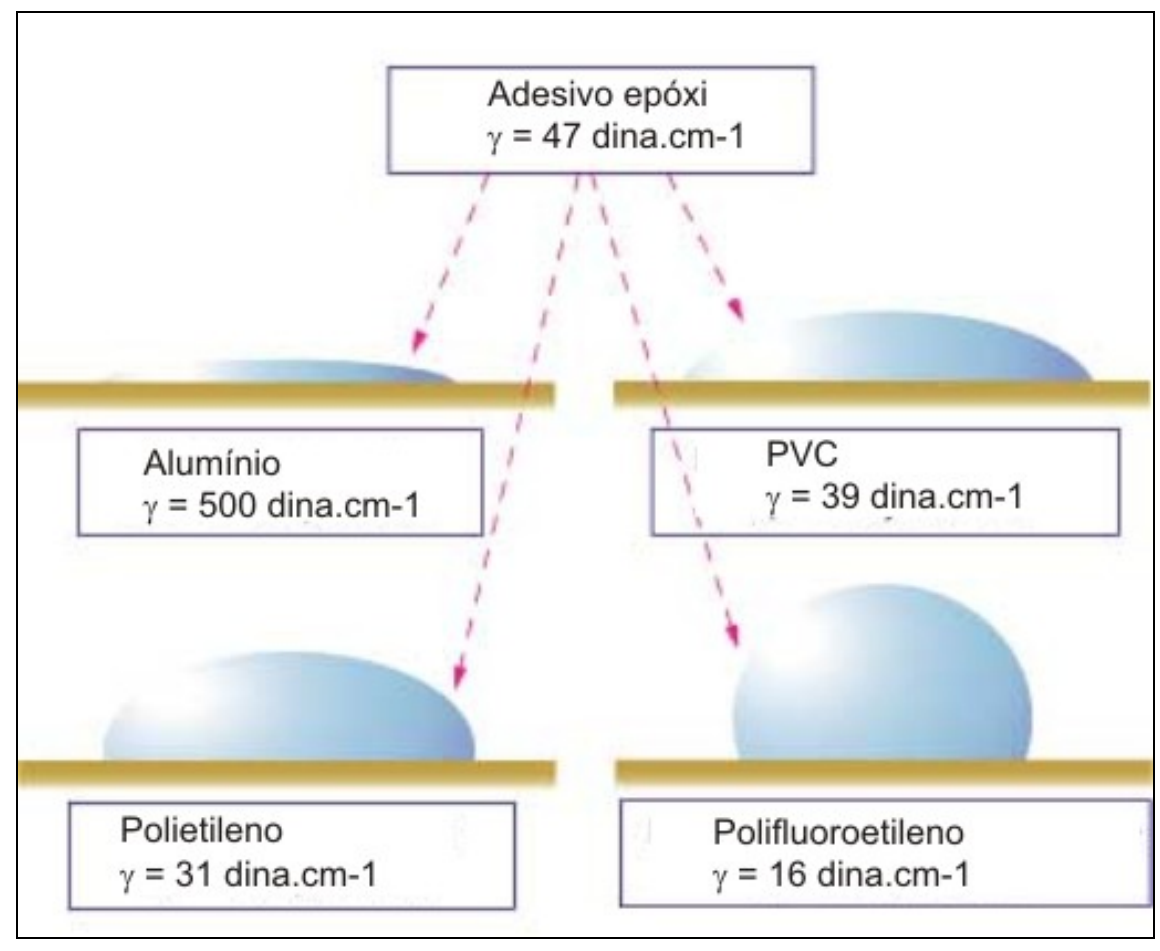

FIGURA 8 - Molhabilidade do adesivo epóxi (PETRIE, 2000, p. 51)

O polifluoroetileno não pode ser facilmente fundido ou solubilizado, então se torna difícil deixá-lo no estado fluido para molhar um substrato. Apesar destas dificuldades, o polietileno tem sido empregado como base em muitas formulações de hotmelt após remoção dos constituintes de baixa massa molar. Tem sido estudada a incorporação do 
politetrafluoretileno em formulações de adesivos epoxídicos, melhorando desta forma a sua capacidade de molhabilidade (LEE et al, 1988).

\subsubsection{Teoria mecânica}

A superfície de um material sólido nunca é totalmente lisa, mas consiste de uma combinação de picos e vales. Logo, é desejável que o adesivo seja capaz de preencher estas micro cavidades expulsando o ar presente no interior das mesmas.

Uma das formas de aumentar a adesão, considerando a rugosidade superficial, é pelo acréscimo da área total de contato entre adesivo e substrato. Outra forma é que após o preenchimento das cavidades o adesivo formará uma ancoragem mecânica com o substrato.

Há muitos casos onde as forças de adesão resultam de um trabalho conjunto na junta, Nestes casos, a resistência apresentada pela junta será uma soma da adesão ocorrida devido às interações primárias e secundárias, com o efeito da ancoragem mecânica ocorrido.

A ancoragem mecânica do adesivo parece ser o fator primordial no processo de colagem de substratos porosos. Frequentemente a ligação entre o adesivo e substrato não poroso melhora após o substrato receber um tratamento abrasivo. O efeito benéfico da rugosidade na superfície ocorre devido à ancoragem mecânica, formação de uma superfície mais limpa, formação de uma superfície mais reativa e aumento da área de contato (POCIUS, 1997).

\subsubsection{Teoria eletrostática}

Embora haja aplicações onde a eletrostática seja considerada, esta teoria não tem sido aplicada tanto quanto as teorias de adsorção e mecânica. A teoria eletrostática propõe que forças eletrostáticas ocorrem na forma de uma interface entre o adesivo e substrato, atuando como uma resistência a separação. Esta teoria pôde ser confirmada pela ocorrência de descargas elétricas quando um adesivo sofre despelamento do substrato. Esta teoria é aceita e aplicada principalmente para explicar a adesão de células biologias e também demonstrada na formação de filmes finos de polímeros sobre superfícies metálicas (LEE et al, 1988).. 


\subsubsection{Teoria da difusão}

O conceito fundamental da teoria da difusão é que o adesivo atua por interdifusão de moléculas do adesivo com o substrato. Ela é aplicável primordialmente quando ambos os materiais, adesivo e substrato, são de origem polimérica, possuem compatibilidade quanto à polaridade e apresentam tamanhos de cadeia apropriados para o movimento de difusão. Nos substratos termoplásticos a difusão ocorre por ação do solvente presente no adesivo ou por calor no caso dos termo fusíveis conhecidos como hotmelts. Outra possibilidade de difusão para termoplásticos é quando o substrato e adesivo são solúveis um no outro, porém isto é relativamente raro. Desta forma, a teoria da difusão pode ser aplicada apenas em um numero limitado de casos (BAIER et al, 1968).

\subsubsection{Teoria da camada de interface}

Quando uma falha ocorre em uma junta próximo à interface do adesivo e substrato, usualmente é chamada de falha coesiva, esta falha pode originar-se como consequência da ruptura de uma fina camada de baixa resistência na região da interface. Esta teoria sugere que esta camada fraca pode formar-se devido ao adesivo, substrato, ambiente ou uma combinação destas três, a qual pode ocorrer como decorrência de impurezas concentradas próximo à superfície da colagem, como por exemplo, desmoldantes, óleos, poeira e migração de plastificantes.

Antes da aplicação do adesivo, uma importante tarefa é a remoção da camada superficial mais fraca. O primeiro e mais comum material é o ar atmosférico. Esta remoção já foi descrita anteriormente e trata-se do processo de molhabilidade. Podem-se citar outros dois exemplos de camada de interface fraca. Um deles são os substratos de polietileno que usualmente apresentam constituintes de baixo peso molecular, igualmente distribuídos no polímero, inclusive na superfície. Estes constituintes irão formar a camada fraca de interface e comprometer a resistência da junta. Alguns substratos metálicos contém na sua superfície uma camada de óxidos metálicos, como óxido de alumínio, formam uma camada muito resistente e não comprometem a resistência da junta. No entanto óxidos de cobre presentes em algumas ligas de cobre formam uma camada fraca e necessitam ser removidos antes da aplicação do adesivo. 
Durante o período de solidificação do adesivo também pode ocorrer à formação de uma camada fraca na interface, como a que ocorre por exemplo em algumas superfícies metálicas onde a presença de titânio pode reagir com certos endurecedores. Por fim, durante a exposição do adesivo às condições de uso, uma camada fraca na interface também pode surgir devido à difusão de umidade ou outro líquido que possa ter contato com a junta. Plastificantes, solventes ou outros componentes de baixo peso molecular também podem migrar de dentro do corpo do adesivo ou do substrato para a interface prejudicando a resistência da junta (BIKERMAN, 1961).

\subsection{Superfície de contato}

$\mathrm{Na}$ literatura que aborda o assunto sobre adesivos (Cognard, 2006), o termo superfície de contato é usualmente definido como a porção do substrato que interage com o adesivo em relação à área e à profundidade da interação, no qual esta última, por exemplo, pode variar de uma ou duas camadas atômicas para um monocristal recém clivado, centenas de nanômetros para um alumínio anodizado quando usado um adesivo de baixa viscosidade ou até milímetros de profundidade em substratos porosos, como por exemplo na madeira (Petrie, 2000).

Ao microscópio é possível identificar as irregularidades na forma de vales e picos que não podem claramente ser percebidas a olho nu. A maior rugosidade aumenta a área de contato entre o adesivo e o substrato permitindo que ligações químicas e ou mecânicas ocorram. Isto garante uma melhor interação entre o adesivo e o substrato, aumentando a resistência mecânica da junta. No entanto, se a rugosidade for muito irregular, com profundidade exagerada e vales pontiagudos, além de espaços vazios, bolhas de ar ou outros defeitos, pode contribuir para uma concentração de esforço localizado, levando assim a uma redução da resistência mecânica da junta. Isto pode ocorrer dependendo de como o adesivo é capaz de molhar e penetrar nas irregularidades da superfície. Caso estas duas condições não sejam eficientes, pode ocorrer uma redução da resistência da junta (ADAM, 1941).

Frequentemente os elementos presentes na superfície do substrato são quimicamente diferentes daqueles que formam o substrato propriamente dito. Para metais e ligas metálicas, estas superfícies podem ser constituídas por óxidos, hidróxidos e gases absorvidos, enquanto que para materiais não metálicos pode haver a presença de umidade, migração de aditivos e outras substâncias adsorvidas. As substâncias presentes na superfície do substrato formam uma camada que pode estar aderida fraca ou fortemente ao mesmo, que podem apresentar uma 
força coesiva forte ou fraca, ou seja, ela pode ser difícil ou fácil de ser desfeita por algum esforço.

Estas propriedades da camada superficial são muito importantes para o desempenho do adesivo por três razões principais. Primeiramente o adesivo deve ter boa interação com a camada superficial, seja por atração eletrostática ou por reação química. Em segundo lugar, esta camada deve estar bem aderida ao substrato, pois caso contrário ocorrerá uma falha adesiva entre a camada superficial e o interior do substrato e por último, esta camada não pode ser facilmente desfeita, causando uma falha coesiva (Cognard, 2006).

A contaminação da superfície do substrato pode comprometer a atuação do adesivo. Basta uma simples camada molecular de contaminante, como por exemplo, óleos, graxas, impressões digitais e desmoldantes, para impedir que o adesivo tenha uma boa interação com o substrato, ou seja, o adesivo tentará interagir primeiramente com o contaminante ao invés de interagir com o substrato.

Os constituintes que estão presentes na superfície do substrato podem ser diferentes quanto à forma estrutural e composição química daqueles presentes no corpo do substrato. Esta diferença pode ser devido à adsorção de contaminantes do ambiente ou por segregação de constituintes internos para superfície durante o processamento do material. Os contaminantes externos e constituintes internos segregados nem sempre são distribuídos homogeneamente na superfície e esta falta de homogeneidade pode gerar áreas de descontinuidades da colagem e concentração de esforço na junta (SHARPE et al, 1990).

Superfícies metálicas, como aço e ligas de alumínio, podem apresentar uma série de regiões de composição química diferente e não tendo o limites claramente entre elas, como visto para metais na FIG. 9 (Specialchem4adhesive, 2006). A camada contaminante também dependerá de como o metal foi estocado e manuseado, podendo existir inclusive contaminantes propositalmente adicionados para prevenir corrosão, como óleos e outros inibidores, que também devem ser removidos. 


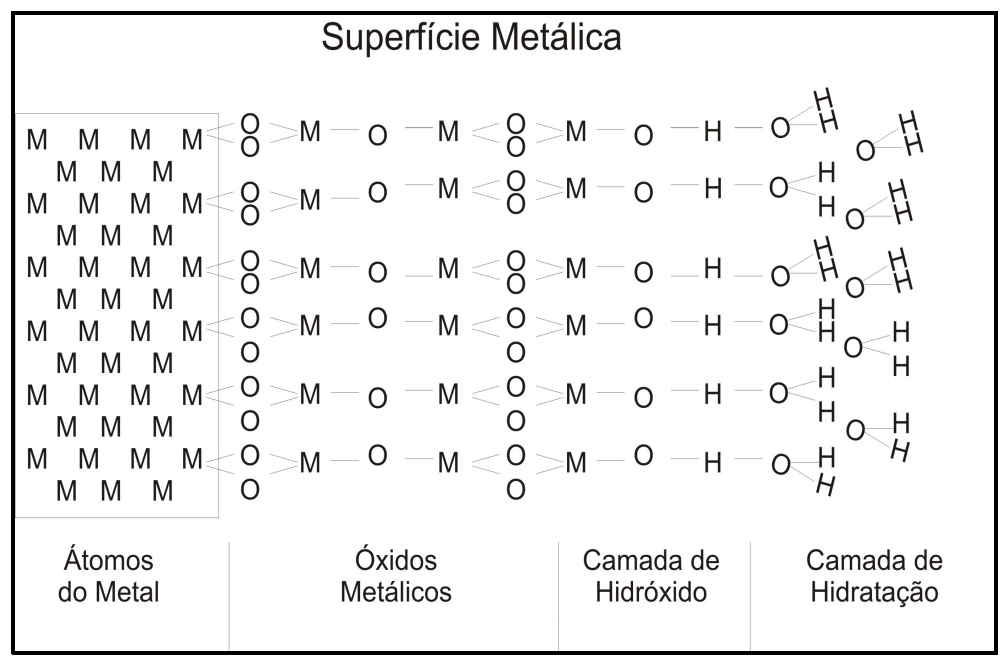

FIGURA 9 - Camadas da superfície metálica (Specialchem4adhesive, 2006).

O tipo de tratamento da superfície depende do tipo de substrato, do adesivo utilizado e da resistência mecânica pretendida. Algumas vezes utiliza-se o substrato para contato direto com o adesivo sem nenhum prévio tratamento superficial, pois a superfície já é capaz de interagir de modo compatível com o adesivo. Outras vezes, entretanto, dependendo da natureza da aplicação e do substrato, poderá ser necessário uso de abrasão mecânica, primer ou métodos de tratamento químico para ativar a superfície. Há casos ainda que por falta de conhecimento da composição da superfície, é preciso remover toda esta camada e conduzir um tratamento apropriado.

\subsection{Tratamento de superfície}

A resistência obtida por uma junta colada dependerá não somente da resistência coesiva do adesivo e do substrato, mas também do grau de interação entre eles. A interface de adesão entre um adesivo e um substrato é formada por uma camada de dimensões muitas vezes moleculares e a resistência que a junta apresentará pode ser reduzida pela presença de contaminantes na superfície. (Petrie, 2000, p. 197-250). Para se obter uma ótima adesão, a superfície do substrato deve estar limpa ou convertida para uma condição apropriada antes do processo de colagem e este é o propósito do tratamento de superfície. 
Não há um método único de tratamento de superfície que se aplique a todos os tipos de substratos. Assim, a escolha do tratamento mais adequado é trabalho de uma avaliação prática para um dado conjunto de adesivo e substrato. Esta escolha depende de fatores como natureza do substrato e suas condições, o tipo de adesivo escolhido, esforço requerido da junta, condições de exposição da junta, tempo de uso pretendido da junta, custos de processos e recursos disponíveis (Payne, 1964, p. 1017-1036).

A composição da superfície de um substrato é determinada pelo histórico do material. Metais são em geral tratados termicamente, anodizados, recobertos com óleo protetor, protegidos com camadas finas de polímeros entre outras condições. Plásticos podem estar contaminados com agentes desmoldantes, plastificantes ou apresentarem uma camada superficial mais fraca. Compósitos geralmente apresentam resíduos de desmoldantes aplicados ao molde e plastificantes que migram para superfície no processo de cura (Cognard, 2006).

O simples tratamento de limpeza por ação de solventes ou métodos de abrasão remove contaminantes da superfície que poderiam impedir o adesivo de molhar o substrato (Baker, 1992).

Há tratamentos de superfície que são mais eficientes e melhoram o processo pelo qual o adesivo atua. Por exemplo, tratamentos químicos modificam a superfície física e quimicamente, enquanto que abrasão mecânica apenas promove aumento da superfície de contato e pontos de ancoragem mecânica no substrato para o contato com o adesivo (Shields, 1976, p. 219-244). Dependendo do tipo de material e do tratamento das superfícies, estes podem receber o adesivo após várias horas ou, em alguns casos em apenas alguns minutos.

Quando elevadas resistências das juntas coladas são esperadas, o tratamento deve ser mais profundo. Por exemplo, os adesivos estruturais para colagem de juntas alumínio que serão expostas a condições extremas de intempéries e temperaturas, requerem, além da limpeza com solvente e abrasão, um tratamento mais complexo que pode incluir o uso de ácidos e agentes oxidantes. O mesmo não seria necessário caso a resistência esperada não fosse tão elevada e fossem utilizados adesivos não estruturais, onde apenas uma simples limpeza com solvente já seria satisfatório. Métodos mecânicos são adequados quando as partes a serem coladas são de pequenas dimensões ou quando o processo não permite uso de métodos químicos e tratamentos típicos de superfície que incluem abrasão e limpeza com solvente (Payne, 1964, p. 649-657). 
Tratamentos químicos são mais adequados quando o volume de produção viabiliza a instalação dos equipamentos apropriados e podem variar em função dos substratos e adesivos utilizados. Normalmente envolvem uma etapa de limpeza da superfície seguida por uma ou mais etapas em banhos contendo soluções de reagentes apropriados, aquecidos ou não, seguidos por lavagem e secagem.

Tratamentos mecânicos e químicos vêm sendo aos poucos substituídos por métodos físicos como tratamento com chama, bombardeamento iônico e descarga elétrica. Estas técnicas têm se mostrado eficientes na preparação de plásticos de difícil aderência, como por exemplo, polietileno, polipropileno e politetrafluoroetileno. A modificação da superfície que ocorre a partir destes métodos ainda não é totalmente conhecida. Há evidências que métodos elétricos modificam a estrutura molecular do substrato e afetam a oxidação da superfície.

\subsubsection{Metais}

A preparação da superfície de um metal é de suma importância para a integridade e durabilidade da junta metálica sujeita a elevadas tensões e severas condições de uso. O tratamento apropriado da superfície para formação da junta merece de uma avaliação criteriosa, principalmente em aplicações estruturais, onde os níveis de esforço são mais elevados (Konate, 1994).

Após um tratamento químico, a superfície metálica torna-se altamente ativa e pode facilmente atrair contaminantes do ar como poeira e umidade. Portanto, é necessário efetuar a colagem o mais rápido possível após oeste tipo de tratamento.

As superfícies metálicas invariavelmente estão contaminadas com óleos e graxas e uma etapa inicial de limpeza com um desengraxante é essencial. Podem ser usados solventes ou a passagem de vapor do solvente, o que é mais efetivo. Este desengraxe deve ser profundo e os contaminantes não podem ser depositados novamente na superfície após a evaporação do solvente e um enxague final sempre é recomendável. Em geral é utilizado para o desengraxe o tricloroetileno ou o percloroetileno (Mats, 1988).

Um teste simples pode ser feito para verificar a eficiência do desengraxe. Para isso, basta apenas aplicar água sobre a superfície metálica. Caso o desengraxe tenha sido bem feito, haverá formação de um filme uniforme, isento de bolhas ou descontinuidades. Bolhas são um indicativo de contaminação. Soluções alcalinas ou detergentes são usados após limpeza com solvente para remoção de poeira e resíduos inorgânicos (Petrie, 2000). 
Métodos mecânicos de abrasão são utilizados onde há presença de oxidação superficial e são utilizados para retirar a camada de óxido e expor o metal para posterior tratamento ou mesmo para colagem direta. No caso do alumínio, a formação do óxido após abrasão é rápida, porém para metais como aço inox ou titânio isto não representa um problema. O processo dependerá do sistema abrasivo utilizado, como por exemplo, o emprego de lixamento manual, de lixadeiras mecanizadas e de lixadeiras pneumáticas, porém o processo é de difícil controle se comparado aos métodos químicos. Outro aspecto da ação mecânica é que ele possibilita a formação de juntas menos resistentes do que as formadas por superfícies tratadas quimicamente, pois a formação de rugosidade pode levar a penetração de água ou solvente sendo, em alguns casos, não recomendada (Sheppard et al 1998).

O tamanho e a natureza do abrasivo também são aspectos importantes. Para cada metal ou liga há um tipo de material abrasivo e uma faixa de tamanho mais adequado. É importante o desengraxe antes da abrasão, pelos motivos expostos anteriormente, e também após abrasão para remoção de contaminantes oriundos dos materiais abrasivos utilizados, que podem enfraquecer a formação da junta (Cognard, 2006).

Métodos químicos e eletroquímicos são preferíveis aos mecânicos onde controle da qualidade e reprodutibilidade são necessários, além do que podem promover a formação de uma camada quimicamente resistente que aumentará a resistência da junta quando em condições de exposição. O tratamento envolve imersão em soluções diluídas ou concentradas ácidas ou alcalinas a temperatura ambiente ou elevada. Após a camada de óxido ser removida, o metal é geralmente tratado sob condições controladas com soluções oxidantes, como por exemplo, soluções ácidas de dicromato para produzirem camadas de óxido com estrutura e espessura controladas (Dodiuk, 1988)

A qualidade da água utilizada nestes processos para metais deve ser considerada. $\mathrm{O}$ enxague final deve ser feito com água o mais purificada possível, que depende do tipo de aplicação e o sistema adesivo a ser utilizado. Adesivos a base de resinas epoxídicas têm menor resistência a ácidos do que alguns outros adesivos, que por sua vez são mais tolerantes a alcalinidade e presença de cloretos do que adesivos nitro-fenólicos. Um exemplo é aquele que se encontra na indústria aeroespacial onde o alumínio e suas ligas têm sido extensivamente investigados, pois o tratamento com soluções de ácido sulfúrico e dicromato de sódio produz uma camada aderente de óxido hidratada, $\alpha-\mathrm{Al}_{2} \mathrm{O}_{3} \cdot 3 \mathrm{H}_{2} \mathrm{O}$, em temperaturas abaixo de $60^{\circ} \mathrm{C}$. 
Acima desta temperatura, há uma mudança na estrutura do óxido para a forma $\beta$ $\mathrm{Al}_{2} \mathrm{O}_{3} \cdot \mathrm{H}_{2} \mathrm{O}$. $\mathrm{O}$ desempenho do adesivo epóxi sobre a superfície da $\alpha$-alumina é inferior aquele obtido na superfície da $\beta$-alumina. Portanto, pequenas alterações no tratamento químico podem originar interferências indesejáveis na resistência final da junta formada por metais (Petrie, 2000).

\subsubsection{Plásticos}

Os plásticos são descritos como termoplásticos ou termorígidos de acordo com seu comportamento ao serem aquecidos, em contato com solventes ou em condições de estresse. Os plásticos termofixos são infusíveis, não escorrem com aquecimento, são insolúveis em solventes, embora possam absorver alguns solventes. Tais propriedades impedem que sejam formadas juntas entre estes materiais por uso de calor ou ataque com solventes, sendo possível apenas pelo uso de adesivos. Já os termoplásticos podem ser colados por ação do calor ou por dissolução com solventes (Cognard, 2006).

Um pré-tratamento é fundamental para muitos termoplásticos de difícil adesão. Além da rugosidade obtida por abrasão que possibilita uma fixação mecânica, o tratamento da superfície concentra-se basicamente na remoção de agentes desmoldantes e na formação de uma superfície de alta energia com grande afinidade para adesivos polares (Kaplan, 1991)

Os agentes desmoldantes presentes na superfície de materiais poliméricos reduzem o contato interfacial entre o adesivo e o substrato, prejudicando assim a aderência. Entre eles encontram-se substâncias aplicadas aos moldes para desmoldagem das peças, além de óleos e graxas e plastificantes que podem migrar para a superfície. Usados principalmente em

plásticos flexíveis, estes agentes desmoldantes podem formar uma camada na superfície do substrato e prejudicar a adesão (Baldan, 2004)

A remoção destes contaminantes pode ser feita de várias formas, como por ação de solventes, abrasão ou tratamento brando com calor. Em geral é desaconselhável a adesão de plásticos que contenham estearato como desmoldante, pois podem ocorrer migrações posteriores para a superfície que danificarão a colagem (Stewart, 2005). Apesar disto, alguns adesivos resistem bem à migração de desmoldantes internos, como por exemplo os adesivos poliuretânicos e nitro-fenólicos. Substratos olefínicos possuem energia superficial mais baixa do que substratos hidrofílicos como metais e vidro, por isso o adesivo fica impedido de molhar 
a superfície do substrato adequadamente e como consequência a aderência fica comprometida (Petrie, 2000).

Superfícies não tratadas, como polietileno e plásticos fluorados, apresentam uma dificuldade particular ainda maior, uma vez que suas energias de superfícies encontram-se abaixo da energia dos solventes e dos adesivos. Portanto, tratamentos químicos e físicos são necessários para obter uma superfície de alta energia para promover a adesão (Nie, 1999).

A modificação da superfície de um substrato plástico pode ser feita por meio de abrasão, pelo uso de reagentes que modificam a superfície por ataque químico, formando uma camada de composição química diferente do seu interior, ou por bombardeamento com descarga de íons gasosos para formar uma camada de oxidada apropriada para o contato com o adesivo (Bienk, 1997).

Plásticos expandidos são suficientemente porosos para permitir uma fácil absorção do adesivo e raramente requerem pré-tratamento. A modificação das matérias primas dos plásticos pela inserção de pigmentos, cargas minerais e plastificantes altera significantemente a interação com o adesivo, consequentemente um tratamento superficial que é eficiente para um tipo de polímero pode não ser o melhor para o mesmo material na forma modificada. $\mathrm{O}$ usuário deve valer-se do conhecimento de vários processos de tratamento superficial e métodos de testes de juntas para ter certeza da eficácia da colagem em uma junta ao longo do tempo em que estiver exposta (Cognard, 2006).

\subsubsection{Compósitos Poliméricos}

Os materiais compósitos caracterizam-se pela combinação macroscópica de dois ou mais materiais distintos que podem ser fisicamente identificados e exibem uma interface bem definida entre eles. Como são usados por suas elevadas propriedades mecânicas, esta definição pode ser restringida para incluir somente aqueles materiais que contém um reforço, como

fibras, sustentado por uma matriz que pode ser polimérica, cerâmica ou metálica. (ASM, 1987).

A preparação de superfície para processos de colagem de compósitos dependerá da composição entre matriz polimérica, do reforço e de que forma estes componentes estão distribuídos na superfície que terá contato com o adesivo. Por exemplo, para um compósito que apresente alto teor de matriz polimérica deve-se primeiramente avaliar a compatibilidade 
entre esta matriz e o adesivo, levando em consideração a mesma abordagem descrita anteriormente para os plásticos. Nestes casos, onde a matriz polimérica esteja presente em maior porcentagem, esta avaliação já é suficiente. Quando o teor de reforço for mais significativo, a aderência sobre ele deve ser considerada (Bienk et al, 1997).

\subsubsection{Fibras}

Produtos fibrosos são formados por uma vasta gama de materiais orgânicos e inorgânicos e são usados como filamentos na produção de tecidos, plásticos laminados ou compósitos poliméricos. Para muitas aplicações a adesão mecânica obtida pela saturação do adesivo que envolve a fibra já seria suficiente, porém em certos tecidos pode ocorrer uma falha adesiva quando submetidos a esforço mecânico devido à baixa adesão entre o adesivo e a fibra, sendo necessários tratamentos químicos ou físicos adequados para reforçar a aderência na interface do adesivo e fibra (Grignon, et al, 1986).

Fibras naturais, como as celulósicas e de algodão, possuem suficientes sítios polares para interagir satisfatoriamente com os adesivos, enquanto que fibras sintéticas, como poliacrilonitrila, poliamida, poliéster e poliolefinas apresentam baixa energia de superfície, o que pode limitar a adesão.

A superfície acabada de muitos materiais sintéticos é irregular e não favorece a adesão. Portanto, um tratamento químico se faz necessário sempre que o desempenho requerido for crítico. Compósitos poliméricos geralmente apresentam uma fina camada de um prétratamento sobre as fibras para promover a aderência da matriz polimérica. Especialmente no caso de fibras de vidro, há tratamentos especiais a base de clorosilanos para o tipo de matriz a ser utilizada. Fibras de carbono obtidas pela oxidação e carbonização de filamentos orgânicos são tratadas com soluções de ácido nítrico $(60-70 \%)$ seguido de imediato contato com polímero adesivo para promover uma adesão interfacial (Petrie, 2000).

\subsubsection{Materiais Inorgânicos}

Cerâmicas e vidros geralmente não apresentam camadas superficiais frágeis que requeiram modificação superficial. Para uma limpeza inicial, o tratamento com solução ácida de cromato a $60^{\circ} \mathrm{C}$ apresenta melhores resultados na remoção de contaminantes do que o uso de solventes. Alternativamente pode-se utilizar uma solução de trióxido de cromo. 
Vidros para aplicações ópticas ou eletrônicas podem requerer tratamentos especiais . A Imprimação de vidro com clorosilano aumenta consideravelmente a aderência. Este tratamento é largamente usado para fibras de vidro usadas na moldagem de compósitos poliméricos. Para outros materiais inorgânicos ou minerais, apenas a limpeza com solvente é suficiente. Silicatos minerais como quartzo, pedras e mica podem ser tratados pelo mesmo processo do vidro (Cognard, 2006).

\subsubsection{Madeira}

Geralmente estas superfícies estão contaminadas com sujeira e poeira, além de óleos ou resinas que exudam da própria madeira e que tem um efeito adverso na molhabilidade do adesivo. Quando cortadas e lixadas aumentam a área de contato com o adesivo, porém nem sempre são adequadas para colagens de alta resistência devido ao pó formado que pode ficar contido nas rugosidades. Outro fator é a umidade da madeira que pode interferir em alguns adesivos, sendo que esta deve estar entre 8 a $12 \%$ para a maioria dos adesivos (Cognard, 2006).

\subsection{Projeto de junta}

A resistência mecânica que uma determinada junta poderá apresentar depende das propriedades mecânicas dos substratos e adesivos empregados, da extensão do contato interfacial entre o substrato e o adesivo, da espessura de adesivo e do projeto da junta (Quini, 2005). Este último particularmente não tem sido adequadamente considerado e muitas vezes tem sido a causa de insucessos no uso de adesivos em substituição aos sistemas convencionais de união (CHASTAIN, 1974). Pode-se encontrar uma descrição mais detalhada sobre projeto de junta no Anexo B. Muitos estudos a respeito tem sido desenvolvidos para maximizar o desempenho das juntas, um deles feito por Broughton et al (2007) obteve um aumento de 40\% da resistência ao cisalhamento apenas modificando o projeto da junta. 


\section{Pesquisa bibliográfica}

É possível encontrar na literatura diversos trabalhos sobre adesivos estruturais. A seguir, serão apresentados alguns dos trabalhos mais relevantes que serviram como base para o presente estudo.

Bartholomeuz et al (1999) avaliaram a distribuição do stress ao longo da camada de adesivo epóxi por meio de análise de elementos finitos mostrando que o esforço máximo ocorre na região central durante um esforço de cisalhamento.

As propriedades mecânicas de juntas formadas por compósitos laminados de matriz polimérica éster vinílica reforçada com fibras de vidro, unidas por adesivo estrutural epóxi, foram estudadas por Taib et al (2006). Os autores analisaram o efeito da espessura do adesivo, defeitos na camada adesiva, umidade, rigidez do substrato através de testes de cisalhamento. Neste estudo foram utilizados quatro tipos de juntas, onde foi observada que a diminuição da resistência ao cisalhamento com o aumento da espessura do adesivo e também na presença de umidade. Intencionalmente a presença de área não colada no interior da junta não afetou a resistência à ruptura. A rigidez do substrato afetou a forma de ruptura onde nas juntas de maior rigidez ocorreu falha do substrato e nas de menor rigidez ocorreu falha no adesivo.

Adderley et al (1998) apresentam resultados de resistência ao cisalhamento de juntas de substratos metálicos colados com adesivos epoxídicos e os efeitos de diferentes tipos de preparação de superfície por abrasão, efeito de névoa salina e efeito de temperatura no momento do ensaio.

Parker et al (1994) apresentaram resultados de cisalhamento, tração e clivagem de juntas de compósito e metal coladas com adesivo epóxi. Foi avaliado o efeito do substrato sem abrasão, com abrasão mecânica e manual, efeitos de exposição à umidade, como também o efeito de diferentes contaminantes na superfície como politetrafluoroetileno, silicone e poliamida.

Balkova et al (2002) apresentaram resultados de cisalhamento em substratos pultrudados de poliéster reforçado com fibra de vidro, colados com adesivo epóxi, após exposição a diferentes condições durante um ano. Comparou-se o efeito da imersão em água e a exposição a $60^{\circ} \mathrm{C}$ com corpos de prova semelhantes, expostos a temperatura ambiente.

Kovakevik et al (1989) conduziram um estudo da degradação de poliuretano termoplástico submetido ao intemperismo avaliado por espectroscopia na região do 
infravermelho (IR), ressonância magnética nuclear de hidrogênio (NMR), microscopia eletrônica de varredura (MEV) e tensão de ruptura do filme de adesivo.

Strobech et al (1990) estudaram diversos tipos de poliuretanos mono e bicomponente avaliação de tempo de cura, viscosidade, dureza e tensão de ruptura.

Malucellia et al (2005) utilizaram diversas técnicas como medidas de ângulo de contato, análise termogravimétrica diferencial, calorimetria diferencial exploratória, avaliação da resistência ao cisalhamento de juntas coladas com adesivo poliuretano monocomponente base poliéter em substratos de polioxipropileno, polipropileno e alumínio. Os pesquisadores utilizaram métodos de tratamento de superfície como oxidação da superfície e promotores de adesão para melhorar a aderência. Resultados do estudo indicaram haver correlação entre a molhabilidade e aderência, sendo que nos substratos de maior ângulo de contato, logo menor molhabilidade, a aderência medida pela resistência ao cisalhamento foi significativamente menor do que nos de maior molhabilidade, também observaram a cinética da reação e comportamento térmico do adesivo.

Boerio et al (1981) estudaram por meio de espectroscopia vibracional de reflexão e absorção na região do infravermelho, a formação de um filme de organosilano sobre a superfície metálica de ferro e relacionaram com a resistência ao cisalhamento de juntas coladas com e sem este filme utilizando um adesivo de composição epoxídica, neste estudo observaram aumento de $25 \%$ na resistência ao cisalhamento.

Fernlund et al (1991) estudaram como a fratura de juntas adesivas de alumínio com adesivo epóxi está relacionada com a elasticidade dos materiais empregados, ao esforço aplicado, tipo de junta, espessura do adesivo e pré-fratura do adesivo. Observaram também que a força necessária para propagar a fratura em juntas pré-fraturadas foi menor do que em juntas inteiras.

Lees (1986) apresenta um trabalho sobre a formação de juntas entre compósitos e metais coladas estruturalmente com adesivos epóxis e metacrilato. A relação entre estes substratos e a variedade de tipos de adesivos estruturais também é discutida levando-se em consideração principalmente fatores como ductibilidade, fragilidade e resistência dos adesivos. Aspectos teóricos sobre distribuição do esforço na junta também são discutidos em função do desenho da junta.

Sugama et al (1998) demonstraram o aumento da durabilidade de juntas de alumínio coladas com adesivos poliuretanos pela imprimação da superfície oxidada com soluções de 
polímeros quando expostas a soluções alcalinas a quente. Também mostrou que em alguns casos ocorre hidrólise na interface composta por óxido de alumínio e primer a base de silanos.

Shanahan et al (1998) estudaram juntas de alumínio e aço zincado coladas com adesivo epóxi submetidas a esforços de torção sob condições de temperatura e alta umidade relativa, avaliando por espectroscopia eletrônica Auger e espectroscopia fotoeletrônica de raio-X a superfície após o ensaio mecânico e relacionando o resultado mecânico com a superfície de adesão.

Sheppard et al (1998) estudaram modos de falha de juntas formadas por alumínio e compósitos epóxi/fibra de grafite, coladas com adesivos estruturais e propuseram uma comparação entre resultados experimentais e modelamento por elementos finitos, conseguindo uma boa aproximação.

Métodos de caracterização não destrutivos tem sido desenvolvidos para avaliar a linha de colagem em juntas formadas por compósitos. Mylavarapu et al (2006) estudaram a existência de defeitos e descontinuidades em juntas de compósito de epóxi com fibras de carbono, colados por adesivo estrutural epóxi, por meio de imagem ultrassônica e puderam estabelecer parâmetros característicos para cada defeito. Outro trabalho importante nesta área tem sido desenvolvido por Singher (1997) que apresenta resultados de diversos experimentos de colagens em diversas espessuras analisados por métodos ultrassônicos que permitiram a determinação de imperfeições na área de colagem.

Os estudos de adesivos estruturais encontrados na literatura estão voltados principalmente para adesivos epóxis e metacrilatos, na união de metais e alguns plásticos. Em menor número há trabalhos que abordam o uso de substratos compósitos de poliéster/fibra de vidro. Desta forma o presente trabalho contribuirá para a área de estudo de adesivos pelo seu caráter inédito e pouco explorado, uma vez que ele pretende não apenas investigar o comportamento mecânico de juntas formadas por compósitos, metais e plásticos, além da própria interação entre um adesivo estrutural uretânico e substratos. 


\section{Materiais empregados}

\subsection{Adesivo uretânico}

Foi utilizado o adesivo uretânico bicomponente Masterpur Estrutural 300, composto por um componente A a base de poliol e outro componente B a base de isocianatos. A proporção de mistura em peso é de 100 partes de componente A para 25 partes de componente B. Na TAB. 1 podem ser encontradas as propriedades físico-químicas dos componentes que formam o adesivo. O Anexo $\mathrm{C}$ apresenta informações complementares sobre a aplicação deste adesivo.

Este adesivo estrutural foi desenvolvido pelo autor nas dependências da empresa Urepol Polímeros - Masterpol Adesivos.

TABELA 1 - Propriedades físico - químicas do adesivo Masterpur Estrutural 300

\begin{tabular}{lc}
\hline & Componente A \\
\hline Proporção na mistura & 100 partes \\
Composição básica & Polióis, cargas minerais e aditivos \\
Aspecto & Pasta viscosa branca \\
Teor de sólidos & $99,5-100 \%$ \\
Densidade a $25^{\circ} \mathrm{C}$ & $1,20-1,30 \mathrm{~g} \cdot \mathrm{cm}^{-3}$ \\
Consistência & $4,2-6,7 \mathrm{~cm}(2 \mathrm{~g} / 2 \mathrm{~min} / 2 \mathrm{~kg})$ \\
\hline & Componente B \\
\hline Proporção na mistura & 25 partes \\
Composição básica & Isocianatos polifuncionais e aditivos \\
Aspecto & Pasta viscosa marrom \\
Teor de sólidos & $99,5-100 \%$ \\
Densidade a $25^{\circ} \mathrm{C}$ & $1,05-1,10 \mathrm{~g} \cdot \mathrm{cm}^{-3}$ \\
\hline & Mistura \\
\hline Tempo de gel a $25^{\circ} \mathrm{C}$ & $3-5$ minutos \\
Tempo aberto a $25^{\circ} \mathrm{C}$ & $6-8$ minutos \\
\hline
\end{tabular}

A medida de consistência apresentada na TAB.1 é uma medida da viscosidade feita por um método muito simples, consiste em pesar $2 \mathrm{~g}$ de produto sobre uma placa de vidro de $50 \times 50 \mathrm{~mm}$, coloca-se outra placa de vidro de mesmas dimensões e sobre elas um peso de $2 \mathrm{~kg}$. Após 2 min retira-se o peso e mede-se o tamanho da circunferência, que deve estar entre 4,2 e $6,7 \mathrm{~cm}$. Entende-se por gel time o tempo útil após a mistura dos dois componentes no qual o operador pode manusear o adesivo e tempo aberto é o tempo após a mistura no qual o operador pode fazer a união das partes da junta. 
Para fabricação dos corpos de prova, o adesivo foi aplicado utilizando um equipamento pneumático que realiza a dosagem e mistura dos dois componentes do adesivo, conforme ilustrado na FIG. 10 abaixo. Este equipamento dispõe de um sistema de alimentação dos componentes do adesivo separadamente em tambores metálicos de $65 \mathrm{~kg}$ para o componente A e $55 \mathrm{~kg}$ para o componente B. O adesivo é transferido por auxílio de pistões pneumáticos para uma unidade de dosagem volumétrica. Nesta unidade, o adesivo é dosado na proporção volumétrica de 100 partes de componente A para 27 partes de componente B. Esta proporção em volume é diferente da proporção em peso (100:25) devido à diferença de densidade entre os dois componentes do adesivo.

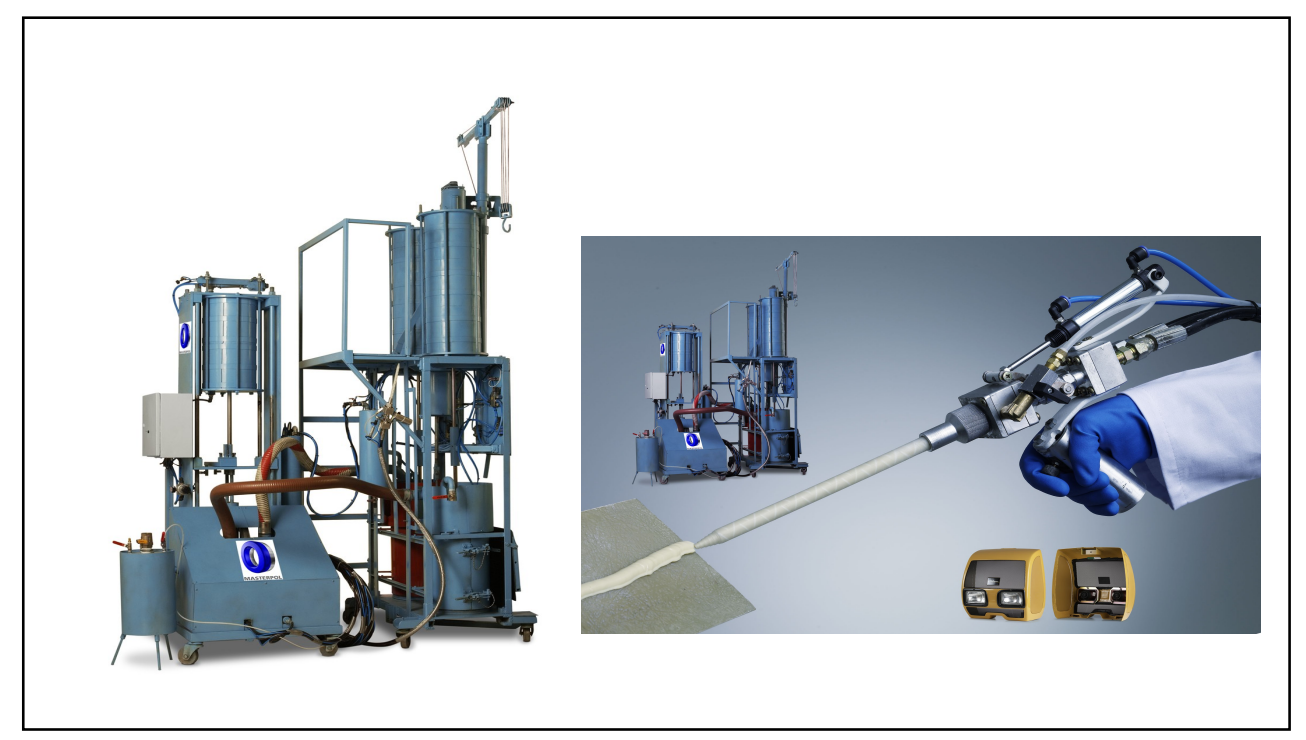

FIGURA 10 - Equipamento dosador e aplicador de adesivo (Masterpol Adesivos, 2011).

Uma vez dosado, os dois componentes seguem por mangueiras individuais até a pistola, onde eles encontram-se dentro de um bico misturador estático tipo 10x24, ilustrado na FIG. 11. Este bico é composto por um tubo plástico de $10 \mathrm{~mm}$ de diâmetro interno e $250 \mathrm{~mm}$ de comprimento que contém 24 elementos de mistura. Estes elementos são os responsáveis por realizar a mistura e a correta homogeneização do adesivo. Sabe-se por experiência que para este adesivo são necessários, no mínimo, 20 elementos de mistura devido às propriedades de viscosidade e tixotropia (Liquid Control Corp, 1996). Após a aplicação um procedimento de limpeza é feito para remover o excesso do adesivo misturado que pode reagir e provocar o entupimento do bico. Para isto, uma válvula na pistola é aberta fazendo-se passar uma solução 
de $70 \%$ de álcool isopropílico e 30\% de acetona sob pressão, que limpa os excessos de adesivo.

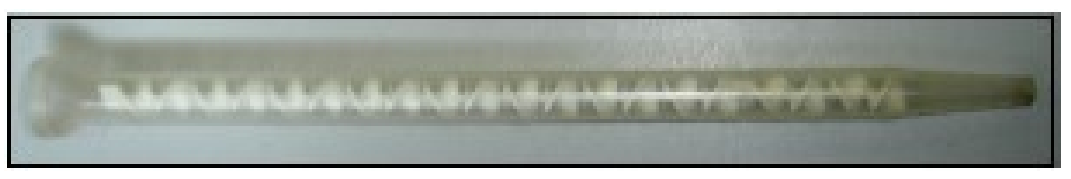

FIGURA 11 - Bico misturador estático 10x24.

O adesivo uretânico tem sido utilizado comercialmente em colagem de peças em compósito poliéster/fibra de vidro em diversas aplicações, como por exemplo, peças para tratores, caminhões, ônibus e embarcações de lazer.

\subsection{Substratos}

\subsubsection{Metais}

$\mathrm{O}$ aço carbono tem sido bastante utilizado como reforço estrutural em peças de compósito de uso automotivo devido às suas boas propriedades mecânicas e custo relativamente baixo. Porém para elevar a resistência à corrosão, muitos tratamentos de superfície têm sido avaliados e o processo de zincagem e cromação preto é um dos que apresenta o melhor desempenho nas condições propostos pelo presente estudo, como névoa salina, por exemplo. Estas condições incluem variações de temperatura e ambientes quimicamente agressivos.

Foram utilizadas chapas metálicas de aço carbono zincado e cromado preto (ACZCP) fornecidas pela empresa Tecnofibras S.A. Estas chapas possuem $2 \mathrm{~mm}$ de espessura e foram cortadas nas dimensões de $100 \mathrm{~mm}$ de comprimento por $25 \mathrm{~mm}$ de largura. O processo de galvanização zincagem e cromação preto foi feito conforme procedimentos da empresa Alpha Galvano-Química Brasileira Ltda. 


\subsubsection{Plásticos}

ABS é a denominação é genérica para uma família de termoplásticos amorfos formados pela combinação de monômeros acrilonitrila, butadieno e estireno. A proporção destes monômeros, bem como a estrutura molecular, pode ser manipulada para obter características diferentes para cada polímero formado por esta composição. A acrilonitrila contribui para resistência química e estabilidade térmica, o butadieno contribui para flexibilidade e resistência ao impacto e o estireno para rigidez, aparência superficial e processabilidade (Brady et al 2002).

O polímero resultante pode apresentar variações de suas características em função de sua utilização. Em geral, os diversos tipos de ABS apresentam alta estabilidade dimensional, boa aparência superficial, fácil processabilidade, bom isolamento elétrico, boa resistência química a ácidos e bases, não recomendado entretanto para contato com ésteres, cetonas e aldeídos. Contudo, apresenta pouca resistência à radiação ultravioleta, perdendo o brilho e coloração superficial e afetando suas propriedades mecânicas quando exposto a essa radiação (Brady et al 2002).

Nas dependências da empresa Busscar Ônibus S.A., localizada em Joinville/SC, foi acompanhando o processo de moldagem do ABS do tipo alta temperatura, denominado Vacum Forming, conforme procedimentos internos e confidenciais da empresa. O material utilizado na confecção de peças para ônibus, como por exemplo para-lamas, teto, protetor do tanque de combustível, revestimento interno de portas.

O processo de vacum forming, ou também chamado termoformagem por vácuo consiste no aquecimento de uma chapa termoplástica até sua temperatura de amolecimento seguida de conformação em um molde metálico pela ação do vácuo. Na FIG. 12 está ilustrado um molde onde este processo é feito utilizando placas de $2 \mathrm{~mm}$ de espessura. 


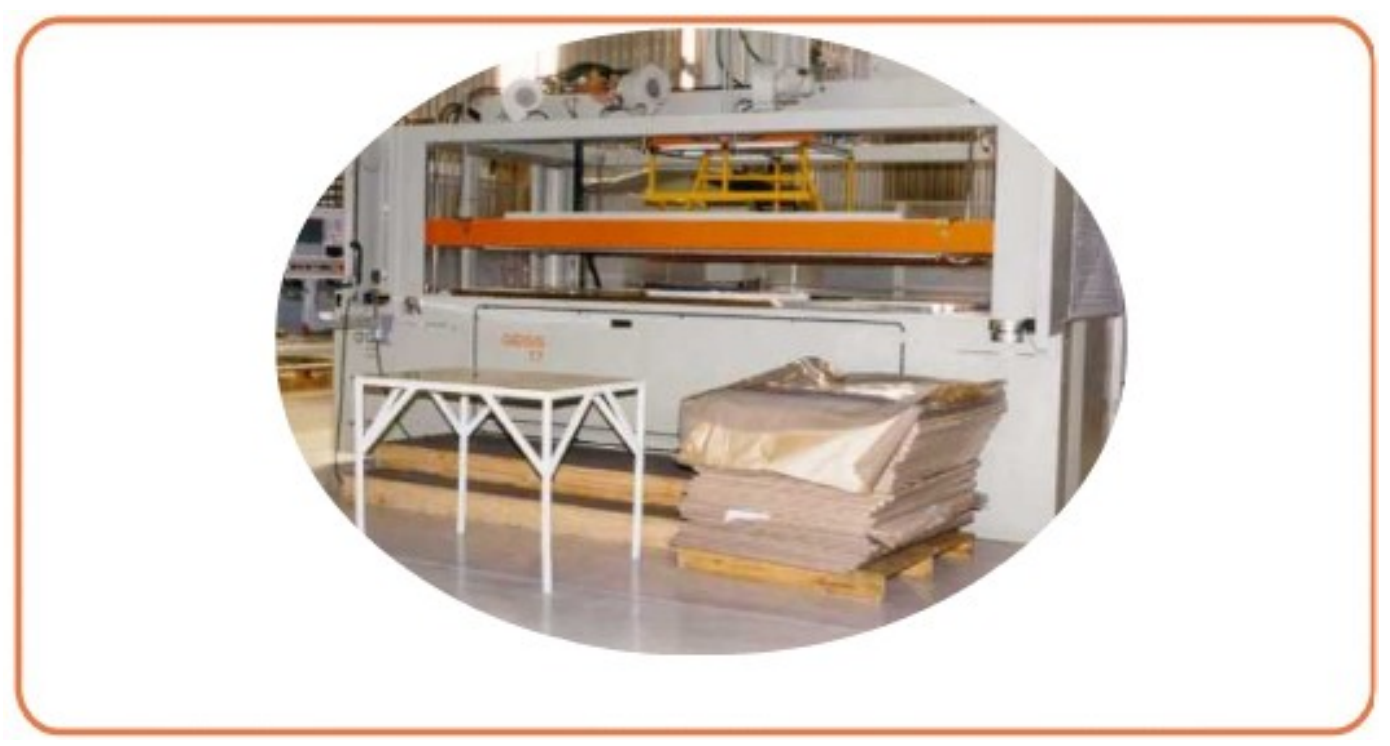

FIGURA 12 - Molde utilizado para conformação de peças em ABS por vacum forming (Tecnofibras, Produtos, 2008).

\subsubsection{Compósitos}

Para a fabricação dos corpos de prova foram utilizados laminados de poliéster reforçado com fibra de vidro moldados pelos processos de RTM e SMC, conforme processo descrito anteriormente. Segundo informação do fabricante, os compósitos apresentam uma fração volumétrica de $70 \%$ de matriz polimérica e $30 \%$ de fibras de vidro para ambos os processos.

Nas dependências da empresa Tecnofibras S.A., localizada em Joinville/SC, foram acompanhados os processos de moldagem pelos processos de RTM e SMC, onde foram coletadas placas de $2 \mathrm{~mm}$ de espessura para fabricação dos corpos de prova. A empresa utiliza os processos para fabricação de diversas peças para caminhões das linhas Volkswagen, Ford, Mercedes Benz, International, automóveis das linhas Mitsubishi e Tac, e ônibus da empresa Busscar.

Comumente os corpos de prova em compósitos de poliéster com fibra de vidro moldados por SMC e RTM são chamados pelos nomes dos processos, desta forma a partir de então chamaremos estes substratos pelos nomes dos processos. 


\section{Métodos}

\subsection{Preparação dos corpos de prova para o ensaio de resistência ao cisalhamento}

A avaliação da resistência ao cisalhamento foi feita utilizando-se um equipamento de ensaio universal Kratos. Para substratos de materiais compósitos poliméricos e termoplásticos foi utilizada a norma ASTM D3163 (2001), enquanto que para substratos metálicos, a norma ASTM D1002 (2005). Os procedimentos das duas normas são semelhantes quanto à preparação dos corpos de prova e ensaio, observando-se mínimas diferenças apenas textuais entre ambas.

Os corpos de prova metálicos, compósitos e termoplásticos foram fabricados a partir do corte de placas utilizando-se uma serra de corte circular de mesa, conforme mostrado na FIG. 13. Este equipamento utiliza um disco com grãos de óxido de alumínio, modelo SCI 302 do fabricante Silex Abrasivos, de dimensões 114,3x3,2x20 mm, com rotação de $3500 \mathrm{rpm}$. Utilizou-se este disco para todos os substratos, sem que apresentasse desgaste do corte. Um gabarito foi utilizado para manter a uniformidade lateral das peças.

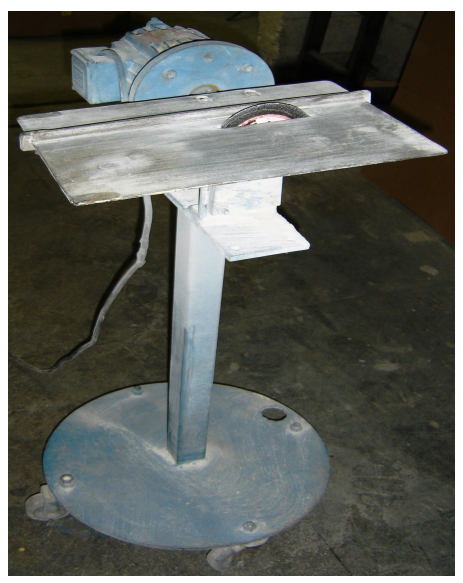

FIGURA 13 - Serra de corte circular de mesa.

Conforme os procedimentos definidos nas normas ASTM 3163 para os corpos de prova de compósitos e plásticos, as dimensões dos corpos de prova foram $25 \mathrm{~mm}$ de largura e 100 $\mathrm{mm}$ de comprimento. A área da colagem foi de $25 \times 25 \mathrm{~mm}$, conforme mostrado na FIG. 14. 
O presente trabalho teve como objetivo um estudo amplo do comportamento das juntas em compósito, metal e plástico, quando submetidas a diferentes condições de exposição. Foram 13 as condições de exposição, sendo necessária a fabricação de 10 corpos de prova para cada substrato, como se tem quatro substratos, foram preparados 520 corpos de prova.

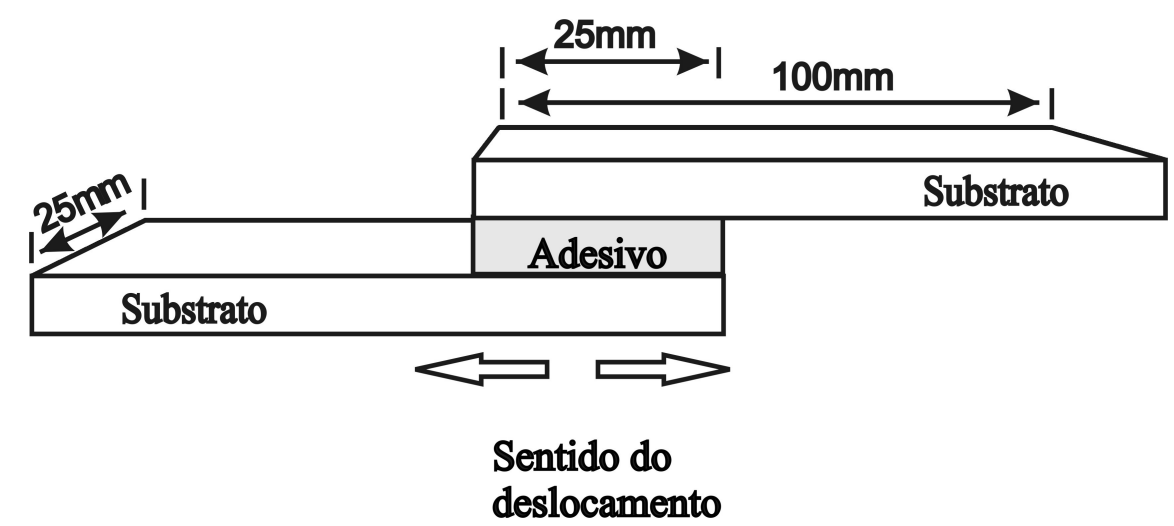

FIGURA 14 - Desenho do corpo de prova para ensaio de resistência ao cisalhamento conforme ASTM D 3163.

A preparação da superfície dos substratos compósitos poliméricos e do termoplástico foi feita por abrasão para remoção da camada superficial. Este procedimento é necessário para retirar os desmoldantes e que podem interferir na aderência do adesivo uretânico. O lixamento foi feito usando-se lixadeira de bancada, mostrada na FIG. 15 e lixa Norton R487, com grãos de carbeto de silício, granulometria P100. Outro procedimento complementar foi à limpeza com álcool isopropílico para remoção do pó produzido pelo lixamento.

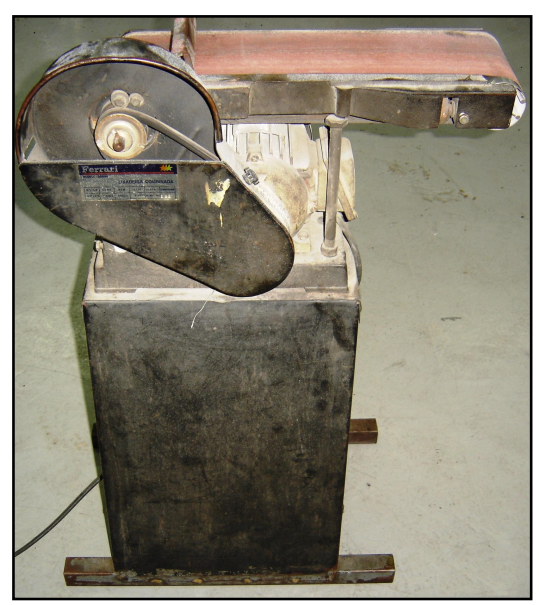

FIGURA 15 - Lixadeira de bancada 
Os corpos de prova em substratos metálicos tratados por zincagem e cromação preto foram apenas limpos com álcool isopropílico para remoção de sujeira ou oleosidade superficial.

O processo de colagem foi feito após as placas terem sido cortadas, lixadas e limpas com álcool isopropílico. Aplicou-se uma pequena quantidade do adesivo uretânico, cerca de $2 \mathrm{~g}$ por corpo de prova, previamente dosado e misturado com o equipamento descrito anteriormente, em uma das metades do corpo de prova e posicionado no centro da área lixada. Em seguida foi colocada cerca de 4 esferas de zircônia de 0,7 mm de diâmetro para delimitação da espessura da colagem. Esta delimitação faz-se necessária pois é sabido que a resistência mecânica de uma junta pode variar em função da espessura da camada de adesivo (Emrani et al., 2006). Após 24 horas, tempo necessário para a cura do adesivo uretânico a temperatura ambiente, os corpos de prova estão prontos para o ensaio.

$\mathrm{O}$ ensaio consistiu em prender o corpo de prova nas garras do equipamento e tracioná-los a uma velocidade constante de $12,7 \mathrm{~mm} \cdot \mathrm{min}^{-1}$ até a separação completa das duas placas, registrando-se a força máxima, a FIG. 16 mostra o arranjo para o ensaio. Para o cálculo da resistência ao cisalhamento utilizou-se a fórmula $\mathrm{R}=\mathrm{F} / \mathrm{A}$, onde $\mathrm{R}, \mathrm{F}$ e $\mathrm{A}$ expressam respectivamente resistência ao cisalhamento, força máxima na ruptura e área de colagem. $\mathrm{O}$ resultado pode ser expresso em kgf. $\mathrm{cm}^{-2}$ ou $\mathrm{MPa}$.

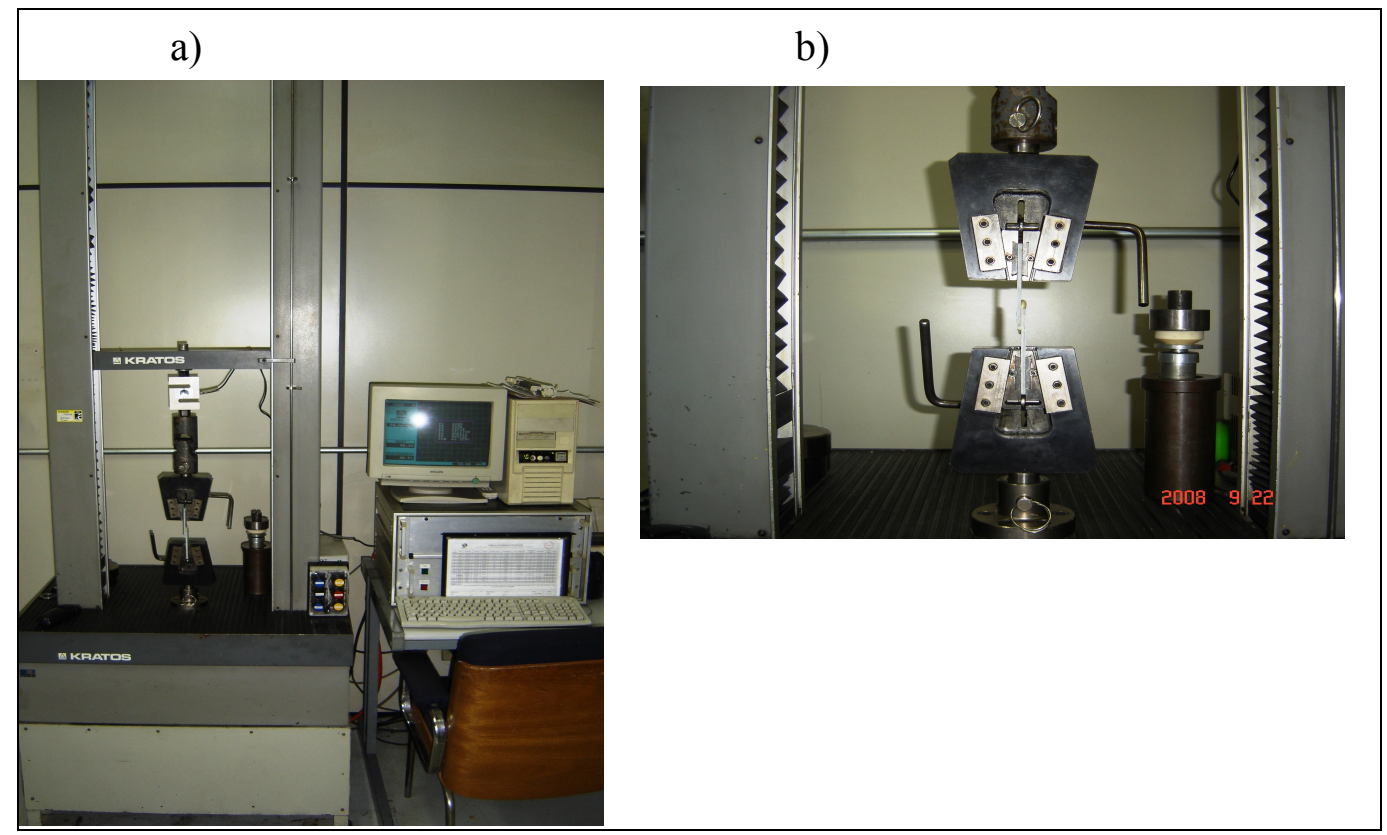

FIGURA 16 - a) Equipamento Kratos de ensaio universal, b) Corpo de prova posicionado para ensaio de resistência ao cisalhamento. 


\subsection{Acondicionamento dos corpos de prova}

Os corpos de prova preparados com o adesivo uretânico foram submetidos a diversos acondicionamentos, baseados nas normas WSBM11P27B da montadora Ford e TMS 6900 da montadora International.

Estes acondicionamentos visam à determinação da resistência de uma junta colada com adesivo sob condições de uso aceleradas em altas e baixas temperaturas e umidade relativa do ar. Para isto, utilizou-se estufa com circulação de ar, câmara fria, câmara úmida e exposição à névoa salina, conforme ilustrado na FIG. 17.

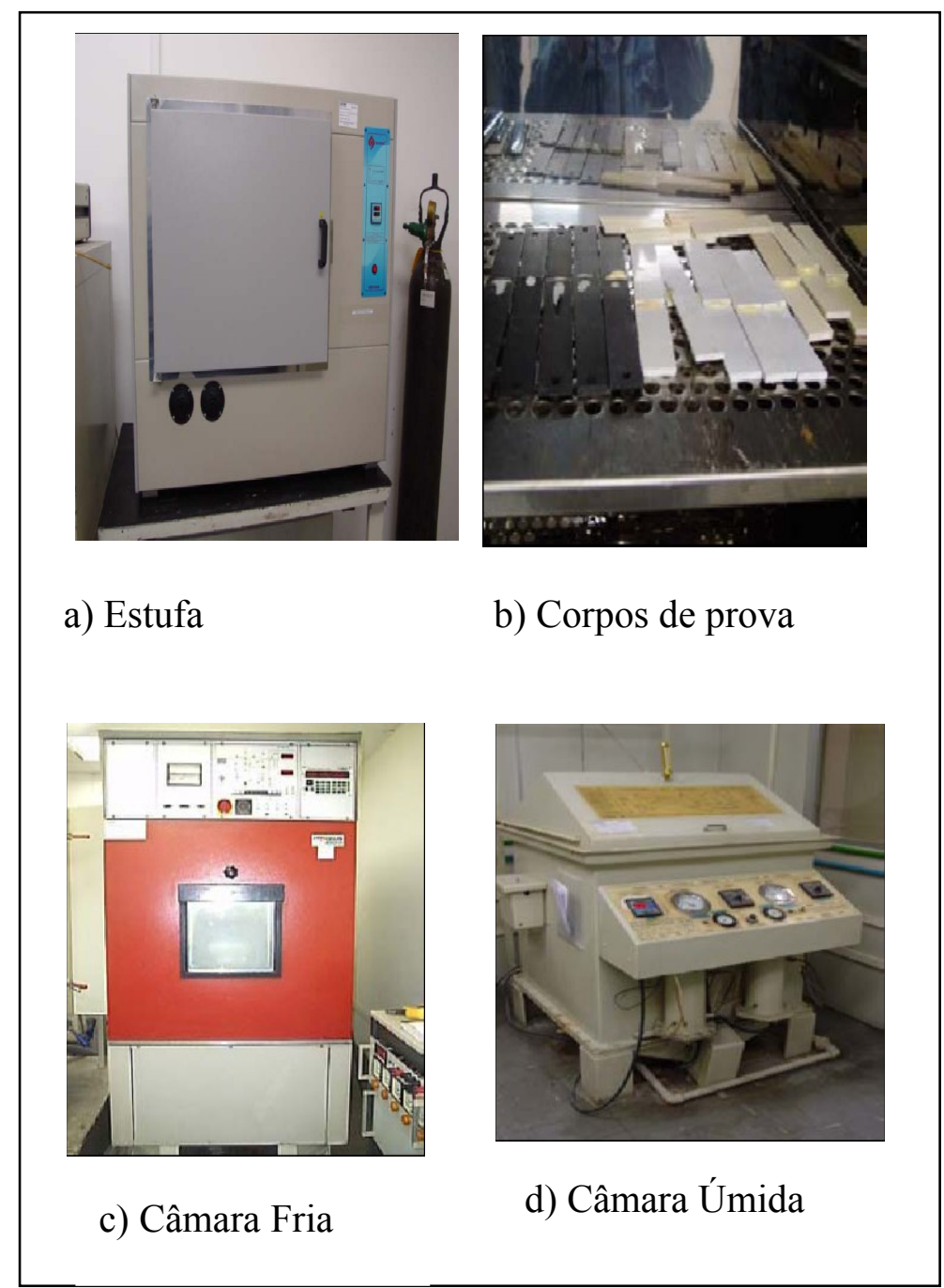

FIGURA 17 - a) Estufa de aquecimento, b) Corpos de prova na estufa, c) Câmara fria d) Câmara úmida. 
Para a exposição em névoa salina foi utilizada câmara modelo EQ.40 SS Super, conforme ilustração da FIG.18 Seguindo os procedimentos da norma ABNT NBR 8094, utilizou-se uma solução a $50 \mathrm{~g} / \mathrm{L}$ de $\mathrm{NaCl}$, controle de temperatura da câmara a $35^{\circ} \mathrm{C} \pm 2$ e do saturador a $47^{\circ} \mathrm{C} \pm 1$.

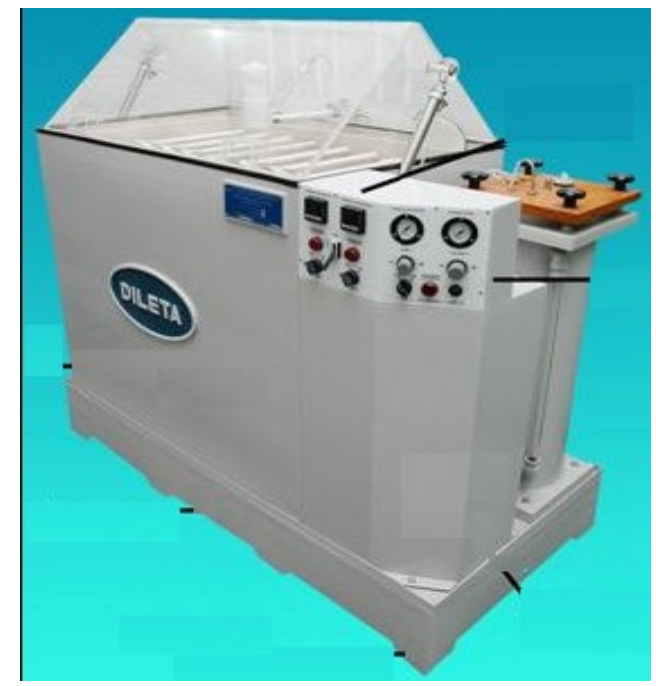

FIGURA 18 - Câmara de névoa salina. (Dileta, 2007)

\subsection{Preparação dos corpos de prova para ensaio de tração}

As propriedades mecânicas do adesivo uretânico, termoplástico (ABS), aço carbono zincado e cromado preto e os compósitos SMC e RTM, tais como resistência a tração, módulo de elasticidade e deformação longitudinal foram determinadas utilizando-se um equipamento de ensaio universal.

Para o adesivo, utilizaram-se procedimentos da norma ASTM D897 (2001). Os corpos de prova foram moldados pela adequada mistura e homogeneização do adesivo entre placas de vidro com espessura delimitada de $2 \mathrm{~mm}$. Após $48 \mathrm{~h}$ de cura do adesivo a temperatura ambiente, os corpos de prova foram cortados com auxílio do dispositivo mostrado na FIG.19. Os corpos de prova apresentam $200 \mathrm{~mm}$ de comprimento, largura nas extremidades de 25,4 mm e largura na região central de $10 \mathrm{~mm}$. 


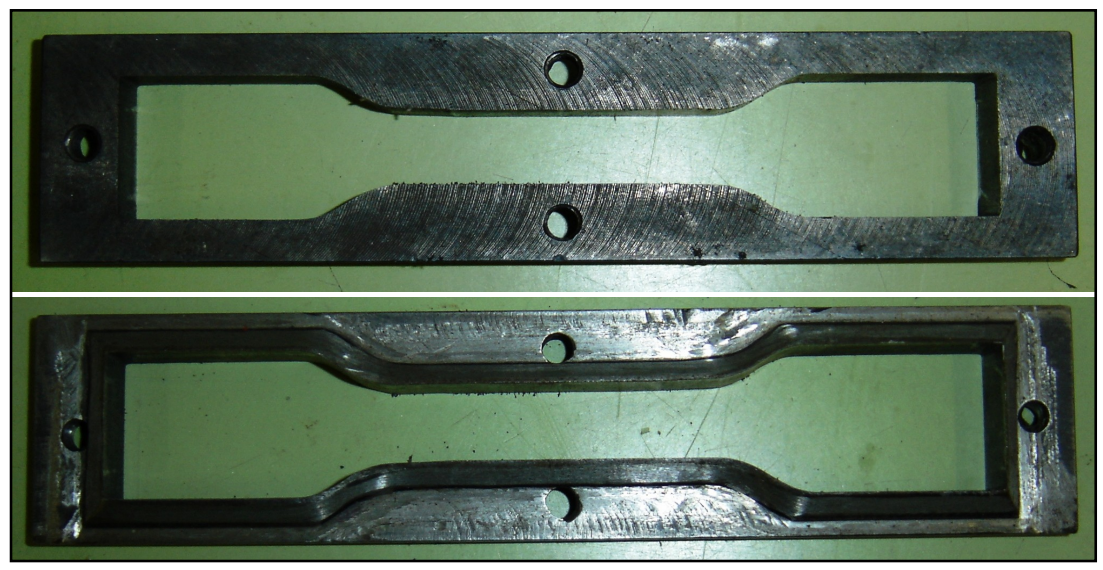

FIGURA 19 - Dispositivo para fabricação dos corpos de prova para ensaio de tração do adesivo.

Os corpos de prova dos compósitos SMC e RTM, bem como o termoplástico ABS foram preparados pelo corte de placas conforme procedimentos da norma ASTM D3039 (2007). A FIG. 20 apresenta o desenho do corpo de prova.

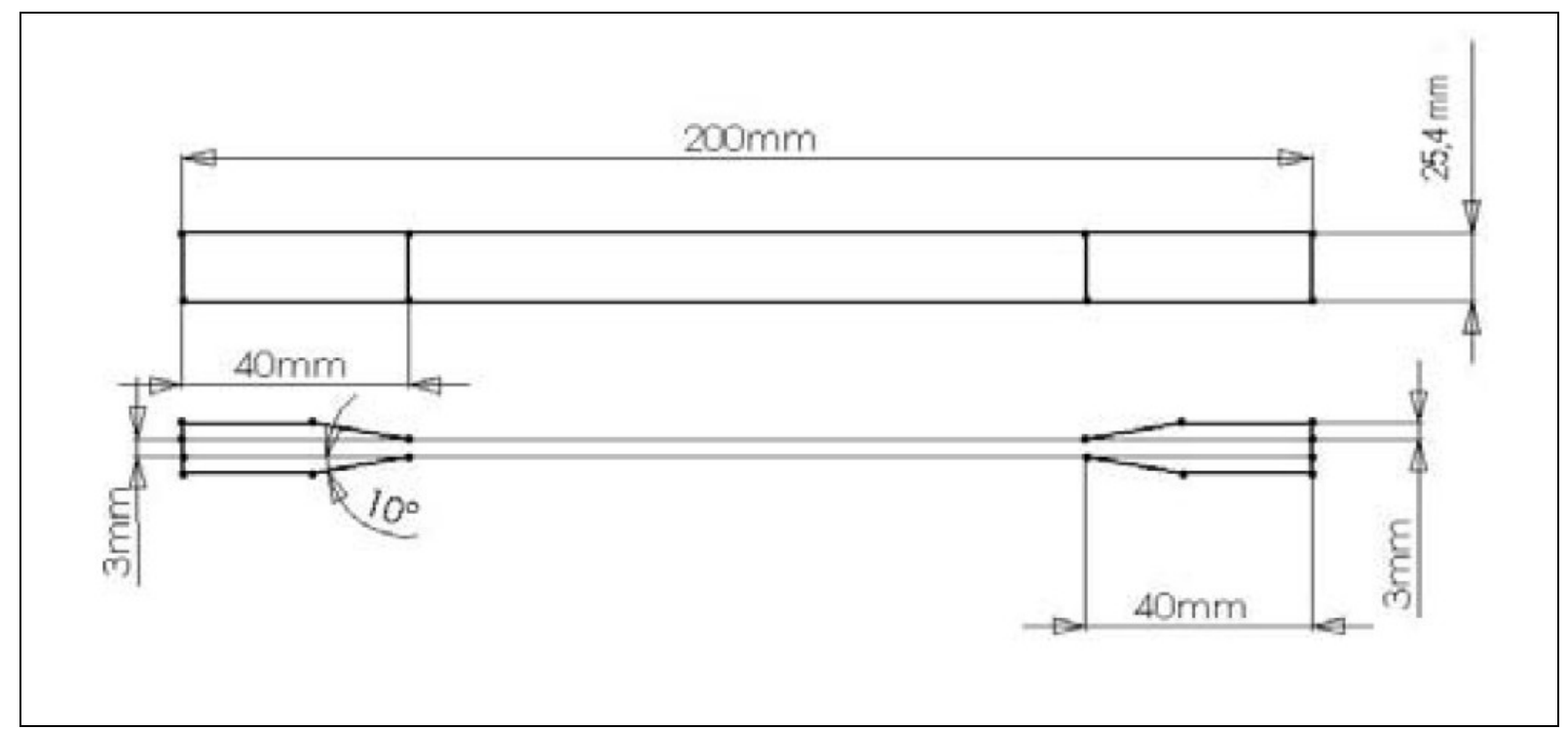

FIGURA 20 - Desenho do corpo de prova para ensaio de tração conforme norma ASTM D3039. 
Os corpos de prova apresentam $200 \mathrm{~mm}$ de comprimento e 25,4 $\mathrm{mm}$ de largura e $3 \mathrm{~mm}$ de espessura. Nas extremidades são coladas peças retangulares de apoio denominadas tabs, feitas do mesmo material com as dimensões $40 \mathrm{~mm}$ de comprimento, 25,4 $\mathrm{mm}$ de largura e 3 $\mathrm{mm}$ de espessura, colados simetricamente totalizando espessura de $9 \mathrm{~mm}$.

Para o aço carbono zincado e cromado preto, foi utilizada a norma ASTM E8M cujo corpo de prova está ilustrado na FIG. 21. Os corpos de prova apresentam $100 \mathrm{~mm}$ de comprimento, largura nas extremidades de $10 \mathrm{~mm}$ e largura na região central de $6 \mathrm{~mm}$.

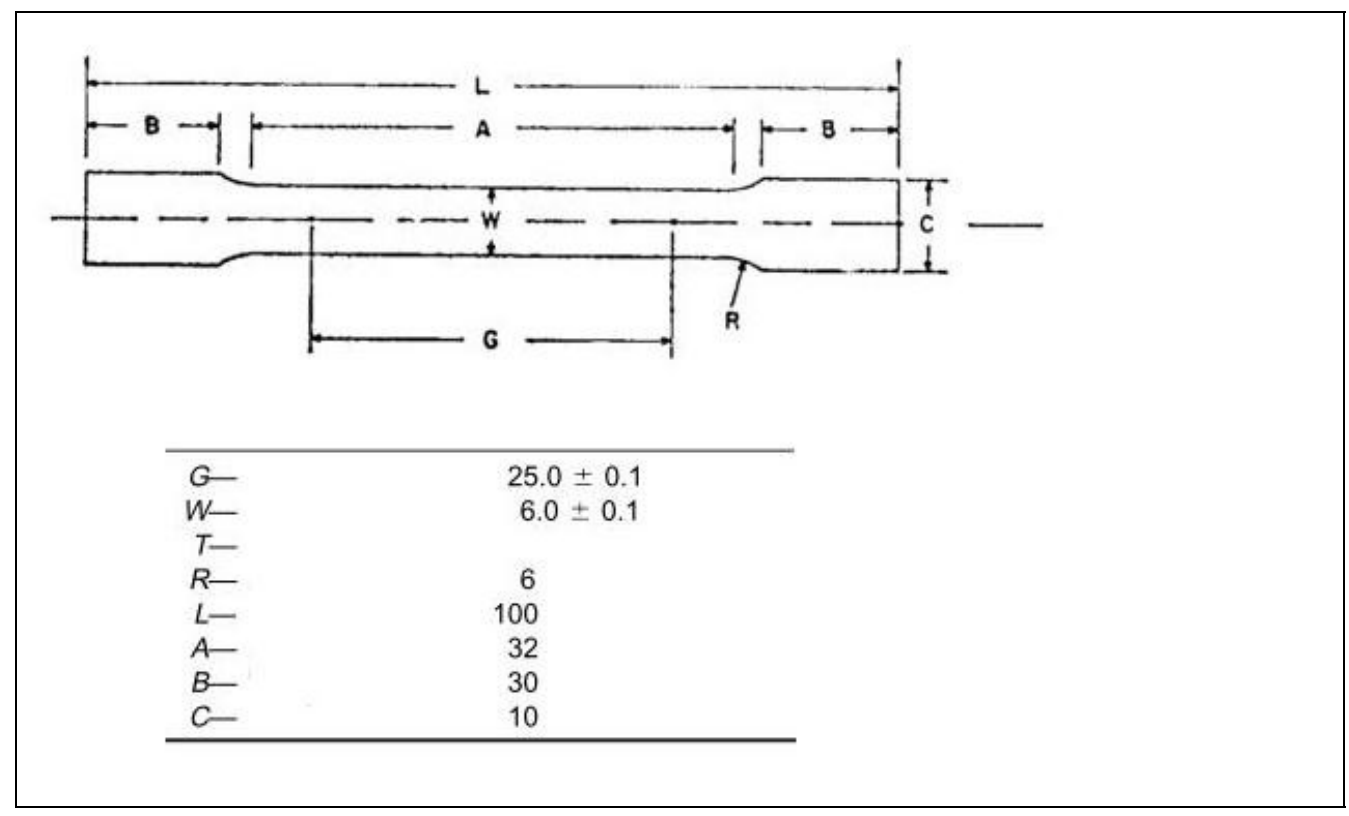

FIGURA 21 - Desenho do corpo de prova para ensaio de tração conforme norma ASTM E8M.

\subsection{Preparação dos corpos de prova para ensaio de resistência à clivagem}

A resistência a clivagem foi determinada utilizando-se um equipamento de ensaio universal de acordo com a norma ASTM D1062 (2002). Um dispositivo foi para a realização do ensaio. A FIG. 22 apresenta o detalhe deste dispositivo. Este dispositivo consiste de garras presas aos pinos que passam pelo corpo de prova, possibilitando assim exercer o esforço de clivagem. 

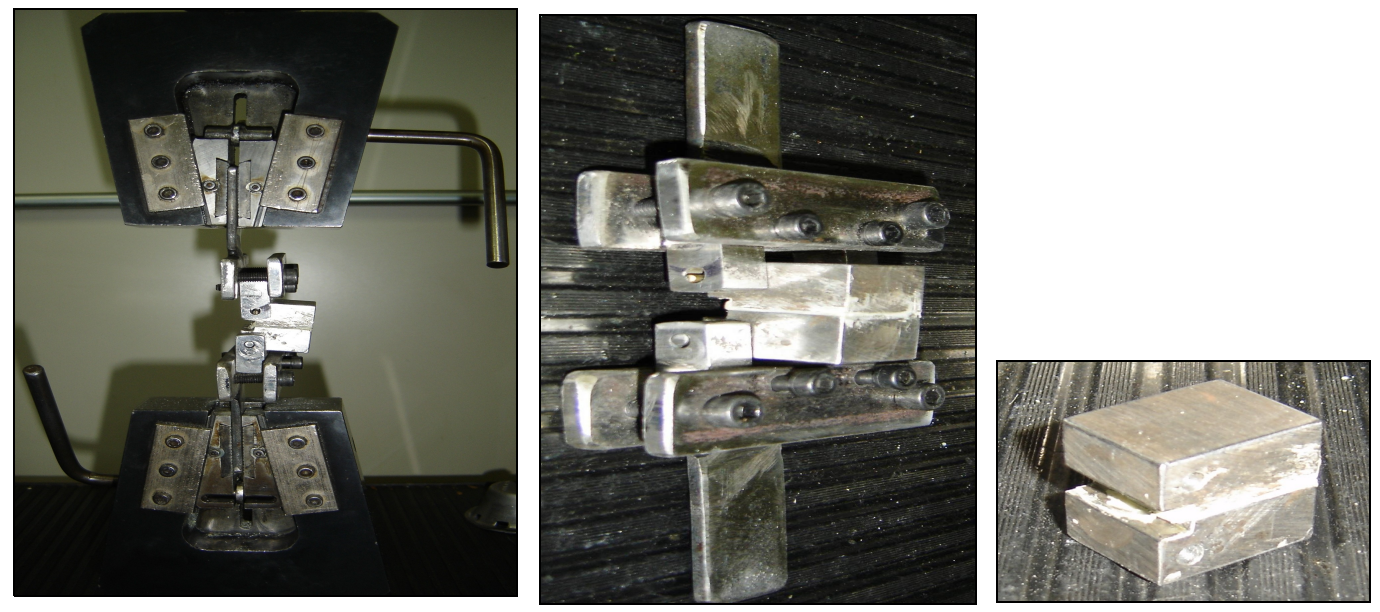

FIGURA 22 - Dispositivo adaptado para corpo de prova do ensaio de clivagem.

Os corpos de prova de material compósito, na forma de blocos, foram fabricados por laminação manual utilizando fibra de vidro e matriz de resina de poliéster. A geometria e dimensões, conforme FIG. 23, foram obtidas por usinagem em torno CNC. Também foram preparados corpos de prova em aço carbono utilizando a mesma técnica de usinagem empregada nos corpos de prova em compósito. Não foi possível preparar corpos de prova em ABS, pois os moldes disponíveis não permitiam obter placas com espessura mínima de 15,6 mm, necessárias para usinagem conforme geometria especificada.

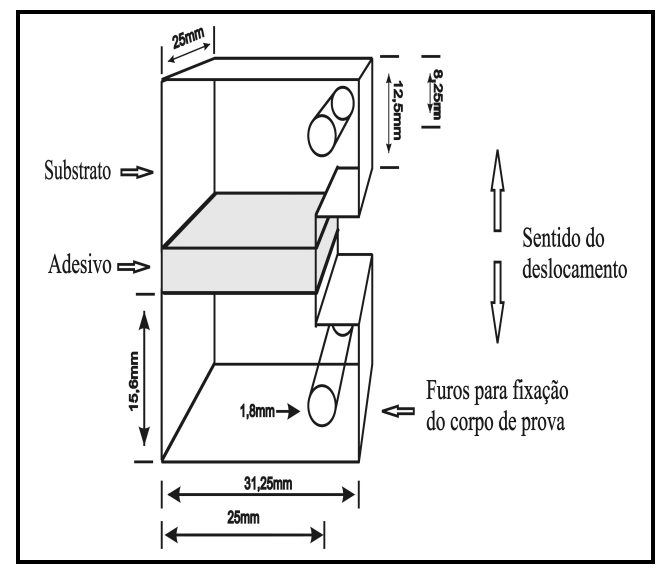

FIGURA 23 - Desenho do corpo de prova para ensaio de resistência à clivagem. 
A preparação da superfície de colagem foi a mesma usada para os ensaios de resistência ao cisalhamento. A superfície foi previamente lixada e limpa com álcool isopropílico, seguida de colagem de uma área de $6,45 \mathrm{~cm}^{2}$ com o adesivo uretânico, delimitando-se a espessura em 0,7 mm com esferas de zircônia.

Após 24 horas necessárias para a cura do adesivo uretânico à temperatura ambiente, os corpos de prova foram ensaiados a uma velocidade constante de $12,7 \mathrm{~mm} . \mathrm{min}^{-1}$ até a separação completa dos dois blocos. Para o cálculo da resistência à clivagem, utilizou-se a fórmula $\mathrm{RCl}=\mathrm{F} / \mathrm{L}$, onde $\mathrm{RCl}, \mathrm{F}$ e $\mathrm{L}$ expressam respectivamente resistência a clivagem, força máxima na ruptura e largura do corpo de prova. $\mathrm{O}$ resultado pode ser expresso em $\mathrm{N} / \mathrm{mm}$.

Destaca-se que neste ensaio a força máxima é dividida pela largura do corpo de prova $(25 \mathrm{~mm})$, pois o comprimento não interfere na resistência à clivagem.

\subsection{Métodos de preparação de superfície.}

Considerando que a área de atuação dos adesivos está concentrada na superfície do substrato é necessário um cuidado especial na preparação da superfície antes do contato com o adesivo. Diversos métodos estão descritos na literatura, como por exemplo, abrasão, limpeza com solventes, flambagem, tratamento com plasma, tratamentos químicos. Dentre eles os mais comuns utilizados industrialmente são abrasão por lixamento e limpeza com solventes.

Nos compósitos em geral e particularmente no compósito poliéster/fibra de vidro do presente estudo, a superfície da peça fabricada apresenta uma fina camada do agente desmoldante que foi aplicada no molde e que poderá comprometer o desempenho da aderência de qualquer adesivo. O lixamento é o método mais empregado nestes casos devido à sua simplicidade de execução e baixo custo, porém apresenta a desvantagem de gerar uma nuvem de poeira, podendo comprometer a saúde do trabalhador. Esta poeira acaba sendo acumulada nas instalações industriais prejudicando não só a ergonomia dos trabalhadores como também danificando a operação de equipamentos. Na tentativa de buscar opões ao método de lixamento, este trabalho investigou uma forma alternativa de tratamento de superfície, que consiste no tratamento com plasma e limpeza por solvente. 


\subsubsection{Exposição ao plasma}

O plasma é o quarto estado da matéria, ou como alguns preferem um gás ionizado, criado a partir de uma alta descarga de energia sobre um gás. Neste estado ocorre a emissão de luz e formação de íons livres e elétrons que podem ser usados para como tratamento de superfícies de difícil adesão (Plasmatreat, 2011).

Um sistema de tratamento de superfície com exposição ao plasma emprega ar comprimido e energia para gerar um jato de plasma aplicado sobre qualquer superfície para aplicações de colagem. Mais detalhes a respeito do equipamento utilizado poderão ser obtidos no anexo D. Na FIG.24 são mostrados o gerador e o jato de plasma utilizados para os testes. O jato de plasma tem sido empregado promovendo uma limpeza superficial e também modificando quimicamente a superfície.

A limpeza superficial que ocorre pela ação do plasma é devida a volatilização e arraste de constituintes orgânicos presentes na superfície, geralmente desmoldantes, já a modificação química ocorre devido a interação dos íons e elétrons do plasma com a superfície do material que se pretende colar (Chan et al., 1996).

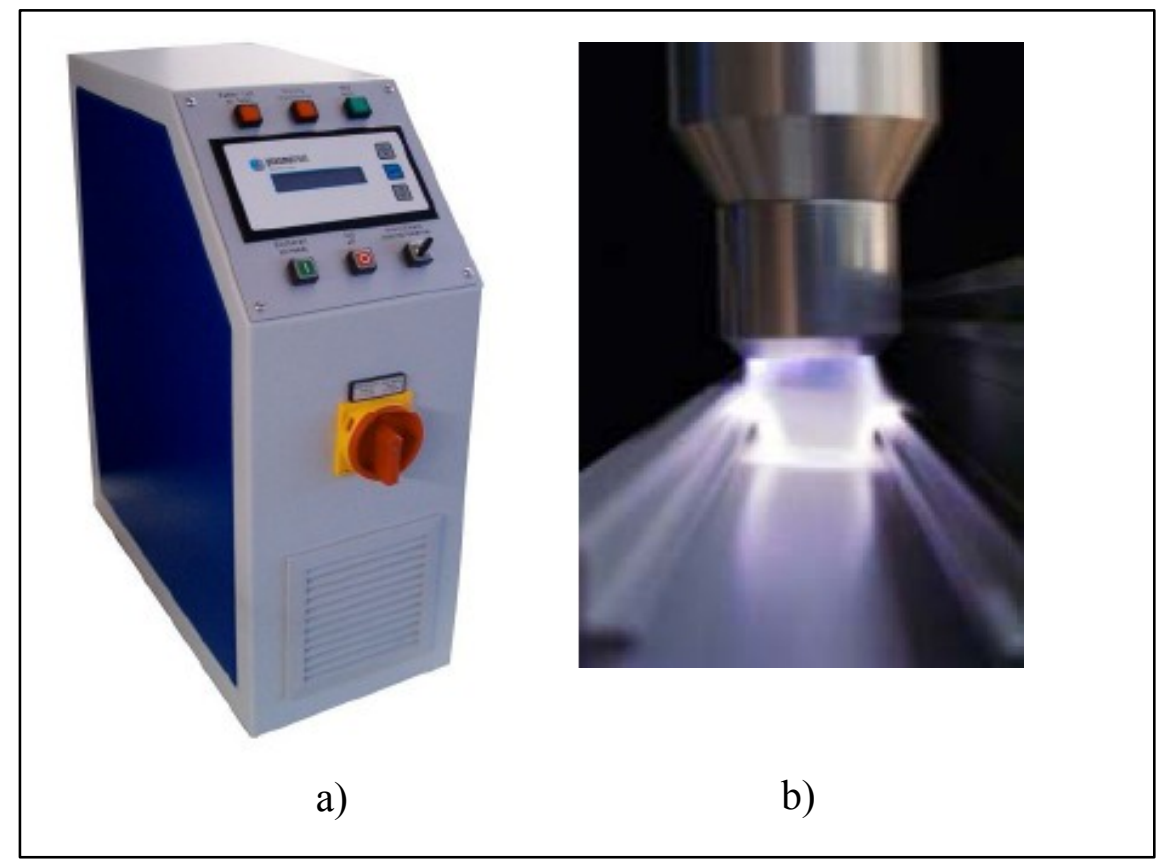

FIGURA 24 - a) gerador de plasma de ar comprimido, b) jato de plasma (Plasmatreat, 2011).

No presente estudo utilizou-se plasma de ar comprimido exposto pelo tempo de $2 \mathrm{~s}$ sobre as superfícies das peças a serem coladas. Um modo de acompanhar a eficiência do 
tratamento é a medição da energia de superfície por emprego do Test Inks também descrito no anexo D.

O Test Ink é composto por um kit contendo várias soluções padrão com indicação energia de superfície desde $20 \mathrm{mN} . \mathrm{m}^{-1}$ até $90 \mathrm{mN} . \mathrm{m}^{-1}$ com intervalos de $2 \mathrm{mN} . \mathrm{m}^{-1}$. Ao aplicar uma pequena gota de um dos padrões sobre o substrato, se a gota for capaz de molhar a superfície significa que a energia de superfície daquele substrato é igual ou maior do que a do padrão, parte-se então para testar soluções de maior energia de superfície até que se encontre uma solução que não seja capaz de molhá-lo, quando isto ocorre encontra-se qual o intervalo de energia de superfície aquele substrato se encontra.

Substratos plásticos de difícil colagem apresentam energias entre $20-40 \mathrm{mN} . \mathrm{m}^{-1}$ e após serem tratados alcançam valores entre 70 a $80 \mathrm{mN}^{-1} \mathrm{~m}^{-1}$, conforme descritos no procedimento do Test Ink no anexo D.

\subsubsection{Limpeza com solventes}

Outro método de tratamento de superfície utilizado após o lixamento é a limpeza com solvente para remoção do excesso de pó gerado pela abrasão. No entanto o objetivo deste estudo é selecionar um solvente que seja capaz de em apenas uma etapa preparar a superfície para o contato com o adesivo evitando assim a formação de poeira. Foram utilizados os solventes Tricloroetileno, Tolueno, Acetona, Isopropanol, Pentano e Starquímica LD1264 aplicados sobre os substratos por uso de flanela limpa de algodão e friccionados por cinco vezes.

\subsection{Análise Térmica}

O conjunto de técnicas analíticas por meio das quais uma propriedade física de uma substância ou de seus produtos de reação é medida em função da temperatura, enquanto essa substância é submetida a uma programação controlada de temperatura e sob uma atmosfera controlada é conhecida como análise térmica (WENDLANDT, 1974, p.1-6). Dentre as diversas técnicas disponíveis, foram utilizadas neste estudo a análise Termogravimétrica (TG), Análise térmica diferencial (DTA), Calorimetria diferencial exploratória (DSC) e Análise termomecânica (TMA), esta última também chamada de Dilatometria. 


\subsubsection{Termogravimetria (TG)}

A termogravimetria é uma técnica na qual a mudança de massa de uma amostra é registrada em função da temperatura. Existem três modos de termogravimetria: a estática onde a variação de massa de uma amostra é registrada em uma temperatura constante é registrada, a semi-estática onde a amostra é aquecida até se observar massa constante, ou seja, não ocorre mais perda de massa, e então submetida a uma série de incrementos de temperatura e por último a termogravimetria dinâmica onde a amostra é aquecida de forma pré-determinada, preferencialmente linear e a variação da massa é registrada, sendo esta a mais usual (Wendlandt, 1974, p.6-61).

A curva obtida da variação de massa em função da temperatura revela informações sobre a estabilidade térmica, composição inicial da amostra, composição de compostos intermediários que podem ser formados e composição do resíduo.

A maioria das aplicações da termogravimetria tem sido a caracterização de polímeros, como por exemplo, comparações de estabilidade térmica, efeito de aditivos na estabilidade térmica, presença de umidade e aditivos, estudos de cinética de degradação, avaliação quantitativa da composição de copolímeros no sistema e estabilidade a oxidação.

No estudo dos adesivos poliméricos por meio da termogravimetria pode-se comparar a estabilidade térmica entre o adesivo e o substrato. Isto permite determinar qual material apresentará menor resistência à degradação térmica e consequentemente qual a temperatura máxima de exposição que a junta resistirá. Também é possível quantificar o teor de matéria inorgânica no adesivo, oriunda das cargas minerais utilizadas na formulação.

\subsubsection{Calorimetria diferencial exploratória (DSC)}

Esta técnica consiste em manter a amostra e uma referência termicamente inerte em isotermia, pela aplicação de energia elétrica para compensar os eventos endotérmicos e exotérmicos que possam ocorrer durante uma programação linear de aquecimento ou resfriamento. A curva obtida neste ensaio apresenta as variações de energia absorvidas e liberadas durante o aquecimento ou resfriamento na forma de picos e vales onde, ao contrário do observado no DTA, os eventos exotérmicos são representados por vales e os eventos endotérmicos são representados por picos (Wendlandt, 1974, p. 134-194). No entanto, 
dependendo do software do fabricante do equipamento estas indicações podem ser ao contrário.

Para determinação do calor liberado durante a reação química dos componentes A e B do adesivo uretânico, respectivamente poliol e isocianato, utiliza-se uma amostra de adesivo recém preparado, ou seja, logo após a mistura dos dois componentes a amostra é colocada no recipiente apropriado e levada para o ensaio.

Em outro ensaio para uma amostra do adesivo uretânico já curado poderão ser observados eventos como transição vítrea, a cura do polímero uretânico e temperatura de degradação térmica.

\subsection{Espectroscopia Vibracional na região do infravermelho por reflectância atenuada (ATR)}

Esta técnica permite a identificação e caracterização química de amostras em pó, pastas e adesivos que não poderiam ser analisados de forma usual como em filmes ou pastilhas de $\mathrm{KBr}$, devido sua natureza opaca. O método baseia-se no efeito sofrido por um feixe de radiação infravermelho, na faixa aproximada de 10.000 a $100 \mathrm{~cm}^{-1}$, quando ele passa de um meio mais denso (cristal ATR) para um meio menos denso (amostra) e ocorre a reflexão. Uma parte da radiação é refletida totalmente e outra penetra uma pequena distância dentro da amostra, esta penetração é chamada de onda evanescente e depende de vários parâmetros como ângulo de incidência do sinal, comprimento de onda, índice de refração do material e do próprio cristal. A interação da onda evanescente resulta na absorção da radiação pela amostra e corresponde ao espectro de transmissão dessa mesma amostra.

Este processo de absorção é quantificado quando se obtém um espectro vibracional caracterizado por uma série de bandas de vibração-rotação. As vibrações moleculares podem ser classificadas como deformação axial ou angular. As deformações axiais, ou estiramentos, são oscilações radiais das distâncias entre os núcleos e as angulares envolvem mudanças de ângulos entre as ligações. (Silverstein et al, 1975, p. 298) Os grupos funcionais de compostos orgânicos absorvem em frequências características no infravermelho, de modo que em um gráfico de intensidade da radiação pela frequência é possível identificar os grupos funcionais de um padrão ou de uma material que se deseja analisar. 
No presente trabalho utilizou-se um espectrômetro Nicolet Nexus 470, contendo um cristal de $\mathrm{ZnSe}$ de cerca de $7 \mathrm{~cm}$ de comprimento onde o feixe de infravermelho incide em uma das pontas, percorre toda a extensão do cristal, entra em contato com a amostra e vai para o detector. As amostras dos substratos foram analisadas antes e após contato com o adesivo para avaliar a interação adesivo - substrato. 


\section{Resultados e Discussão}

Iniciou-se a caracterização mecânica do sistema adesivo e substratos avaliando-se primeiramente as propriedades mecânicas individuais de cada um deles.

Posteriormente investigou-se o comportamento da aderência do adesivo uretânico sobre os substratos ABS, SMC, RTM e ACZCP (aço carbono zincado e cromado preto), por meio do uso da avaliação da resistência ao cisalhamento de corpos de prova logo após a colagem e após passarem por condições de temperatura alta e baixa, além de agentes críticos como água e névoa salina. Ainda dentro da avaliação da aderência avaliou-se a resistência a clivagem, pois em muitas situações de uso prático este tipo de esforço pode ocorrer.

Sabendo-se que em uma determinada junta as propriedades térmicas são diferentes entre o adesivo e os substratos, avaliou-se por uso de diversas técnicas o comportamento térmico do adesivo e dos substratos.

A análise estatística da incerteza dos resultados foi feita pelo cálculo do erro das medidas conforme distribuição t de Student, considerando 4 graus de liberdade e nível de confiança de $90 \%$, e $\mathrm{t}=2,1318$. A fórmula abaixo representa o erro das medidas:

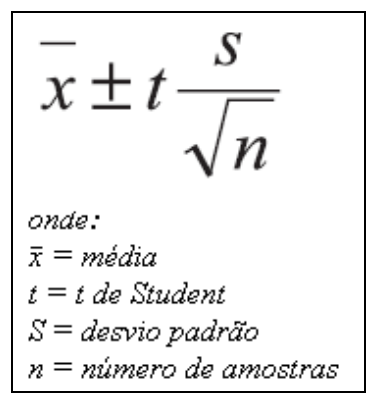

A incerteza expandida foi calculada por meio da soma dos erros das medições com o erro do equipamento, este último foi coletado na calibração anterior aos ensaios, este erro foi de $0,01 \mathrm{MPa}$.

\subsection{Caracterização mecânica do adesivo}

Os resultados de tensão de ruptura, módulo de elasticidade e deformação longitudinal do adesivo Masterpur Estrutural 300 encontram-se na TAB. 2. 
TABELA 2 - Tensão de ruptura, módulo de elasticidade e deformação longitudinal do adesivo Masterpur Estrutural 300

\begin{tabular}{lcc}
\hline \multicolumn{1}{c}{ Propriedade } & Resultado & $\begin{array}{c}\text { Incerteza } \\
\text { expandida }\end{array}$ \\
\hline Tensão de ruptura (MPa) & 6,8 & 0,3 \\
Módulo de elasticidade (MPa) & 92,3 & 1,1 \\
Deformação longitudinal (\%) & 61,5 & 0,5 \\
\hline
\end{tabular}

Os resultados mostraram que o adesivo apresenta boa tensão de ruptura, com uma elevada deformação longitudinal quando comparado com alguns polímeros termofixos, como por exemplo matrizes poliméricas de poliéster insaturado e epóxi, que apresentam tensão de ruptura de aproximadamente $10 \mathrm{MPa}$ e deformações que variam de 1 a $3 \%$.

A deformação que o material apresentou é de importância para aumentar a durabilidade da junta, pois neste caso o adesivo poderá absorver elasticamente os esforços aos quais ela será submetida, evitando uma fratura prematura da junta.

\subsection{Caracterização mecânica dos substratos}

Os resultados de tensão de ruptura, módulo de elasticidade e deformação longitudinal dos compósitos de poliéster reforçado com fibra de vidro fabricados por SMC e RTM, do termoplástico ABS e do ACZCP encontram-se na TAB. 3.

TABELA 3 - Propriedades mecânicas dos substratos.

\begin{tabular}{ccccccc}
\hline Substrato & $\begin{array}{c}\text { Tensão de } \\
\text { Ruptura (MPa) }\end{array}$ & $\begin{array}{c}\text { Incerteza } \\
\text { expandida }\end{array}$ & $\begin{array}{c}\text { Módulo de } \\
\text { Elasticidade (GPa) }\end{array}$ & $\begin{array}{c}\text { Incerteza } \\
\text { expandida }\end{array}$ & $\begin{array}{c}\text { Deformação } \\
\text { longitudinal (\%) }\end{array}$ & $\begin{array}{c}\text { Incerteza } \\
\text { expandida }\end{array}$ \\
\hline Masterpur & 6,8 & 0,3 & 0,09 & 0,001 & 61,5 & 0,5 \\
Estrutural 300 & & & & & & 0,7 \\
SMC & 37,1 & 0,6 & 7,1 & 0,5 & 0,8 & 0,1 \\
RTM & 55,4 & 0,6 & 10,2 & 0,5 & 16,8 & 0,2 \\
ABS & 24,2 & 0,5 & 2,0 & 0,1 & 51,0 & 0,3 \\
ACZCP & 322,0 & 2,5 & 210 & 1,2 & & \\
\hline
\end{tabular}

Os resultados da caracterização mecânica dos substratos utilizados neste estudo mostra que para os dois compósitos, de SMC e RTM, a tensão de ruptura encontra-se entre 37,1 e 
55,4 MPa e a deformação longitudinal inferior a 1\%. Como estes compósitos foram moldados com fibras multidirecionais, não se faz necessária a avaliação destas propriedades no sentido longitudinal e transversal. Apenas em uma das direções já é suficiente para caracterizar o material, pois se considera o material como quasi-isotrópico.

Comparando as propriedades dos compósitos com o adesivo Masterpur Estrutural 300, os compósitos apresentam tensão de ruptura bem superior ao apresentado pelo adesivo, enquanto que a deformação longitudinal foi muito inferior.

O termoplástico ABS apresentou uma tensão de ruptura inferior aos compósitos, porém ainda muito superior ao adesivo Masterpur Estrutural 300. A deformação longitudinal é característica de termoplástico, sempre mais elevada que a dos compósitos.

Embora as tensões de ruptura dos substratos foram superiores a do adesivo. A adesão mostrou-se eficiente nestas uniões, pois as falhas nos corpos de prova colados com o adesivo uretânico foram nos substratos

O ACZCP apresenta tensão de ruptura muito mais elevada do que o adesivo uretânico e os substratos compósitos, de forma que nas juntas formadas com este substrato poderá ser observado o comportamento do adesivo sem interferência de falhas dos substratos.

\subsection{Resistência ao cisalhamento de juntas coladas à temperatura ambiente}

Os corpos de prova de ABS, de compósitos moldados por SMC e RTM e ACZCP, unidos por meio do adesivo uretânico foram ensaiados para avaliação da resistência ao cisalhamento a $25^{\circ} \mathrm{C}$, conforme norma ASTM D3163 (2001) para substratos poliméricos compósitos e termoplásticos e a norma ASTM D1002 (2005) para substratos metálicos. Os procedimentos descritos nestas duas normas são os mesmos que se referem às dimensões do corpo de prova e velocidade do deslocamento. Os resultados encontram-se na TAB. 4.

Nas juntas formadas pelos substratos compósitos houve falha do substrato. No SMC ocorreu delaminação e no RTM houve ruptura do corpo de prova. Isto mostra que a união com $\mathrm{o}$ adesivo foi eficiente, pois o substrato falhou antes do adesivo sofrer ruptura, seja por delaminação ou ruptura do corpo de prova. É de se compreender que a eficiência da adesão deve estar intimamente ligada à interação entre o adesivo e a superfície do substrato, de modo que este fenômeno sugere um estudo da interação entre eles. 
TABELA 4 - Avaliação da resistência ao cisalhamento das juntas a $25^{\circ} \mathrm{C}$.

\begin{tabular}{cccc}
\hline Substrato & $\begin{array}{c}\text { Resistência ao } \\
\text { cisalhamento (MPa) }\end{array}$ & $\begin{array}{c}\text { Incerteza } \\
\text { expandida }\end{array}$ & Forma de ruptura \\
\hline SMC & 5,8 & 0,40 & Delaminação \\
RTM & 6,1 & 0,38 & Corpo de prova \\
ABS & 3,6 & 0,21 & Corpo de prova \\
ACZCP & 10,7 & 0,73 & Coesiva \\
\hline
\end{tabular}

Nos corpos de prova de ABS também ocorreu falha do substrato por ruptura do corpo de prova, apresentando um valor de resistência ao cisalhamento muito inferior aos obtidos para os de SMC e RTM. Isto se deve ao fato de o corpo de prova de ABS apresentar tensão de ruptura também inferior, portanto a ruptura ocorreu mais facilmente neste substrato.

A resistência observada nos corpos de prova do aço carbono foi muito superior as apresentadas nos substratos poliméricos, uma vez que a falha se deu coesivamente, ou seja, no interior do corpo do adesivo. Vê-se por isto que não se podem comparar resultados de resistência ao cisalhamento sem levar em consideração o modo de falha.

Em todos os corpos de prova de SMC, RTM, ABS e ACZCP, os valores encontrados devem ser entendidos como sendo inferiores à resistência adesiva ao cisalhamento, uma vez que houve ruptura do substrato e falha coesiva antes que ocorresse a falha adesiva. Assim, seria pertinente uma comparação entre eles quanto à capacidade do adesivo em interagir com a superfície do compósito.

A excelente aderência mostrada pelo adesivo uretânico deve-se não só a qualidade do adesivo, mas também devido a eficiente interação entre o adesivo e o substrato. No caso dos materiais compósitos de SMC e RTM, considerando que a matriz polimérica está em maior porcentagem, a interação preferencial será com ela. Esta interação pode ser explicada pela alta polaridade da matriz polimérica de poliéster devido à presença principalmente de radicais hidroxilas na cadeia polimérica (Sanchez et al, 2005).

As hidroxilas da matriz polimérica podem interagir com o adesivo poliuretânico tanto eletrostaticamente como por reação química com os grupos isocianatos presentes no adesivo. Esta possível reação pode ser entendida se observarmos a reação química do adesivo poliuretânico, conforme ilustrado na FIG. 25, que é formado pela reação de um poliol e um isocianato, este último contendo um pequeno excesso utilizado para reticulação. Deste modo, durante a aplicação do adesivo o excesso de isocianatos pode reagir, entre outros grupos, com 
grupos hidroxilas da superfície do substrato e melhorar a aderência, aumentando assim a força adesiva ente adesivo e substrato.

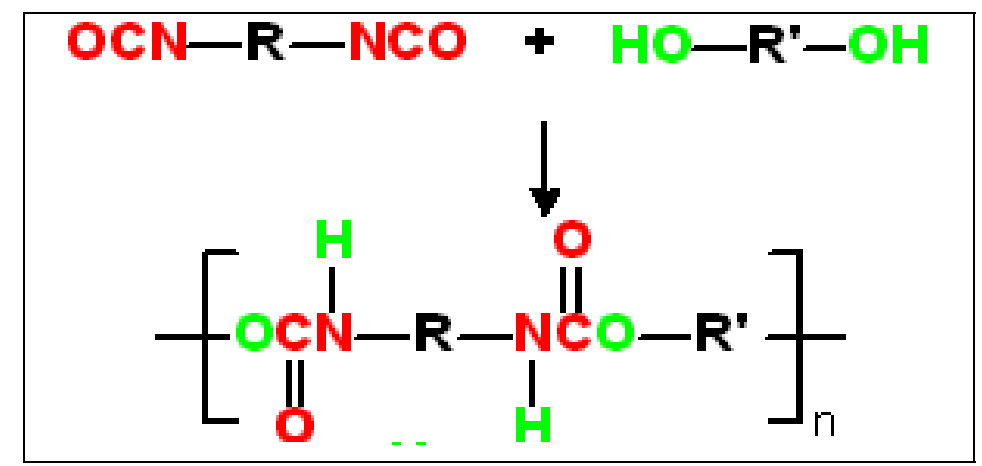

FIGURA 25 - Reação do poliol com isocianato (Wikipédia, 2011).

Para analisar os resultados obtidos nos ensaios de resistência ao cisalhamento quanto ao modo de ruptura, é útil saber que uma junta colada submetida ao esforço de cisalhamento pode, conforme ilustrado pela FIG. 26, sofrer falha de quatro modos diferentes: 1-falha do substrato, 2-falha na interface do adesivo e substrato, também chamada falha adesiva, 3-falha no interior do corpo de adesivo, também chamada de falha coesiva e 4-falha do substrato fora do plano, mais conhecida como delaminação, que ocorre apenas para materiais anisotrópicos por falha interlaminar.

Deve-se ressaltar que não somente os valores de resistência ao cisalhamento devem ser considerados, mas também o modo de falha, haja vista que nos substratos de materiais compósitos ela pode ocorrer tanto por delaminação como por ruptura do corpo de prova. 


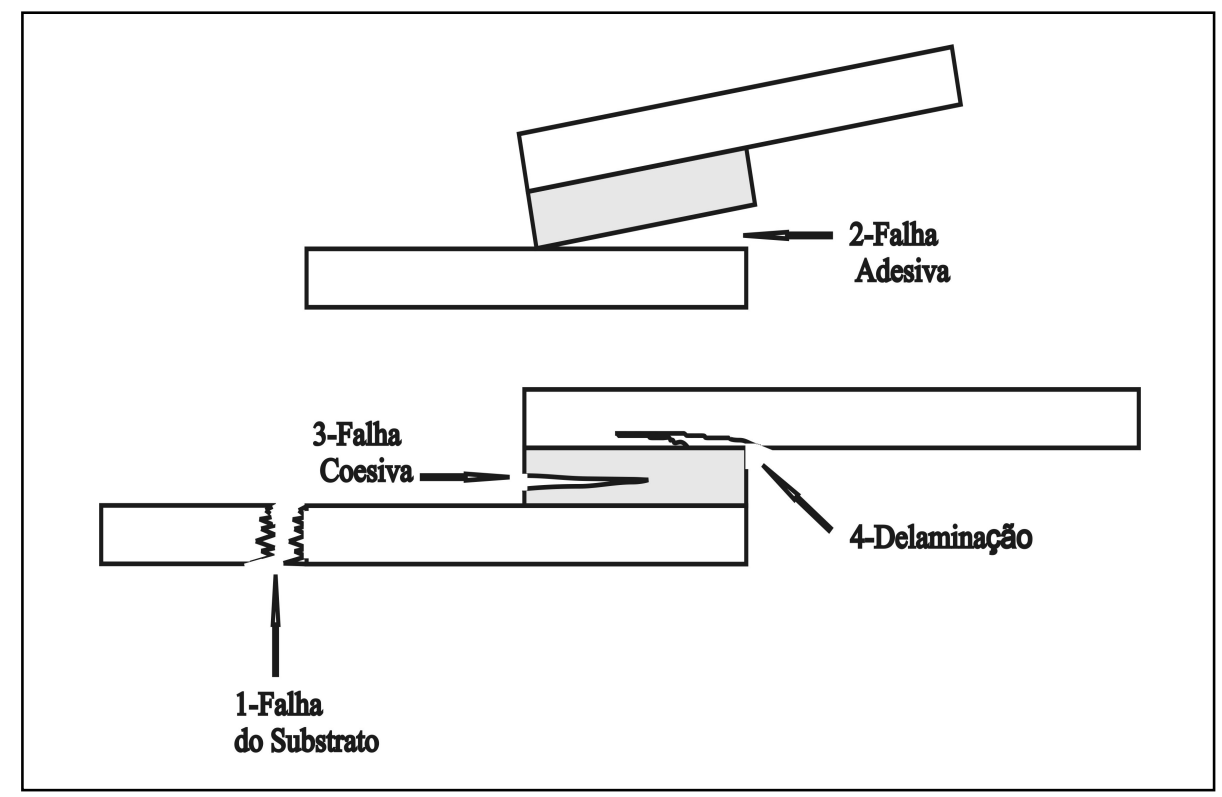

FIGURA 26 - Modos de falha em uma junta submetida ao cisalhamento.

O que determina o modo de falha de um corpo de prova é a diferença entres as forças coesiva, adesiva e a resistência do substrato. A falha ocorrerá primeiramente sobre a menor das forças. Por exemplo, quando a força adesiva for a menor dentre elas, a falha ocorrerá por esse modo, que seria o caso de uma aplicação onde se utilizasse um adesivo que não fosse capaz de interagir de forma eficiente com o substrato. Quando se emprega um adesivo que tenha uma boa interação com o substrato, mas com uma força coesiva pequena, o corpo de prova ao ser submetido ao esforço sofrerá falha coesiva, ou seja, o adesivo romperá ao meio, deixando partes nos dois lados do substrato (Cognard, 2006).

O substrato por sua vez, pode falhar de dois modos: por falha do substrato ou por falha do substrato fora do plano, também chamada de delaminação. Nestes casos também se aplica o conceito anterior, a falha ocorrerá primeiramente por meio da menor resistência. A falha do substrato ocorre quando o corpo de prova submetido ao ensaio de cisalhamento rompe fora da área de colagem. Já a delaminação ocorre quando o corpo de prova resiste à tensão aplicada, porém sofre uma flexão durante o ensaio capaz de iniciar um processo de delaminação, como pode ser observado na FIG. 27.

Nesta ilustração a representação feita em (a) inicialmente nenhuma tensão no corpo de prova, seguida de uma flexão do substrato após a tração, representada em (b). Esse esforço gera pontos de acúmulo de tensão nas extremidades do corpo de prova, conforme ilustração da 
distribuição da tensão em (c). Este acúmulo de tensão ocorre no sentido da clivagem, nas extremidades da região onde se encontra o adesivo, iniciando nesta região o processo de falha.

Os substratos anisotrópicos podem sofrer falha fora da área da colagem ou por delaminação. Os compósitos utilizados neste estudo têm este caráter quasi-isotrópico. Pode-se entender que defeitos no substrato de compósito como bolhas de ar, diferenças de frações de matriz polimérica e reforço e ineficiente impregnação das fibras, favorecem o processo de delaminação, dando início ao um processo de ruptura na região próxima a interface com o adesivo. Substratos compósitos que apresentem menos defeitos tendem a sofrer falha fora da área de colagem.

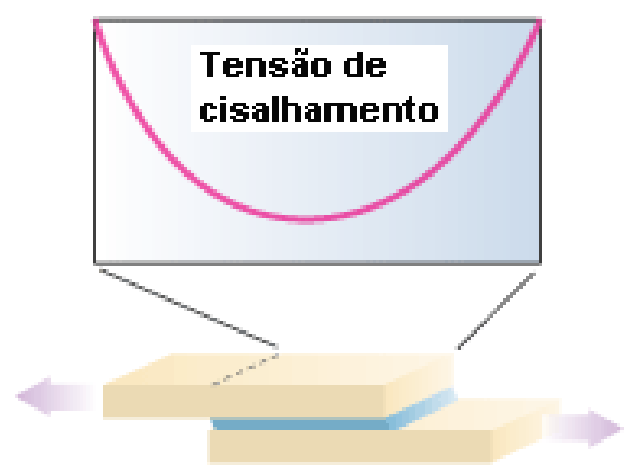

Sentido do deslocameno

FIGURA 27 - Corpo de prova durante ensaio de resistência ao cisalhamento (Specialchem4adhesive, 2005)

Na FIG. 28 observa-se a forma de ruptura no SMC ocorrida por delaminação do substrato de modo interlaminar, pois este compósito foi moldado em uma única camada. As setas na figura indicam a região de delaminação. Durante o ensaio, observou-se que o corpo de prova ao receber o carregamento mecânico, sofreu uma flexão, provocando o início da falha na matriz polimérica, seguido de ruptura das fibras de vidro. Após a separação das duas partes do corpo de prova, pode-se verificar que as fibras de vidro também sofreram ruptura e ficaram expostas. Observou-se na região da fratura a maneira não direcionada que as fibras de vidro foram impregnadas pela matriz polimérica. 


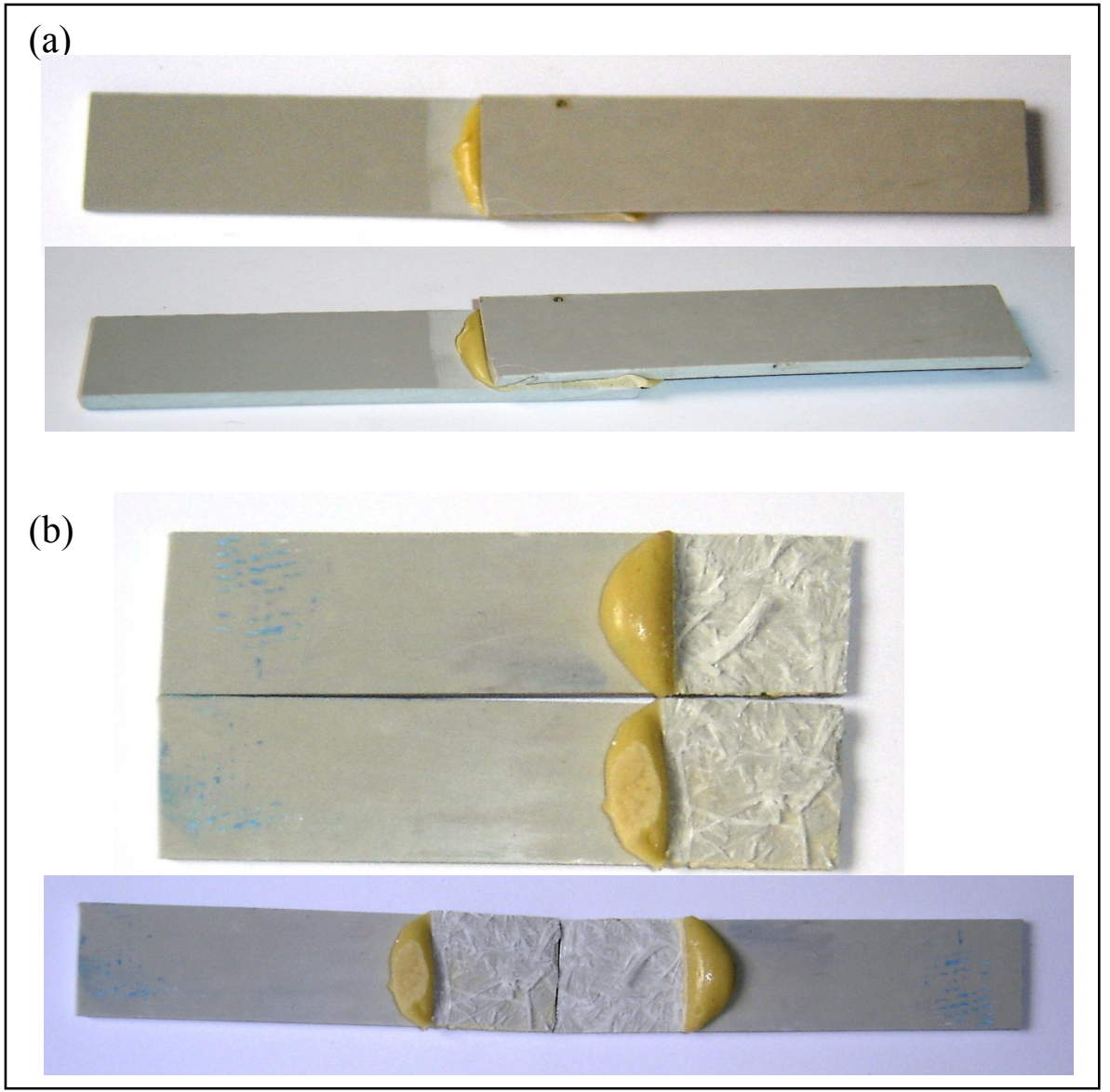

FIGURA 28 - Corpos de prova de SMC no ensaio de cisalhamento do adesivo.

(a) Antes do ensaio, (b) Após ensaio onde as setas indicam a região de delaminação.

No compósito de RTM, conforme FIG. 29, ocorreu falha do substrato, , diferentemente do ocorrido no SMC onde a falha foi por delaminação. Comparando as resistências de ruptura dos substratos de RTM e SMC, apresentadas na TAB.2, têm-se o RTM com 55,4 MPa e o SMC com 37,1 MPa, ou seja, o compósito de RTM apresenta maior tensão de ruptura. Portanto seria esperado que os corpos de prova no ensaio de resistência ao cisalhamento apresentem valores superiores quando houvesse uma ruptura.

O substrato de SMC sofreu flexão e consequente delaminação, enquanto que o de RTM embora tenha apresentado pequena flexão, esta não foi suficiente para iniciar um processo de delaminação, ocorrendo apenas à ruptura do corpo de prova. Os resultados obtidos de

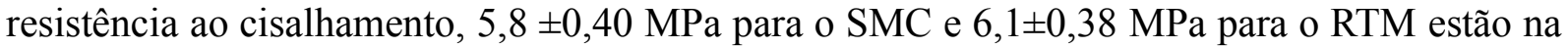
mesma ordem de grandeza e não podem ser comparados como maior ou menor devido à incerteza. 


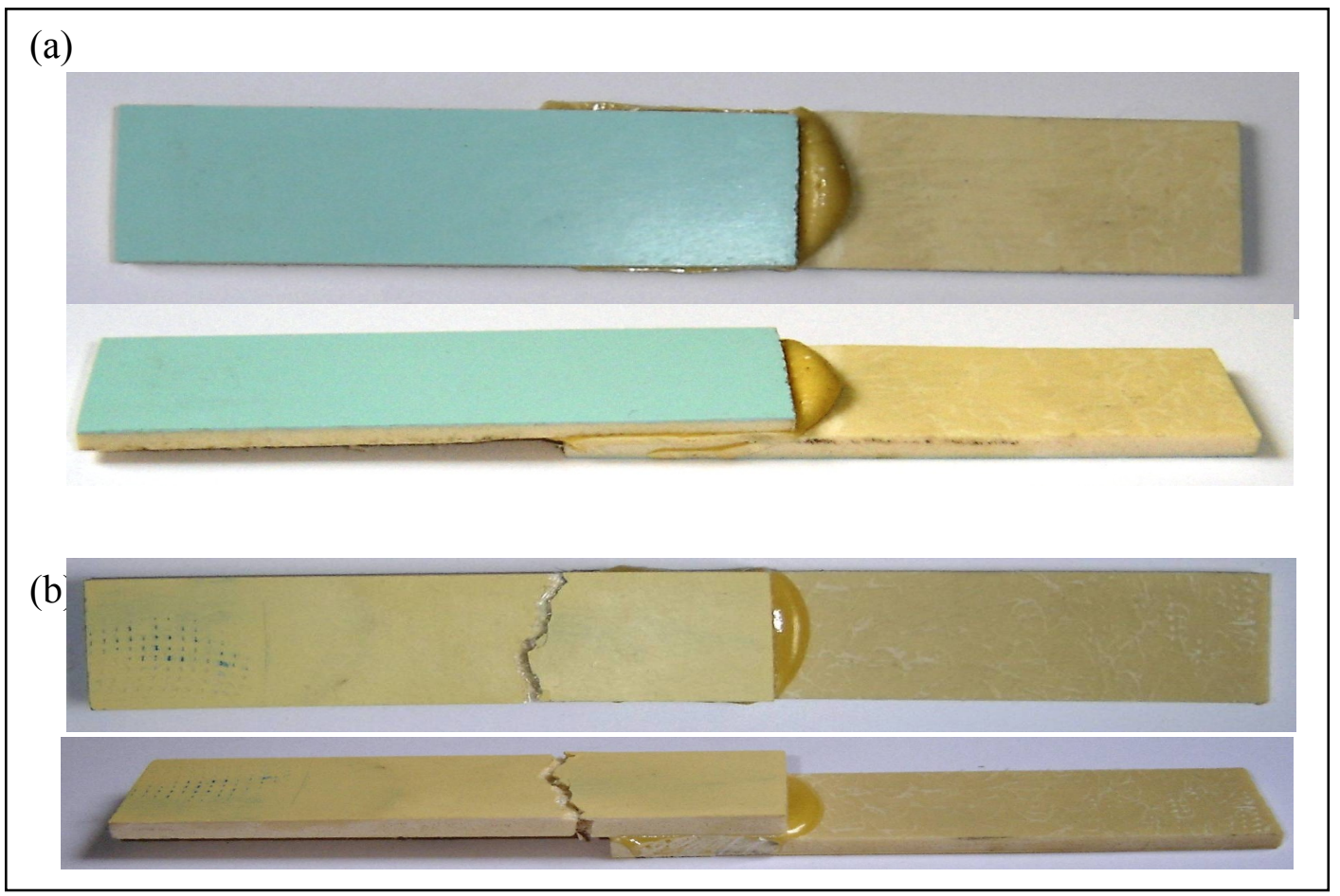

FIGURA 29 - Corpos de prova em RTM no ensaio de cisalhamento do adesivo. (a) Antes do ensaio, (b) Após ensaio onde as setas indicam a posição da ruptura do corpo de prova.

Nos ensaios feitos com substrato de ABS, o modo de falha foi semelhante àquele apresentado pelo substrato de RTM, conforme mostrado na FIG. 30. Observa-se que a fratura foi transversal à direção do carregamento, apresentando uma forma plana com aspecto característico de um ensaio de tração pura. As setas na figura indicam a seção de fratura.

A interação ocorrida do adesivo com o ABS pode ser explicada analisando a composição deste polímero, pois se trata de um material formado por três monômeros: a acrilonitrila (A), o butadieno (B) e o estireno (S). 


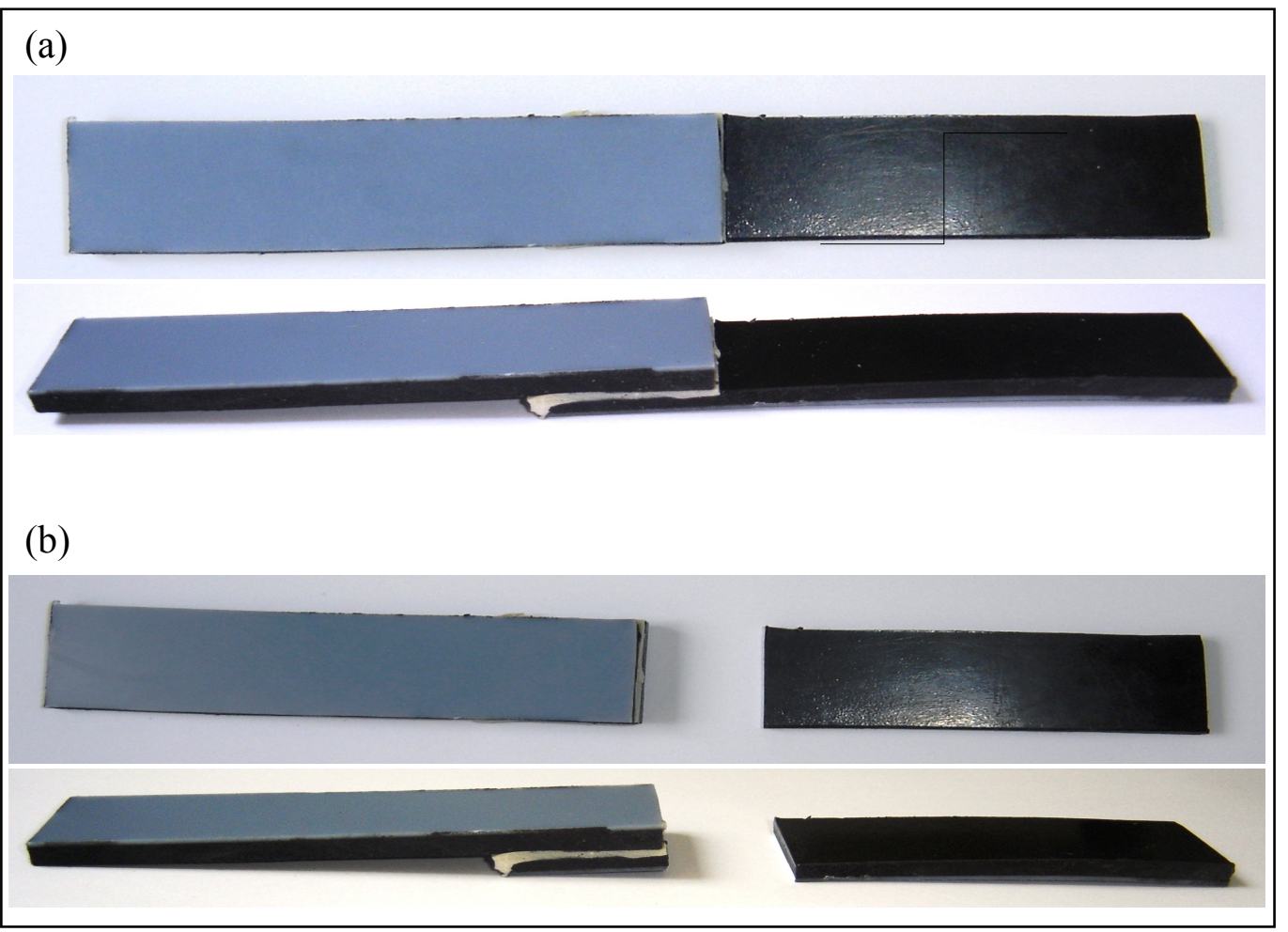

FIGURA 30 - Corpos de prova de ABS no ensaio de cisalhamento do adesivo. (a) antes do ensaio, (b) após ensaio onde as setas indicam a ruptura do corpo de prova.

O butadieno e o estireno são monômeros formados apenas por carbono e hidrogênio e não tem condições de interagir com o adesivo uretânico nas condições de aplicação. O grupo acrilonitrila $\left(\mathrm{H}_{2} \mathrm{C}=\mathrm{CH}-\mathrm{C} \equiv \mathrm{N}\right)$, durante a polimerização reage com o butadieno por meio da quebra da dupla ligação $\mathrm{C}=\mathrm{C}$, ficando o grupo $\mathrm{C} \equiv \mathrm{N}$ disponível para interações com o adesivo. Este grupo pode formar ligações com os hidrogênios das hidroxilas do poliol do adesivo uretânico, tornando assim a interação entre adesivo e substrato muito eficiente. O ABS utilizado neste estudo foi o que apresenta resistência a alta temperatura, que contém maior teor de acrilonitrila (Brady, 2002).

Em muitas aplicações em compósitos onde se faz uso de elementos de reforço e insertos metálicos, principalmente em aplicações náuticas e automotivas, estes metais devem receber um tratamento químico para promover maior resistência à corrosão. Em geral, o aço carbono é o material mais utilizado devido ao menor custo, o processo mais recomendado para essa proteção é a zincagem e cromação preta. Considerando esses aspectos, foram feitos também ensaios de colagem entre substratos de ACZCP. 
A FIG. 31 mostra o modo de ruptura do corpo de prova desse material. Observa-se nesses corpos de prova um resultado superior ao obtido com todos os outros substratos estudados, obtendo-se uma tensão de $10,7 \mathrm{MPa}$ e falha totalmente coesiva. Isto demonstra que a força adesiva, oriunda de uma ótima interação entre o adesivo e o substrato, foi superior à força coesiva do adesivo.

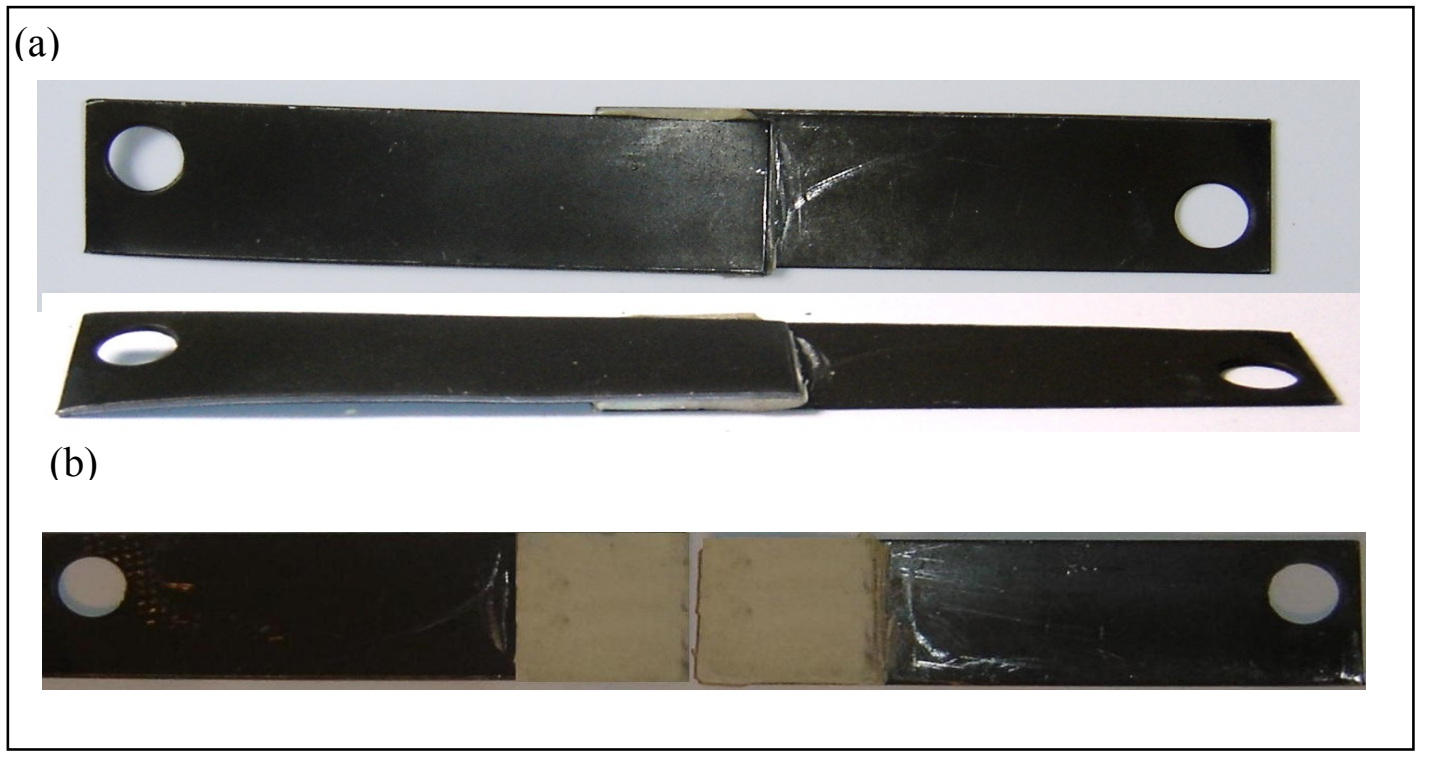

FIGURA 31 - Corpos de prova em ACZCP no ensaio de cisalhamento do adesivo. (a) Antes do ensaio, (b) Após ensaio.

Há que se considerar também que a resistência do aço é muito superior a do adesivo, logo uma falha do substrato não deveria ocorrer, permitindo desse modo, avaliar a resistência adesiva do adesivo uretânico. A interação entre o adesivo e o substrato foi muito eficiente. De fato, o que se observa é uma falha coesiva, que corresponde àquela onde o adesivo rompe, deixando uma camada de adesivo em cada uma das faces do substrato.

As superfícies metálicas, como aços galvanizados, podem apresentar uma série de regiões de composição química diferente e não claramente definidos os limites entre elas, como visto para metais na ilustração da FIG.9. A camada contaminante também dependerá de como o metal foi estocado e manuseado, podendo existir inclusive contaminantes propositalmente adicionados para prevenir corrosão, como óleos e outros inibidores, que também devem ser removidos (Petrie, 2006). O tipo de tratamento na superfície do substrato depende do tipo de substrato, do adesivo utilizado e da resistência mecânica pretendida. 
Algumas vezes utiliza-se o substrato para contato direto com o adesivo, sem nenhuma preparação, pois a superfície já propicia uma camada compatível com o adesivo. Outras vezes, entretanto, dependendo da natureza da aplicação e do substrato, poderá ser necessário uso de abrasão mecânica, primer ou métodos de tratamento químico para ativar a superfície.

\subsection{Efeito das condições externas na resistência ao cisalhamento}

Para o projeto de uma junta adesiva, além das propriedades já avaliadas, é muito importante o conhecimento das condições externas a que a junta estará submetida (Konate, 1994). Variações de temperatura, umidade relativa do ar e substâncias químicas corrosivas são agentes que criam condições que comprometem a integridade do substrato e do adesivo de modo a reduzir a capacidade de carga da junta. Estas condições externas devem ser avaliadas isoladamente e também em uma sequência denominada ciclo, onde se podem simular variações existentes no meio onde a junta será utilizada (Lee, 1987).

As condições externas empregadas neste estudo foram baseadas em normas WSBM11P27B da montadora Ford e a TMS6900 da montadora International Trucks.

A seguir estão os resultados de um amplo estudo feito nos substratos de SMC, RTM, ABS e aço carbono, onde foram aplicados agentes externos envolvendo temperatura, névoa salina, umidade relativa do ar e água destilada. A avaliação foi feita pela análise de resistência ao cisalhamento após exposição, onde a variação percentual em relação a condição de $25^{\circ} \mathrm{C}$ foi utilizada para comparar o efeito causado na junta por essas condições.

\subsubsection{Efeito da temperatura da junta na resistência ao cisalhamento}

É reconhecido que os materiais poliméricos apresentam restrição de uso quando submetidos a condições severas de temperatura, quase sempre sendo estabelecidos limites de temperatura máxima, por exemplo, 170 ou $200^{\circ} \mathrm{C}$. Raramente são determinadas as condições de uso em criogenia, ou seja, temperaturas muito baixas. 
Para a determinação da resistência ao cisalhamento em função da temperatura, os ensaios foram feitos sob cinco condições de temperatura: $-40,25,80,120$ e $177^{\circ} \mathrm{C}$. Como se percebe, há dois extremos importantes: -40 e $177^{\circ} \mathrm{C}$. Os ensaios foram feitos após $24 \mathrm{~h}$ da colagem e um dispositivo de controle da temperatura ao redor da junta foi montado para manter a temperatura da junta durante o ensaio. O ensaio envolvendo temperatura é importante pois permite estabelecer a capacidade máxima da junta de suportar um carregamento mecânico sob diferentes temperaturas.

\subsubsection{Substratos de SMC}

Utilizando substratos de SMC a determinação da resistência ao cisalhamento em função da temperatura foi feita sob as cinco condições anteriormente citadas, os resultados encontram-se na TAB. 5

A resistência ao cisalhamento a $25^{\circ} \mathrm{C}$ representa um parâmetro inicial para ser comparada com os demais valores e será estabelecida como referencia. Esta temperatura está próxima da média ambiente em muitos locais onde o adesivo poderá ser empregado.

TABELA 5 - Resistência ao cisalhamento em corpos de prova de SMC nas temperaturas $-40,25,80,120$ e $177^{\circ} \mathrm{C}$.

\begin{tabular}{ccccc}
\hline $\begin{array}{c}\text { Temperatura } \\
\left({ }^{\circ} \mathrm{C}\right)\end{array}$ & $\begin{array}{c}\text { Resistência ao } \\
\text { cisalhamento }(\mathrm{MPa})\end{array}$ & $\begin{array}{c}\text { Incerteza } \\
\text { expandida }\end{array}$ & Variação $(\%)$ & $\begin{array}{c}\text { Forma de } \\
\text { ruptura }\end{array}$ \\
\hline-40 & 5,6 & 0,40 & $-3,4$ & Delaminação \\
25 & 5,8 & 0,40 & --- & Delaminação \\
80 & 5,2 & 0,32 & $-10,3$ & Delaminação \\
120 & 1,9 & 0,10 & $-67,2$ & Delaminação \\
177 & 0,5 & 0,10 & $-91,4$ & Coesiva \\
\hline
\end{tabular}

Na FIG. 32 é mostrado o comportamento da resistência da junta de substratos de SMC em função da temperatura em ensaios de cisalhamento. 


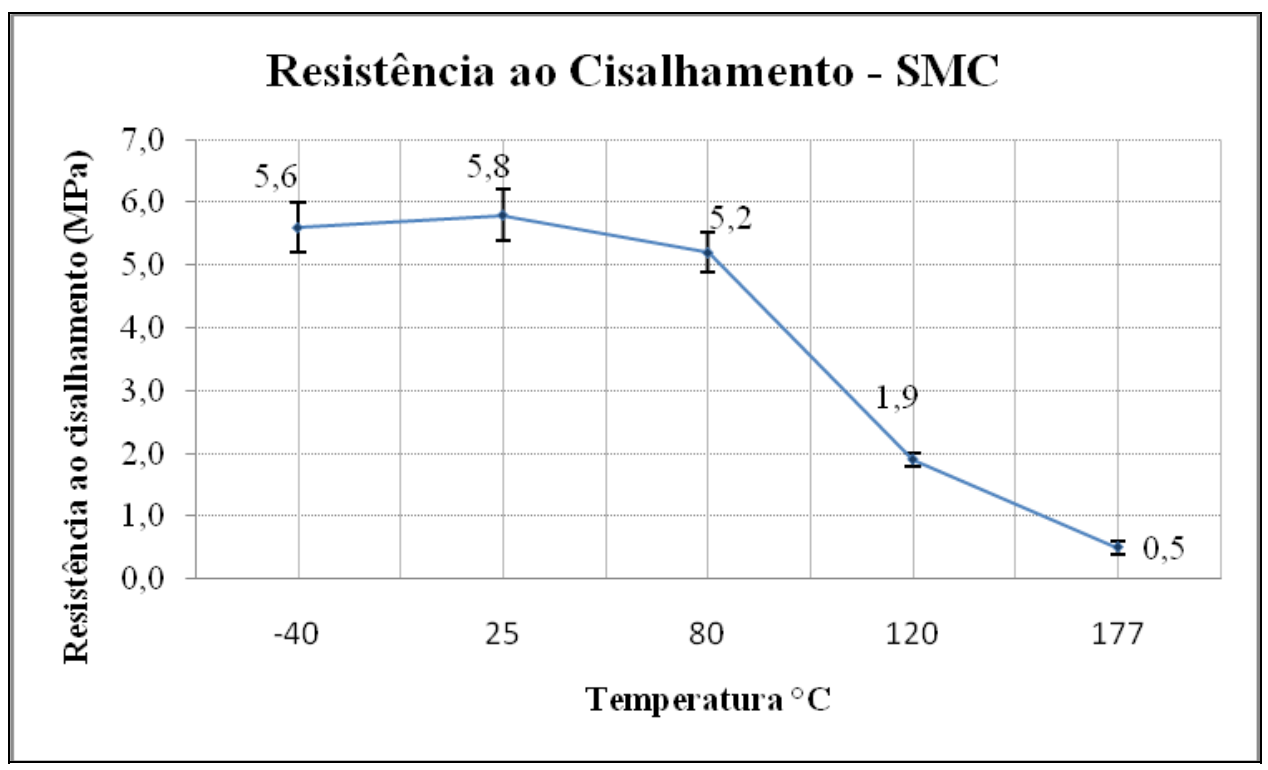

FIGURA 32 - Resistência ao cisalhamento em função da temperatura de corpos de prova de SMC.

$\mathrm{O}$ ensaio realizado a $-40^{\circ} \mathrm{C}$ mostrou uma redução da resistência da junta de $3,4 \%$ quando comparado com aquela a $25^{\circ} \mathrm{C}$, com ocorrência de delaminação do substrato, porém devido à incerteza não foi significativa.

Em todos os ensaios acima de $25^{\circ} \mathrm{C}$ ocorreu um decréscimo da resistência ao cisalhamento. A temperatura de $80^{\circ} \mathrm{C}$ há redução de $10,3 \%$, ocorrendo delaminação do substrato, também não significativa. Porém a $120^{\circ} \mathrm{C}$ a redução foi de $67,2 \%$, com falha por delaminação, o que indica que o substrato teve algum comprometimento nas propriedades devido à temperatura. Para as condições de temperatura a $177^{\circ} \mathrm{C}$ houve falha coesiva, com a junta apresentando resistência de $0,5 \mathrm{MPa}$, o que representa uma redução de $91,4 \%$ da resistência. Como a falha foi coesiva, isto mostra que o adesivo uretânico apresenta limitação para trabalhos contínuos acima desta temperatura.

\subsubsection{Substratos de RTM}

De modo análogo ao SMC, foi feito um estudo utilizando substratos de RTM. Essa análise permitiu comparar o comportamento de juntas formadas por substratos quimicamente semelhantes, porém moldados por diferentes processos. As fibras no RTM são dispostas na forma de mantas, enquanto que no SMC material é formado por uma mistura de fibras picadas 
com resina e cargas minerais. Encontram-se na TAB. 6 os resultados obtidos em juntas de RTM nas temperaturas de $-40,25,80,120$ e $177^{\circ} \mathrm{C}$.

TABELA 6 - Resistência ao cisalhamento de corpos de prova de RTM nas temperaturas de $-40,25,80,120$ e $177^{\circ} \mathrm{C}$.

\begin{tabular}{ccccc}
\hline $\begin{array}{c}\text { Temperatura } \\
\left({ }^{\circ} \mathrm{C}\right)\end{array}$ & $\begin{array}{c}\text { Resistência ao } \\
\text { cisalhamento }(\mathrm{MPa})\end{array}$ & $\begin{array}{c}\text { Incerteza } \\
\text { expandida }\end{array}$ & $\begin{array}{c}\text { Variação } \\
(\%)\end{array}$ & $\begin{array}{c}\text { Forma de } \\
\text { ruptura }\end{array}$ \\
\hline-40 & 5,9 & 0,26 & $-3,3$ & Corpo de prova \\
25 & 6,1 & 0,31 & --- & Corpo de prova \\
80 & 5,0 & 0,22 & $-18,0$ & Corpo de prova \\
120 & 2,1 & 0,12 & $-65,6$ & Corpo de prova \\
177 & 0,4 & 0,10 & $-93,4$ & Coesiva \\
\hline
\end{tabular}

Como aconteceu com o substrato de SMC, a resistência ao cisalhamento a $25^{\circ} \mathrm{C}$ foi usada como parâmetro inicial para ser comparada com os demais valores.

$\mathrm{O}$ ensaio realizado a $-40^{\circ} \mathrm{C}$ mostrou uma redução da resistência ao cisalhamento de $3,3 \%$, com ruptura do corpo de prova, muito próxima a condição de $25^{\circ} \mathrm{C}$.

Novamente, em todas as temperaturas acima de $25^{\circ} \mathrm{C}$ ocorreu um decréscimo da resistência ao cisalhamento. $\mathrm{Na}$ temperatura de $80^{\circ} \mathrm{C}$ houve uma redução de $18 \%$, bem maior do que no SMC. Como a falha foi no corpo de prova, novamente tem-se que o adesivo não foi exigido. Porém a $120^{\circ} \mathrm{C}$ a redução foi pouco menor do que a ocorrida no $\mathrm{SMC}$, com $65,6 \%$, ocorrendo falha por ruptura do corpo de prova, o que indica que o substrato sofreu algum comprometimento nas suas propriedades, que resultou nesta redução. O ensaio realizado a temperatura para $177^{\circ} \mathrm{C}$ apresentou falha coesiva com uma resistência de $0,4 \mathrm{MPa}$, o que representa uma redução expressiva de $93,4 \%$ da resistência. Como a falha foi coesiva, o adesivo uretânico mostrou não ser adequado para trabalhos em temperaturas tão elevadas, a exemplo do que ocorreu com o SMC.

Na FIG. 33 é mostrado o comportamento da resistência ao cisalhamento em função da temperatura para os substratos em RTM 


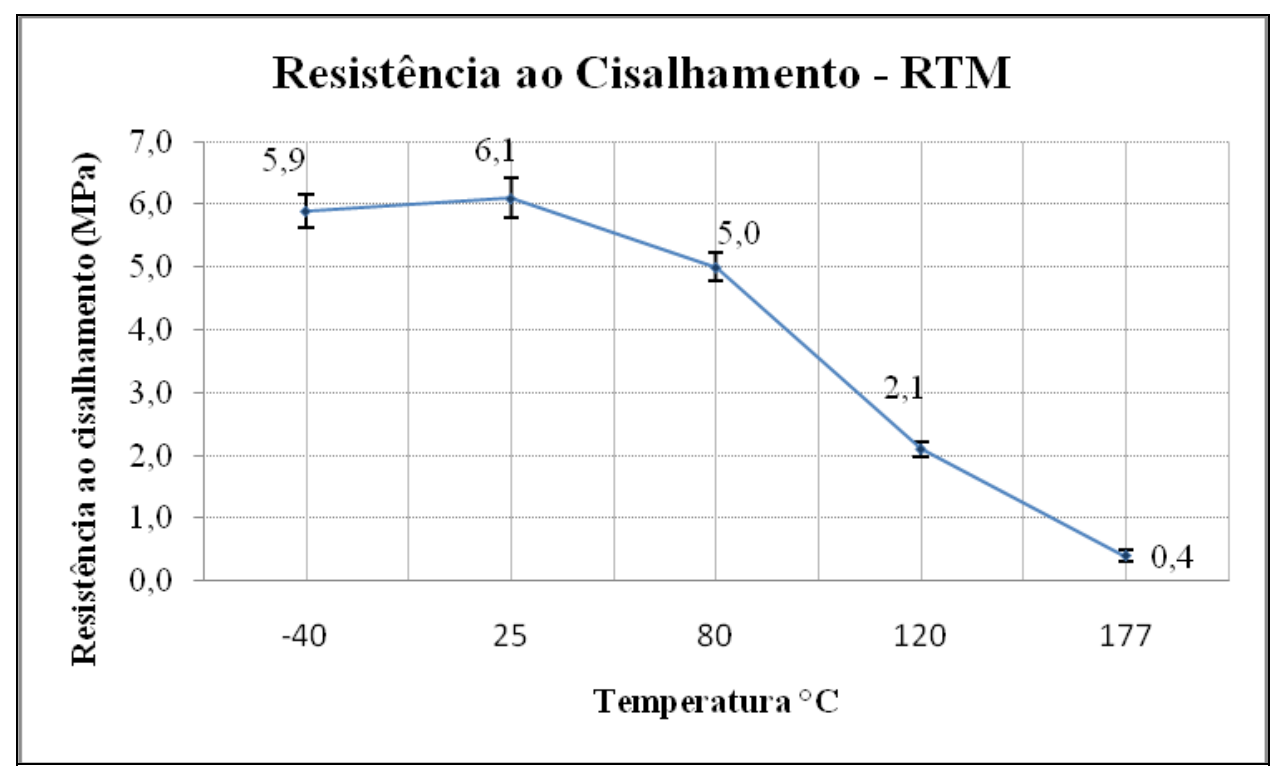

FIGURA 33 - Resistência ao cisalhamento em função da temperatura em corpos de prova em RTM

\subsubsection{Substratos de ABS}

O estudo com corpos de prova em ABS foi feito nas mesmas condições do realizado com os compósitos SMC e RTM, exceto para exposições acima de $120^{\circ} \mathrm{C}$, pois o substrato não resistiria a estas temperaturas. Encontram-se na TAB. 7 os resultados obtidos nas juntas em ABS nas temperaturas $-40,25$ e $80^{\circ} \mathrm{C}$.

TABELA 7 - Resistência ao cisalhamento em corpos de prova de ABS nas temperaturas $-40,25$ e $80^{\circ} \mathrm{C}$.

\begin{tabular}{ccccc}
\hline $\begin{array}{c}\text { Temperatura } \\
\left({ }^{\circ} \mathrm{C}\right)\end{array}$ & $\begin{array}{c}\text { Resistência ao } \\
\text { cisalhamento }(\mathrm{MPa})\end{array}$ & $\begin{array}{c}\text { Incerteza } \\
\text { expandida }\end{array}$ & $\begin{array}{c}\text { Variação } \\
(\%)\end{array}$ & $\begin{array}{c}\text { Forma de } \\
\text { ruptura }\end{array}$ \\
\hline-40 & 3,4 & 0,13 & $-5,6$ & Corpo de prova \\
25 & 3,6 & 0,13 & --- & Corpo de prova \\
80 & 3,6 & 0,12 & 0 & Corpo de prova \\
\hline
\end{tabular}

Na FIG.34 é mostrado o comportamento da resistência ao cisalhamento em função da temperatura para os substratos em ABS. 


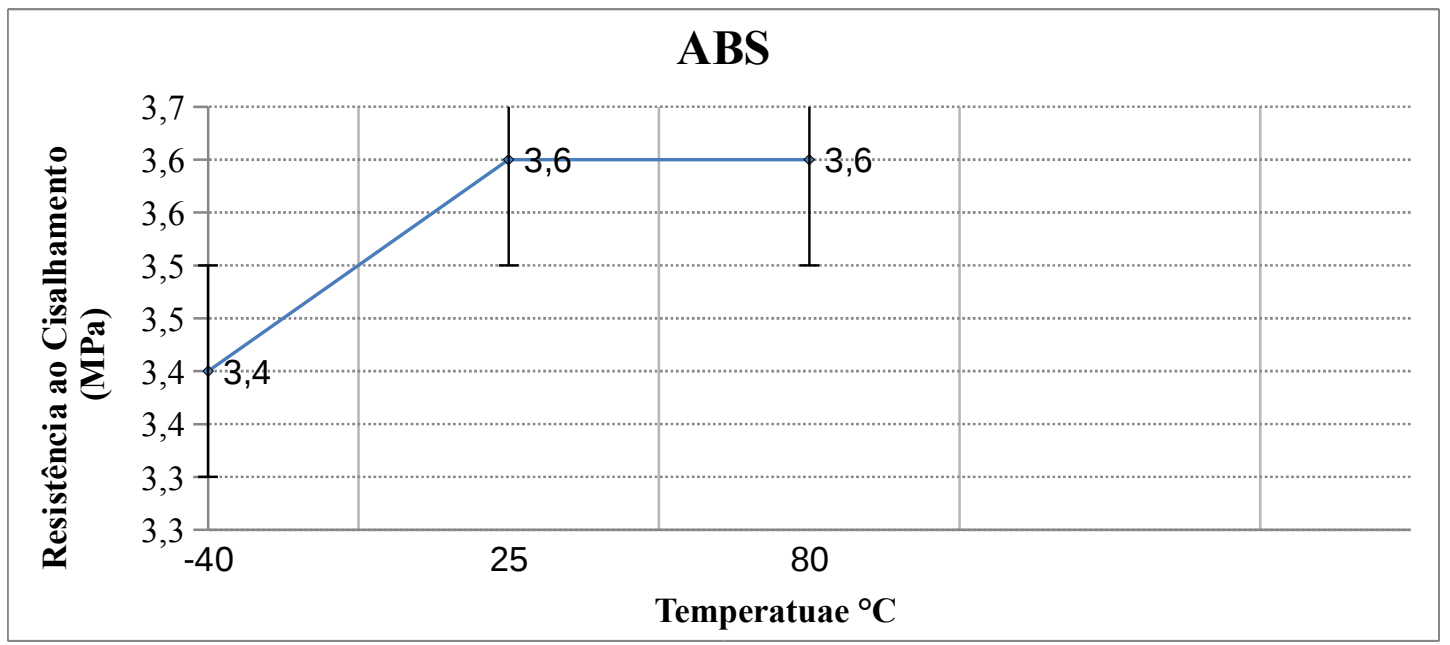

FIGURA 34 - Resistência ao cisalhamento em função da temperatura em corpos de prova em ABS.

$\mathrm{O}$ ensaio realizado a $-40^{\circ} \mathrm{C}$ mostrou uma redução de $5,6 \%$, porém ainda maior do que aquelas registradas para o SMC e RTM com ruptura do corpo de prova. Na temperatura de $80^{\circ} \mathrm{C}$ não houve variação da resistência ao cisalhamento, indicando que nesta temperatura a junta é pouco afetada com aumento da temperatura.

\subsubsection{Substratos de ACZCP}

O estudo foi feito com corpos de prova em ACZCP nas mesmas condições dos ensaios realizados com os compósitos SMC e RTM. Encontram-se na TAB. 8 os resultados obtidos destas juntas nas temperaturas de $-40,25,80,120$ e $177^{\circ} \mathrm{C}$.

Nos corpos de prova de metal pode-se avaliar o efeito da temperatura sobre o adesivo uretânico, pois na faixa de -40 a $177^{\circ} \mathrm{C}$ praticamente não houve variações significativas nas propriedades mecânicas do aço que possam influenciar o comportamento do adesivo. 
TABELA 8 - Resistência ao cisalhamento de corpos de prova em ACZCP nas temperaturas de $-40,25,80,120$ e $177^{\circ} \mathrm{C}$.

\begin{tabular}{ccccc}
\hline $\begin{array}{c}\text { Temperatura } \\
\left({ }^{\circ} \mathrm{C}\right)\end{array}$ & $\begin{array}{c}\text { Resistência ao } \\
\text { cisalhamento }(\mathrm{MPa})\end{array}$ & $\begin{array}{c}\text { Incerteza } \\
\text { expandida }\end{array}$ & $\begin{array}{c}\text { Variação } \\
(\%)\end{array}$ & $\begin{array}{c}\text { Forma de } \\
\text { ruptura }\end{array}$ \\
\hline-40 & 11,7 & 0,50 & 9,5 & Coesiva \\
25 & 10,7 & 0,47 & --- & Coesiva \\
80 & 11,1 & 0,41 & 3,7 & Coesiva \\
120 & 11,3 & 0,50 & 5,5 & Coesiva \\
177 & 0,6 & 0,10 & $-94,2$ & Coesiva \\
\hline
\end{tabular}

O ensaio realizado a $-40^{\circ} \mathrm{C}$, diferentemente do observado nas juntas dos substratos de SMC, RTM e ABS, mostrou um aumento da resistência de 9,5\%, com falha coesiva, porém esta diferença ainda está dentro da incerteza da medição e não pode ser considerada significativa estatisticamente. Nas temperaturas de 80 e $120^{\circ} \mathrm{C}$ foram registrados aumentos $3,7 \%$ e de $5,5 \%$ respectivamente, provavelmente tenham ocorrido reações de pós-cura do adesivo uretânico porém o acréscimo não foi significativo.

$\mathrm{O}$ ensaio realizado a temperatura de $177^{\circ} \mathrm{C}$ apresentou falha coesiva com uma resistência de 0,6MPa, o que representa uma redução de $94,2 \%$ da resistência da junta, resultado bastante semelhante ao observado nas juntas de SMC e RTM, favorecendo a conclusão de que o adesivo uretânico não apresenta resistência coesiva a essa temperatura. $\mathrm{Na}$ FIG.35 é mostrado o comportamento da resistência ao cisalhamento em função da temperatura para os substratos em ACZCP.

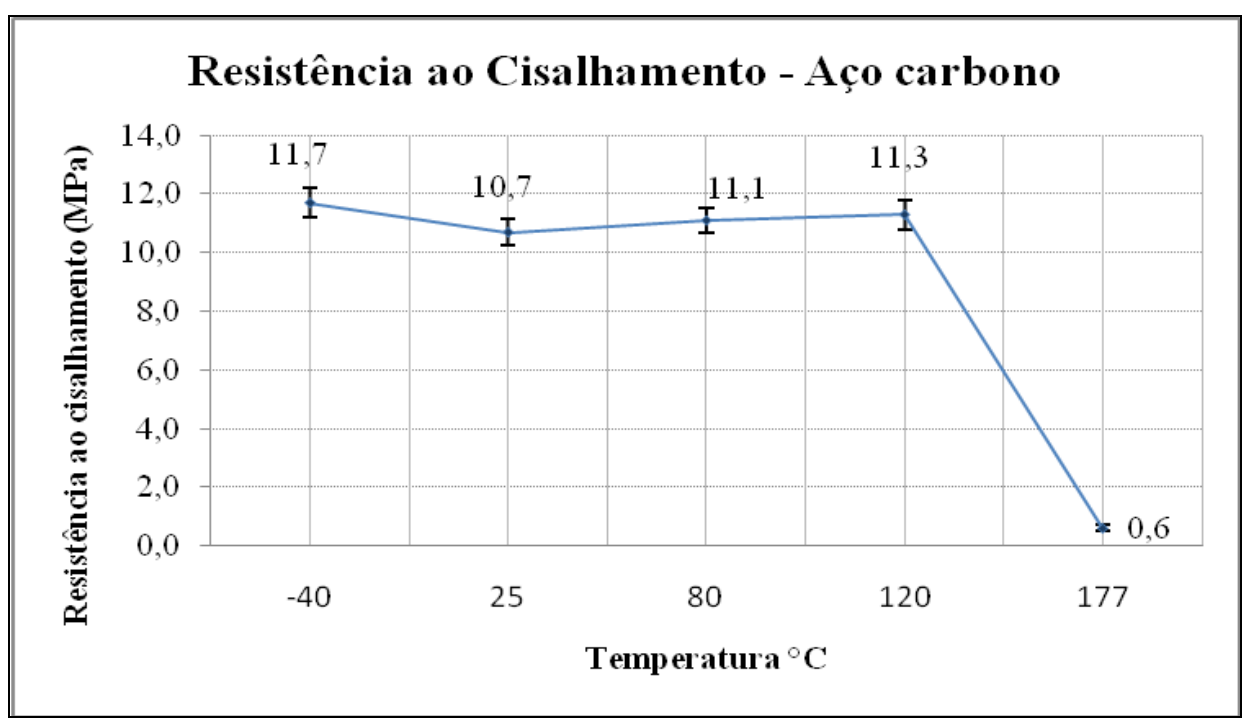

FIGURA 35 - Resistência ao cisalhamento em função da temperatura para ACZCP 


\subsubsection{Efeito da temperatura e tempo de exposição na resistência ao cisalhamento}

Avaliou-se a resistência ao cisalhamento das juntas coladas após a exposição a temperaturas elevadas estabelecidas um período de tempo, seguida de estabilização a temperatura ambiente de $25^{\circ} \mathrm{C}$. Este procedimento teve como intuito avaliar qual a interferência que um pico de temperatura pode exercer nas propriedades mecânicas de uma junta. Duas condições foram avaliadas: condição 1 - exposição por $500 \mathrm{~h}$ a $90^{\circ} \mathrm{C}$, ou seja, um período relativamente longo e a condição $2-20 \mathrm{~min}$ a $177^{\circ} \mathrm{C}$, um período curto e uma temperatura alta. Encontram-se nas TAB. 9 e TAB. 10 os resultados obtidos para as condições 1 e 2 respectivamente nas juntas de SMC, RTM, ABS e ACZCP.

TABELA 9 - Resistência ao cisalhamento em corpos de prova em SMC, RTM, ABS e ACZCP, para a condição 1 - exposição por $500 \mathrm{~h}$ a $90^{\circ} \mathrm{C}$

\begin{tabular}{ccccc}
\hline Substrato & $\begin{array}{c}\text { Resistência ao } \\
\text { cisalhamento }(\mathrm{MPa})\end{array}$ & $\begin{array}{c}\text { Incerteza } \\
\text { expandida }\end{array}$ & $\begin{array}{c}\text { Variação } \\
(\%)\end{array}$ & $\begin{array}{c}\text { Forma de } \\
\text { ruptura }\end{array}$ \\
\hline SMC & 5,5 & 0,43 & $-5,2$ & Corpo de prova \\
RTM & 5,9 & 0,17 & $-3,3$ & Corpo de prova \\
ABS & 3,4 & 0,11 & $-5,6$ & Corpo de prova \\
ACZCP & 11,4 & 0,57 & 6,5 & Coesiva \\
\hline
\end{tabular}

TABELA 10 - Resistência ao cisalhamento em corpos de prova em SMC, RTM, ABS e aço carbono zincado e cromado preto, para a condição 2- exposição por 20min a $177^{\circ} \mathrm{C}$.

\begin{tabular}{ccccc}
\hline Substrato & $\begin{array}{c}\text { Resistência ao } \\
\text { cisalhamento }(\mathrm{MPa})\end{array}$ & $\begin{array}{c}\text { Incerteza } \\
\text { expandida }\end{array}$ & $\begin{array}{c}\text { Variação } \\
(\%)\end{array}$ & $\begin{array}{c}\text { Forma de } \\
\text { ruptura }\end{array}$ \\
\hline SMC & 3,4 & 0,77 & $-41,4$ & Delaminação \\
RTM & 3,2 & 0,56 & $-47,5$ & Delaminação \\
ABS & ------- & --- \\
ACZCP & 13,2 & 0,36 & 23,4 & Coesiva \\
\hline
\end{tabular}

Comparando estes resultados com os obtidos na condição inicial a $25^{\circ} \mathrm{C}$, mostrados na TAB. 4, constata-se que exceto para os corpos de prova em ACZCP, houve uma redução da resistência ao cisalhamento, ocorrência atribuída a um processo de fragilização dos substratos. 
Para o SMC que havia apresentado resistência de $5,8 \pm 0,40 \mathrm{MPa}$ a $25^{\circ} \mathrm{C}$ com falha por delaminação, obteve-se na condição 1 uma redução de 5,2\% com ruptura do corpo de prova. Na condição 2 houve uma redução de 41,4\%, com falha por delaminação. Para o RTM na condição 1 , houve uma redução da resistência ao cisalhamento de 3,3\%, com ruptura do corpo de prova, enquanto que na condição 2 ocorreu uma redução de 47,5\% com falha por delaminação. Pode-se observar que os efeitos das condições 1 e 2 foram muito próximos para ambos os substratos, tanto no sentido de redução da resistência quanto no percentual de redução.

Observa-se que para os substratos de compósitos, quanto maior for à temperatura de exposição, mesmo que por menor tempo, maior será o efeito da redução mecânica sobre a junta. $\mathrm{O}$ efeito da temperatura de $177^{\circ} \mathrm{C}$ por um curto tempo de exposição, apenas $20 \mathrm{~min}$, foi muito mais deletéria do que uma exposição longa, 500h, a uma temperatura menor de $90^{\circ} \mathrm{C}$.

Nos substratos de $\mathrm{ABS}$ não foi possível avaliar o comportamento a $177^{\circ} \mathrm{C}$ devido à resistência a fusão deste material ser inferior a temperatura do ensaio. Apenas avaliou-se na condição 1 , onde houve uma redução de 5,6\% com ruptura do corpo de prova, estando assim mais próximo ao comportamento do SMC.

Nos substratos de ACZCP, que apresentam uma resistência a mecânica muito superior ao do adesivo uretânico, foi possível avaliar isoladamente o comportamento mecânico do adesivo sem as interferências ocorridas nos substratos poliméricos, como por exemplo, delaminação e ruptura do substrato. Os resultados de resistência ao cisalhamento mostram que nas condições 1 e 2, ao invés de tornarem o adesivo menos resistente, houve um efeito contrário, ou seja, tornaram-no ainda mais resistente, com um aumento de 6,5\% para a condição 1 e 23,4\% para a condição 2, o que indica que um processo de pós-cura deve ter ocorrido à temperatura mais elevada e desta forma melhorado seu desempenho. Também é importante observar que no ensaio feito à temperatura de $177^{\circ} \mathrm{C}$, mostrado na TAB.8, a resistência ao cisalhamento foi bastante reduzida, porém aqui se deve destacar que o adesivo tem capacidade de resistir a um pico de temperatura de $177^{\circ} \mathrm{C}$ por $20 \mathrm{~min}$, sem perder sua resistência ao cisalhamento. 


\subsubsection{Efeito da temperatura, tempo e umidade relativa na resistência ao} cisalhamento

A presença de umidade relativa do ar pode iniciar um processo de hidrólise e degradação em muitos materiais poliméricos. Deste modo, é importante avaliar o efeito da umidade combinada com diferentes temperaturas em juntas expostas a estas condições, possibilitando prever futuras ocorrências quando da junta em uso.

A resistência ao cisalhamento foi feita após a exposição nas condições 1- exposição por $500 \mathrm{~h}$ a $25^{\circ} \mathrm{C}$ e $98 \%$ de umidade relativa e condição 2 - exposição por $500 \mathrm{~h}$ a $38^{\circ} \mathrm{C}$ e $98 \%$ de umidade relativa. Encontram-se nas TAB. 11 e TAB. 12 os resultados obtidos para juntas de SMC, RTM, ABS e ACZCP temperaturas nas condições acima citadas.

TABELA 11 - Resistência ao cisalhamento em corpos de prova em SMC, RTM, ABS e aço carbono zincado e cromado preto, expostos na condição 1- exposição por $500 \mathrm{~h}$ a $25^{\circ} \mathrm{C}$ e $98 \%$ de umidade relativa.

\begin{tabular}{ccccc}
\hline Substrato & $\begin{array}{c}\text { Resistência ao } \\
\text { cisalhamento }(\mathrm{MPa})\end{array}$ & $\begin{array}{c}\text { Incerteza } \\
\text { expandida }\end{array}$ & $\begin{array}{c}\text { Variação } \\
(\%)\end{array}$ & $\begin{array}{c}\text { Forma de } \\
\text { ruptura }\end{array}$ \\
\hline SMC & 5,3 & 0,25 & $-8,6$ & Corpo de prova \\
RTM & 5,7 & 0,23 & $-6,6$ & Corpo de prova \\
ABS & 3,3 & 0,10 & $-8,3$ & Corpo de prova \\
ACZCP & 10,5 & 0,49 & $-1,9$ & Coesiva \\
\hline
\end{tabular}

Para todos os corpos de prova de substratos poliméricos, SMC, RTM e ABS, é possível identificar uma redução da resistência ao cisalhamento, sempre com falha no substrato, quando comparado com os obtidos na condição inicial a $25^{\circ} \mathrm{C}$, mostrado na TAB. 4 , o que também indica a ocorrência de um processo de fragilização destes substratos.

Para o SMC na condição 1, houve uma redução de 8,6\% com ruptura do corpo de prova e na condição 2 uma redução de 44,8\% com delaminação. Para o RTM na condição 1 ocorreu uma redução de 6,6\% com ruptura do corpo de prova e na condição 2 uma redução de 47,5\% com delaminação. Nos substratos compósitos observa-se que o comportamento de redução da resistência ao cisalhamento foi semelhante na forma de ruptura e também no percentual de redução, além disse nota-se que o efeito combinado da exposição à temperatura com umidade relativa reduz significativamente a resistência ao cisalhamento da junta para estes materiais compósitos. 
Nos substratos de ABS a exposição à condição 1 levou a uma redução de 8,3\% na resistência ao cisalhamento, enquanto que a condição 2 levou a uma redução de $33,3 \%$. O comportamento do ABS nestas duas condições foi bastante semelhante ao observado nos substratos compósitos.

TABELA 12 - Resistência ao cisalhamento em corpos de prova em SMC, RTM, ABS e ACZCP, expostos na condição 2- exposição por $500 \mathrm{~h}$ a $38^{\circ} \mathrm{C}$ e $98 \%$ de umidade relativa.

\begin{tabular}{ccccc}
\hline Substrato & $\begin{array}{c}\text { Resistência ao } \\
\text { cisalhamento }(\mathrm{MPa})\end{array}$ & $\begin{array}{c}\text { Incerteza } \\
\text { expandida }\end{array}$ & $\begin{array}{c}\text { Variação } \\
(\%)\end{array}$ & $\begin{array}{c}\text { Forma de } \\
\text { ruptura }\end{array}$ \\
\hline SMC & 3,2 & 0,41 & $-44,8$ & Delaminação \\
RTM & 3,2 & 0,29 & $-47,5$ & Delaminação \\
ABS & 2,4 & 0,12 & $-33,3$ & Corpo de prova \\
ACZCP & 11,1 & 0,50 & 3,7 & Coesiva \\
\hline
\end{tabular}

Nos substratos de ACZCP apesar do efeito da umidade relativa sobre o adesivo uretânico ser limitada as bordas laterais, ela verdadeiramente ocorre, mas de modo reduzido, pois grande parte da área de contato do adesivo está protegida pelo substrato.

Os resultados de resistência ao cisalhamento mostram que na condição 1 houve uma redução de $1,9 \%$, enquanto que na condição 2 ocorreu um aumento de $3,7 \%$ ambos com falha coesiva. Isto demonstra que na temperatura ambiente, a umidade relativa exerceu pouco efeito sobre o adesivo. Entretanto combinados umidade relativa e temperatura de $38^{\circ} \mathrm{C}$, apesar da pequena elevação de temperatura, ocorreu uma pós cura no adesivo, ação que o torna mais resistente.

\subsubsection{Efeito da imersão em água destilada na resistência ao cisalhamento}

A imersão dos materiais poliméricos em água também pode iniciar um processo de hidrólise e corrosão e reduzir a resistência de uma junta, tanto por efeito no substrato quanto no adesivo uretânico. Esta condição poderá ocorrer em uma situação prática como no caso de peças de carenagem de veículos onde internamente são colados os insertos metálicos com o adesivo estrutural. Estas peças podem molhar ou pela ação de chuvas ou mesmo em caso de limpeza. Assim avaliou-se este efeito em juntas formadas por SMC, RTM, ABS e ACZCP cujos resultados encontram-se na TAB.13. 
Os corpos de prova foram imersos em água destilada a $25^{\circ} \mathrm{C}$ por $500 \mathrm{~h}$, seguidos por secagem manual com papel absorvente e ensaiados para obter-se a resistência ao cisalhamento. O emprego de água destilada ao invés de água de abastecimento deve-se a uma padronização de ensaio, pois se sabe que dependendo do local a composição de sais dissolvidos na água de abastecimento pode variar significativamente.

De modo semelhante ao ocorrido com as juntas expostas à umidade relativa, os corpos de prova dos substratos poliméricos, SMC, RTM e ABS, apresentaram uma redução da resistência ao cisalhamento, sempre com falha no substrato, quando comparado com os obtidos na condição inicial a $25^{\circ} \mathrm{C}$, mostrado na TAB. 4 , o que também indica que ocorreu um processo de fragilização destes substratos.

Os corpos de prova dos substratos de SMC e RTM sofreram respectivamente uma redução da resistência ao cisalhamento de $19,0 \%$, e 16,4\%, enquanto que os de ABS a redução foi de $13,9 \%$, todos com ruptura do corpo de prova.

TABELA 13 - Resistência ao cisalhamento em corpos de prova em SMC, RTM, ABS e aço carbono após $500 \mathrm{~h}$ de imersão em água destilada a $25^{\circ} \mathrm{C}$.

\begin{tabular}{ccccc}
\hline Substrato & $\begin{array}{c}\text { Resistência ao } \\
\text { cisalhamento }(\mathrm{MPa})\end{array}$ & $\begin{array}{c}\text { Incerteza } \\
\text { expandida }\end{array}$ & $\begin{array}{c}\text { Variação } \\
(\%)\end{array}$ & $\begin{array}{c}\text { Forma de } \\
\text { ruptura }\end{array}$ \\
\hline SMC & 4,7 & 0,32 & $-19,0$ & Corpo de prova \\
RTM & 5,1 & 0,35 & $-16,4$ & Corpo de prova \\
ABS & 3,1 & 0,20 & $-13,9$ & Corpo de prova \\
ACZCP & 11,0 & 0,68 & 2,8 & Coesiva \\
\hline
\end{tabular}

Diferentemente das juntas em materiais poliméricos, naquelas que utilizaram ACZCP ocorreu um aumento da resistência ao cisalhamento da ordem de $2,8 \%$, mas que não pode ser considerado estatisticamente como uma elevação da resistência, lembrando que neste caso o adesivo uretânico esteve parcialmente protegido do contato com a água destilada. Isto demonstra que o adesivo uretânico praticamente não foi afetado com a imersão em água destilada e confirma que a redução da resistência ao cisalhamento nas juntas de materiais poliméricos se deve à perda de resistência mecânica dos substratos. 


\subsubsection{Efeito da névoa salina na resistência ao cisalhamento}

Uma das condições mais críticas para promover degradação de materiais poliméricos ou corrosão de materiais metálicos e que pode afetar a resistência dos materiais é a exposição à névoa salina. Devido à presença de sais minerais, a névoa salina consegue aliar o efeito corrosivo dos sais minerais com a umidade, de forma a reduzir a vida útil de muitos materiais sob esta condição. Avaliou-se o efeito isolado da névoa salina sobre as juntas anteriormente citadas após exposição por 240 e 500h conforme procedimentos da norma ABNT NBR 8094. Os resultados obtidos do ensaio são mostrados nas TAB.13 e TAB.14.

Observou-se uma redução da resistência ao cisalhamento para todas as juntas quando comparados com os resultados obtidos na condição inicial a $25^{\circ} \mathrm{C}$, mostrado na TAB. 4 . Os corpos de prova em SMC e RTM apresentaram reduções próximas após exposições a 240h, e $500 \mathrm{~h}$, sendo que após $240 \mathrm{~h}$ foram de 34,8\% para o SMC e 39,2\% para o RTM e após 500h as reduções foram de 45,9\% para o SMC e de 46,8\% para o RTM. Para os corpos de prova em ABS as reduções foram $38,9 \%$ após $240 \mathrm{~h}$ de exposição e de $42,2 \%$ após $500 \mathrm{~h}$. As reduções observadas nestes substratos poliméricos foram oriundas da corrosão ocorrida na exposição da névoa salina que combina temperatura de $35^{\circ} \mathrm{C}$ com presença de umidade e efeito corrosivo do sal $\mathrm{NaCl}$ utilizado na solução.

TABELA 13 - Resistência ao cisalhamento em corpos de prova em SMC, RTM, ABS e ACZCP após exposição de $240 \mathrm{~h}$ em névoa salina.

\begin{tabular}{ccccc}
\hline Substrato & $\begin{array}{c}\text { Resistência ao } \\
\text { cisalhamento }(\mathrm{MPa})\end{array}$ & $\begin{array}{c}\text { Incerteza } \\
\text { expandida }\end{array}$ & $\begin{array}{c}\text { Variação } \\
(\%)\end{array}$ & $\begin{array}{c}\text { Forma de } \\
\text { ruptura }\end{array}$ \\
\hline SMC & 3,8 & 0,46 & $-34,8$ & Delaminação \\
RTM & 3,7 & 0,60 & $-39,2$ & Delaminação \\
ABS & 2,2 & 0,20 & $-38,9$ & Corpo de prova \\
ACZCP & 10,6 & 0,68 & $-0,5$ & Coesiva \\
\hline
\end{tabular}

Nos corpos de prova em ACZCP as reduções foram menores, apenas 0,5\% após 240h de exposição e de $1,5 \%$ de $500 \mathrm{~h}$. Nesta última deu-se pela perda de resistência do adesivo, uma vez que o substrato não sofreu significativa corrosão nestas exposições. As reduções observadas, no entanto, foram relativamente pequenas devido a pouca exposição que o adesivo que ocorre apenas nas laterais do corpo de prova. 
TABELA 14 - Resistência ao cisalhamento em corpos de prova em SMC, RTM, ABS e aço carbono zincado e cromado preto após exposição de 500h em névoa salina.

\begin{tabular}{ccccc}
\hline Substrato & $\begin{array}{c}\text { Resistência ao } \\
\text { cisalhamento }(\mathrm{MPa})\end{array}$ & $\begin{array}{c}\text { Incerteza } \\
\text { expandida }\end{array}$ & $\begin{array}{c}\text { Variação } \\
(\%)\end{array}$ & $\begin{array}{c}\text { Forma de } \\
\text { ruptura }\end{array}$ \\
\hline SMC & 3,1 & 0,39 & $-45,9$ & Delaminação \\
RTM & 3,2 & 0,33 & $-46,8$ & Delaminação \\
ABS & 2,1 & 0,11 & $-42,2$ & Corpo de prova \\
ACZCP & 10,5 & 0,54 & $-1,5$ & Coesiva \\
\hline
\end{tabular}

7.4.6. Efeito combinado de temperatura, tempo, umidade e névoa salina na resistência ao cisalhamento

Estas condições externas foram avaliadas separadamente nos itens anteriores. Contudo, a ação conjunta dessas condições necessitam ser avaliadas e duas sequencias foram selecionadas, baseadas em normas automotivas para adesivos estruturais, que são denominadas ciclos. No ciclo 1 as juntas foram submetidas a $25^{\circ} \mathrm{C}$ por $16 \mathrm{~h}$ com $98 \%$ de umidade relativa (UR), seguida de exposição a $-30^{\circ} \mathrm{C}$ por $2 \mathrm{~h}$ e a $25^{\circ} \mathrm{C}$ por $2 \mathrm{~h}$. Após estas etapas, as juntas foram colocadas sob ação de névoa salina por $2 \mathrm{~h}$, seguida de exposição a $70^{\circ} \mathrm{C}$ por $2 \mathrm{~h}$. Esse ciclo foi repetido 42 vezes. No ciclo 2 as juntas foram submetidas também a $16 \mathrm{~h}$ de UR mas a $38^{\circ} \mathrm{C}$, seguida por $4 \mathrm{~h}$ a $-40^{\circ} \mathrm{C}$ e a $4 \mathrm{~h}$ a $90^{\circ} \mathrm{C}$. A TAB. 15 resume os dois ciclos, cujos resultados estão contidos nas TAB. 16 e TAB. 17.

TABELA 15 - Ciclos de exposição.

\begin{tabular}{cc}
\hline Ciclo 1 & Ciclo 2 \\
\hline $16 \mathrm{~h} / 25^{\circ} \mathrm{C} / 98 \%$ UR & $16 \mathrm{~h} / 38^{\circ} \mathrm{C}$ e $98 \% \mathrm{UR}$ \\
$2 \mathrm{~h} /-30^{\circ} \mathrm{C}$ & $4 \mathrm{~h} /-40^{\circ} \mathrm{C}$ \\
$2 \mathrm{~h} / 25^{\circ} \mathrm{C}$ & $4 \mathrm{~h} / 90^{\circ} \mathrm{C}$ \\
$2 \mathrm{~h}$ sob névoa salina & --- \\
$2 \mathrm{~h} / 70^{\circ} \mathrm{C}$ & --- \\
42 vezes & 10 vezes \\
\hline
\end{tabular}


TABELA 16 - Resistência ao cisalhamento em corpos de prova em SMC, RTM, ABS e aço carbono zincado e cromado preto exposto ao ciclo 1.

\begin{tabular}{ccccc}
\hline Substrato & $\begin{array}{c}\text { Resistência ao } \\
\text { cisalhamento }(\mathrm{MPa})\end{array}$ & $\begin{array}{c}\text { Incerteza } \\
\text { expandida }\end{array}$ & $\begin{array}{c}\text { Variação } \\
(\%)\end{array}$ & $\begin{array}{c}\text { Forma de } \\
\text { ruptura }\end{array}$ \\
\hline SMC & 4,7 & 0,40 & $-19,0$ & Delaminação \\
RTM & 5,1 & 0,33 & $-16,4$ & Corpo de prova \\
ABS & 3,0 & 0,10 & $-16,7$ & Corpo de prova \\
ACZCP & 10,5 & 0,72 & $-1,9$ & Coesiva \\
\hline
\end{tabular}

TABELA 17 - Resistência ao cisalhamento em corpos de prova em SMC, RTM, ABS e aço carbono zincado e cromado preto exposto ao ciclo 2.

\begin{tabular}{ccccc}
\hline Substrato & $\begin{array}{c}\text { Resistência ao } \\
\text { cisalhamento }(\mathrm{MPa})\end{array}$ & $\begin{array}{c}\text { Incerteza } \\
\text { expandida }\end{array}$ & $\begin{array}{c}\text { Variação } \\
(\%)\end{array}$ & $\begin{array}{c}\text { Forma de } \\
\text { ruptura }\end{array}$ \\
\hline SMC & 5,2 & 0,45 & $-10,3$ & Delaminação \\
RTM & 5,3 & 0,30 & $-13,1$ & Delaminação \\
ABS & 3,4 & 0,11 & $-5,6$ & Corpo de prova \\
ACZCP & 12,1 & 0,81 & 13,1 & Coesiva \\
\hline
\end{tabular}

A exposição ao ciclo 1 resultou na redução da resistência ao cisalhamento de todos os corpos de prova. Para os corpos de prova dos substratos poliméricos, a redução foi de 19,0\% para o SMC, $16,4 \%$ para o RTM e $16,7 \%$ para o ABS, todos os três com falha do corpo de prova. Para os corpos de prova em ACZCP a redução foi menor, apenas 1,9\%. No ciclo 2 houve redução em todos os corpos de prova exceto os de ACZCP. Para os corpos de prova dos substratos poliméricos a redução foi de $10,3 \%$ para o SMC, 13,1\% para o RTM e 5,6\% para o ABS, todos os três também com falha do corpo de prova. Ao contrário dos demais para os de ACZCP houve um aumento de 13,1\%.

Pode-se observar que o ciclo 1 teve um efeito mais agressivo na redução da resistência da junta. Isto se deve ao maior numero de repetições do ciclo além da presença da névoa salina, que foi a condição que isoladamente causou maior redução da resistência ao cisalhamento. $\mathrm{O}$ única caso em que houve aumento foi no ACZCP no ciclo 2 devido a pós cura do adesivo e ausência do efeito deletério da névoa salina. 


\subsubsection{Comparação do efeito das condições externas}

Os dados na TAB.18 mostram o efeito das condições externas nas as juntas estudadas, estabelecendo uma comparação percentual com os ensaios feitos a $25^{\circ} \mathrm{C}$. Para uma melhor visualização a FIG.36 apresenta esta comparação na forma de um gráfico de barras.

$\mathrm{O}$ efeito das temperaturas $-40,80$ e $120^{\circ} \mathrm{C}$ nas juntas de $\mathrm{SMC}$, RTM e ABS, tiveram como consequência uma redução da resistência ao cisalhamento devido ao comprometimento do substrato. Isto pôde ser confirmado pelo modo de falha que ocorreu nos corpos de prova, que foram por ruptura do substrato ou por delaminação.

Nas juntas do substrato de ACZCP a resistência ao cisalhamento aumentou nas temperaturas $-40,80$ e $120^{\circ} \mathrm{C}$. Já na temperatura de $177^{\circ} \mathrm{C}$ o adesivo sofreu um comprometimento de sua resistência em todas as juntas, evidenciado pela falha coesiva ocorrida com cerca de $90 \%$ de redução da resistência ao cisalhamento, considerada a condição que provoca maior degradação dos materiais poliméricos.

Exposições às temperaturas de $90^{\circ} \mathrm{C}$ e $177^{\circ} \mathrm{C}$ associados com o tempo e após estabilização à temperatura de $25^{\circ} \mathrm{C}$, resultaram também em uma redução da resistência ao cisalhamento das juntas de SMC, RTM e ABS, porém em menor proporção do que aquela obtida quando a junta foi ensaiada nas temperaturas de $80^{\circ} \mathrm{C}$ e $177^{\circ} \mathrm{C}$.

As mesmas exposições a $90^{\circ} \mathrm{C}$ e $177^{\circ} \mathrm{C}$ associados com o tempo e após estabilização à temperatura de $25^{\circ} \mathrm{C}$ para a junta metálica mostrou um aumento da resistência, indicando que o adesivo uretânico sofreu um processo de pós-cura que proporcionou uma melhora de seu desempenho. Também foi possível observar que um pequeno tempo de exposição a $177^{\circ} \mathrm{C}$ não foi capaz de comprometer o adesivo uretânico.

A avaliação do efeito da umidade relativa à temperatura de $25^{\circ} \mathrm{C}$ mostrou uma redução na resistência ao cisalhamento em todas as juntas, porém quando a exposição à umidade relativa se deu a $38^{\circ} \mathrm{C}$, houve um aumento na resistência ao cisalhamento no aço carbono, isto ocorreu devido a um processo de pós-cura no adesivo e porque devido ao desenho da junta o adesivo ficou protegido pelo substrato. 
TABELA 18 - Comparação da variação percentual da resistência ao cisalhamento nos corpos de prova de SMC, RTM, ABS e ACZCP, em relação aos resultados obtidos na condição a $25^{\circ} \mathrm{C}$.

\begin{tabular}{ccccc}
\hline & \multicolumn{5}{c}{ Variação percentual nos substratos (\%) } \\
\hline Condições de exposição & SMC & RTM & ABS & Aço carbono \\
$-40^{\circ} \mathrm{C}$ & $-3,4$ & $-3,3$ & $-5,6$ & 9,5 \\
$80^{\circ} \mathrm{C}$ & $-10,3$ & $-18,0$ & 0,0 & 3,7 \\
$120^{\circ} \mathrm{C}$ & $-67,2$ & $-65,6$ & --- & 5,5 \\
$177^{\circ} \mathrm{C}$ & $-91,4$ & $-93,4$ & --- & $-94,2$ \\
$500 \mathrm{~h}$ a $90^{\circ} \mathrm{C}$ & $-5,2$ & $-3,3$ & $-5,6$ & 6,5 \\
20 min a $177^{\circ} \mathrm{C}$ & $-41,4$ & $-47,5$ & --- & 23,4 \\
500h a $25^{\circ} \mathrm{C}$ e $98 \%$ umidade relativa & $-8,6$ & $-6,6$ & $-8,3$ & $-1,9$ \\
$500 \mathrm{~h}$ a $38^{\circ} \mathrm{C}$ e $98 \%$ umidade relativa & $-44,8$ & $-47,5$ & $-33,3$ & 3,7 \\
Imersão por $500 \mathrm{~h}$ a $25^{\circ} \mathrm{C}$ em água destilada & $-19,0$ & $-16,4$ & $-13,9$ & 2,8 \\
240h a $35^{\circ} \mathrm{C}$ em névoa salina & $-34,8$ & $-39,2$ & $-38,9$ & $-0,5$ \\
$500 \mathrm{~h}$ a $35^{\circ} \mathrm{C}$ em névoa salina & $-45,9$ & $-46,8$ & $-42,2$ & $-1,5$ \\
Ciclo de exposição 1 & $-19,0$ & $-16,4$ & $-16,7$ & $-1,9$ \\
Ciclo de exposição 2 & $-10,3$ & $-13,1$ & $-5,6$ & 13,1 \\
\hline
\end{tabular}

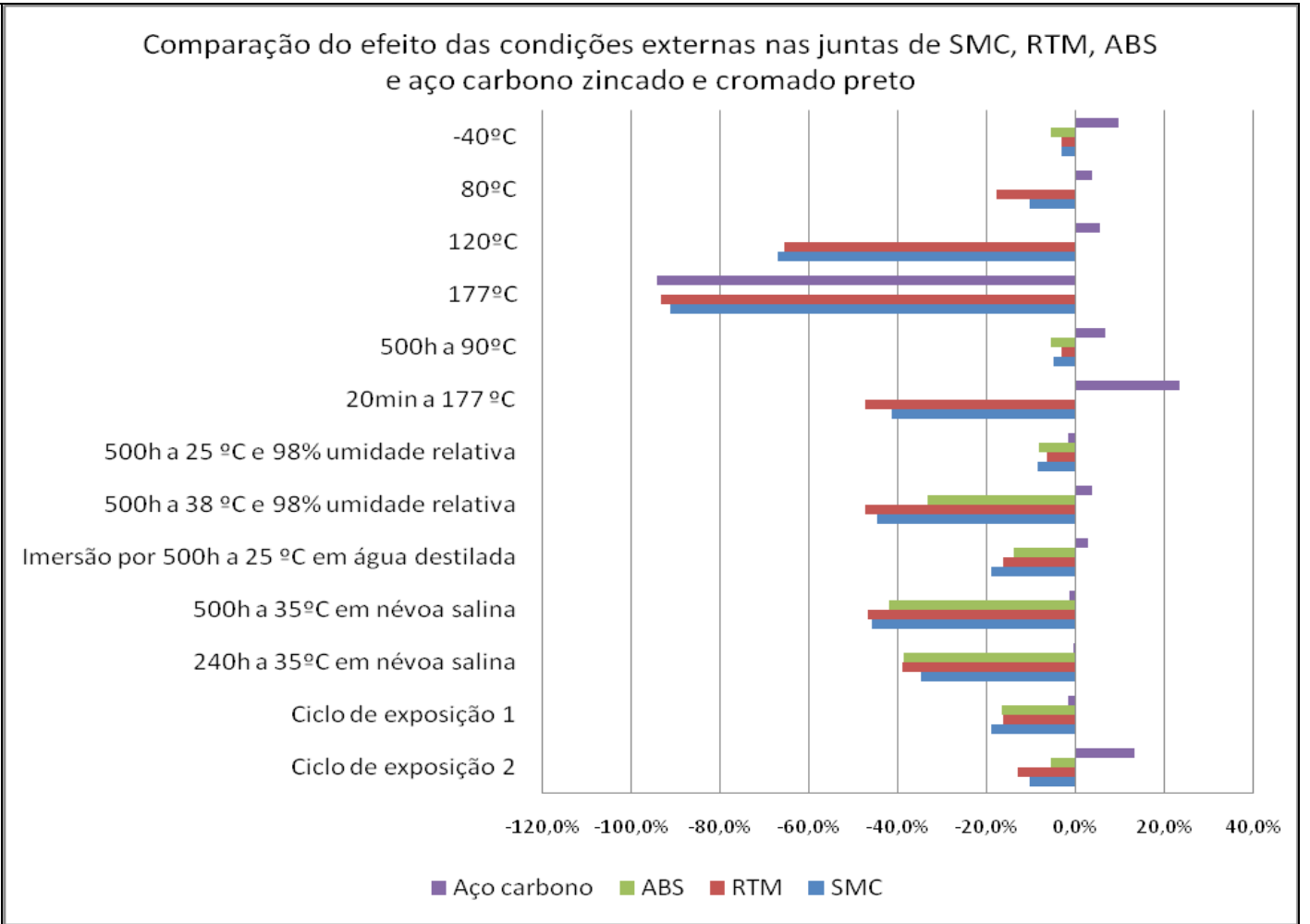

FIGURA 36 - Comparação percentual do efeito das condições externas na resistência ao cisalhamento para SMC, RTM, ABS e ACZCP. 
A imersão em água destilada reduziu a resistência ao cisalhamento das juntas de material polimérico, indicando que esta redução se deva ao efeito de hidrólise no substrato que causou ruptura no corpo de prova. No caso da junta metálica o revestimento de zincagem e cromação do aço carbono protegeu-a de oxidação. Neste caso, ocorreu um pequeno aumento da resistência ao cisalhamento com falha coesiva, mostrando que o adesivo uretânico resistiu bem à exposição direta à água destilada.

A exposição à névoa salina a $35^{\circ} \mathrm{C}$, reduziu a resistência ao cisalhamento em todas as juntas tanto após $240 \mathrm{~h}$ com após 500h. Nos corpos de prova de SMC, RTM e ABS a redução foi superior a $34 \%$ após $240 \mathrm{~h}$ e superior a $42 \%$ após $500 \mathrm{~h}$, enquanto que na junta de ACZCP, devido à pequena área de exposição, foram de apenas 0,5\% após $240 \mathrm{~h}$ e de 1,5\% após 500h.

$\mathrm{O}$ efeito combinado de temperatura, tempo, umidade e névoa salina após os ciclos 1 e 2, mostrou uma redução da resistência ao cisalhamento em todas as juntas, exceto na de metal no ciclo 2. Nas juntas expostas ao ciclo 1, a redução foi maior do que no as expostas ao ciclo 2, provavelmente devido ao efeito oxidativo da névoa salina, sendo uma das poucas condições em que a junta de ACZCP sofreu redução da resistência ao cisalhamento. Já no ciclo 2, nota-se que a junta de aço teve uma elevação da resistência ao cisalhamento, devido ao processo de pós-cura ocorrido a $90^{\circ} \mathrm{C}$.

Observaram-se reduções nas resistências ao cisalhamento de todas as juntas formadas por substratos poliméricos, enquanto que nas juntas de o substrato de aço carbono em geral o efeito foi o oposto. Portanto o adesivo uretânico resistiu muito mais aos efeitos deletérios dos condicionamentos do que os substratos de SMC, RTM e ABS, o que favorece sua aplicação nas condições ensaiadas, uma vez que a junta estará limitada à resistência dos substratos. Há que se ressaltar mais uma vez que estes condicionamentos foram propostos a partir de normas de adesivos de montadoras e tiveram o intuito de levar estas juntas a condições extremas de utilização.

Os resultados obtidos de resistência ao cisalhamento até o momento estão acima do mínimo exigido pelas normas Ford - WSBM11P27B que é de 2,8MPa e para a norma da International - TMS6900 de 4,8MPa, portanto o adesivo encontra-se por estas normas aprovado para uso em colagens de compósito automotivo. 


\subsection{Avaliação da resistência a clivagem}

Para avaliação da resistência à clivagem são necessários corpos de prova com espessura de $16 \mathrm{~mm}$ (5/8 pol), conforme descrito na norma ASTM D1062 e detalhado no item 6.4., por isso não foi possível realizar este ensaio nos mesmos substratos de SMC, RTM, ABS e ACZCP, utilizados anteriormente. No lugar deles foram confeccionados, por usinagem, os corpos de prova com a mesma matriz polimérica e reforço (poliéster e fibra de vidro) moldado por spray-up e também de aço carbono sem galvanização. Os resultados encontram-se na TAB. 19.

TABELA 19 - Avaliação da resistência a clivagem

\begin{tabular}{cccc}
\hline Substrato & $\begin{array}{c}\text { Resistência à clivagem } \\
(\mathrm{N} / \mathrm{mm} .)\end{array}$ & $\begin{array}{c}\text { Incerteza } \\
\text { Expandida }\end{array}$ & $\begin{array}{c}\text { Forma de } \\
\text { ruptura }\end{array}$ \\
\hline Laminado - spray-up & 114,5 & 2,3 & Corpo de prova \\
Aço carbono & 90,5 & 3,3 & Coesiva/Adesiva \\
\hline
\end{tabular}

No ensaio de resistência a clivagem o resultado é obtido pela divisão da força necessária para separar o corpo de prova pela sua largura e não pela área como no de cisalhamento. Isto se deve pelo fato desta força não aumentar ou diminuir em função do comprimento. Por isto o resultado é expresso em N/mm.

Para o compósito ocorreu falha do substrato por ruptura do corpo de prova o que indica que, embora este tipo de esforço seja o menos indicado para uso em juntas coladas, ainda assim o adesivo teve um desempenho satisfatório, ocorrendo primeiramente falha do substrato, conforme mostra a FIG. 37. 


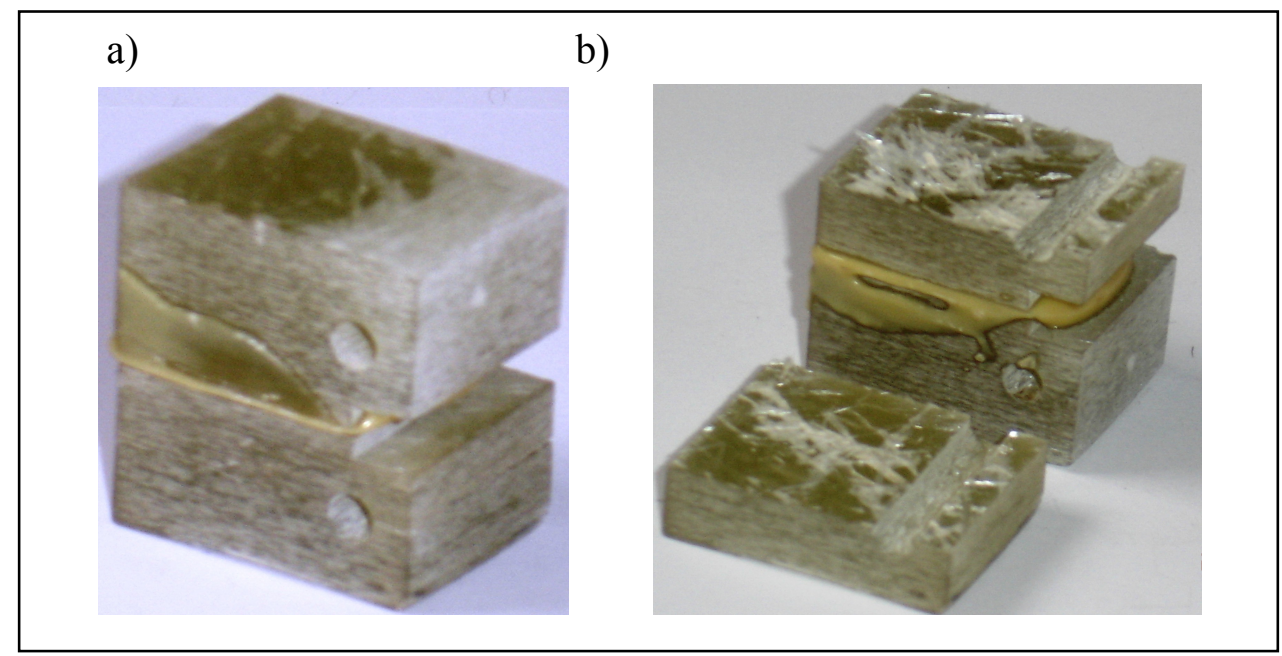

FIGURA 37 - Avaliação de Resistência a Clivagem - a) Spray-up antes da clivagem, b) Spray-up após ruptura do corpo de prova.

Nos substrato de aço carbono, mostrado na FIG.38 a resistência à clivagem foi inferior a obtida no compósito devido à menor uma interação entre o adesivo e o substrato, havendo falha coesiva e adesiva simultaneamente. Nesta situação entende-se que a força coesiva e a adesiva estão no mesmo patamar de grandeza por isso a falha adesiva e coesiva aconteceram simultaneamente.

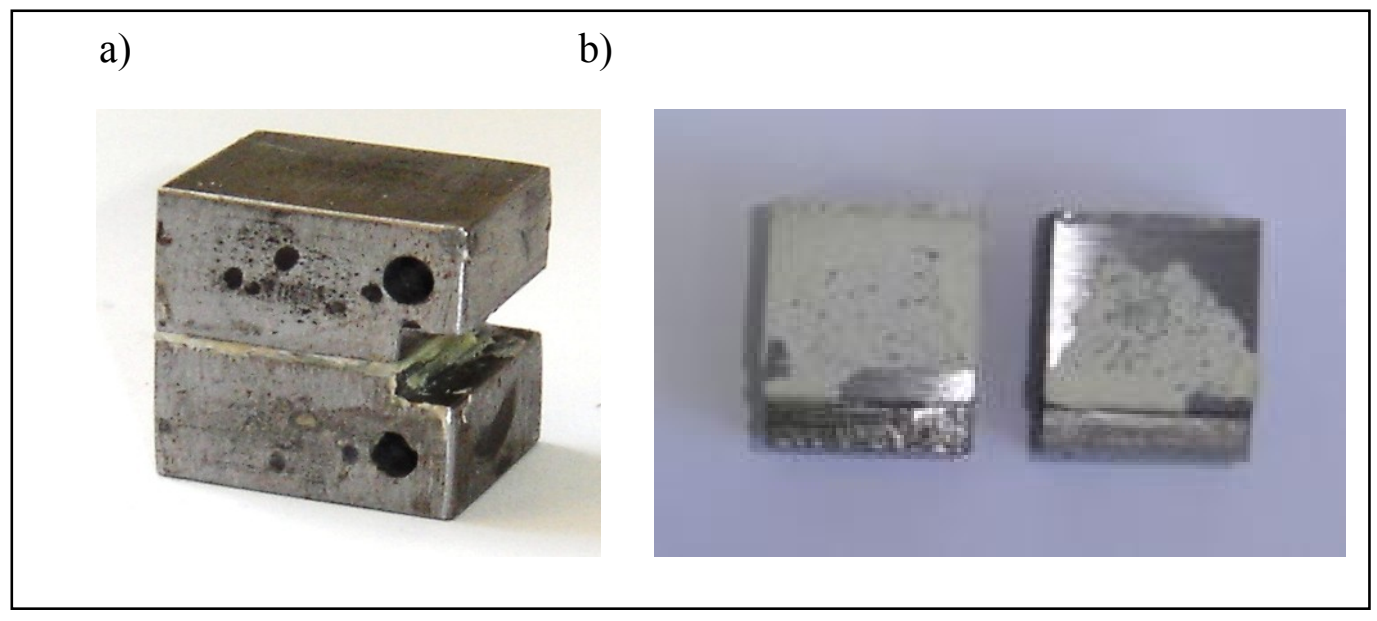

FIGURA 38 - Avaliação de Resistência a Clivagem - a) Aço carbono antes da clivagem, b) Aço carbono após ruptura do corpo de prova.

Sempre que possível deve ser evitado que uma junta seja submetida ao esforço de clivagem, pois de todos os possíveis esforços este é o que apresenta sempre a menor 
resistência mecânica, independente do adesivo utilizado. Muito embora não seja possível em muitas situações evitar por completo que uma junta sofra este esforço, um elaborado projeto de junta deve sempre procurar atenuar este tipo de esforço. Isto pode ser feito pelo uso de reforços de colagem, aumento da largura da junta e sobreposição de camadas para aumentar a rigidez. A FIG. 39 ilustra a distribuição da tensão durante o ensaio de clivagem.

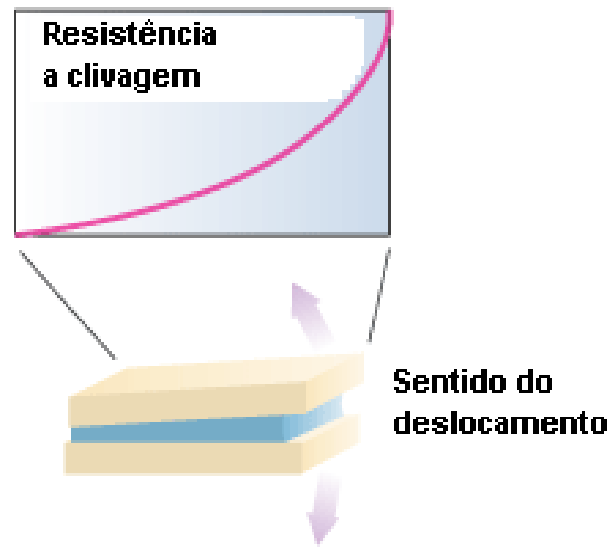

FIGURA 39 - Distribuição da tensão no ensaio de clivagem (Specialchem4adhesive, 2003)

\subsection{Tratamentos de superfície}

O procedimento tradicional de preparação de superfície dos compósitos SMC e RTM e do termoplástico ABS é o lixamento e limpeza com álcool isopropílico para remoção de desmoldantes e impurezas do substrato. Porém este procedimento gera grande quantidade de pó nas instalações industriais e têm sido estudados métodos alternativos de preparação de superfície como exposição ao plasma e uso de solvente de limpeza alternativo que dispense o lixamento.

Para o ACZCP a aderência apenas com limpeza com álcool isopropílico tem se mostrado eficiente, portanto não foram investigados métodos de preparação neste substrato.

\subsubsection{Tratamento com plasma}

O tratamento com plasma foi conduzido conforme descrito no anexo D pelo tempo de 2s de exposição ao plasma de ar comprimido, seguido de um acompanhamento da variação da energia de superfície pelo método Test Ink, para os substratos de SMC, RTM e ABS sem lixamento. Os resultados de antes e após a exposição encontram-se na TAB. 20. 
TABELA 20 - Avaliação da resistência ao cisalhamento após exposição ao plasma

\begin{tabular}{ccccccc}
\hline Substrato & $\begin{array}{c}\text { Tratamento } \\
\text { de superfície }\end{array}$ & $\begin{array}{c}\text { Energia de } \\
\text { superfície }\left(\mathrm{mN} \cdot \mathrm{m}^{-1}\right)\end{array}$ & $\begin{array}{c}\text { Resistência ao } \\
\text { cisalhamento }(\mathrm{MPa})\end{array}$ & $\begin{array}{c}\text { Incerteza } \\
\text { Expandida }\end{array}$ & $\begin{array}{c}\text { Variação } \\
(\%)\end{array}$ & $\begin{array}{c}\text { Forma de } \\
\text { ruptura }\end{array}$ \\
\hline SMC & Nenhum & 41 & 2,8 & 0,21 & $-51,7$ & Adesiva \\
SMC & Plasma & 75 & 5,9 & 0,33 & 1,7 & Delaminação \\
RTM & Nenhum & 41 & 2,1 & 0,12 & $-65,6$ & Adesiva \\
RTM & Plasma & 75 & 6,0 & 0,61 & $-1,6$ & Corpo de prova \\
ABS & Nenhum & 35 & 3,6 & 0,10 & 0,0 & Corpo de prova \\
ABS & Plasma & 73 & 3,6 & 0,10 & 0,0 & Corpo de prova \\
\hline
\end{tabular}

Os resultados obtidos demonstram primeiramente que a aderência do adesivo uretânico nos substratos compósitos de SMC e RTM sem lixamento foi ineficiente, onde se observou valores de resistência ao cisalhamento de apenas $2,8 \mathrm{MPa}$ para o $\mathrm{SMC}$ e de $2,1 \mathrm{MPa}$ para o RTM com falha adesiva, ou em termos de variação comparativa com aquele primeiro ensaio a $25^{\circ} \mathrm{C}$, as reduções foram de $51,7 \%$ e $65,5 \%$ respectivamente. Esta falha adesiva é atribuída a presença dos desmoldantes na superfície dos substratos oriundos nos moldes utilizados nos processos de moldagem destas peças. No entanto para o substrato de ABS não há variação alguma de resistência e mesmo sem nenhuma preparação de superfície a aderência foi a mesma com mesmo modo de falha por ruptura do corpo de prova, evidenciando assim que não há necessidade de lixamento ou uso de solventes. Embora por precaução nos processos industriais sempre se recomende alguma limpeza com solvente pois durante o manuseio das peças em ABS elas podem ser contaminadas por sujeiras diversas e prejudicar a adesão.

$\mathrm{O}$ tratamento com plasma mostrou ser eficiente nas colagens dos corpos de prova em SMC e RTM que apresentaram resistências ao cisalhamento de 5,9 e 6,0 MPa que são aproximadamente as mesmas resistências obtidas na condição de $25^{\circ} \mathrm{C}$. O significativo aumento da energia de superfície mostrou que houve uma remoção dos desmoldantes e modificação da superfície para o contato com o adesivo.

Por observação destes resultados o tratamento com plasma, alternativo ao lixamento, tem sido proposto para as empresas fabricantes de peças em SMC e RTM e encontra-se em estudo futuro, pois ainda os custos envolvidos no tratamento com plasma em escala industrial são elevados.

\subsubsection{Limpeza com solvente}

Uma alternativa de custo inferior ao tratamento com plasma seria o emprego de outros solventes para remoção dos desmoldantes nos substratos de SMC e RTM, uma vez que foi 
demonstrado que para os substratos de ABS e ACZCP não tem sido necessários tratamentos além de uma simples limpeza com álcool isopropílico. Foram utilizados para limpeza da superfície os solventes tricloroetileno, tolueno, acetona, álcool isopropílico, pentano e desengraxante LD 1264 fornecido pela Starquimica. Os resultados encontram-se na TAB.21.

Os resultados de limpeza com os solventes escolhidos foram semelhantes para os substratos de SMC e RTM. Os solventes utilizados na limpeza dos corpos de prova que melhoraram a resistência ao cisalhamento ao ponto de serem considerados adequados para a esta aplicação foram o tricloroetileno e o LD1264. Nestes casos as juntas apresentaram resultados de resistência ao cisalhamento muito próximo daqueles obtidos na condição inicial de $25^{\circ} \mathrm{C}$ com falha por delaminação e por ruptura do corpo de prova, que comprovam a eficiência do método.

A limpeza com os solventes, tolueno, isopropanol e pentano mostraram algum incremento na resistência ao cisalhamento porém ainda com falha adesiva que é sempre indesejável em colagens estruturais. A limpeza com acetona mostrou um incremento um pouco mais elevado do que tolueno, isopropanol e pentano, com falha adesiva e coesiva, mas ainda não se pode considerar como satisfatório.

TABELA 21 - Avaliação da resistência ao cisalhamento após limpeza com solventes.

\begin{tabular}{|c|c|c|c|c|c|}
\hline Substrato & $\begin{array}{l}\text { Solvente } \\
\text { utilizado }\end{array}$ & $\begin{array}{c}\text { Resistência ao } \\
\text { cisalhamento }(\mathrm{MPa})\end{array}$ & $\begin{array}{r}\text { Incerteza } \\
\text { Expandida }\end{array}$ & $\begin{array}{c}\text { Variação } \\
(\%)\end{array}$ & $\begin{array}{c}\text { Forma de } \\
\text { ruptura }\end{array}$ \\
\hline SMC & Nenhum & 2,8 & 0,22 & $-51,7$ & Adesiva \\
\hline $\mathrm{SMC}$ & Tricloroetileno & 5,9 & 0,42 & 1,7 & Delaminação \\
\hline $\mathrm{SMC}$ & Tolueno & 3,5 & 0,32 & $-39,7$ & Adesiva \\
\hline $\mathrm{SMC}$ & Acetona & 4,4 & 0,30 & $-24,1$ & Adesiva/Coesiva \\
\hline $\mathrm{SMC}$ & Isopropanol & 3,3 & 0,27 & $-43,1$ & Adesiva \\
\hline $\mathrm{SMC}$ & Pentano & 2,9 & 0,22 & $-50,0$ & Adesiva \\
\hline $\mathrm{SMC}$ & LD 1264 & 6,0 & 0,54 & 3,4 & Delaminação \\
\hline RTM & Nenhum & 2,1 & 0,14 & $-65,6$ & Adesiva \\
\hline RTM & Tricloroetileno & 6,0 & 0,44 & $-1,6$ & Corpo de prova \\
\hline RTM & Tolueno & 3,2 & 0,20 & $-47,5$ & Adesiva \\
\hline RTM & Acetona & 5,0 & 0,39 & $-18,0$ & Adesiva/Coesiva \\
\hline RTM & Isopropanol & 3,0 & 0,11 & $-50,8$ & Adesiva \\
\hline RTM & Pentano & 2,8 & 0,10 & $-49,2$ & Adesiva \\
\hline RTM & LD 1264 & 5,9 & 0,23 & $-3,3$ & Corpo de prova \\
\hline
\end{tabular}


O presente trabalho de avaliação de métodos alternativos de tratamento de superfície propõe o uso do plasma ou limpeza com os solventes tricloroetileno ou LD1264 em processos industriais, pois os resultados iniciais indicam que eles foram capazes de remover os contaminantes da superfície dos substratos compósitos e desta forma a interação do adesivosubstrato foi facilitada.

Atualmente a limpeza com o desengraxante LD1264 tem sido empregada como alternativa ao lixamento nos processos onde colagem de peças em RTM e SMC com adesivo Masterpur Estrutural 300, fruto dos resultados do presente estudo. Para que este método fosse empregado foi necessária a realização dos mesmos testes de condicionamentos descritos no item 7.4 e estão apresentados nas TABELAS 22 e 23.

TABELA 22 - Resultados comparativos de resistência ao cisalhamento em corpos de prova de SMC lixados ou limpos com desengraxante LD1263.

\begin{tabular}{|c|c|c|c|c|}
\hline Condicionamento & $\begin{array}{c}\text { Resistência ao } \\
\text { cisalhamento (MPa) }\end{array}$ & $\begin{array}{l}\text { Incerteza } \\
\text { expandida }\end{array}$ & $\begin{array}{c}\text { Preparação da } \\
\text { superfície }\end{array}$ & Forma de ruptura \\
\hline \multirow[t]{2}{*}{$-40^{\circ} \mathrm{C}$} & 5,6 & 0,40 & Lixamento & Delaminação \\
\hline & 5,6 & 0,35 & LD1264 & Delaminação \\
\hline \multirow{2}{*}{$25^{\circ} \mathrm{C}$} & 5,8 & 0,40 & Lixamento & Delaminação \\
\hline & 6,0 & 0,54 & LD1264 & Delaminação \\
\hline \multirow[t]{2}{*}{$80^{\circ} \mathrm{C}$} & 5,2 & 0,32 & Lixamento & Delaminação \\
\hline & 5,2 & 0,30 & LD1264 & Delaminação \\
\hline \multirow[t]{2}{*}{$120^{\circ} \mathrm{C}$} & 1,9 & 0,10 & Lixamento & Delaminação \\
\hline & 1,8 & 0,10 & LD1264 & Delaminação \\
\hline \multirow[t]{2}{*}{$177^{\circ} \mathrm{C}$} & 0,5 & 0,10 & Lixamento & Coesiva \\
\hline & 0,4 & 0,10 & LD1264 & Coesiva \\
\hline \multirow[t]{2}{*}{$500 \mathrm{~h} \mathrm{a} \quad 90^{\circ} \mathrm{C}$} & 5,5 & 0,43 & Lixamento & Corpo de prova \\
\hline & 5,6 & 0,42 & LD1264 & Corpo de prova \\
\hline \multirow{2}{*}{$20 \min$ a $177^{\circ} \mathrm{C}$} & 3,4 & 0,77 & Lixamento & Delaminação \\
\hline & 3,7 & 0,42 & LD1264 & Delaminação \\
\hline \multirow[t]{2}{*}{$500 \mathrm{~h}$ a $25^{\circ} \mathrm{C}$ e $98 \%$ de umidade relativa. } & 5,3 & 0,25 & Lixamento & Corpo de prova \\
\hline & 5,7 & 0,20 & LD1264 & Corpo de prova \\
\hline \multirow[t]{2}{*}{$500 \mathrm{~h}$ a $38^{\circ} \mathrm{C}$ e $98 \%$ de umidade relativa. } & 3,2 & 0,41 & Lixamento & Delaminação \\
\hline & 3,2 & 0,41 & LD1264 & Delaminação \\
\hline 500h de imersão em água destilada a & 4,7 & 0,32 & Lixamento & Corpo de prova \\
\hline $25^{\circ} \mathrm{C}$ & 4,8 & 0,32 & LD1264 & Corpo de prova \\
\hline \multirow[t]{2}{*}{$240 \mathrm{~h}$ em névoa salina } & 3,8 & 0,46 & Lixamento & Delaminação \\
\hline & 4,0 & 0,36 & LD1264 & Delaminação \\
\hline \multirow[t]{2}{*}{ 500h em névoa salina } & 3,1 & 0,39 & Lixamento & Delaminação \\
\hline & 3,5 & 0,33 & LD1264 & Delaminação \\
\hline Ciclo 1 - 42 vezes, $16 \mathrm{~h} / 25^{\circ} \mathrm{C} / 98 \% \mathrm{UR}$ & 4,7 & 0,40 & Lixamento & Delaminação \\
\hline $2 \mathrm{~h} /-30^{\circ} \mathrm{C}, 2 \mathrm{~h} / 25^{\circ} \mathrm{C}, 2 \mathrm{~h} /$ névoa salina, & 5,1 & 0,45 & LD1264 & Delaminação \\
\hline $2 \mathrm{~h} / 70^{\circ} \mathrm{C}$ & & & & \\
\hline Ciclo 1 - 10 vezes, $16 \mathrm{~h} / 38^{\circ} \mathrm{C} 98 \% \mathrm{UR}$, & 5,2 & 0,45 & Lixamento & Delaminação \\
\hline $4 \mathrm{~h} /-40^{\circ} \mathrm{C}, 4 \mathrm{~h} / 90^{\circ} \mathrm{C}$ & 5,3 & 0,35 & LD1264 & Delaminação \\
\hline
\end{tabular}


Os resultados de resistência ao cisalhamento obtidos em juntas de SMC e RTM lixadas e com limpeza com solvente são muito próximos e as vezes até iguais. Considerando ainda a incerteza expandida das medições não é possível indicar nenhuma diferença significativa entre os resultados após lixamento e limpeza com solvente. Tal comparação leva a propor que a limpeza com solvente foi eficaz na remover o desmoldante da superfície dos substratos de SMC e RTM e preparar uma superfície livre de contaminantes que poderiam impedir o contato do adesivo com o substrato.

TABELA 23 - Resultados comparativos de resistência ao cisalhamento em corpos de prova de RTM lixados ou limpos com desengraxante LD1263.

\begin{tabular}{|c|c|c|c|c|}
\hline Condicionamento & $\begin{array}{c}\text { Resistência ao } \\
\text { cisalhamento }(\mathrm{MPa})\end{array}$ & $\begin{array}{l}\text { Incerteza } \\
\text { expandida }\end{array}$ & $\begin{array}{c}\text { Preparação da } \\
\text { superfície }\end{array}$ & Forma de ruptura \\
\hline \multirow{2}{*}{$-40^{\circ} \mathrm{C}$} & 5,9 & 0,26 & Lixamento & Corpo de prova \\
\hline & 6,0 & 0,22 & LD1264 & Corpo de prova \\
\hline \multirow{2}{*}{$25^{\circ} \mathrm{C}$} & 6,1 & 0,31 & Lixamento & Corpo de prova \\
\hline & 5,9 & 0,23 & LD1264 & Corpo de prova \\
\hline \multirow{2}{*}{$80^{\circ} \mathrm{C}$} & 5,0 & 0,22 & Lixamento & Corpo de prova \\
\hline & 5,2 & 0,21 & LD1264 & Corpo de prova \\
\hline \multirow[t]{2}{*}{$120^{\circ} \mathrm{C}$} & 2,1 & 0,12 & Lixamento & Corpo de prova \\
\hline & 2,5 & 0,13 & LD1264 & Corpo de prova \\
\hline \multirow[t]{2}{*}{$177^{\circ} \mathrm{C}$} & 0,4 & 0,10 & Lixamento & Coesiva \\
\hline & 0,3 & 0,10 & LD1264 & Coesiva \\
\hline \multirow[t]{2}{*}{$500 \mathrm{~h} \mathrm{a} \quad 90^{\circ} \mathrm{C}$} & 5,9 & 0,17 & Lixamento & Corpo de prova \\
\hline & 5,8 & 0,15 & LD1264 & Corpo de prova \\
\hline \multirow[t]{2}{*}{$20 \min$ a $177^{\circ} \mathrm{C}$} & 3,2 & 0,56 & Lixamento & Delaminação \\
\hline & 3,3 & 0,44 & LD1264 & Delaminação \\
\hline \multirow[t]{2}{*}{$500 \mathrm{~h}$ a $25^{\circ} \mathrm{C}$ e $98 \%$ de umidade relativa. } & 5,7 & 0,23 & Lixamento & Corpo de prova \\
\hline & 5,5 & 0,21 & LD1264 & Corpo de prova \\
\hline \multirow[t]{2}{*}{$500 \mathrm{~h}$ a $38^{\circ} \mathrm{C}$ e $98 \%$ de umidade relativa. } & 3,2 & 0,29 & Lixamento & Delaminação \\
\hline & 3,1 & 028 & LD1264 & Delaminação \\
\hline 500h de imersão em água destilada a & 5,1 & 0,35 & Lixamento & Corpo de prova \\
\hline $25^{\circ} \mathrm{C}$ & 5,5 & 0,38 & LD1264 & Corpo de prova \\
\hline \multirow[t]{2}{*}{$240 \mathrm{~h}$ em névoa salina } & 3,7 & 0,60 & Lixamento & Delaminação \\
\hline & 4,0 & 0,31 & LD1264 & Delaminação \\
\hline \multirow[t]{2}{*}{ 500h em névoa salina } & 3,2 & 0,33 & Lixamento & Delaminação \\
\hline & 3,1 & 0,31 & LD1264 & Delaminação \\
\hline Ciclo 1 - 42 vezes, $16 \mathrm{~h} / 25^{\circ} \mathrm{C} / 98 \% \mathrm{UR}$ & 5,1 & 0,33 & Lixamento & Corpo de prova \\
\hline $2 \mathrm{~h} /-30^{\circ} \mathrm{C}, 2 \mathrm{~h} / 25^{\circ} \mathrm{C}, 2 \mathrm{~h} /$ névoa salina, & 5,0 & 0,41 & LD1264 & Corpo de prova \\
\hline $2 \mathrm{~h} / 70{ }^{\circ} \mathrm{C}$ & & & & \\
\hline Ciclo 1 - 10 vezes, $16 \mathrm{~h} / 38^{\circ} \mathrm{C} 98 \% \mathrm{UR}$ & 5,3 & 0,30 & Lixamento & Delaminação \\
\hline $4 \mathrm{~h} /-40^{\circ} \mathrm{C}, 4 \mathrm{~h} / 90^{\circ} \mathrm{C}$ & 5,1 & 0,39 & LD1264 & Delaminação \\
\hline
\end{tabular}

\subsection{Avaliação das propriedades térmicas}

As propriedades térmicas do adesivo e dos substratos foram avaliadas por termogravimetria, análise térmica diferencial e calorimetria diferencial exploratória. 


\subsubsection{Termogravimetria (TG)}

A termogravimetria foi utilizada para comparar a estabilidade térmica entre o adesivo uretânico, seus componentes e os substratos compósitos de SMC e RTM e o termoplástico ABS. As condições de ensaios utilizadas foram taxa de aquecimento de $10^{\circ} \mathrm{C} \cdot \mathrm{min}^{-1}$ até $900^{\circ} \mathrm{C}$, fluxo de ar comprimido de $50 \mathrm{~mL} \cdot \mathrm{min}^{-1}$, quantidade de amostra entre 5 a $15 \mathrm{mg}$.

\subsubsection{Termogravimetria do adesivo uretânico}

O adesivo uretânico foi analisado após $24 \mathrm{~h}$ de cura, como também os componentes a base de poliol e isocianato, respectivamente, A e B. A FIG. 40 ilustra o termograma do componente poliol.

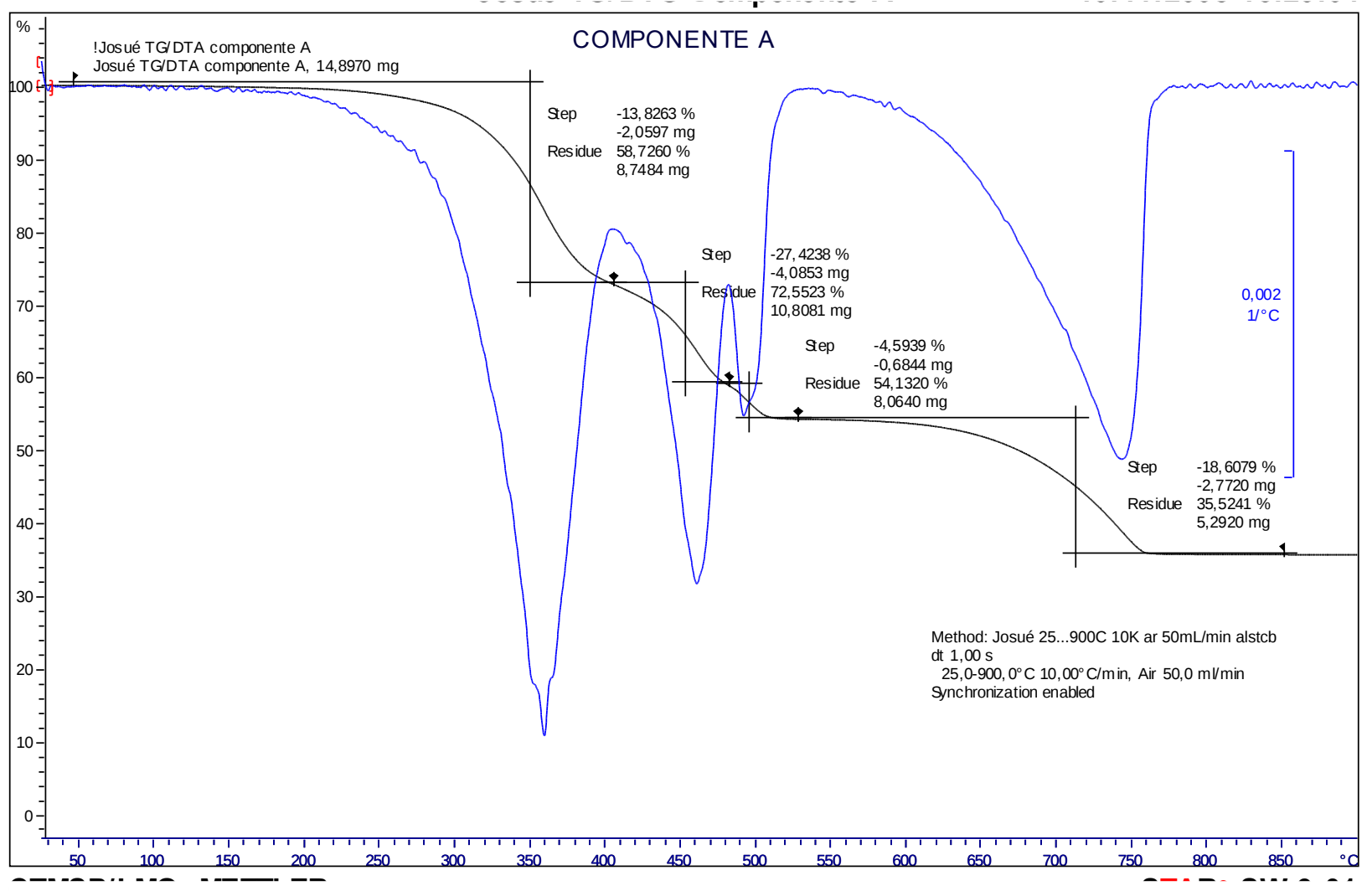

FIGURA 40 - Curva termogravimétrica do componente poliol do adesivo uretânico 
Nesta figura observam-se quatro eventos de perda de massa o primeiro deles inicia-se a temperatura de $200^{\circ} \mathrm{C}$ e termina a $380^{\circ} \mathrm{C}$, com perda máxima a $350^{\circ} \mathrm{C}$. Neste evento há uma perda de massa de $27,4 \%$. O segundo evento, com perda massa de $12,6 \%$, ocorre entre $430^{\circ} \mathrm{C}$ e $480^{\circ} \mathrm{C}$, com perda máxima a $460^{\circ} \mathrm{C}$. O terceiro evento ocorre entre $480^{\circ} \mathrm{C}$ e $500^{\circ} \mathrm{C}$ com perda de massa de 5,9\%. O último evento inicia-se em $550^{\circ} \mathrm{C}$ e termina em $750^{\circ} \mathrm{C}$, com perda máxima a $740^{\circ} \mathrm{C}$. A perda de massa neste evento foi de $18,6 \%$. Somando as perdas de massa obtém-se um total de $64,5 \%$, consequentemente tem-se um resíduo de $35,5 \%$.

Sabendo-se que o componente A é composto por um poliol líquido, aditivos e cargas minerais, entre elas principalmente o carbonato de cálcio, é possível identificar os eventos de perda de massa.

Os três primeiros eventos correspondem a evaporação do poliol, que é um composto orgânico. Alguns aditivos que são dosados em percentual muito pequeno, geralmente 1\% no máximo, também sofreram evaporação ou degradação, enquanto que o último evento trata-se da decomposição do carbonato de cálcio que é dada pela reação ilustrada na FIG.41. Conforme dados da literatura (Almeida, 2007) esta reação ocorre entre $600{ }^{\circ} \mathrm{C}$ a $700{ }^{\circ} \mathrm{C}$.

$$
\mathrm{CaCO}_{3(\mathrm{~s})} \stackrel{\Delta}{\mathrm{CaO}_{(\mathrm{s})}}+\mathrm{CO}_{2(\mathrm{~g})}
$$

FIGURA 41 - Reação de decomposição do carbonato de cálcio

Como em geral os aditivos representam uma segunda fração de massa do adesivo pode-se propor que o componente A seja composto por $45,8 \%$ de poliol e aditivos e $54,2 \%$ de cargas minerais. Por uso de cálculos estequiométricos pode-se calcular com precisão o teor de carbonato de cálcio presente no componente A. Sabe-se que 100 g.mol ${ }^{-1}$ de $\mathrm{CaCO}_{3}$, geram 56 g.mol ${ }^{-1}$ de $\mathrm{CaO}$ e 44 g.mol ${ }^{-1}$ de $\mathrm{CO}_{2}$. Se a liberação de $\mathrm{CO}_{2}$ no último evento resultou na perda de $2,772 \mathrm{mg}$, tem-se então que o $\mathrm{CaCO}_{3}$ corresponde a 42,2\% da composição percentual do componente A, sendo os $12 \%$ de outros resíduos minerais.

O termograma do componente B está ilustrado na FIG.42 e mostra os três eventos de perda de massa. $\mathrm{O}$ primeiro deles inicia-se a $150^{\circ} \mathrm{C}$ e termina em $320^{\circ} \mathrm{C}$, com perda máxima em $280^{\circ} \mathrm{C}$. A perda de massa neste evento é de $44 \%$. O segundo evento inicia-se a $530^{\circ} \mathrm{C}$ e termina em $610^{\circ} \mathrm{C}$, nele há uma perda massa de $10 \%$. O último evento inicia-se a $620^{\circ} \mathrm{C}$ e termina em $740^{\circ} \mathrm{C}$, com perda máxima a $660^{\circ} \mathrm{C}$, neste último evento a perda de massa foi de $40 \%$. O resíduo foi de aproximadamente $6 \%$. 


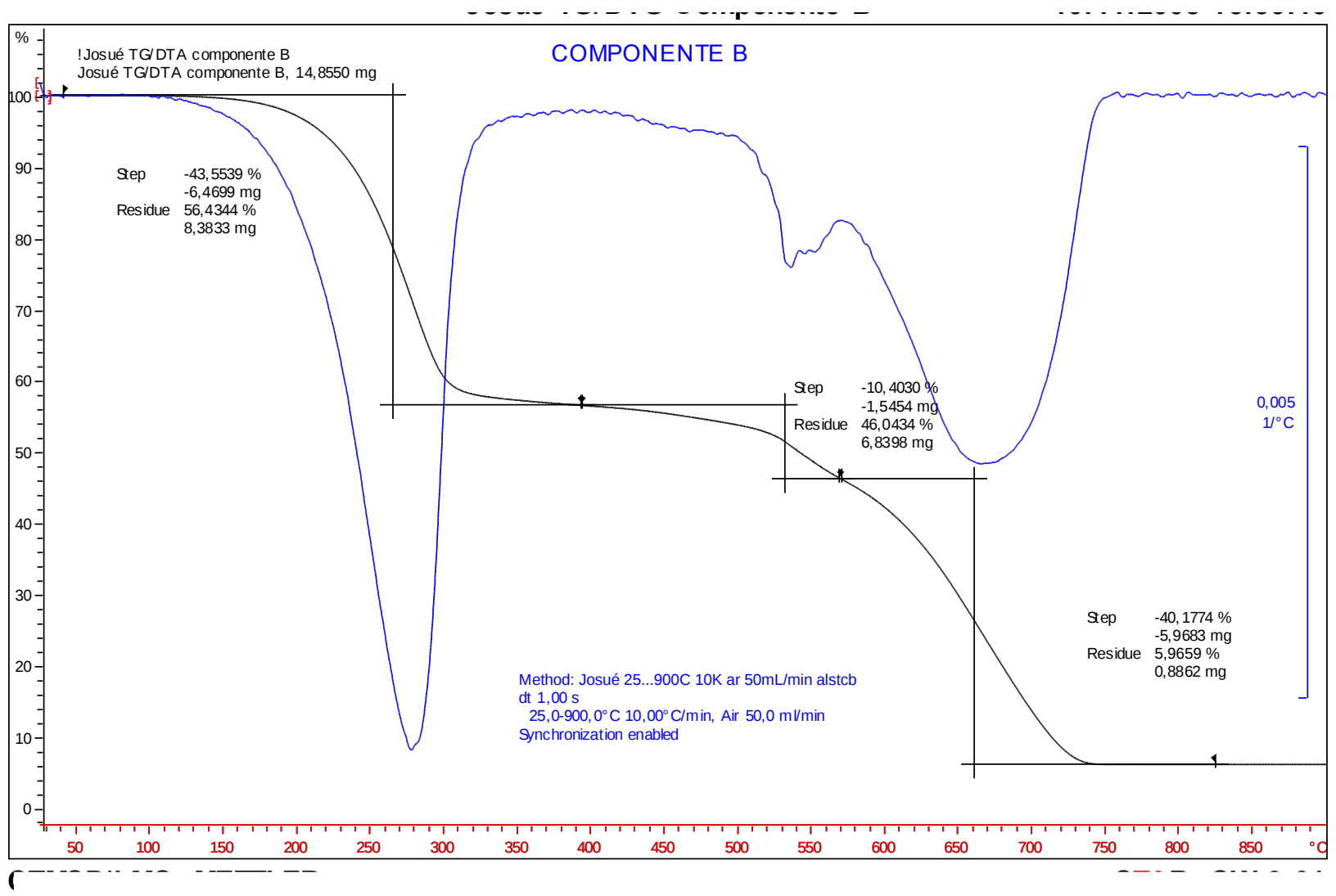

FIGURA 42 - Curva termogravimétrica do componente isocianato do adesivo uretânico.

Sob aquecimento, os isocianatos do tipo MDI do qual o componente B é composto, podem reagir entre si formando dímeros, trímeros, polímeros, carbodiimida e uretanoiminas. (VILAR, 2002) de maior massa molecular e consequentemente maior ponto de evaporação. Portanto após o início do aquecimento, uma parte do isocianato sofreu decomposição e foi liberada no primeiro evento, enquanto a outra parte se reagiu entre si formando provavelmente um polímero de massa molecular maior e que se decompôs no segundo e terceiro eventos em uma temperatura superior. Pode-se inferir que o resíduo formado trata-se de produtos de decomposição dos aditivos adicionados ao isocianato.

Por último apresenta-se o termograma do adesivo uretânico formado pela reação dos componentes A e B, conforme ilustração da FIG. 43. 


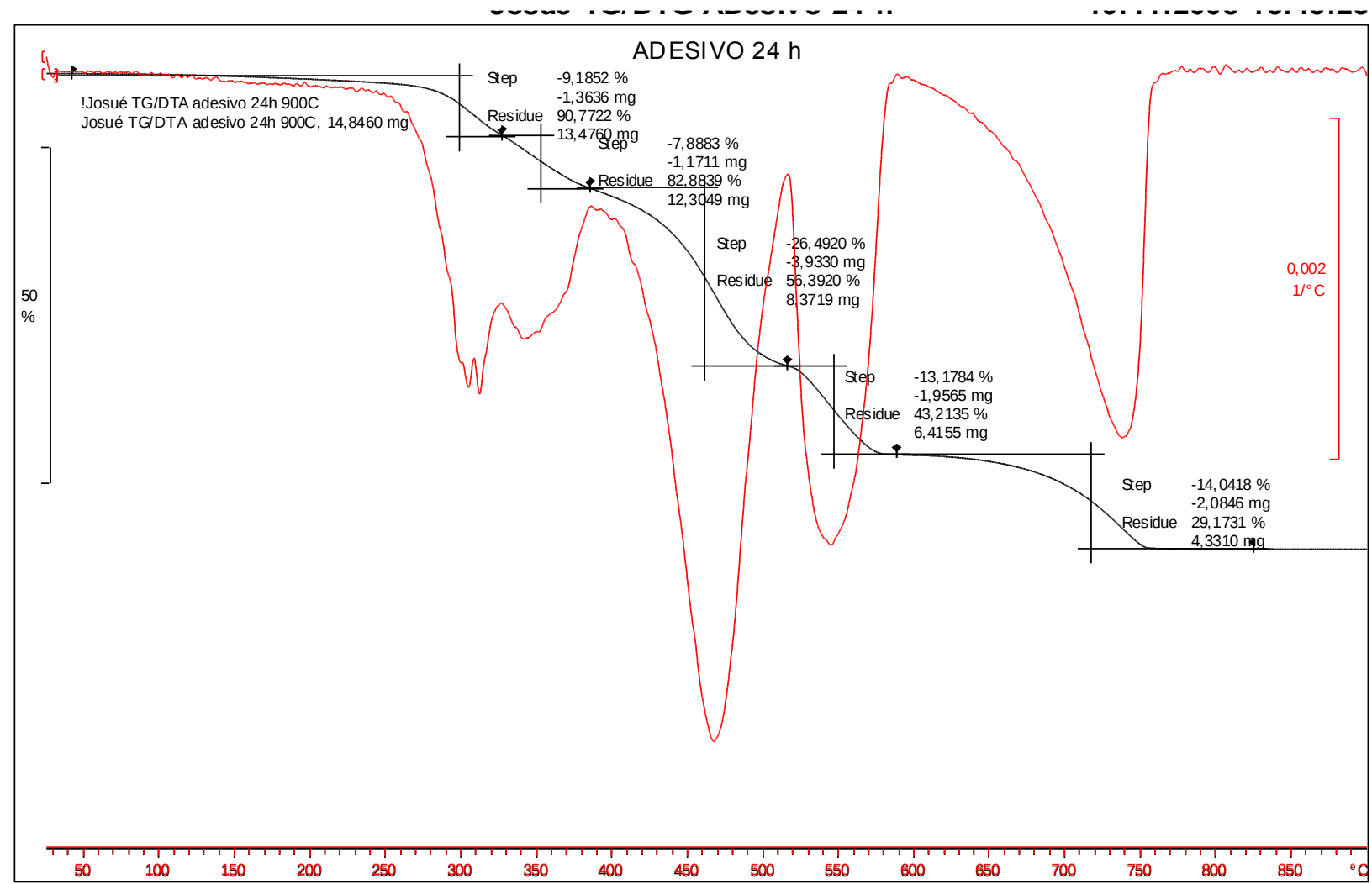

II

"

FIGURA 43 - Curva termogravimétrica do adesivo uretânico.

Observam-se cinco eventos de perda de massa. O primeiro deles ocorre entre 120 e $350^{\circ} \mathrm{C}$ com perda de $9,2 \%$, o segundo evento ocorre entre $330^{\circ} \mathrm{C}$ e $390^{\circ} \mathrm{C}$ com perda de $7,9 \%$, o terceiro evento ocorre entre $420^{\circ} \mathrm{C}$ e $500^{\circ} \mathrm{C}$ com perda de $26,5 \%$, o quarto evento ocorre entre $520^{\circ} \mathrm{C}$ e $560^{\circ} \mathrm{C}$ com perda de $13,2 \%$ e o quinto evento ocorre entre $600^{\circ} \mathrm{C}$ e $760^{\circ} \mathrm{C} \mathrm{com}$ perda de $14 \%$.

A interpretação de todos os eventos seria muito complexa, uma vez que ocorre uma reação química entre o poliol e o isocianato formando o poliuretano. Porém algumas informações importantes podem ser apontadas. A temperatura que o primeiro evento se inicia é de aproximadamente $120^{\circ} \mathrm{C}$, que mostra uma condição de uso importante, ou seja, o adesivo não deve ser exposto acima desta temperatura.

Sabendo-se que este poliuretano é um termofixo, os eventos subsequentes estão relacionados às degradações térmicas das cadeias poliméricas. Apenas podem-se comparar com clareza o último evento de degradação do adesivo com o do componente A e atribuir a decomposição do carbonato de cálcio, tanto pelo percentual de perda relativo quanto pelo desenho da curva TG. 
De forma análoga ao estudo feito da decomposição do carbonato de cálcio no componente $\mathrm{A}$, a análise pode ser feita no adesivo. No último evento houve liberação de 2,0846mg de $\mathrm{CO}_{2}$, portanto tem-se um teor de $\mathrm{CaCO}_{3}$ de $32 \%$. De fato, este resultado está bem próximo daquele esperado teoricamente. Uma vez que o adesivo é composto por 100 partes em peso de componente A e 25 partes de componente $\mathrm{B}$, partindo do observado no ensaio do componente $\mathrm{A}$ onde se obteve $42,2 \%$ de $\mathrm{CaCO}_{3}$, teríamos na mistura $33,7 \%$.

Comparando os resíduos formados no componente A de 35,5\% e no componente B de $5,9 \%$ e sabendo que a proporção da mistura é de 100:25 em peso é possível esperar um resíduo de $29,6 \%$ e foi obtido um resíduo de $29,2 \%$.

Sabendo-se previamente que o adesivo uretânico sofre reações de pós cura em função do tempo, a mistura e reação inicial, avaliou-se também o comportamento térmico do adesivo uretânico após 24h, 4 e 30 dias, a FIG.44 contém o termograma deste ensaio. Podem-se observar os mesmos eventos de decomposição térmica em todos os ensaios sem alteração da temperatura em que ocorrem. O percentual de resíduo nos três ensaios foi em média de 29,1\%.

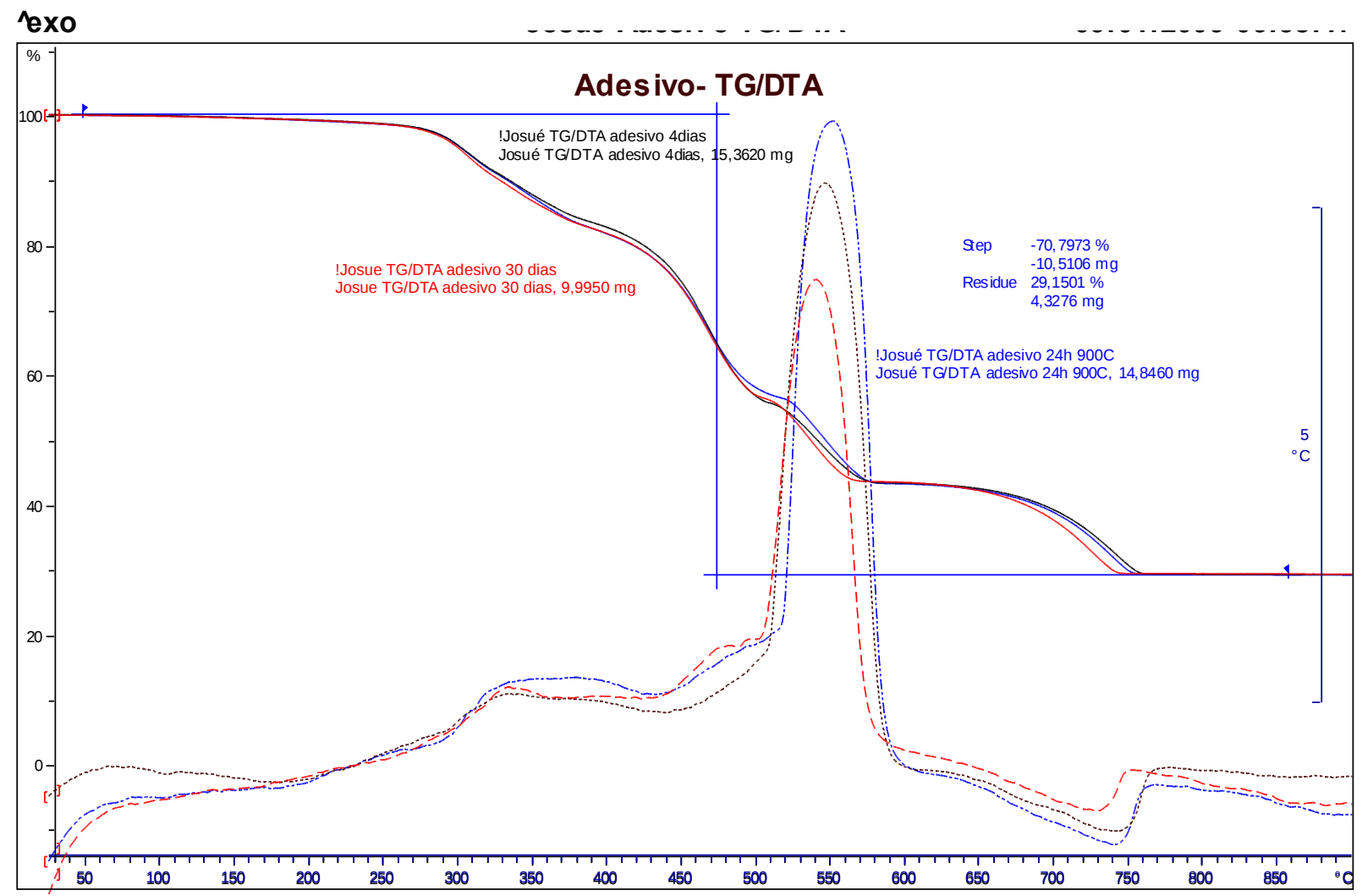

FIGURA 44 - Curva termogravimétrica do adesivo uretânico curado após 24h, 4 e 30 dias. 


\subsubsection{Termogravimetria dos substratos}

A termogravimetria foi utilizada para comparar a estabilidade térmica entre o adesivo uretânico e os substratos compósitos de SMC e RTM e o termoplástico ABS. As condições de ensaios foram taxa de aquecimento de $10{ }^{\circ} \mathrm{C} \cdot \mathrm{min}^{-1}$ até $900^{\circ} \mathrm{C}$, fluxo de ar comprimido de 50 mL.min ${ }^{-1}$, quantidade de amostra entre 5 a $15 \mathrm{mg}$. Na FIG.45 está apresentado o termograma dos substratos poliméricos SMC, RTM e ABS.

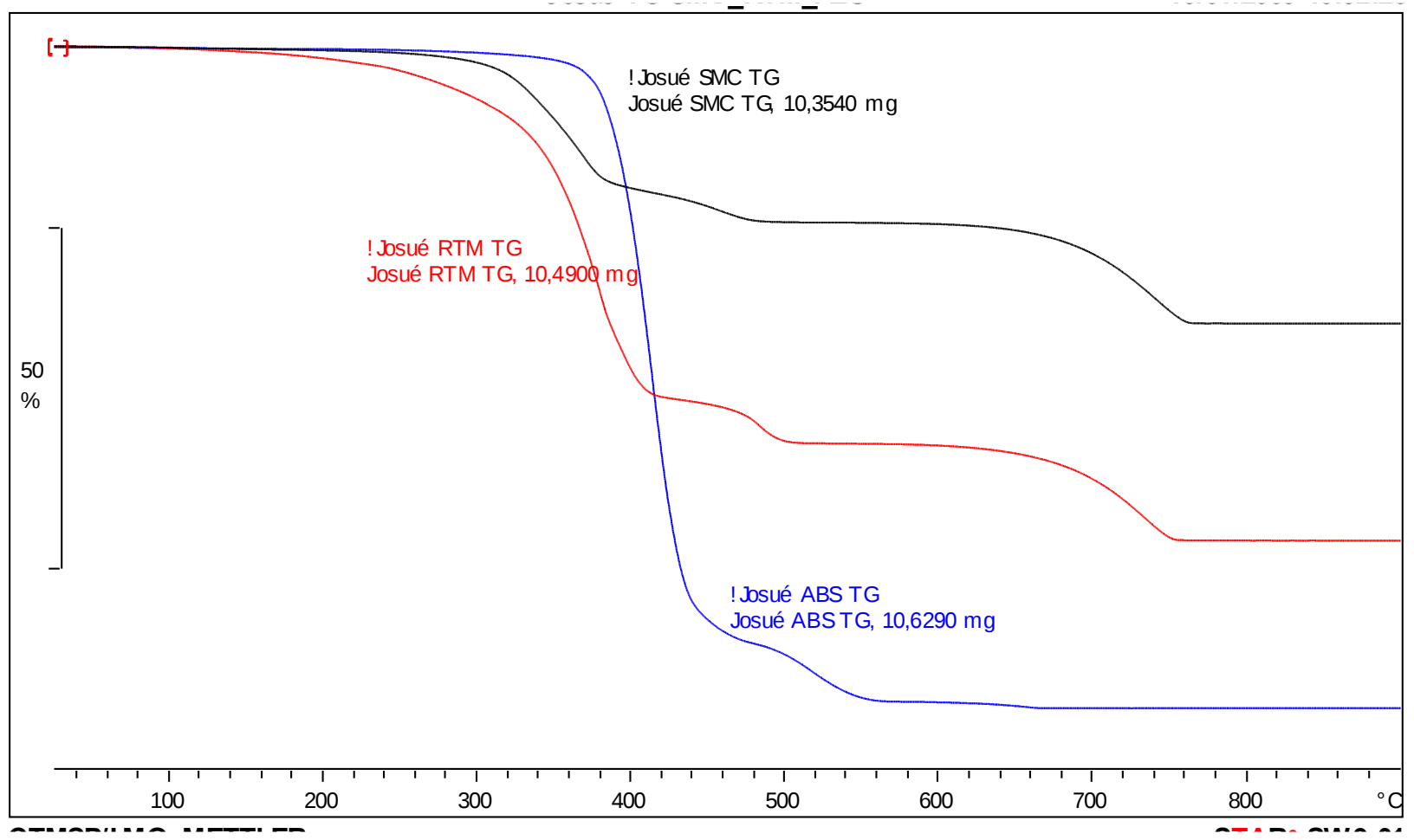

FIGURA 45 - Curva termogravimétrica dos substratos poliméricos de SMC, RTM e ABS.

De acordo com o termograma da FIGURA 43 os substratos compósitos SMC e RTM apresentaram curvas semelhantes de decomposição. Dois eventos a $200^{\circ} \mathrm{C}$ e $400^{\circ} \mathrm{C}$ para o $\mathrm{RTM}$ e a $300^{\circ} \mathrm{C}$ e $400^{\circ} \mathrm{C}$ para o SMC pode ser atribuídos a decomposição da matriz polimérica. Eventos a $700^{\circ} \mathrm{C}$ podem ser atribuídos como decomposição de carbonato de cálcio, que se encontra presente nestes compósitos.

Em relação os três substratos poliméricos avaliados o ABS é o que apresenta maior resistência de decomposição a temperatura. Pode-se observar que a partir de aproximadamente 
$380^{\circ} \mathrm{C}$ inicia-se um processo de decomposição e outro evento a $500^{\circ} \mathrm{C}$, atribuídos como a decomposição do polímero.

Na FIG.46 é possível observar com mais detalhes o termograma do compósito de SMC. O primeiro evento houve perda de $21,5 \%$ da massa, no segundo apenas 4,3\% e no último mais $14,8 \%$, restando como resíduo $59,4 \%$ da massa inicial. Considerando que o resíduo seja composto por vidro e óxido de cálcio, proveniente da decomposição do carbonato de cálcio, pode-se calcular o teor de vidro e carbonato de cálcio no compósito. Novamente utilizando a equação de decomposição do $\mathrm{CaCO}_{3}$, sabe-se por estequiometria de reação química que 100 g.mol ${ }^{-1}$ de $\mathrm{CaCO}_{3}$, geram 56 g.mol ${ }^{-1}$ de $\mathrm{CaO}$ e 44 g.mol ${ }^{-1}$ de $\mathrm{CO}_{2}$. Sabendo-se que o terceiro evento de decomposição é devido à liberação do $\mathrm{CO}_{2}$, então se pode calcular o teor de $\mathrm{CaCO}_{3}$ no compósito. A composição percentual para o compósito de SMC foi de $25,8 \%$ de matriz polimérica, $33,6 \%$ de carga mineral como carbonato de cálcio e 40,6\% de vidro.

Josué SMC TG_DTG

16.01.2009 15:30:01

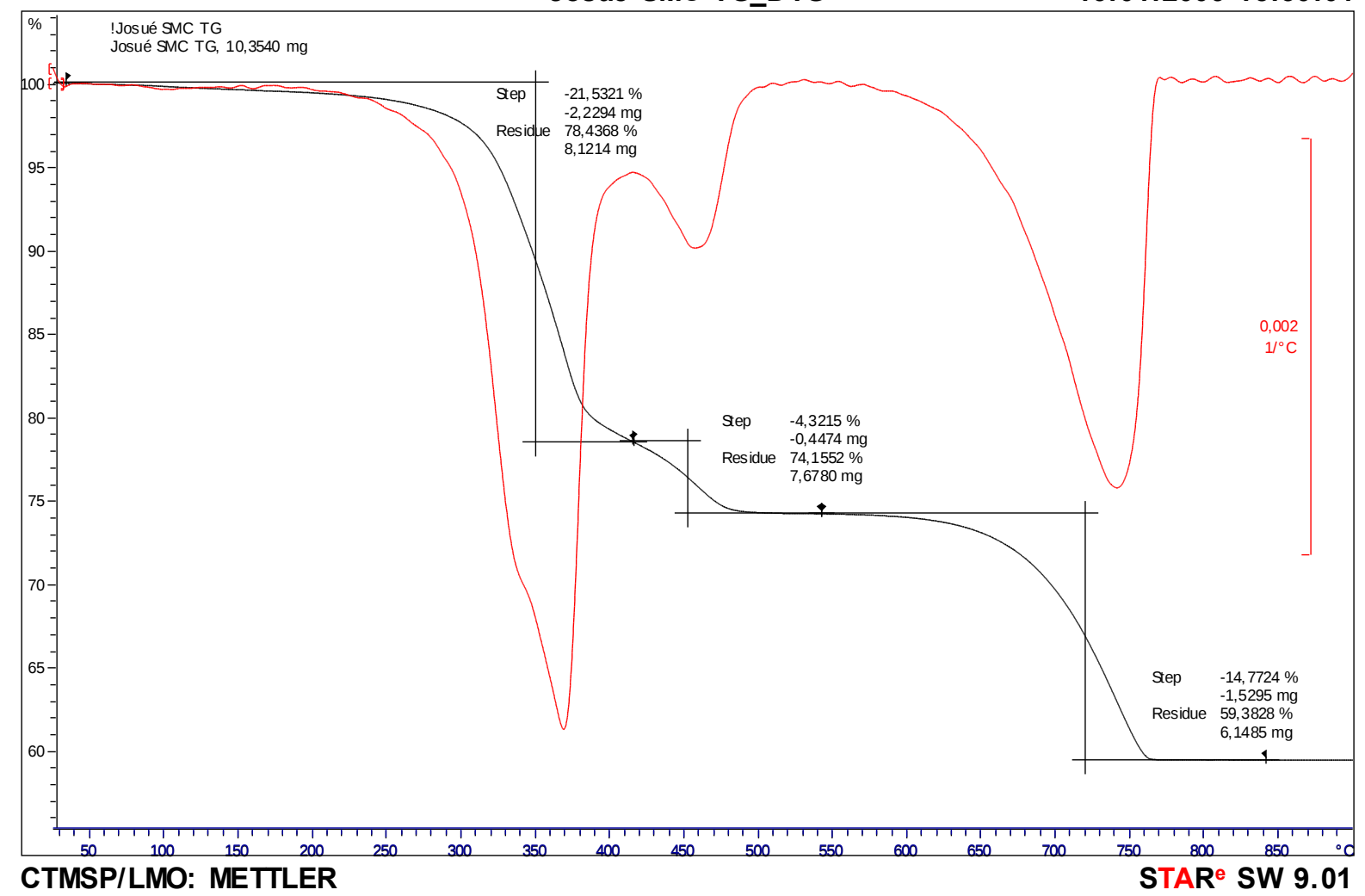

FIGURA 46 - Curva termogravimétrica do substrato de SMC. 
Como o substrato de RMT apresenta a mesma composição química do SMC, pode-se atribuir ao comportamento térmico de ambos os substratos as mesmas propriedades. $\mathrm{Na}$ FIG. 47 observa-se que no primeiro evento houve perda de $38,6 \%$ da massa, no segundo apenas $4,8 \%$ e no último mais $11,0 \%$, restando como resíduo 45,6\% da massa inicial. Utilizando o mesmo raciocínio feito para o SMC tem-se então uma composição percentual de $43,4 \%$ de matriz polimérica, $24,9 \%$ de carga mineral (carbonato de cálcio) e $31,7 \%$ de vidro para o substrato de RTM.

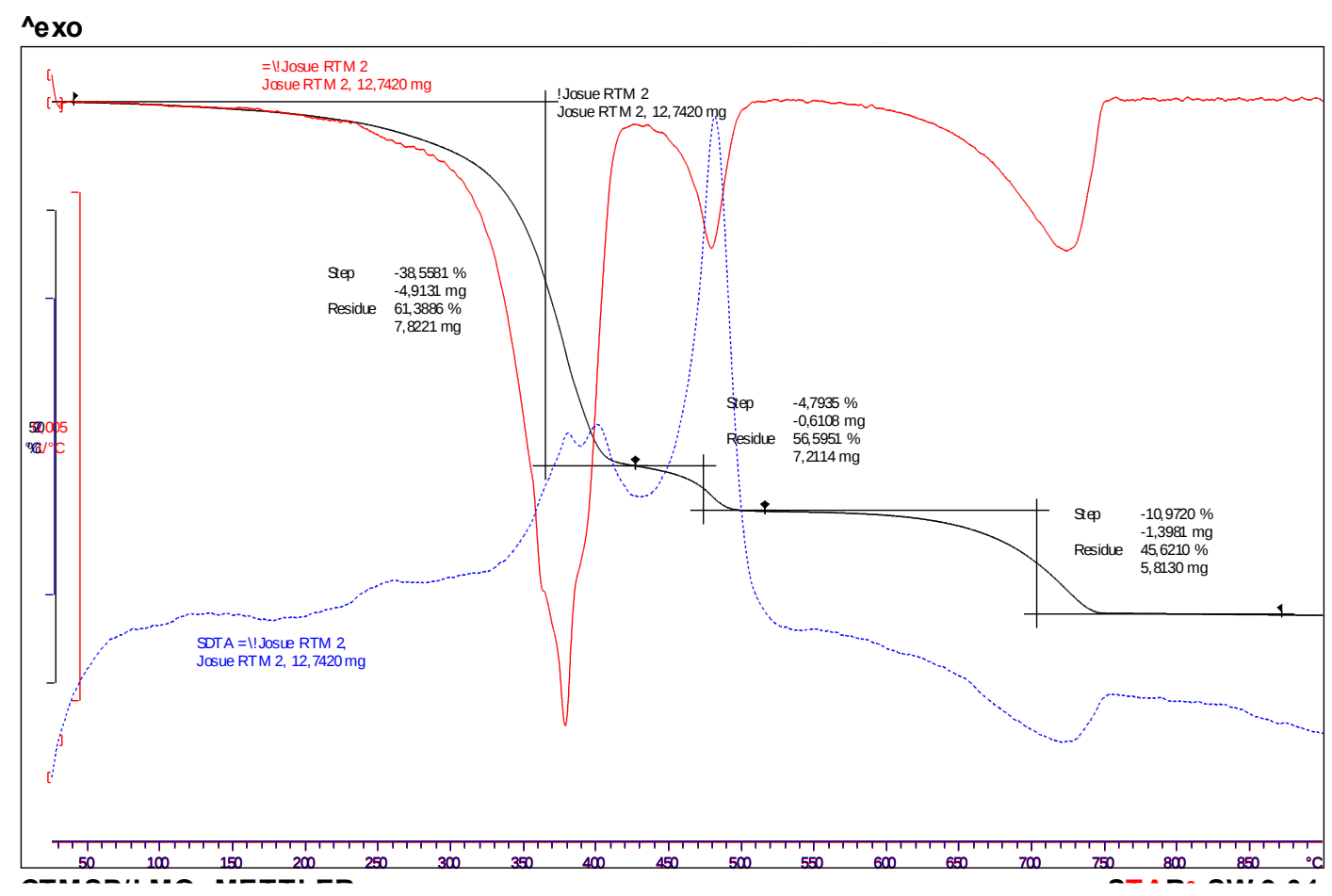

FIGURA 47 - Curva termogravimétrica do substrato de RTM.

As diferentes composições percentuais entre o SMC e o RTM podem ser comparadas para entender o comportamento mecânico destes dois substratos, que embora sejam moldados por processos diferentes, tem os mesmos constituintes básicos, matriz de poliéster, vidro e carga mineral.

Nos ensaios de tensão de ruptura o compósito de SMC apresentou 37,1 MPa, enquanto que o RTM apresentou 55,4 MPa. Analisando as frações de cada um deles temos:

SMC - 25,8\% matriz polimérica, 40,6\% fibra de vidro e 33,6\% carbonato de cálcio RTM - 43,4\% matriz polimérica, 31,7\% fibra de vidro e $24,9 \%$ carbonato de cálcio 
Embora o SMC tenha maior teor de fibras de vidro do que o RTM, apresentou menor tensão de ruptura do que o RTM. Isto se deve a menor quantidade de matriz polimérica que do SMC que comprometeu a impregnação das fibras de vidro, e ao elevado teor de carga mineral.

No substrato de ABS a primeira decomposição resultou na perda de $87,2 \%$ e a segunda decomposição uma perda de 9,6\%, ambas devido à decomposição do polímero. Aparentemente não há presença de carbonato de cálcio, mas há presença de um resíduo que corresponde a 3,2\%, que pode ser atribuído a cargas minerais inertes. A FIG.48 ilustra com mais detalhes estas decomposições.

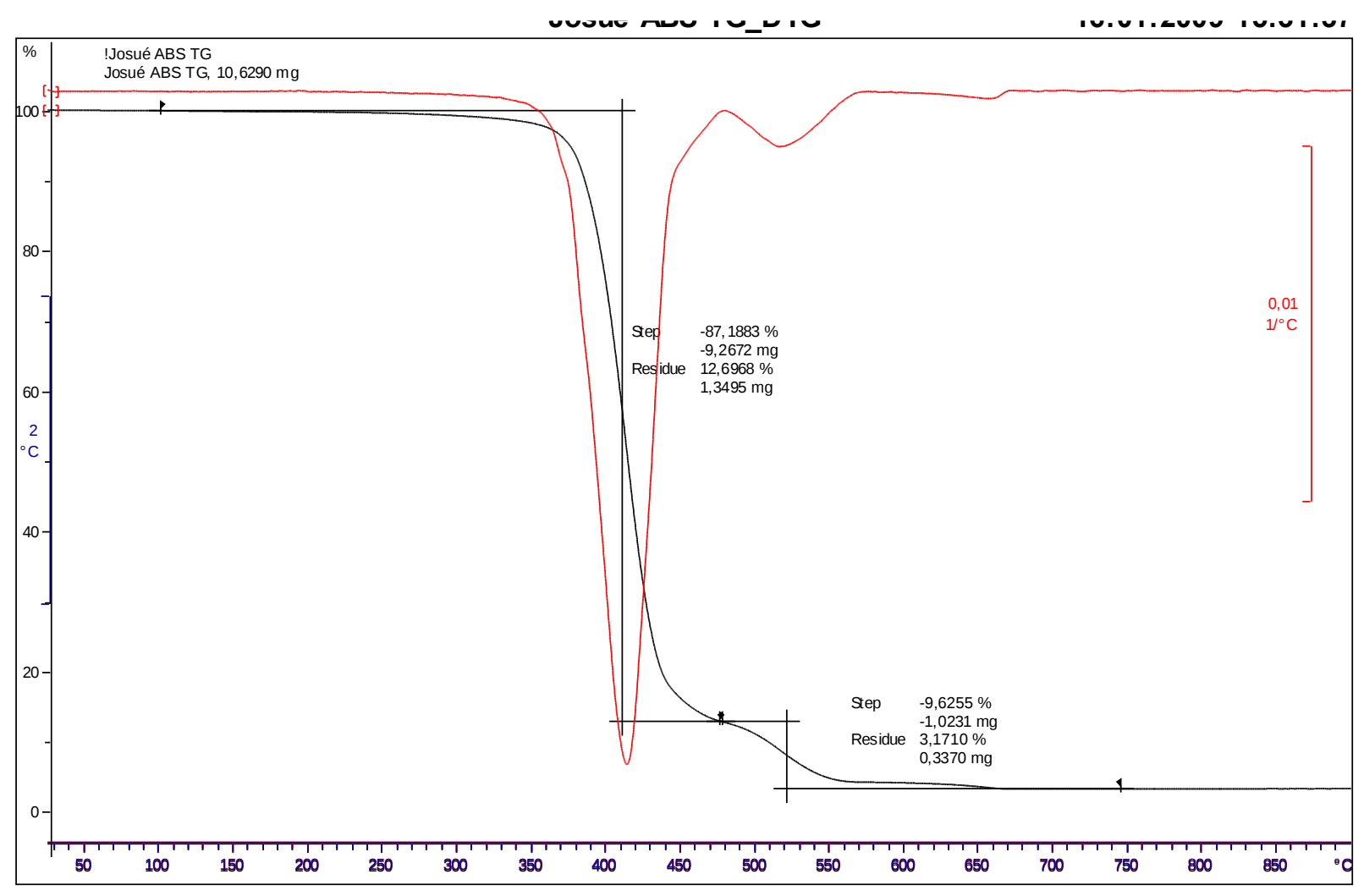

FIGURA 48 Curva termogravimétrica do substrato de ABS.

\subsubsection{Calorimetria diferencial exploratória (DSC)}

O adesivo uretânico é formado pela reação química dos componentes poliol e isocianato, uma reação cujo calor pode ser medido por calorimetria diferencial exploratória (DSC). Os dois componentes foram resfriados a $0^{\circ} \mathrm{C}$ e misturados conforme proporção previamente estipulada. Uma amostra de adesivo foi coletada imediatamente após a mistura e 
preparada para análise. Iniciou-se a programação de aquecimento. A FIG. 49 ilustra o processo de liberação de calor por meio da elevação da temperatura da amostra, feita em três vezes para comparação, não sendo observadas diferenças entre elas.

Por meio deste ensaio pode-se obter o pico exotérmico de reação de $67,7^{\circ} \mathrm{C}$ e pela integração da curva obteve-se que o calor liberado no processo de polimerização foi de

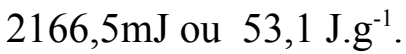

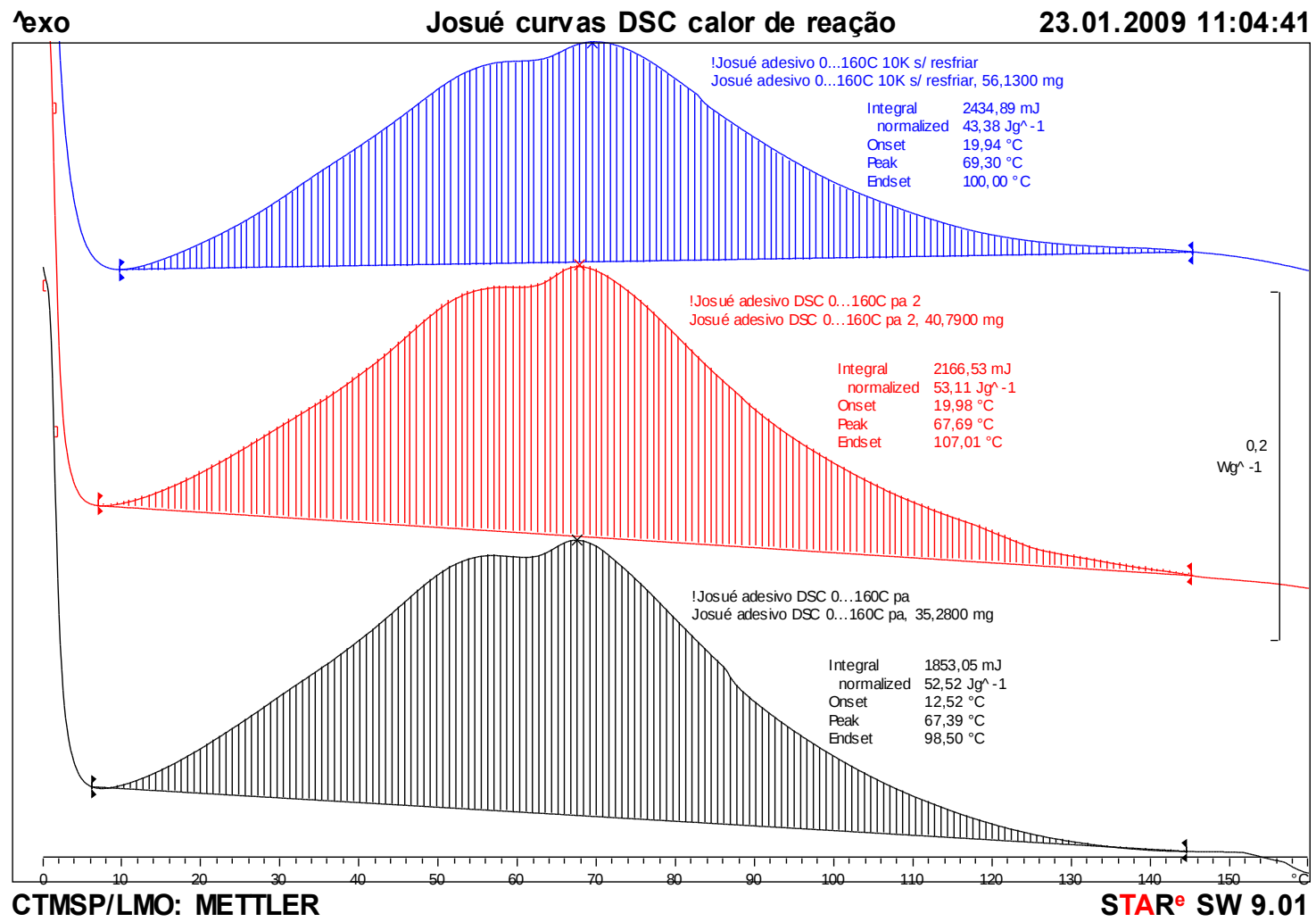

FIGURA 49 - Curva de calorimetria diferencial exploratória da reação entre o poliol e isocianato.

Após a reação e formado o adesivo uretânico, foi feito um estudo utilizando o DSC para avaliar a liberação e absorção de calor da amostra em períodos de 24h, 4 dias e 10 dias na faixa de temperatura de $-20^{\circ} \mathrm{C}$ até $200^{\circ} \mathrm{C}$, que são as temperaturas de trabalho previstas para $\mathrm{o}$ adesivo. A FIG. 50 ilustra este estudo.

Observou-se primeiramente uma mudança na linha de base atribuída a transição vítrea. Esta transição ocorre quando o polímero passa de um estado rígido para um estado flexível. Para o adesivo curado após $24 \mathrm{~h}$ a transição vítrea ocorreu entre 1,57 e $13,41^{\circ} \mathrm{C}$, com ponto 
médio de $9,78^{\circ} \mathrm{C}$. Para o adesivo curado por 4 dias a temperatura ambiente, a transição vítrea ocorreu entre 8,79 e $26,04^{\circ} \mathrm{C}$, com ponto médio a $19,19^{\circ} \mathrm{C}$. Para o adesivo curado por 10 dias a temperatura ambiente, a transição vítrea ocorreu entre 12,96 e $30,69^{\circ} \mathrm{C}$, com ponto médio a $23,03^{\circ} \mathrm{C}$.

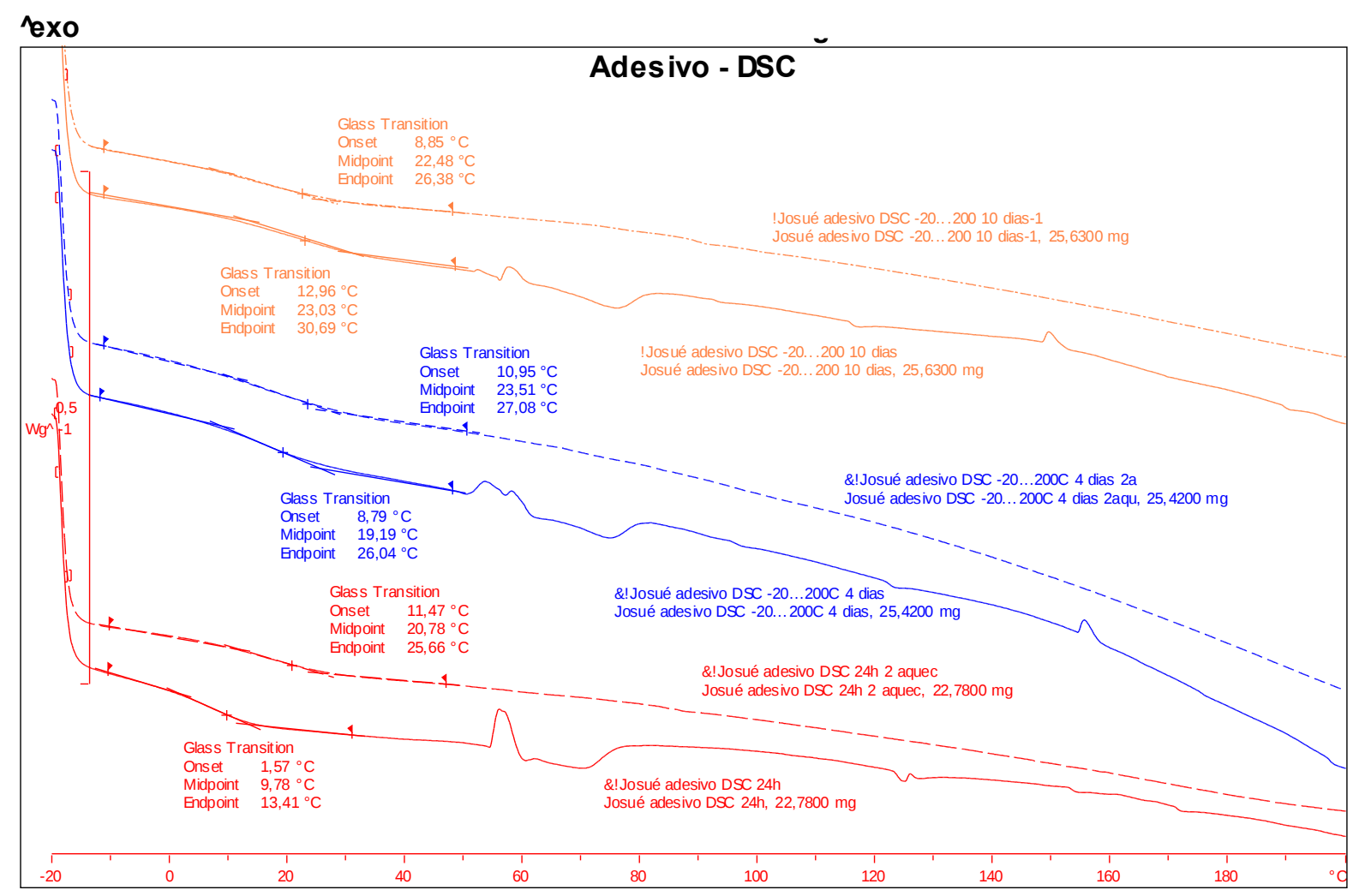

FIGURA 50 - Curva de calorimetria diferencial exploratória do adesivo uretânico curado após $24 \mathrm{~h}, 4$ e 10 dias.

Nota-se um aumento gradual da $\mathrm{T}_{\mathrm{g}}$ com o passar do tempo, variando de $9,78{ }^{\circ} \mathrm{C}$ para $23,03{ }^{\circ} \mathrm{C}$, indicando que o processo de cura do adesivo uretânico continua por alguns dias devido ao aumento das ligações cruzadas. Esta observação está de acordo com o evidenciado nos estudos de resistência ao cisalhamento no item 5.4.2, quando ocorreu um aumento da resistência ao cisalhamento com o passar do tempo. Isto indica que reações químicas ainda ocorrem mesmo após a cura parcial do adesivo uretânico.

Outros eventos também podem ser observados em temperaturas próximas a 55, 65, 120 e $150^{\circ} \mathrm{C}$, os quais podem ser atribuídos a reações de pós cura, porém sem ocorrer degradação térmica, que conforme se observou nos ensaios de termogravimetria o adesivo uretânico começa a degradar-se a partir de $120^{\circ} \mathrm{C}$. 
Por comparação com os resultados obtidos no item 5.4.1.4, onde a resistência ao cisalhamento do adesivo foi avaliada sobre substratos metálicos nas temperaturas de $-40,25$, 80,120 e $177^{\circ} \mathrm{C}$, pode-se notar que na condição a $-40^{\circ} \mathrm{C}$, há um pequeno aumento da resistência ao cisalhamento. Nesta temperatura o adesivo encontra-se abaixo da transição vítrea, ou seja, está mais rígido e as estruturas poliméricas apresentam menor mobilidade, portanto apresenta uma resistência mais elevada ao cisalhamento do que nas outras temperaturas acima desta. O comportamento mecânico na resistência ao cisalhamento nas temperaturas de 25,80 e $120^{\circ} \mathrm{C}$ não sofreu grande alteração, apenas notou-se um grande declínio na condição de $177^{\circ} \mathrm{C}$. Com base nestas informações e avaliando-se a curva DSC, pode-se inferir que um evento endotérmico próximo a $155^{\circ} \mathrm{C}$ fragiliza o adesivo e altera seu comportamento mecânico.

Também se observa uma atenuação destes eventos gradativamente com o passar do tempo, uma vez que os picos e vales são mais intensos no adesivo curado por $24 \mathrm{~h}$ até o adesivo curado por 10 dias. Esta atenuação também é um indicativo que o adesivo passa por um processo de pós-cura em função do tempo.

Efetuou-se também um segundo ensaio com a amostra de adesivo uretânico curado por 24h, 4 e 10 dias, com o intuito de observar a variação da transição vítrea e se os eventos endotérmicos e exotérmicos presentes no primeiro ensaio permaneciam. A FIG.50 ilustra o primeiro aquecimento pela linha contínua e o segundo pela linha pontilhada. As curvas do DSC desse segundo aquecimento do adesivo curado por $24 \mathrm{~h}, 4$ e 10 dias, apresentaram um deslocamento da transição vítrea para uma temperatura mais alta, principalmente para o adesivo curado por apenas $24 \mathrm{~h}$, que apresentou um deslocamento de aproximadamente $10^{\circ} \mathrm{C}$.

A avaliação por calorimetria diferencial exploratória dos substratos foi feita nas mesmas condições utilizadas para o adesivo. Na FIG.51 encontram-se os gráficos dos substratos de ABS, SMC e RTM. Para o primeiro observou-se a transição vítrea em $81,9^{\circ} \mathrm{C}$, enquanto que para o SMC e RTM as $\mathrm{T}_{\mathrm{g}}$ 's foram respectivamente $74,4^{\circ} \mathrm{C}$ e $62,5^{\circ} \mathrm{C}$. Além disso observou-se para o ABS um evento em $110^{\circ} \mathrm{C}$ devido a amolecimento do polímero.

Diferentemente do ocorrido no SMC, o RTM apresentou um evento a $150^{\circ} \mathrm{C}$ e outro a $170^{\circ} \mathrm{C}$, que podem estar associados a degradação do poliéster insaturado formado. 


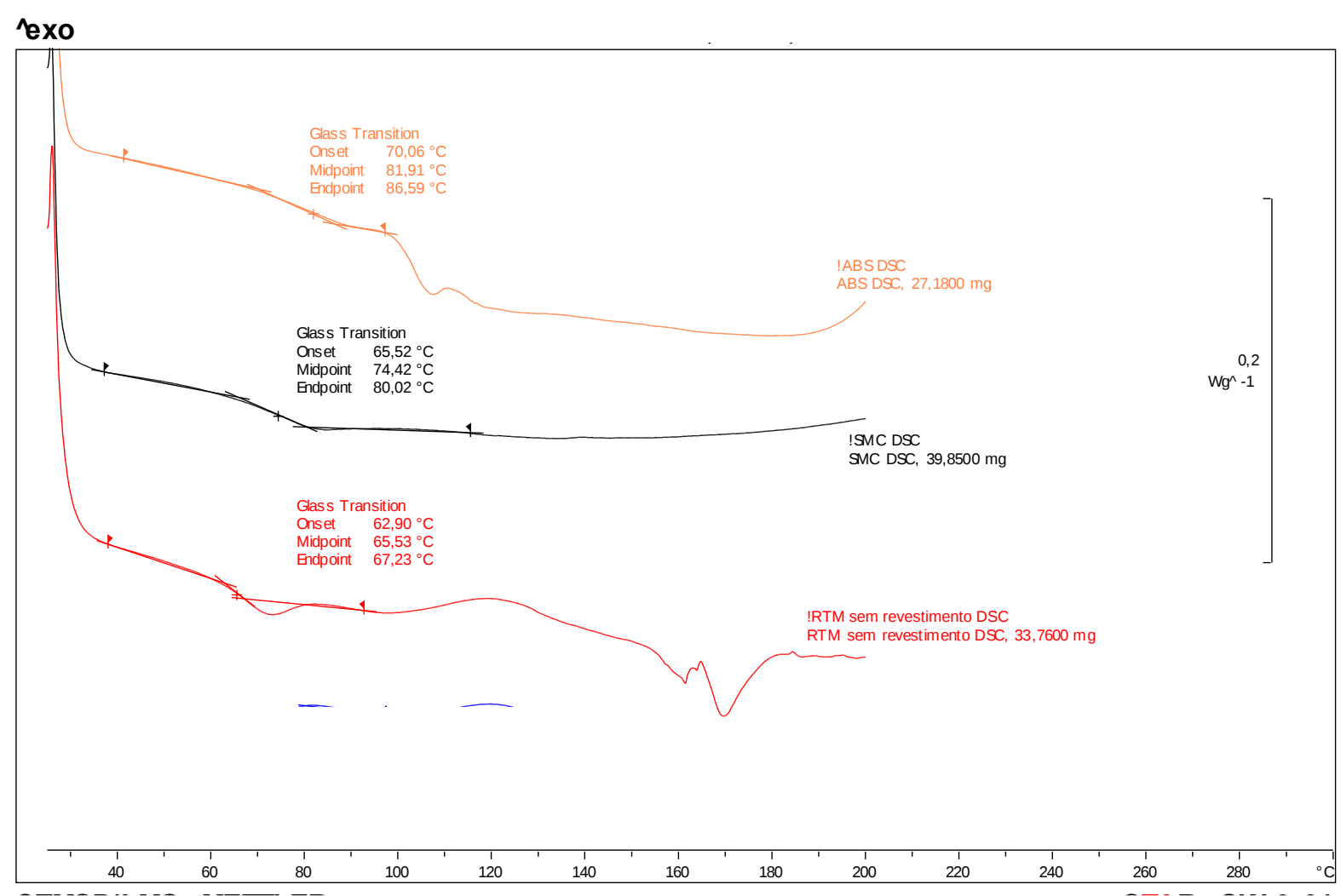

FIGURA 51 - Curva de calorimetria diferencial exploratória dos substratos ABS, SMC e RTM.

7.8. Espectroscopia Vibracional na região do infravermelho por reflectância atenuada (ATR)

O estudo do espectro vibracional na região do infravermelho por reflectância atenuada tem por objetivo a identificação de interações químicas entre o adesivo e a superfície dos substratos. Estas interações químicas podem contribuir para explicar a excelente aderência do adesivo uretânico observada nos substratos anteriormente estudados.

Inicialmente foram estudados individualmente os substratos sem contato com o adesivo para identificação das bandas características dos polímeros presentes na superfície dos substratos. A FIG.52 mostra o espectro do substrato de RTM. 


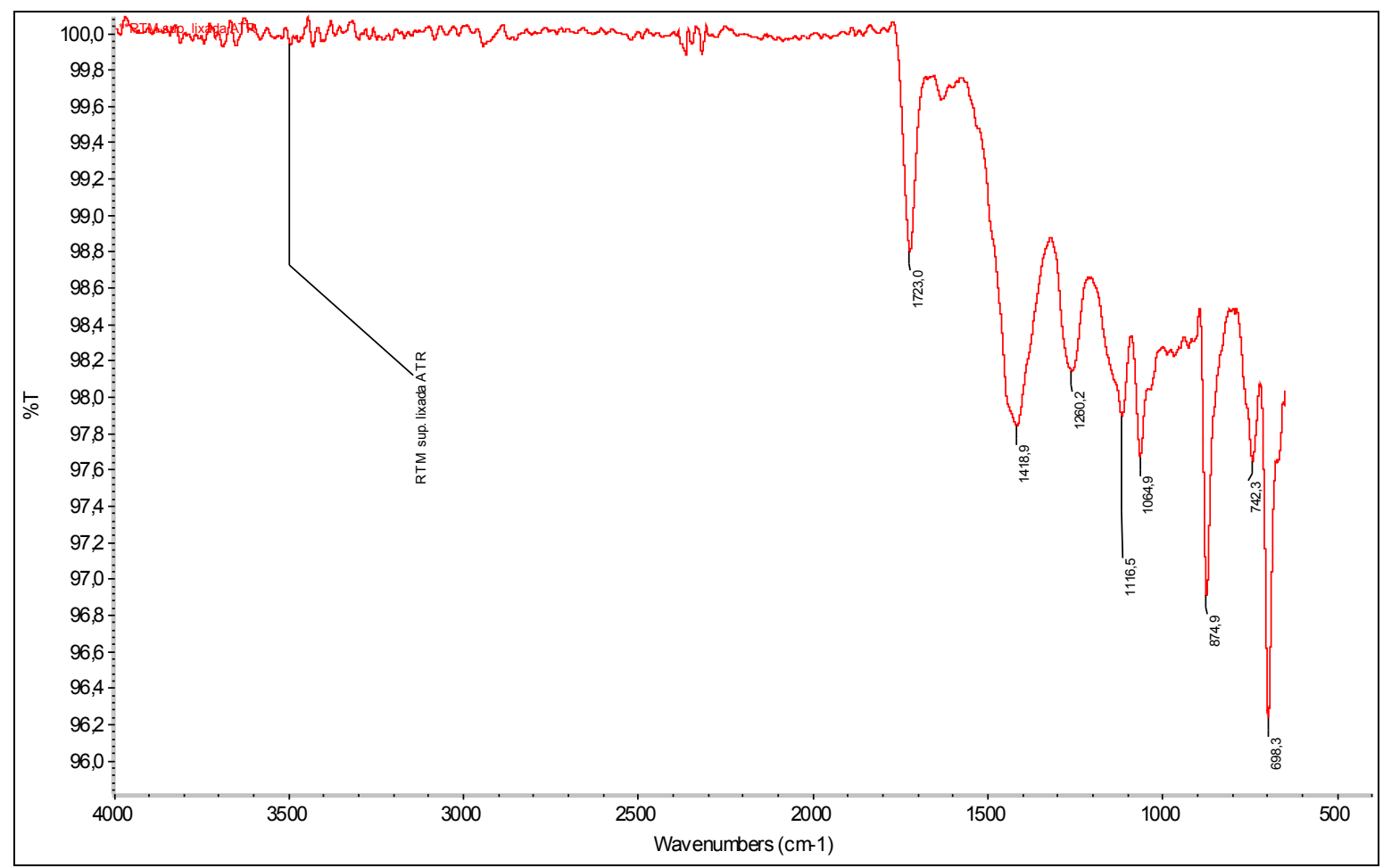

FIGURA 52 - Espectro vibracional na região do infravermelho ATR do substrato de RTM.

De acordo com PAAUW (1991) e SANCHEZ (1996) as principais bandas que caracterizam o poliéster insaturado no substrato de RTM foram observadas em $1723 \mathrm{~cm}^{-1}$ atribuída ao estiramento de $\mathrm{C}=\mathrm{O}$ de ésteres, $1419 \mathrm{~cm}^{-1}$ do anel aromático do estireno e 1260 $\mathrm{cm}^{-1}$ da deformação axial C-O-C de ésteres. Bandas do anel aromático do anidrido ftálico foram observadas em 1065, 875, 742 e $698 \mathrm{~cm}^{-1}$. Embora de pequena intensidade observam-se duas bandas de estiramento de $\mathrm{OH}$ em 3650 e $3690 \mathrm{~cm}^{-1}$ são indicativos da presença deste grupo. Na FIG. 53 está apresentado o espectro do substrato de SMC. 


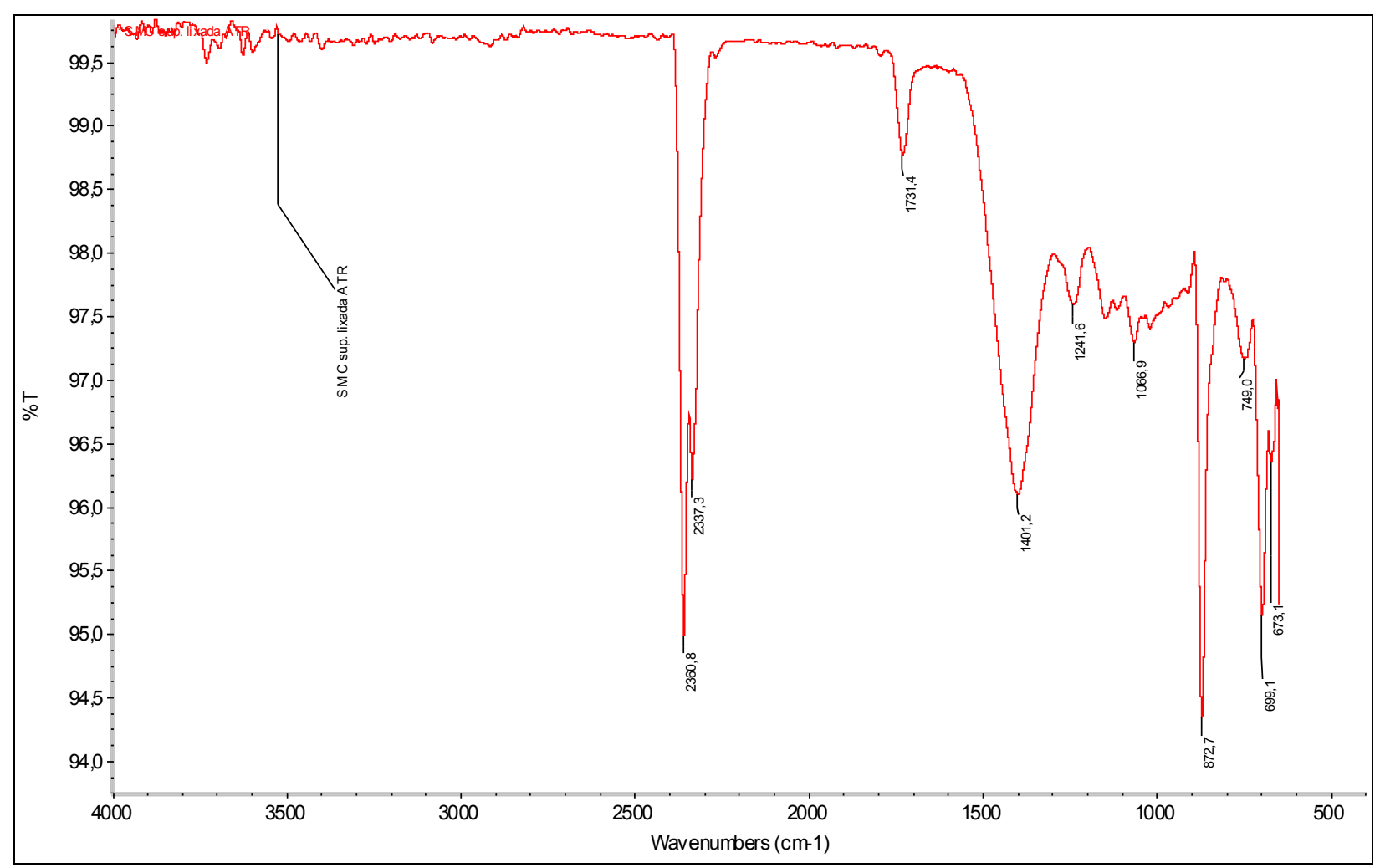

FIGURA 53 - Espectro vibracional na região do infravermelho ATR do substrato de SMC.

Os substratos de RTM e SMC apresentam composições químicas basicamente semelhantes, ou seja, ambos são formados por poliéster insaturado, sendo assim as mesmas bandas foram observadas. As principais são em $1731 \mathrm{~cm}^{-1}$ a banda de estiramento de $\mathrm{C}=\mathrm{O}$ de ésteres, $1401 \mathrm{~cm}^{-1}$ do anel aromático do estireno, $1242 \mathrm{~cm}^{-1}$ de deformação axial C-O-C de ésteres. Bandas do anel aromático do anidrido ftálico foram observadas em 1067, 872, 749, 699 e $673 \mathrm{~cm}^{-1}$. No compósito de SMC também foram observadas bandas relativas ao estiramento de $\mathrm{OH}$ em 3600,3620 e $3730 \mathrm{~cm}^{-1}$.

Na FIG.54 observa-se o espectro do copolímero ABS, formado pela polimerização de acrilonitrila, estireno e butadieno, seu espectro apresentará bandas características destes três monômeros. As principais bandas identificadas foram do estiramento $\mathrm{CH}$ de anel aromático em $3025 \mathrm{~cm}^{-1}$ do estireno, estiramentos de $\mathrm{CH}_{2}$ e $\mathrm{CH}_{3}$ em $2920 \mathrm{~cm}^{-1}$, estiramento de $\mathrm{C} \equiv \mathrm{N}$ da acrilonitrila em $2220 \mathrm{~cm}^{-1}$, deformação angular do $\mathrm{CH}_{2}$ em 1492 e $1448 \mathrm{~cm}^{-1}$ e bandas características do anel aromático em 757 e $697 \mathrm{~cm}^{-1}$. 


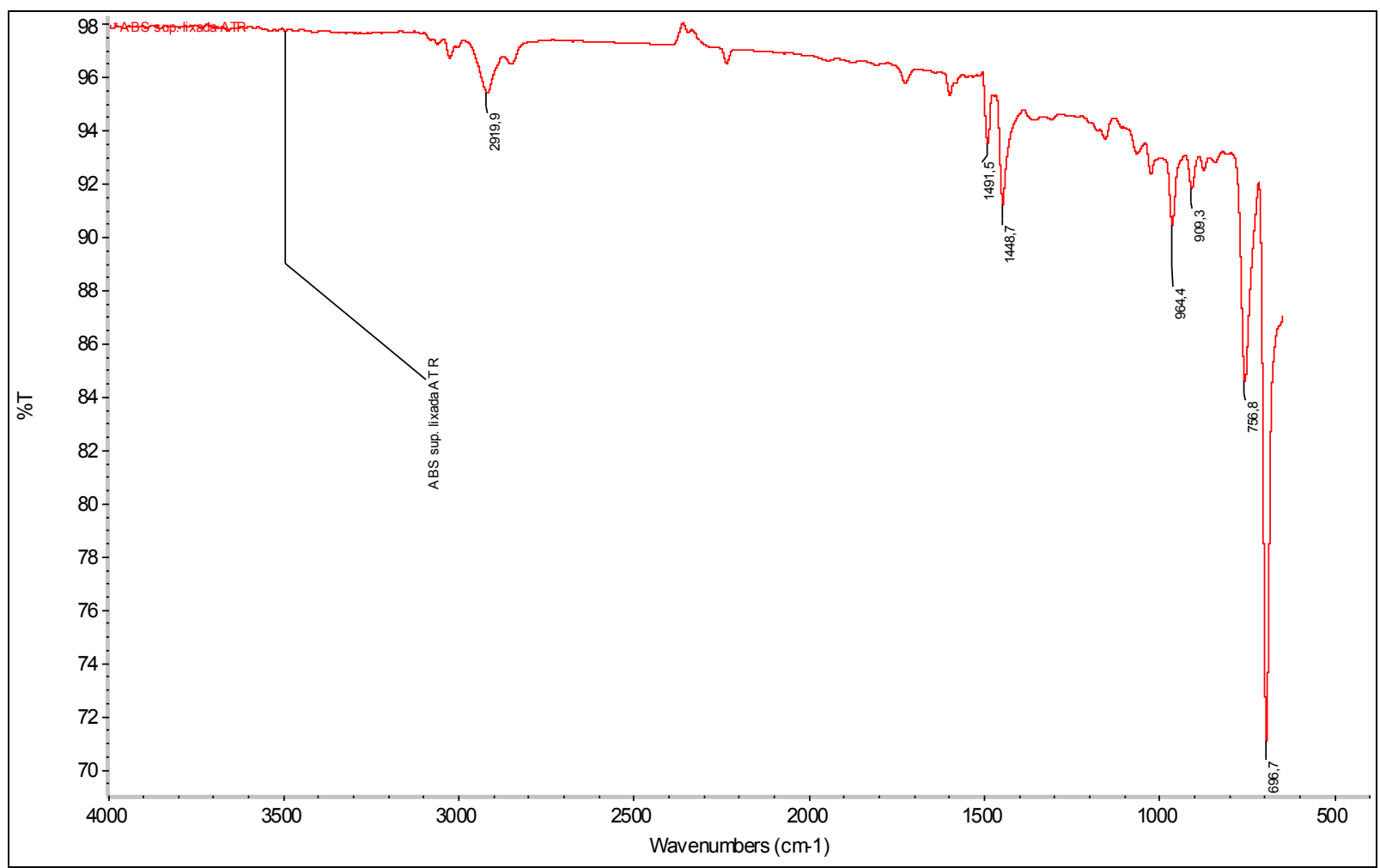

FIGURA 54 - Espectro vibracional na região do infravermelho ATR do substrato de ABS.

O adesivo uretânico, composto pela reação de um poliol com um isocianato, poderá interagir com o substrato através de reações químicas entre o grupo isocianato e grupos reativos da superfície dos substratos. Portanto antes de se investigar a superfície dos substratos após o contato com o isocianato se faz necessário o estudo do isocianato individualmente. $\mathrm{Na}$ FIG. 55 observa-se o espectro individual do componente isocianato do adesivo uretânico. As principais bandas observadas foram em $2304 \mathrm{~cm}^{-1}$ a devido ao estiramento de $\mathrm{N}=\mathrm{C}=\mathrm{O}$, em $1776 \mathrm{~cm}^{-1}$ do estiramento $\mathrm{C}=\mathrm{O}$, além das bandas do $\mathrm{CH}$ do anel aromático em 3692, 3395, 3027, 2917 e $2852 \mathrm{~cm}^{-1}$. (URBANSKI, 1997). 


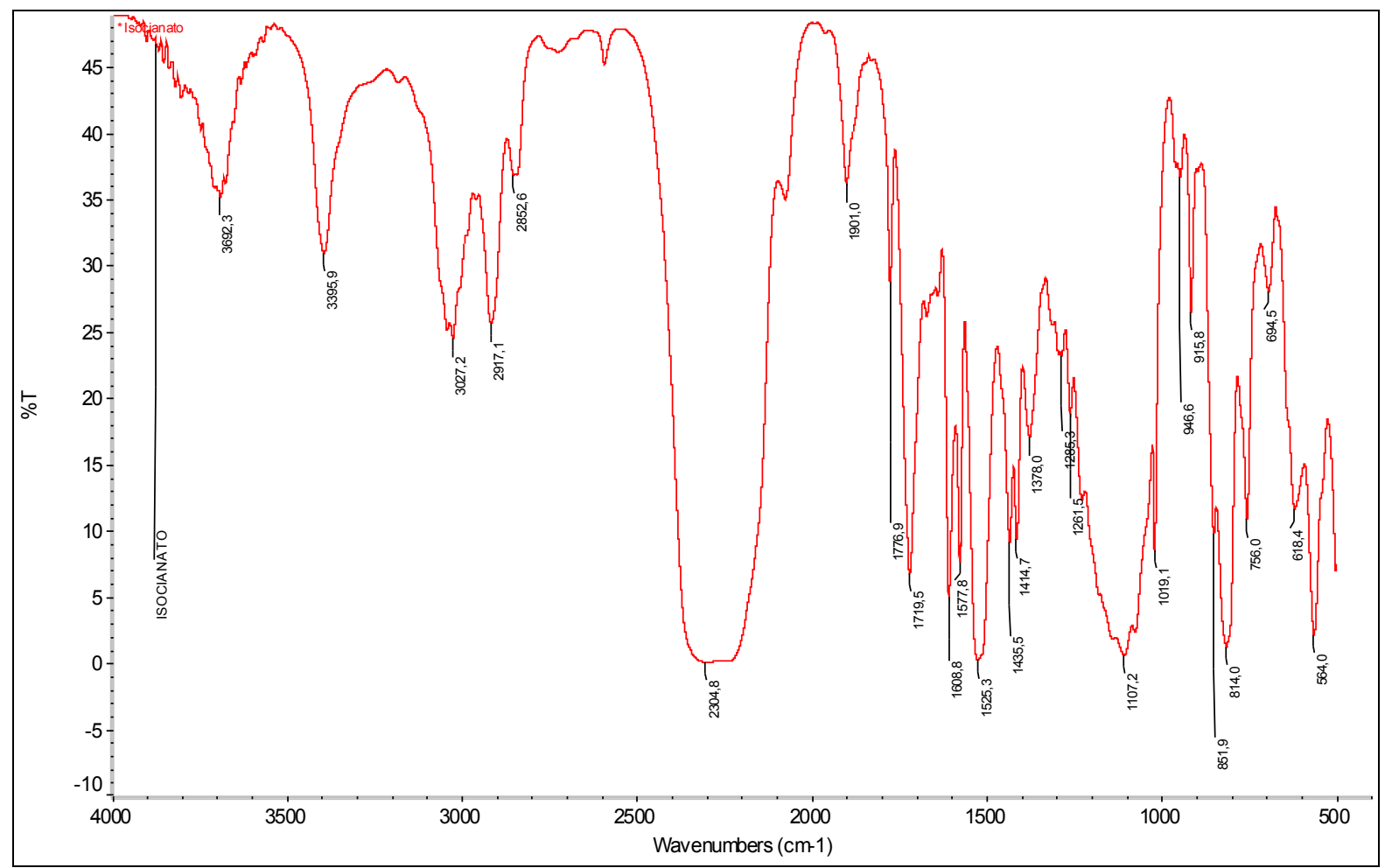

FIGURA 55 - Espectro vibracional na região do infravermelho ATR do isocianato.

Para avaliar a efetiva interação química entre o adesivo uretânico e o substrato, colocou-se uma fina camada de isocianato em contato com a superfície do substrato recém lixada para remoção de possíveis contaminantes. O isocianato ficou em contato com a superfície por um período de $48 \mathrm{~h}$, após este período o excesso de isocianato foi removido e obtiveram-se os espectros. Na FIG. 56 observa-se o espectro do substrato de RTM após contato com o isocianato.

Considerando que o isocianato pudesse reagir com grupos $\mathrm{OH}$ na superfície do substrato de RTM, formando assim a cadeia uretânica, poderiam ser observadas as bandas características deste grupo. De acordo com a literatura, no espectro infravermelho as bandas características do grupo uretânico R-NHCOO-R, ilustrado na FIG.24, seriam o estiramento do $\mathrm{NH}$ em 3250 a $3300 \mathrm{~cm}^{-1}$, estiramento do grupo C=O em 1710 a $1640 \mathrm{~cm}^{-1}$, deformação de $\mathrm{NH}$ em $1510 \mathrm{~cm}^{-1}$, estiramento $\mathrm{CN}$ e deformação $\mathrm{NH}$ em $1530 \mathrm{~cm}^{-1}$. 


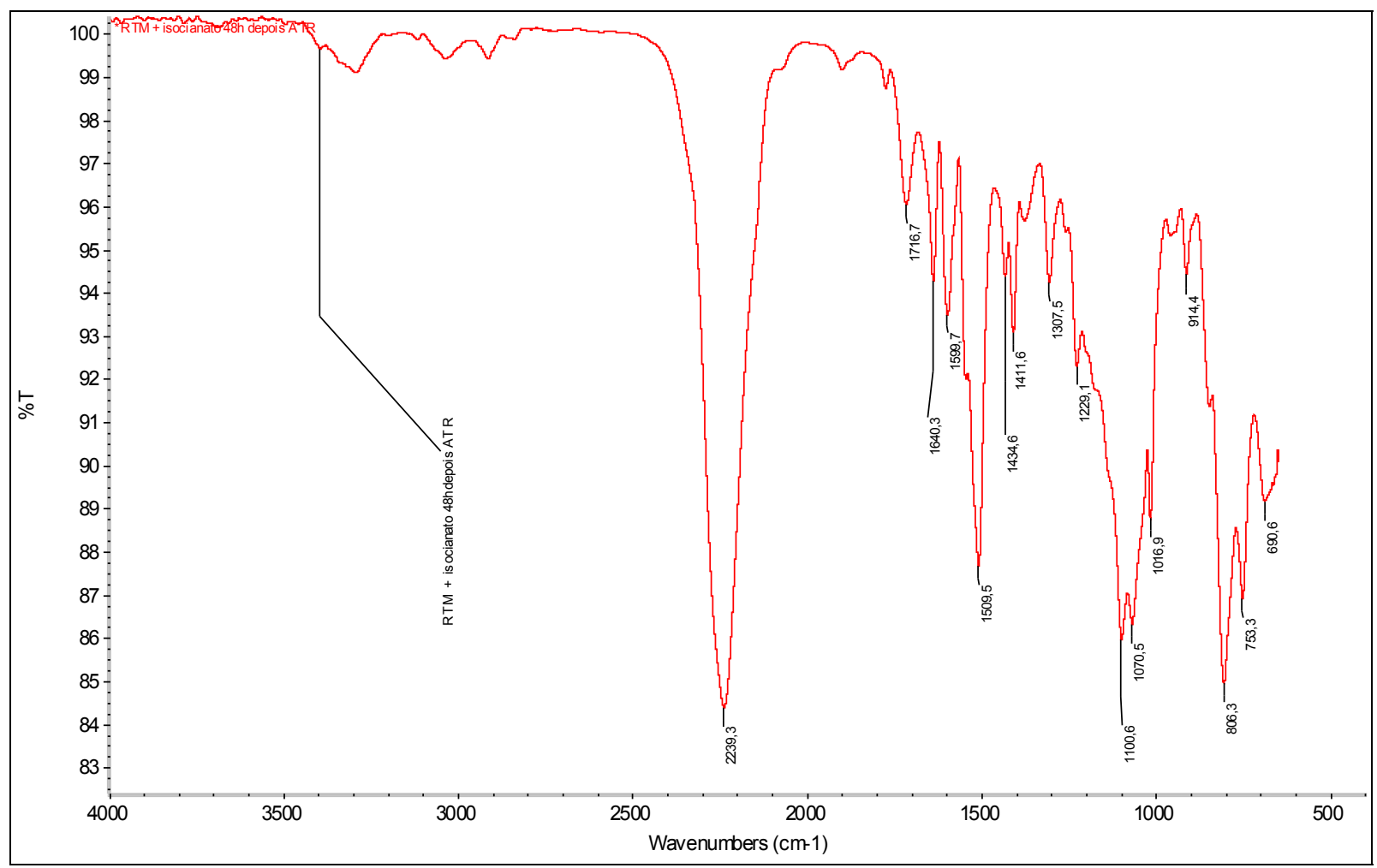

FIGURA 56 - Espectro vibracional na região do infravermelho ATR do substrato de RTM após contato com isocianato.

Analisando o espectro do substrato de RTM após contato com o isocianato pode-se observar todas as bandas do isocianato puro, obviamente porque o excesso de isocianato na superfície do substrato ficou sem reagir. Nas regiões de $1530 \mathrm{~cm}^{-1}$ e de 1710 a $1640 \mathrm{~cm}^{-1}$, onde poderia confirmar a formação de alguma ligação uretânica, ocorrem sobreposições de bandas, tanto do substrato de poliéster quanto do isocianato puro, portanto não podem indicar a formação desta ligação. Porém observaram-se em 3280 e $3300 \mathrm{~cm}^{-1}$, duas pequenas bandas que podem ser atribuídas à formação do grupo $\mathrm{NH}$ e em $1509 \mathrm{~cm}^{-1}$ observase uma banda de deformação de NH. Como estas três bandas não estão nem no isocianato nem no substrato de poliéster atribuímos elas a ligações uretânicas entre o substrato e o isocianato.

$\mathrm{O}$ grupo NH formado indica que o isocianato do adesivo reagiu quimicamente com o substrato de forma semelhante ao que ocorre na reação de polimerização do poliuretano, ilustrada na FIG. 25. Esta observação representa uma prova de que há uma interação química entre o adesivo e o substrato, o que se tratando de um estudo de adesivo é algum muito raro conseguir observar e comprovar que uma reação química tenha ocorrido entre eles. 
A confirmação da ocorrência de uma reação química indica que uma força primária atua entre o adesivo uretânico e o substrato por meio de uma ligação covalente. Estas ligações covalentes apresentam de energia de ligação entre 60 e $700 \mathrm{KJ}^{-m_{0}{ }^{-1}}$. Esta observação explica o porquê as juntas formada pelo adesivo uretânico e o substrato de RTM resistiram tão bem aos diversos ensaios de resistência ao cisalhamento realizados no presente trabalho, sem que fossem observadas falhas adesivas.

A comprovação desta reação consiste em algo inédito no estudo dos adesivos estruturais uretânicos aplicados em substratos poliméricos compósitos, pois até o momento ainda não se podia confirmar a existência de uma interação tão forte, realizada por forças primárias de adesão.

Como o substrato de SMC é composto por uma matriz polimérica de poliéster insaturado, era de se esperar que o adesivo apresentasse a mesma interação química com este substrato. Na FIG.57 observa-se o espectro do substrato de SMC recém lixado após contato com o isocianato por $48 \mathrm{~h}$. Para o substrato de SMC tratado com isocianato, também se observou as bandas do isocianato decorrentes do excesso dele na superfície. Também na região de $1530 \mathrm{~cm}^{-1}$ e 1710 a $1640 \mathrm{~cm}^{-1}$, foram observadas sobreposições de bandas, tanto do substrato de poliéster quanto do isocianato puro, portanto não podem indicar a formação da ligação uretânica.

Neste substrato foi possível observar uma banda característica de estiramento de $\mathrm{NH}$ em $3307 \mathrm{~cm}^{-1}$ e outra em $1508 \mathrm{~cm}^{-1}$ atribuída a deformação de NH. Como estas duas bandas não estão nem no isocianato nem no substrato de poliéster atribuímos a ligações uretânicas entre o substrato e o isocianato, o que também pode ser usado para explicar a elevada resistência demonstrada nos estudos de resistência ao cisalhamento de juntas formadas por substratos de SMC com adesivo uretânico.

As interações entre adesivo e os substratos de SMC e RTM ocorrem devido a presença de uma força primária do tipo ligação covalente que tem energia de ligação entre 60 a 700 KJ.mol ${ }^{-1}$, comumente presente em adesivos estruturais. 


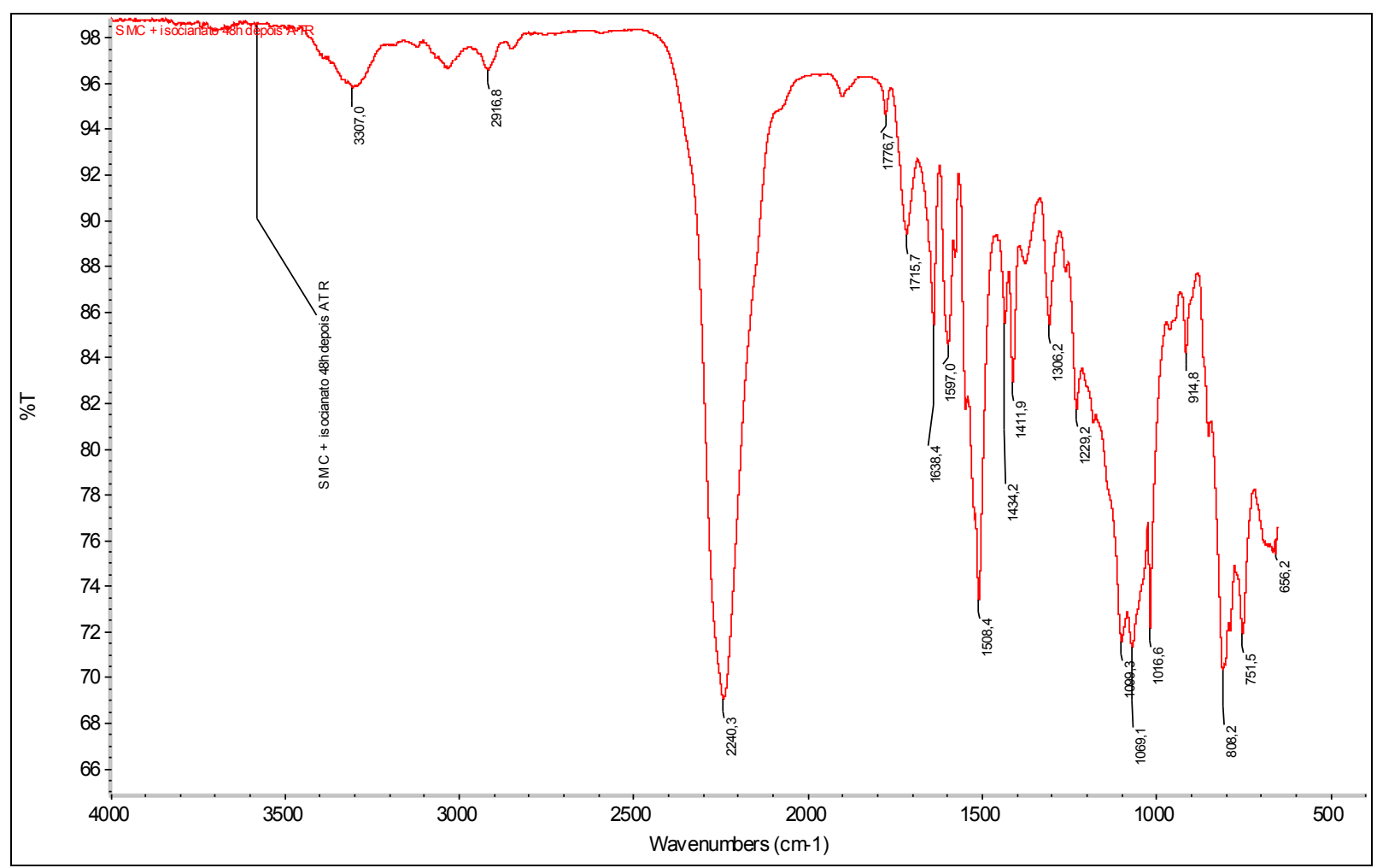

FIGURA 57 - Espectro vibracional na região do infravermelho ATR do substrato de SMC após contato com isocianato.

O estudo prosseguiu para o substrato de ABS e na FIG. 58 observa-se o espectro do substrato após o contato com o isocianato. Quimicamente diferente dos substratos de SMC e RTM o substrato de ABS não tem grupos $\mathrm{OH}$ disponíveis para ligações uretânicas porém foram observadas as bandas de estiramento de $\mathrm{NH}$ em $3300 \mathrm{~cm}^{-1}$ e outra em $1510 \mathrm{~cm}^{-1}$ atribuída a deformação de NH. Este grupo NH formou-se devido a ocorrência de ligações de hidrogênio entre o $\mathrm{N}$ da acrilonitrila e $\mathrm{H}$ do isocianato. Neste caso observa-se a interação adesivo substrato de $\mathrm{ABS}$ devido à força secundária de ligação de hidrogênio que tem energia de ligação em torno de $40 \mathrm{KJ} . \mathrm{mol}^{-1}$. 




FIGURA 58 - Espectro vibracional na região do infravermelho ATR do substrato de ABS após contato com isocianato. 


\section{Conclusão}

As juntas formadas com o adesivo uretânico tiveram um ótimo desempenho nas diferentes condições de exposição, tais como, umidade, névoa salina, envelhecimento acelerador por temperatura, ensaios realizados em diferentes temperaturas e ciclos de exposição combinando diferentes condições, destacando que os ensaios de resistência ao cisalhamento apresentaram ruptura no substrato. Tal desempenho o coloca plenamente adequado para uso em colagens de peças automotivas com os substratos estudados neste trabalho.

O presente trabalho levou ao desenvolvimento de dois novos métodos inovadores de preparação de superfície, um por desengraxe com solvente e outro por plasma, que oferecem uma contribuição para melhorar processos industriais reduzindo tempo de preparação e geração de poeira.

A Termogravimetria foi utilizada como ferramenta para o desenvolvimento de métodos de controle de qualidade na fabricação do adesivo e dos substratos, onde de maneira rápida e precisa, pode-se determinar as frações de massa de matriz polimérica, fibras de vidro e cargas minerais.

Embora a $T_{g}$ do adesivo seja abaixo da temperatura de uso ele pode perfeitamente ser usado como adesivo estrutural para os substratos poliméricos, que apresentam $T_{\mathrm{g}}$ mais elevadas.

Pelo uso da calorimetria diferencial exploratória foi determinada a energia liberada na reação de formação do adesivo uretânico e o seu pico exotérmico. Os ensaios do adesivo após a reação inicial mostraram que o adesivo continua em processo de cura até 10 dias pelo aumento gradual da $T_{g}$. Nos substratos RTM e SMC foi determinada a $T_{g}$ e para o ABS a temperatura de amolecimento, que são usadas como referencial de temperatura máxima de exposição e estão bem abaixo da observada para o adesivo.

Os estudos de espectroscopia na região do infravermelho por reflectância atenuada mostraram as bandas características do poliuretano no adesivo estrutural. Para os compósitos de SMC e RTM como são formados pela mesma matriz polimérica base, apresentaram as bandas características do poliéster insaturado e para o ABS as bandas características do acrilonitrila - butadieno - estireno. 
A espectroscopia na região do infravermelho dos substratos poliméricos após contato com o isocianato do adesivo uretânico revelou que ocorrem reações químicas na superfície, comprovado pela presença de bandas de $\mathrm{NH}$, ausentes nos substratos e no adesivo. Tais reações químicas são responsáveis pela eficiente união do adesivo com os substratos, explicando desta forma o porquê do fenômeno de aderência entre o adesivo uretânico e os substratos avaliados.

Os resultados de todos os ensaios e análises levam à conclusão final que o adesivo uretânico, embora muitas vezes não considerado como estrutural, é um candidato plenamente capacitado ao trabalho de adesão estrutural, especialmente para uso automotivo nas condições descritas neste trabalho.

\section{Sugestões para trabalhos futuros}

Sabendo que a indústria automotiva utiliza outros substratos poliméricos em seus processos, muitos deles de difícil adesão, como por exemplo polietileno, polietileno de alta densidade e polipropileno, sugerimos estudos de tratamentos de superfícies para tais substratos com uso do adesivo uretânico, ampliando assim o campo de aplicação deste adesivo.

Até o momento os adesivo estruturais uretânicos não tem sido usados como tal para uniões de substratos metálicos, porém sugerimos que possam ser investigadas formulações que possibilitem aumentar a resistência ao cisalhamento e assim torna-lo aplicável ao uniões metálicas. 


\section{Bibliografia}

ADDAM, N.K. The physics and chemistry of surfaces, s.ed., n. 9, London, Oxford University Press, 1941.

ADDERLEY, C. S. Adhesive bonding. Mat. Design., v. 9, n. 5, p. 287-293, 1988.

AHAgon, A.; GENT, A.N. J. Pol. Sci., Polym. Phys. ed.13, p. 1285, 1975

ALMEIDA, H.C.;SILVEIRA, C.B.;ERNANI, P.R.; CAMPOS， M.L.;ALMEIDA， D., Composição química de um residuo alcalino da industria de papel e celulose. Quim.Nova, v.30, n.7, p. 1669-1672, 2007

AL-QURESHI, H.A., Composite materials: fabrication and analysis, 3 ed. São José dos Campos, s. ed., 1984.

AMERICAN SOCIETY FOR TESTING AND MATERIALS. Standard practice for operating salt spray apparatus. ASTM, 2007 (ASTM B117-07)

AMERICAN SOCIETY FOR TESTING AND MATERIALS. Standard Test Method for Tensile Properties of Adhesive Bonds. ASTM, 2001 (ASTM D897-01)

AMERICAN SOCIETY FOR TESTING AND MATERIALS. Standard Test Method for Apparent Shear Strength of Single-Lap-Joint Adhesively Bonded Metal Specimens by Tension Loading (Metal-to-Metal). ASTM, 2005 (ASTM D1002-05)

AMERICAN SOCIETY FOR TESTING AND MATERIALS. Standard Test Method for Cleavage Strength of Metal-to-Metal Adhesive Bonds. ASTM, 2002 (ASTM D1062-02)

AMERICAN SOCIETY FOR TESTING AND MATERIALS. Standard Test Method for Tensile Properties of Polymer Matrix Composite Materials. ASTM, 2007 (ASTM D3039-07)

AMERICAN SOCIETY FOR TESTING AND MATERIALS. Standard Test Method for Determining Strength of Adhesively Bonded Rigid Plastic Lap-Shear Joints in Shear by Tension. ASTM, 2001 (ASTM D3163-01)

AMERICAN SOCIETY FOR TESTING AND MATERIALS. Standard Test Method for Tension Testing of Metallic Materials. ASTM, 2000 (ASTM E8M)

ARGAWAL, B.D.; BROUTMAN, L.J., Analysis and performance of fiber composites, John Wiley \& Sons, p. 4, 1980.

ASHCROFT, I.A.; WAHAB, M.M.A.; CROCOMBE, A.D.; HUGHES, D.J.; SHAW, S.J., The effect of environmental on the fatigue of bonded composite joints. Part 1: testing and fractography. Comp., v. 32, p. 45-58, 2001.

ASM International, Composites. Engineered Materials Handbook, v. 1, USA, p. 7, 23-27, 1987. 
BADER, S., Crystic-composite handbook, s. ed., 2003.

BAIER, R.E. Adhesion: Mechanisms that assist or impede it, Science, v. 162, p. 1360-1368, 1968.

BAKER, A.A.; CHESTER, R.J. Minimum surface treatments for adhesively bonded repairs, Int. J. Adhesion and Adhesives,v. 12, n. 2 p. 73-78, 1992.

BALDAN, A. Adhesively-bonded joints in metallic alloys, polymers and composite materials: Mechanical and environmental durability performance. J. Mat. Sci., v. 39, p. 4729 - 4797, 2004.

BALKOVA, R.; HOLCNEROVA, S.; CECH, V. Testing of adhesives for bonding of polymer composites. Int. J. Adhesion and Adhesives, v. 22, p. 291-295, 2002.

BARTHOLOMEUZ, R.A.; BAKER, A.A.; CHESTER, R.J.; SEARL, A. Bonded joints with through-thickness adhesive stress - reinforcing the F/A-18 Y470.5 bulkhead. Int. J. Adhesion and Adhesives, v. 19, p. 173-180, 1999.

BIEKERMAN, J.J. The science of adhesive joints, s.ed., New York, Academic Press, 1961.

BIENK, E.J.; MIKKELSEN, N.J. Apliccation of advanced surface treatment technology in the modern plastics moulding industry, Wear, v. 207, p. 6-9, 1997.

BOERIO, F.J.; WILLIANS, J.W. Structure and properties of organosilane primers for adhesive bonding. Appl. Surf. Sc., v. 7, p. 19-31, 1981.

BRADY, G.S.; CLAUSER, H.R.; VACCARI, J.A. Materials Handbook, 15 ed. New York, N.Y., McGraw-Hill, 2002.

BROUGHTON, J.G.; FESSEL, G.; FELLOWS, N.A.; DURODOLA, J.F.; HUTCHINSON, A.R. Evaluation of different lap-shear joint geometries for automotive applications. Int. J. Adhesion and Adhesives, v. 27, p. 574-583, 2007.

CHAN, C.-M.; HIRAOKA, H.; KO, T.-M. Polymer surface modification by plasmas and photons. Surf. Sc. Rep, v. 24, p. 1-54, 1996.

CHASTAIN, C.E. Desiging adhesive joints, Appliance Engineer, v.8, n. 4, p. 22-25, 1974.

COGNARD, P. Handbook of adhesives and sealants, 1.ed, v. 2, Versailles, France, Elsevier, 2006.

DILETA, Descritivo de componentes e utilização da câmara de teste acelerado de corrosão em névoa salina (Salt spray), Rev. 01 de 06/2007.

DODIUK, H.; KENIG, S. The effect of surface preparation on the performance of acrylic adhesive joints. Int.J.Adhesion and Adhesives, v. 8, n. 3, p. 159-166, 1988.

DUNOUY, P.; LECOUNTE, J. Gen. Physiol., v. 1, p. 521, 1919. 
EDWARDS, K.L. A brief insite into the selection and use of engineering adhesives for preliminary joint design. Mat.Design., n. 19, p.121-123, 1998.

ELEKEIROZ, Manual básico do poliéster insaturado, s. ed., s. data.

EMRANI, M.Al-; KLIGER, R. Analysis of interfacial shear stress em beams strengthened with bonded prestressed laminates. Comp. Part B, n. 37, p. 265-272, 2006.

FERNLUND, G.; SPELT, J.K. Failure load prediction of structural adhesive joints. Int.J.Adhesion and Adhesives, v. 11, n. 4, p. 213-220, 1991.

FELISBERTI, M.I., TURCHET, R.; Caracterização composicional do AES - um copolímero de enxertia de poli(estireno-co-acrilonitrila) em poli(etileno-co-propileno-co-dieno), Polímeros, vol16, n. 2, 2006

FIGUEIREDO, E.M., BMC E SMC, Owens corning, s. de., s. data.

FOX, H.W.; ZISMAN, W.A. J.Colloid. Science, n.5, p. 514, 1950.

GOEIJ, W.C.; VAN TOOREN, M.J.L.; BEUKERS, A., Composite adhesive joints under cyclic loading. Mat.Des., v. 20, p. 213-221, 1999.

GRIGNON, J.; KAMENETZKY, D.; TAUZIA, J.M.; BARATCHART, M.; VILLENAVE, J.J Perfecting a polyurethane-type structural adhesive. Int.J.Adhesion and Adhesives, v. 6, n. 4, p. 181-184, 1986.

HARKINGS, W.D.; BROWN, R.E. Physical Chemistry of Surface Films, s. ed., New York, Reinhold Publishing, 1952.

KAPLAN, S.L.; ROSE, P.W. Plasma surface treatment of plastics to enhance adhesion, Int. $\boldsymbol{J}$. Adhesion and Adhesive, v. 11, n. 2, p. 109-113, 1991.

KINLOCH, A.J.; LITTLE, M.S.G., WATTS, J.F., The role of interphase en the environmental failure of adhesive joints. Acta Mater., v. 48, p.4543-4553, 2000.

KIRSCH, D. How to choose a static mixer, Adhesives Age, 2002.

KONATE, Y., Influence of thermal cycle on resistance to fracture under shear loading of adhesives film, Int. J. Adhesion and Adhesive, v. 14, n. 3, p. 181-184, 1994.

KOVACEVID, V.; SMIT, I.; HACE D.; SUCESKA, M.; MUDRI, I.; BRAVAR, M. Role of the polyurethane component in the adhesive composition on the hydrolytic stability of the adhesive. Int. J. Adhesion and Adhesive, v. 13, n. 2, p. 126-136, 1993.

KOVAKEVIK, V.; HACE, D.; BRAVAR, M.; STANOJEVIK D. Correlation between mechanical and chemical properties of polyurethane compounds under ageing conditions. Pol. Degr. Stab, v. 24, p. 349-360, 1989.

LEE, Y., Adhesives and sealents for severe environments, Int. J. Adhesion and Adhesive, v. 7, n. 2, p. 81-91, 1987. 
LEE, Y., The use of fluoroepoxy compounds as adhesives to bond fluoroplastics without surface treatment, Sample Quaterly, v. 19, n. 3, 1988.

LEES, W.A., Bonding composites, Int. J. Adhesion and Adhesives, v. 6, n. 4, p.171 - 180, 1986.

LIQUID CONTROL CORP., Meter, mix and dispense equipment Engineering Handbook, s. ed., 1996.

MALUCELliA, G.; PRIOLlA, A; FERREROA, F.; QUAGLIA, A.; FRIGIONEB, M.; CARFAGNAC, C. Polyurethane resin-based adhesives: curing reaction and properties of cured systems. Int. J. Adhesion and Adhesives, v. 25, p. 87-91, 2005.

MARINUCCI, G., Apostila do curso TNM 5796 - Materias compósitos polimérico: fundamentos, tecnologia e aplicações, IPEN/SP, 2007.

MASTERPOL ADESIVOS. Catálogo Masterpur Estrutural. Disponível em: $<$ http//www.masterpol.com.br/arearestrita $>$. Acesso em 23 mar. 2011.

MATS, C. Optimization of the durability of structural titanium adhesive joints, Int.J.Adhesion and Adhesives, v. 8, n. 1, p. 17-24, 1988.

MESYATS, G.; KLYACHKIN, Y.; GAVRILOV,N.; KONDYURIN, A. Adhesion of polytetrafluorethylene modified by an ion beam. Vac. v. 52, p. 285-289, 1999.

MORGANELLI, R.; CHENG, H. New methacrylates match two part urethane and epoxy performance, Adhesives Age, 1998

MYLAVARAPU, P.; WOLDESENBET, E. Non-destrutive characterization of bondlines in composite adhesive joints, J. Adhesion Sci. Technol., v. 20, n. 7, p. 647-660, 2006.

NIE, H.Y.; WALZAK, M.J.; BERNO, B.; McINTYRE, N.S. Atomic force microscopy study of polypropylene surfaces treated by UV and ozone ... Appl. Surf. Sc., v. 144-145, p 627-632, 1999.

PAAUW, M. Pizzi, A.FT-IR analysis method for simple unsaturated polyesters, J.Appl.Polym.Sci., 42 (1991)1377.

PARKER, B.M. Adhesive bonding of fibre-reinforced composites. Int.J.Adhesion and Adhesives, v. 14, n. 2, p. 137-143, 1994.

PAYNE, H. F. Organic Coating Technology, 2. ed. New York, John Willey \& Sons, 1964,

PETRIE, E.W. Handbook of Adhesives and Sealants, 1. ed. New York, N.Y., McGraw-Hill, 2000 .

PETRIE, E.W. Epoxy Adhesive Formulations, 1. ed. New York, N.Y., McGraw-Hill, 2006. 
POCIUS, A.V. Adhesion and adhesives technology, s. ed., c. 6, New York, Hanser Publishiers, 1997.

QIN, R.Y.; SCHREIBER, H.P. Adhesion at partially restructured polymer surfaces. Coll. Surf., v. 156, p. 85-93, 1999.

QUINI, J.G. Adesivos estruturais uretânicos e sua aplicação em compósitos, R. Plástico Reforçado, n.44, p. 44-48, 2005.

SANCHEZ, M.R.; BLAS, M.M.P.; MARTINEZ, J.M.M.; WALZAK, M.J. Addition of ozone in the UV radiation treatment of a synthetic SBS ruber. Int.J.Adhesion and Adhesives, v. 25, p. 358-370, 2005.

SHANAHAN, M.E.R.; DELAMAR, M.; NGUYEN, T.T., Failure mode and ageing of steel/epoxy joints. Appl. S. Sc., v. 134, p. 202-212, 1998.

SANCHEZ, E.M.S., Resinas de polyester insaturado: relação e propriedades. Influência da adição de copolímero poli(estireno-b-isopreno-b-estireno) nas propriedades mecânicas das resinas, Tese de Doutorado, UNICAMP, Campinas, 1996, p. 106.

SHARPE, L.H. The materials, processes and design methods for assembling with adhesives, Machine Design, p. 178-200, 1966

SCHENEBERGER, G.L. Chemical aspects of adhesive bonding, Part II: Physical properties, Adhesives Age, 1970

SHEPPARD, A.; KELLY, D.; TONG, L. A damage zone model for the failure analysis of adhesively bonded joints. Int.J.Adhesion and Adhesives, v. 18, p. 385-400, 1998.

SHIELDS, J. Adhesives Hanbook, 2.ed. London, U.K., Butterworth \& Co, 1976.

SINGHER, L., Bond strength measurement by ultrasonic guided saves, Ultrasonics, n. 35, p. 305-315, 1997

SILVERSTEIN, R.; BASSLER, G.C.; MORRIL, T.C. Identificação espectrométrica de compostos orgânicos, Rio de Janeiro: Guanabara Dois, 1975 p. 298.

SKEIST, I. Handbook of Adhesives, 4.ed. New York, N.Y., Reinhold Publishing Corporation, 1965. Cap 41, Bonding Plastics, p. 481-495.

SPECIALCHEM4ADHESIVES Jan 4, 2006. Disponível em $<$ http//www.specialchem4adhesives.com/resources/articles/article.aspx?id=1448\&q=rivet $>$. Acesso em 23/03/2011

SPECIALCHEM4ADHESIVE Mar 12, 2003. Disponível em $<$ http//www.specialchem4adhesives.com/resources/articles/article.aspx id=277\&q=insert $>$. Acesso em 23/03/2011 
PLASMATREAT

Disponível

em

$<$ http//www.plasmatreat.com/plasma_technology/fourth_aggregate_state_of_matter.html.> Acesso em 25/03/2011

STEWART, R.; GOODSHIP, V.; GUILD, F.; GREEN, M.; FARROW, J. Investigation and demonstration of the durability of air plasma pre-treatment on polypropylene automotive bumpers, Int. J. Adhesion and Adhesive, v. 25, p. 93-99, 2005.

STROBECH, C. Polyurethane adhesives. Int.J.Adhesion and Adhesives, p. 225-228, 1990.

SUGAMA, T.; KUKACHA, L.E.; CARCIELLI, N. Failure modes of polyurethane/aluminium oxide joints primed with hydrophilic macromolecules, Int. Journal of Adhesion \& Adhesives, v. 8, n. 2, p. 101-106, 1998.

TAIB, A. A., BOUKHILI, R., ACHIOU, S., GORDON, S., BOUKEHILI, H. Bonding composites. Int. J. of Adhesion and Adhesives, v. 26, p.226-236, 2006.

TECNOFIBRAS, Produtos, Disponível em:

$<$ http://www.tecnofibras.com.br/pt/produtos.htm>. Acesso em 26 jan. 2008.

TECNOFIBRAS, RTM no Brasil, Disponível em:

$<$ http://www.tecnofibras.com.br/pt/historia_rtm.pdf $>$. Acesso em 26 jan. 2008.

TOIT, F.J.; SANDERSON, R.D., Surface fluorination of polypropylene. 2. Adhesion properties. J.Fluo. Chem., v. 98, p. 98-115, 1999.

URBANSKI, J. et al.; Handbook of analysis of synthetic polymers and plastics. New York: John Wiley \& Sons, 1997.

VILAR, D.W.. Química e Tecnologia dos Poliuretanos, 3 ed., Rio de Janeiro, 2002, cap. 1, Reagentes \& Fundamentos.

WENDLANDT, W.W.; Thermal methods of analysis, 2.ed., USA, 1974.

UREPOL, Poliuretanos, Disponível em $<$ http///www.urepol.com.br/modulos/canais/descricao.php?cod=10\&codcan=9 $>$. Acesso em 25/03/2011.

WIKIPÉDIA, Poliuretano, Disponível em <http://pt.wikipedia.org/wiki/Poliuretano $>$. Acesso em 07/04/2011.

WRIGHT, C.D., MUGGE, J.M., Structural Adhesives - Chemistry and Tecnology, New York, N.Y., Plenum Press, 1986. Cap 3, Epoxy structural adhesive, p. 128.

YARLAGADDA, P.K.D.V.; CHEOK, E.C. Study on the microwave curing of adhesive joints using a temperature-controlled feedback system. J.Mat. Proc. Tech., v. 91, p. 128-149, 1999. 


\section{ANEXOA}

\section{Poliuretanos}

A obtenção de isocianatos foi primeiramente feita por Wurtz pela reação de dietilsulfato e cianeto de potássio em 1848, também é conhecida a sua síntese por fosgenação de amina obtida por Hentschel em 1884. Embora existam muitos métodos para sua síntese a fosgenação de aminas tornou-se o único método de importância industrial (Vilar, 2002).

A estrutura do isocianato tem importância na reatividade do grupo NCO, ela é aumentada por substituintes que elevem a carga positiva do carbono do grupo NCO, assim isocianatos alifáticos são menos reativos que os aromáticos. Alem disso, fatores estéricos também são importantes, substituintes volumosos próximos ao sitio de reação diminuem a velocidade da reação e alteram a especificidade do catalisador. Os principais isocianatos comerciais estão listados a seguir:

Principais isocianatos comerciais.

\begin{tabular}{|l|l|}
\hline Nome & Fórmula \\
Cientifico / Comercial / Sigla & \\
\hline 2,4-diisocianato de 1-metil-benzeno / 2,4 -tolueno diisocianato / TDI & $\mathrm{C}_{9} \mathrm{H}_{6} \mathrm{O}_{2} \mathrm{~N}_{2}$ \\
\hline 2,6-diisocianato de 1-metil-benzeno / 2,6 -tolueno diisocianato / TDI & $\mathrm{C}_{9} \mathrm{H}_{6} \mathrm{O}_{2} \mathrm{~N}_{2}$ \\
\hline Mistura de isômeros na proporção 80:20 para 2,4:2,6 / TDI 80/20 & $\mathrm{C}_{9} \mathrm{H}_{6} \mathrm{O}_{2} \mathrm{~N}_{2}$ \\
\hline Mistura de isômeros na proporção 65:35 para 2,4:2,6 / TDI 65/35 & $\mathrm{C}_{9} \mathrm{H}_{6} \mathrm{O}_{2} \mathrm{~N}_{2}$ \\
\hline 1,1-dimetileno bis (4-isocianato benzeno) / 4,4-difenil metano diisocinato / MDI & $\mathrm{C}_{15} \mathrm{H}_{10} \mathrm{O}_{2} \mathrm{~N}_{2}$ \\
\hline 1-isocianato-2-(4-isocianato fenil metilbenzeno / 2,4-difenil metano diisocinato / MDI & $\mathrm{C}_{15} \mathrm{H}_{10} \mathrm{O}_{2} \mathrm{~N}_{2}$ \\
\hline 1,1-dimetileno bis (2-isocianato benzeno) / 2,2-difenil metano diisocinato / MDI & $\mathrm{C}_{15} \mathrm{H}_{10} \mathrm{O}_{2} \mathrm{~N}_{2}$ \\
\hline 1,6-diisocianato hexano / Hexametileno diisocianato / HDI & $\mathrm{C}_{8} \mathrm{H}_{12} \mathrm{O}_{2} \mathrm{~N}_{2}$ \\
\hline 5-isocianato-1-(metilisocianato)-1,3,3-trimetil ciclohexano / Isoforona diisocianato / IPDI & $\mathrm{C}_{12} \mathrm{H}_{18} \mathrm{O}_{2} \mathrm{~N}_{2}$ \\
\hline 1,1-metileno-bis(4-isocianato ciclohexano) / 4,4-diciclohexilmetano diisocianato / HMDI & $\mathrm{C}_{15} \mathrm{H}_{22} \mathrm{O}_{2} \mathrm{~N}_{2}$ \\
\hline 1,5-diisocianato naftaleno / Naftaleno 1,5-diisocianato / NDI & $\mathrm{C}_{12} \mathrm{H}_{6} \mathrm{O}_{2} \mathrm{~N}_{2}$ \\
\hline Bis (isocianato-1-metil-1-etil)-1-3-benzeno / Meta-tetrametilxileno diisocianato / TMXDI & $\mathrm{C}_{14} \mathrm{H}_{16} \mathrm{O}_{2} \mathrm{~N}_{2}$ \\
\hline p-fenilenodiisocianato / 1,4-fenilenodiisocianato / PDI & $\mathrm{C}_{8} \mathrm{H}_{4} \mathrm{O}_{2} \mathrm{~N}_{2}$ \\
\hline
\end{tabular}

Com exceção do MDI estes isocianatos, na forma monomérica, tem pressão de vapor relativamente alta e conseqüentemente são voláteis. Quando exposta continuamente a vapores de isocianatos uma pessoa pode sofrer irritação nos olhos e mucosas podendo até ser carcinogênico. Por isso normalmente são transformados em pré-polímeros, adutos ou biuretos, para aumentar seu peso molecular e diminuir ao máximo o teor de monômeros livres nestes poliisocianatos. Obviamente para qualquer formulação ainda vão outros componentes como 
catalisadores, aditivos, inibidores, extensores de cadeia, formadores de ligações cruzadas, agentes de expansão, surfactantes, retardantes de chama, corantes, pigmentos e cargas sólidas e líquidas.

\section{Reações dos isocianatos}

A observação da estrutura eletrônica do grupo isocianato indica as possíveis estruturas de ressonância

$$
\mathrm{R}-\mathrm{N}^{-}-\mathrm{C}^{+}=\mathrm{O} \Longleftrightarrow \mathrm{R}-\mathrm{N}=\mathrm{C}=\mathrm{O} \Longleftrightarrow \mathrm{R}-\mathrm{N}=\mathrm{C}^{+}-\mathrm{O}^{-}
$$

A densidade de elétrons é menor no átomo de carbono, intermediária no nitrogênio e maior no oxigênio. Nos poliuretanos a maioria das reações dos isocianatos ocorre através da adição à dupla ligação $\mathrm{C}=\mathrm{N}$. Um centro nucleofílico contendo um átomo de hidrogênio ativo ataca o carbono eletrofílico e o átomo de hidrogênio atiço é então adicionado ao nitrogênio. Grupos aceptores de elétrons ligados ao grupamento NCO, aumentam sua reatividade e os doadores a reduzem, por isso os isocianatos aromáticos são mais reativos do que os alifáticos. A ocorrência de impedimento estérico tanto no grupo isocianato, quanto no composto contendo hidrogênio ativo provocam diminuição na reatividade. Existem cinco reações principais dos isocianatos, com polióis formando poliuretanos, aminas formando poliuréias, água formando poliuréia e liberando gás carbônico que é o principal agente de expansão nas espumas de poliuretano, grupos uretano e com uréia formando ligações cruzadas de alofanato e biureto, tais reações estão representadas abaixo:

\section{Com Polióis}

$\mathrm{R}-\mathrm{NCO}+\mathrm{R}-\mathrm{OH} \Rightarrow \stackrel{\stackrel{\mathrm{O}}{\mathrm{II}}}{\Rightarrow} \mathrm{RNH}-\mathrm{C}-\mathrm{OR}$ (uretano)

\section{Com aminas}

$$
\mathrm{R}-\mathrm{NCO}+\mathrm{R}-\mathrm{NH}_{2} \Rightarrow \mathrm{RNH}-\mathrm{C}-\stackrel{\mathrm{O}}{\mathrm{NHR}} \text { (uréia) }
$$


Com água

$\mathrm{R}-\mathrm{NCO}+\mathrm{H}_{2} \mathrm{O} \Rightarrow$ RNH-C-O -NHR (uréia) $+\mathrm{CO}_{2}$

\title{
Com Uretano
}

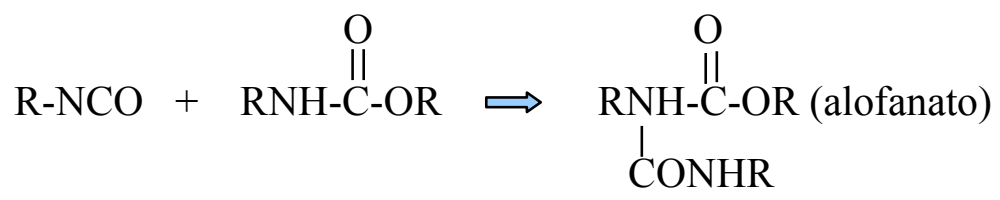

\section{Com Uréia}

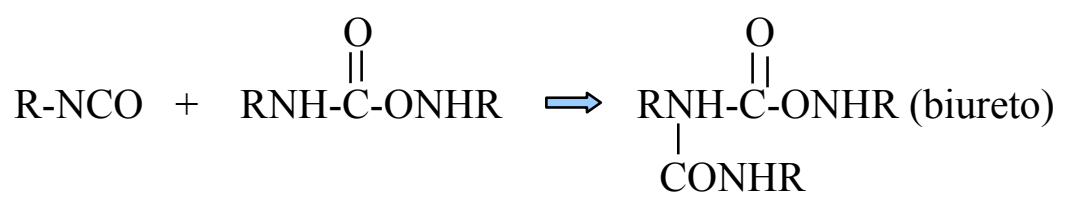

\section{Com Ácidos}

\author{
$\mathrm{R}-\mathrm{NCO}+\mathrm{R}-\mathrm{COOH} \Longrightarrow$ R-NH-CO-R (amida) $+\mathrm{CO}_{2}$ \\ 2R-NCO + R-COOH $\Rightarrow$ R-NH-CO-NR-R (acil uréia) $+\mathrm{CO}_{2}$ \\ $\mathrm{R}-\mathrm{NCO}+\mathrm{HCl} \Longrightarrow \mathrm{R}-\mathrm{NH}-\mathrm{CO}-\mathrm{Cl}$ (cloreto de carbamoila)
}

\section{Polióis}

Uma grande variedade de polióis pode ser utilizada para fabricação dos poliuretanos os polióis poliéteres são os mais utilizados e são obtidos pela polimerização de óxidos de propileno, etileno e butileno, os mais empregados são derivados do poli (óxido de propileno) glicol e copolímeros de poli(óxidos de propileno/etileno) glicóis (PPG’s). Outros polióis poliéteres como o poli(óxido tetrametileno) glicol, são utilizados em fibras e elastômeros de alto desempenho; e os polióis poliméricos são usados em espumas flexíveis de alta resiliência. Além destes temos os polióis poliésteres, que são utilizados em aplicações de alta performance, óleo de mamona, polibutadieno líquido hidroxilado etc. Normalmente polióis com peso molecular (PM) entre 1000 a 6000 e funcionalidade 1,8 a 3,0 originam espumas 
flexíveis e elastômeros, polióis de cadeira curta com peso molecular entre 250 a 1000 e alta funcionalidade entre 3 a 12 produzem cadeias rígidas com alto teor de ligações cruzadas e são usadas em espumas rígidas e tintas de alto desempenho.

\section{Tipos de Poliuretanos:}

Os poliuretanos são extremamente versáteis, mas podem ser definidos em alguns tipos básicos:

Espumas rígidas: são sistemas bicomponentes normalmente utilizados em isolamento térmico e acústico, para modelação ou para proteção de transportes de peças e equipamentos.

Espumas flexíveis: são utilizados em colchões, abafadores, peças automotivas, isolamentos acústicos, proteção de equipamentos para transportes, almofadas, bonecos e esculturas, brinquedos, etc.

Elastômeros: utilizados em várias aplicações, como encapsulamento eletrônico, amortecedores, sapatas de equipamentos, revestimentos antiderrapantes e resistentes à abrasão, acabamento em produtos promocionais, tubos e dutos, revestimentos de etiquetas, blocos de modelação, etc..

Tintas: normalmente são utilizados em aplicações onde existe a necessidade de bom acabamento, excelente brilho, resistência química, boa aderência e resistência a ação da radiação ultravioleta. Podem ser bicomponentes ou mono-componentes, normalmente os bicomponentes são os de melhor resistência em todos os sentidos.

Adesivos e selantes: os poliuretanos foram introduzidos como adesivos e selantes há 50 anos e são usados em diversos setores como construção, embalagens, aparelhos, livros, calçados, moveleiro, medicina, montagens diversas, eletroeletrônico, aeroespacial, automotivo, abrasivos, têxteis, estruturais etc. Os poliuretanos podem unir diversos materiais eficientemente com boa resistência a vibração e aplicáveis a uma grande faixa de temperaturas, produzem juntas de alta resistência substituindo sistemas de fixação mecânica evitando a distorção térmica resultante dos processos de união em temperaturas elevadas. Os adesivos de poliuretano polimerizam para formar ligações resistentes sem a necessidade de altas temperaturas em sistemas muitas vezes $100 \%$ sólidas, ou seja, sem uso de solventes ou água. A excelente adesividade dos poliuretanos é devida as elevadas forças de ligação interfacial derivadas não somente das forças físicas resultantes do contato íntimo com o 
substrato, mas também da habilidade do adesivo de poliuretanos de formar ligações de hidrogênio e ligações covalentes com diferentes substratos. Tais ligações tem excelente durabilidade, especialmente quando os adesivos são constituídos por polióis tipo poliéteres, polibutadieno líquido e derivados de óleo de mamona. No caso de substratos metálicos aderidos com adesivo de poliuretano a razão da alta resistência a umidade da ligação uretânica é atribuída à habilidade dos isocianatos de reagir com uma camada unimolecular de água, presente na superfície dos metais, como por exemplo, alumínio e aço. 


\section{ANEXO B}

\section{Projeto de junta}

Um projeto adequado de juntas estruturais, ou seja, aquelas formadas utilizando adesivos estruturais, é essencial para o sucesso da aplicação, principalmente onde a exigência seja extrema, como por exemplo, aplicações aeroespaciais e automotivas. O conhecimento das forças que atuarão sobre a junta é fundamental para projetá-la, desta maneira pode-se aproveitar com maior eficiência as vantagens do adesivo estrutural (Petrie, 2000).

Uma junta colada submetida a algum esforço mecânico pode sofrer falha através de quatro modos diferentes, conforme ilustrado abaixo , 1-falha do substrato, 2-falha na interface adesivo - substrato, também chamada falha adesiva, 3-falha no interior do corpo de adesivo, também chamada de falha coesiva e 4-falha do substrato fora do plano, mais conhecida como delaminação que ocorre apenas para materiais anisotrópicos por falha inter ou intra laminar (Petrie, 2006).

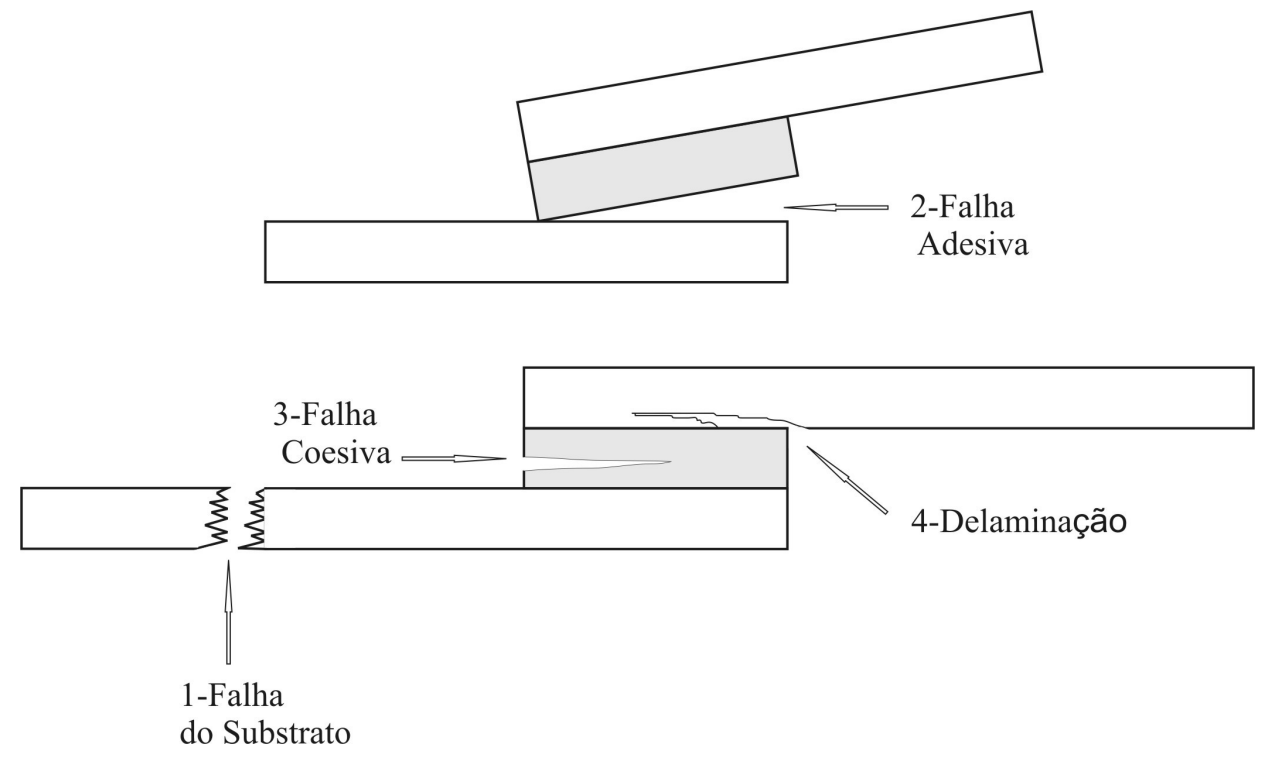

Modos de falha em uma junta.

As propriedades do substrato influenciam significativamente no detalhamento a ser escolhido. Substratos anisotrópicos, ou seja, aqueles onde as propriedades mecânicas em um ponto variam em função da orientação, como por exemplo, compósitos poliméricos e madeira, 
devem ser tratados de modo diferente, pois podem apresentar, como já destacado, uma falha fora do plano, chamada delaminação. (Quini, 2005).

\section{Esforços atuantes nas juntas}

Os esforços atuantes nas juntas são classificadas em quatro tipos, tração, cisalhamento, clivagem e peeling (Cognard, 2006).

\section{Tração (T)}

Ocorre por tracionamento da junta onde a força é aplicada com mesma direção e sentido contrário. Antes de ocorrer ruptura, tanto o adesivo como substrato, sofrem alongamento. Deve se observar que raramente a força é axial, ou seja, ocorre clivagem simultânea devendo evitar esta aplicação.

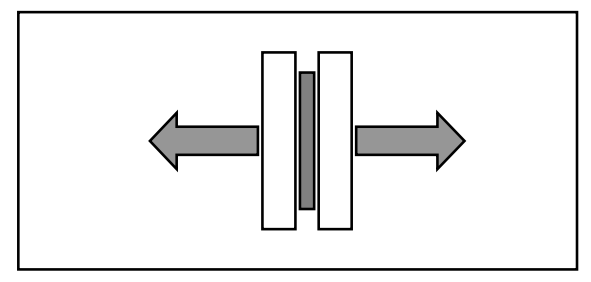

Esforço de tração.

\section{Cisalhamento (Ci)}

Ocorre por tracionamento da região da junta onde a força aplicada tem mesma direção e sentido contrário. Antes de ocorrer a ruptura adesivo e substrato sofrem alongamento máximo na área de adesão, provocando deformação da região sendo que as cargas se concentram nas extremidades do adesivo.

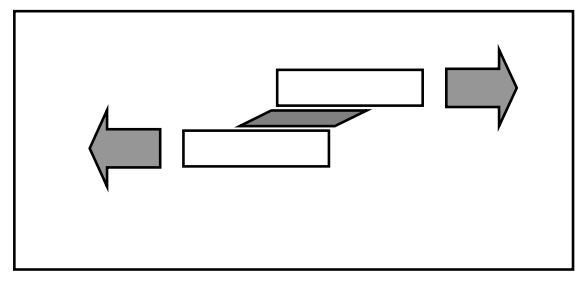

Esforço de cisalhamento 


\section{Clivagem (Cl)}

Ocorre por tracionamento de uma das extremidades da junta, também chamado efeito cunha.O adesivo e o substrato sofrem tracionamento localizado na região da força. Dependendo da rigidez do substrato e do adesivo a carga pode atuar localmente ou se distribuir ao longo da junta.

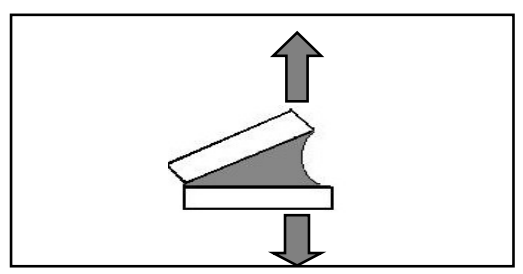

Esforço de clivagem.

\section{Peeling (P)}

Também chamado de despelamento ocorre por tracionamento de uma das extremidades da junta e quando um dos substratos for flexível. Neste caso a força atua com enorme carga de delaminação.

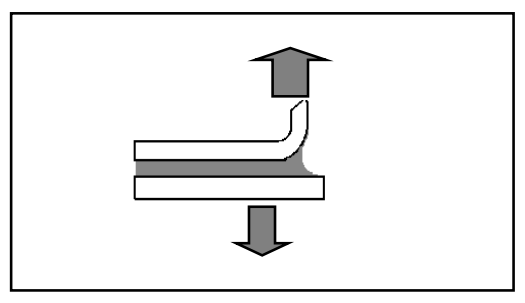

Esforço de peeling.

\section{Seleção da junta}

Para maximizar a eficiência da junta todo ponto de esforço concentrado deve ser evitado, pois a partir dele um processo de desgaste e fratura pode ser iniciado. Assim a seleção adequada do tipo de junta bem como o conhecimento das variáveis que afetam o seu desempenho é de grande valia para prevenir este o desgaste. Dentre as variáveis que a ser consideradas as mais importantes são: tipos de esforços atuantes, propriedades mecânicas do 
substrato e do adesivo, espessura de adesivo e geometria da área colada (Petrie, 2000).

Primeiramente devem ser avaliadas as forças atuantes em uma determinada junta, suas direções e intensidades e quais tipos de esforços elas causarão, que podem ser cisalhamento, tração, clivagem e peeling, sabendo-se que em geral as resistências dos adesivos aos esforços seguem a seguinte ordem decrescente: cisalhamento $>$ tração $>$ clivagem $>$ peeling. Alguns autores costumam inserir os esforços de compressão, porém se em uma junta o adesivo esta sob esforço de compressão, entende-se que a junta não esta tem nenhuma ação efetiva, cumprindo apenas a função de transferir força entre dois substratos, não se considerando como um tipo de esforço importante.

De fato a experiência mostra que juntas que minimizam a clivagem e o peeling e favorecem o cisalhamento e a tração apresentam melhor resultado e durabilidade (Cognard, 2006).

As propriedades dos substratos influenciam significativamente no detalhamento a ser escolhido. Assim, deve-se considerar, por exemplo, que substratos laminados como compósitos podem apresentar delaminação, sendo que esse dano pode ser evitado basicamente aumentando-se a área de colagem, fenômeno que não ocorre com substratos homogêneos como metais, cerâmica, borracha e plásticos (Shields, 1976).

A flexibilidade ou a rigidez de um substrato refere-se ao comportamento que ele terá quando for submetido a um esforço específico da junta. Um substrato flexível, devido a sua maior deformação quando sujeito a um pequeno esforço mecânico, tenderá a apresentar maior tendência a clivagem ou peeling. Tal propriedade é muito importante, pois em situações de uso torna-se quase impossível eliminar totalmente a clivagem e os adesivos flexíveis têm demonstrado maior resistência ao longo do tempo de uso do que aqueles mais rígidos. Pode-se verificar este comportamento ao cisalhamento no uso do adesivo estrutural poliuretânico, que embora não apresente resistência tão elevada, resiste melhor ao longo do tempo pela sua maior flexibilidade (Skeist, 1965).

A tabela a seguir apresenta sugestões em função do tipo de junta seja ela do tipo ângulo, perpendicular, topo e superfície para substratos laminado, homogêneo, rígido e flexível, em uma escala crescente de eficiência pela atribuição de notas de 1 a 14. Nota-se que as juntas do tipo ângulo e perpendicular são as que recebem menor nota, pois devido a sua natureza resultam em maior presença dos esforços de clivagem e peeling, enquanto que as de topo a predominância dos esforços são de tração e por fim a que recebe melhores notas é a de superfície, onde o esforço predominante é o de cisalhamento. 
Sugestões de juntas

\begin{tabular}{|c|c|c|c|c|c|c|c|c|c|c|c|c|c|c|c|c|c|}
\hline \multirow{3}{*}{\multicolumn{2}{|c|}{$\begin{array}{c}\text { Tipo de Junta } \\
\text { Tipo de substrato }\end{array}$}} & \multicolumn{4}{|c|}{ Angulo } & \multicolumn{4}{|c|}{ Perpendicular } & \multicolumn{4}{|c|}{ Topo } & \multicolumn{4}{|c|}{ Superfície } \\
\hline & & \multicolumn{2}{|c|}{ Homogêneo } & \multicolumn{2}{|c|}{ Laminado } & \multicolumn{2}{|c|}{ Homogêneo } & \multicolumn{2}{|c|}{ Laminado } & \multicolumn{2}{|c|}{ Homogêneo } & \multicolumn{2}{|c|}{ Laminado } & \multicolumn{2}{|c|}{ Homogêneo } & \multicolumn{2}{|c|}{ Laminado } \\
\hline & & $\mathrm{R}$ & $\mathrm{F}$ & $\mathrm{R}$ & $\mathrm{F}$ & $\mathrm{R}$ & $\mathrm{F}$ & $\mathrm{R}$ & $\mathrm{F}$ & $\mathrm{R}$ & $\bar{F}$ & $\mathrm{R}$ & $\mathrm{F}$ & $\mathrm{R}$ & $\mathrm{F}$ & $\mathrm{R}$ & $\mathrm{F}$ \\
\hline \multirow{2}{*}{ Homogêneo } & Rígido & 1 & 2 & 3 & 4 & 5 & 6 & 7 & 8 & 9 & 10 & 11 & 12 & 13 & 14 & 13 & 14 \\
\hline & Flexível & 2 & - & 2 & - & 6 & 6 & 6 & 8 & 10 & 10 & 10 & 12 & 14 & 14 & 14 & 14 \\
\hline \multirow{2}{*}{ Laminado } & Rígido & 3 & 2 & 3 & 4 & 7 & 6 & 7 & 8 & 11 & 10 & 11 & 12 & 13 & 14 & 13 & 14 \\
\hline & Flexível & $\overline{4}$ & - & 4 & - & 8 & 8 & $\overline{8}$ & 8 & 12 & 12 & 12 & 12 & 14 & 14 & 14 & 14 \\
\hline
\end{tabular}

$\mathrm{R}=$ rígido

$\mathrm{F}=$ flexível

A espessura do adesivo também pode interferir no comportamento da junta. Em geral espessuras entre $0,01-1,0 \mathrm{~mm}$ apresentam maior resistência a tração e ao cisalhamento, porém com resistência a inferior a clivagem e ao peeling. Por outro lado quando a espessura for acima de 1,0mm, o adesivo absorve elasticamente parte do esforço quando submetido a clivagem e ao peeling, apresentando assim maior resistência a estes esforços do que juntas mais finas, embora tenha diminuído sua resistência a tração e cisalhamento. 


\section{ANEXO C}

\section{Adesivo uretânico}

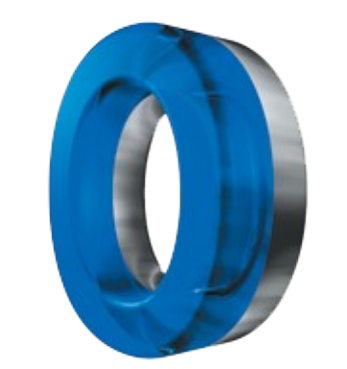

\section{MASTERPOL'}

\section{MASTERPUR ESTRUTURAL 300 \\ Informativo Técnico e de}

\section{Segurança do Produto}

MASTERPUR Estrutural 300 é um adesivo formulado para colagem de substratos de PRFV (fiberglass) entre si, sobre superfícies metálicas (alumínio, aço carbono, e superfícies galvanizadas) ou ainda para colagem de conjuntos metálicos. O tempo de manuseio, relativamente curto, é ideal para aplicação por sistema mecanizado, embora seja possível sua utilização também por sistema manual. Depois de curado, o produto tem excelente resistência mecânica e não é sensível à água ou umidade.

\section{Propriedades Típicas}

$>$ Resistência ao Cisalhamento:

* RTM x RTM: 6,1MPa

- SMC x SMC: $5,8 \mathrm{MPa}$

* Aço Zincado Preto x Aço Zincado Preto: 10,7MPa

\section{Recomendações e Cuidados na Utilização}

O produto deve ser aplicado sobre superfície seca e limpa, isenta de gordura, óleo ou graxa. A não observância destes fatores irá prejudicar a cura e aderência do produto e comprometer o resultado esperado.

Para garantir a perfeita "ancoragem" do adesivo sobre as superfícies a serem coladas, estas devem ser lixadas com o emprego de lixa média; esta operação tem por finalidade aumentar a "rugosidade" da superfície e eliminar resíduos de desmoldantes normalmente existentes nas peças moldadas em PRFV. As propriedades típicas acima indicadas foram obtidas em peças previamente lixadas. 


\section{Aplicação do Produto}

7. Na aplicação por processo mecânico, seguir as instruções de operação do equipamento, de modo a obter a mistura na proporção volumétrica de 4 partes de Componente A para 1 parte de Componente B. Na aplicação manual, adicionar todo o conteúdo da embalagem do Componente $\mathbf{B}$ à embalagem do Componente $\mathbf{A}$ e misturar completamente, até que o material esteja homogêneo e apresente cor uniforme; a agitação mecânica facilita e agiliza o processo de mistura. Para este processo pode ser utilizada uma haste metálica com terminação em forma de misturador ou hélice (aproximadamente $5 \mathrm{~cm}$ de diâmetro), adaptada a uma furadeira elétrica manual; acionar o equipamento somente após a imersão na mistura, para que o produto não seja expelido para fora do recipiente. Evitar o impacto da hélice contra a parede da embalagem para não provocar seu rompimento acidental.

8. Caso seja necessário misturar quantidades menores do que as fornecidas na embalagem padrão, utilizar sempre na mistura a proporção de $\mathbf{1 0 0 g}$ de Componente A para $\mathbf{2 5 g}$ de Componente B. A mistura incorreta (proporção errada) ou imperfeita (não homogênea) prejudica a cura ("secagem") do adesivo e compromete o resultado da colagem.

9. O tempo útil ("pot-life") para manuseio do produto, após a mistura, é de aproximadamente 5 minutos a $25{ }^{\circ} \mathrm{C}$; este tempo será maior para temperaturas mais baixas e menor para temperaturas mais altas. $\mathrm{O}$ "pot- life" pode ser entendido como o ponto a partir do qual a reação química entre os dois componentes, que se inicia no momento da mistura, provoca elevação da temperatura e sensível e rápido aumento da viscosidade do material; após o "pot-life", o adesivo não pode mais ser aplicado e as peças coladas não devem ser movimentadas.

10. Aplicar o produto sobre uma das superfícies, juntar a outra parte e exercer pressão sobre o conjunto por pelo menos 10 a 15 minutos, intervalo de tempo necessário para que o produto atinja cerca de $70 \%$ da cura total e tenha estabilidade suficiente para manter a união das partes sem a necessidade de emprego de apoio ou compressão. Este período pode, eventualmente, ser reduzido ou ampliado, dependendo dos materiais e da conformação das peças a serem coladas. Alternativamente, pode ser utilizado o processo de "filetagem", no qual se utiliza recipiente do tipo bolsa ou saco plástico para receber a mistura e, através de orifício com tamanho apropriado, aplica-se o produto, formando os "filetes" na espessura desejada. Observar, entretanto, que as condições reais de utilização poderão determinar alterações nas quantidades a serem utilizadas, de modo que o usuário deverá, através de experimentação, escolher o procedimento ideal. As propriedades típicas do produto serão obtidas após a cura final do produto, que acontece transcorridas 24 horas da aplicação.

11. A limpeza dos utensílios utilizados e de eventuais excessos do adesivo deve ser feita o mais rapidamente possível, ainda durante o "pot-life", com estopa ou pano limpo e o uso de álcool ou aguarrás.

12. Evite o contato dos Componentes A e B, com água ou umidade durante a mistura e sua posterior aplicação. Não utilize os componentes A e B separadamente e não reutilize as embalagens.

\section{Características Físico - Químicas}

Componente A - Composição Básica: Polióis, Cargas e Aditivos. Aspecto: Pasta Viscosa Branca Teor de Sólidos: 99,5 - 100\% 
Densidade a $25^{\circ} \mathrm{C}: 1,20-1,30\left(\mathrm{~g} / \mathrm{cm}^{3}\right)$

Consistência: $4,2-6,7(2 \mathrm{~g} / 2 \mathrm{~min} / 2 \mathrm{~kg})$

Componente B - Composição Básica: Isocianatos Polifuncionais e Aditivos.

Aspecto: Pasta viscosa Marrom

Densidade a $25^{\circ} \mathrm{C}: 1,05-1,10\left(\mathrm{~g} / \mathrm{cm}^{3}\right)$

Mistura - 100 Componente A / 25 Componente B (Relação em unidades de massa)

Gel Time a $35^{\circ} \mathrm{C}: 3$ - 6 minutos

\section{Embalagem e Validade}

MASTERPUR Estrutural 300 é fornecido em conjuntos (Componente A e Componente B) de $250 \mathrm{~kg}$. O Componente A é embalado em tambores metálicos com $65 \mathrm{~kg}$ e o Componente $\mathrm{B}$ em tambores metálicos com $55 \mathrm{~kg}$, devendo ser armazenado em local seco e ventilado, protegido de intempéries e a temperatura abaixo de $30^{\circ} \mathrm{C}$. Nestas condições, e acondicionados em suas embalagens originais, os dois componentes tem validade de 12 meses a contar da data de fabricação. Mediante solicitação especial, poderá ser verificada a viabilidade de fornecimento em embalagens diversas das acima indicadas.

\section{Informações Sobre Segurança do Produto}

Componente A: Não é inflamável nem irritante.

Componente B: Combustível, levemente irritante e tóxico se inalado ou absorvido em altas concentrações.

\section{Emergência e Primeiros Socorros:}

Contato com a pele: Lavar com água corrente e sabão.

Contato com os olhos: Lavar com água corrente por 15 minutos e consultar um oftalmologista.

Ingestão acidental: Não provocar vômito e procurar auxílio médico.

\section{Combate a Incêndios:}

Manter afastado do calor, centelhas e chama; em caso de fogo, utilizar extintores de pó químico seco, dióxido de carbono ou espuma.

Vazamento acidental:Isolar o local e remover o produto utilizando material absorvente não inflamável; evitar o contato com a água.

$$
\text { Rev.03 - Agosto } 2008 .
$$

ATENÇÃO : Esperamos que as informações e recomendações aqui contidas sejam úteis aos clientes e usuários do produto, os quais, entretanto, devem certificar-se quanto à sua adequação às finalidades a que se destina, mediante a realização de testes para os usos e processos pretendidos. A aplicação, o uso e o processamento do produto estão fora de nosso controle e são de inteira responsabilidade do usuário. Nossa assessoria técnica - verbal, escrita ou através de testes - é concedida sem implicar em qualquer garantia, inclusive com relação a direitos de terceiros. Garantimos a qualidade do produto de acordo com as características físico-químicas especificadas. 


\title{
ANEXO D
}

\author{
Tratamento com plasma
}

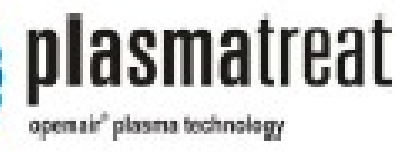

\section{FLUME $^{\mathrm{TM}}$ \\ Plasma Systems}

What is Plasma?

Plasma is the fourth state of matter, caeated by charging a gas with a large amount of energy. While plasma behaves much like gas, it emits light and is highly active as it contains free ions and electrons.

solid $\longrightarrow$ liquid $\longrightarrow$ gas $\longrightarrow$ plasma

\section{FLUME ${ }^{-\infty}$ Plasma Systems}

FLUME " plasma systems, introduced by Plasmatreaf", are based on patented Openair $=$ plasma technology. They use compressed air and power to generate atmospheric pressure plasma. The plasma is blasted on to the surface of any material to prepare a surface for bonding application. The primary effect of a FLUME ${ }^{\text {w }}$ plasma system is a pristine surface down to molecular (nanometer) scale. It eliminates hydrocarbon and silicone based contaminations that exist on any technically clean surface. This is achieved by blasting the surface with energized air ions. On organic surfaces, a large amoumt of polar, mainly hydrosyl and ketoric, groups are created. This greatly enhances surface adhesion.

FLUME plasma systems are urilized across a wide range of industries as surface preparation for reliable, environmentally friendly, and cost

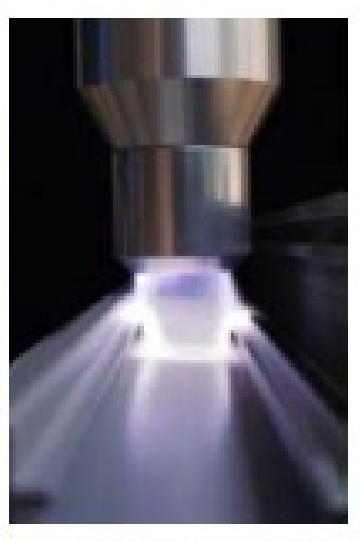
effective bonding solutions. The prepared surface is used for adhesives, coatings, inks, overnsolding etc. and the bond proctuced is incredibly reliable and durable, in some cases factors better than with traditional surface preparation.

Openair" plasma technology has been introduced in companies such as BMW, DaimlerChrysler. Volkswagen, Cooper Standard, Magna, Visteon, Coca Coln, Kraft, Lego, Nokia, since 1995, and on the North American market since the year 2000 .
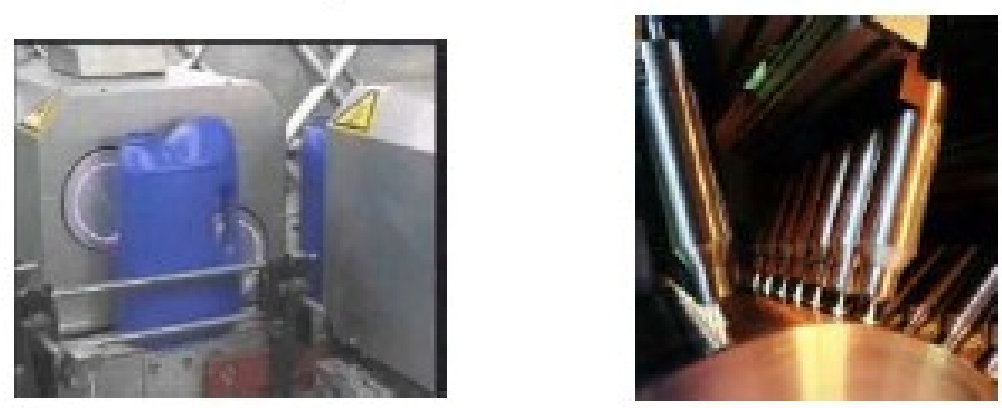

Plasma Treal" North America Inc., 2810-1 Argentin Road, LSN 8L.2 Missiumgn, ON, Cansda 뜨w.PlasmaTreat com phoos 9058162350, fax 416352 5947, info/APlarmaTroat com

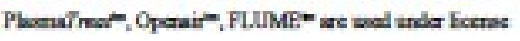




\section{Features}

It utilizes a homogeneous, zero-voltage, flame-like plasma beam to prepare a surface prior to adhesive application, coating or printing

A FLUME ${ }^{-\infty}$ plasma system worls at atmospheric pressure conditions in assembly lines at industrial speeds, in some cases up to 3000 feet per minute.

It can be applied to all classes of materials - plastics, rubber, glass, ceramics, metals, as well as metallic and non-metallic surfaces combined (eg. PC-board), composites (e.g. glass-fiber reimforced plastics), and delicate cellular (foamed) materiak.

It can effectively treat complex three-dimensional shapes even with grooves and small cavities as well as wide flat surfaces, and is compact and easy to integrate fired or on a robot into the production line

It allows for simpler design methodology with emphasis on reduced cost

It is easy in operation and handling and low in running and maintenance cost. It only requires clean compressed air (60-90 psi) and 480 (or 600) Volt, 3-phase electricity for industrial systems.

It is clean, environment friendly and worlylace safe. It eliminates the need for toric primers and solvents bilse toluene,

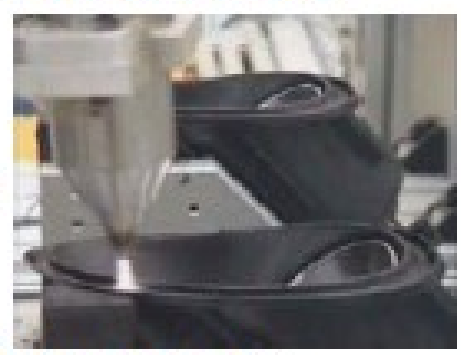
benzene and acetone in assembly lines. It is energy efficient, and contact and wear free.

It is QS 9000 compliant and has proven reliability in the production line.

Some low surface energy materials that can be treated

Pp - Polypropylene

PE - Polyethylene

PA - Nylon

PS - Polystyrene

TPO - Thermoplastic olefins

TPE - Thermoplastic elastomers

EVA, EPDM, Silicones

And many more (please ask for your specific application)

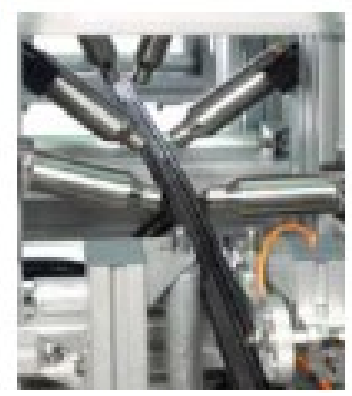

Plastatreat" North America Ine, 2810-1 Argentia Road, L.SN 81.2 Missiscangh, ON, Cinala

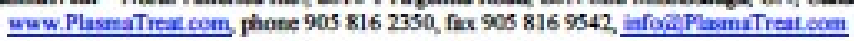

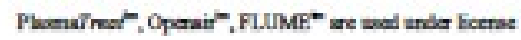


Why is the FLUME ${ }^{\text {tm }}$ plasma system better than other traditional methods?

Reliability has always been an issue when you need to bond, coat or print on the surfaces of various materials such as plastics, rubber, metals, glass, and composites. They require sufface preparation especially when they have low energy surfaces. The traditional surface treatment methods used by the industry today are:

Mechamical (Brushing, Grit Blasting ...), Fluid (Solvent Wipe, Powerwash,...)

Chemical (Acid Etch, Priming ...)

Physical (Corona, Flame Treatment, Low Pressure Plasma)

The unique combination of features of FLUME plasma systems makes them a superior method of surface preparation over all these other options. Their introduction to industry has opened the door for the use of many "difficult" materials with reliable bonding. With FLUME plasma system surfice preparation, the bullk properties of an engineering material can be optimized (which often leads to poor surface properties) while still realizing high quality bonds. In addition, adhesives and coatings can also be optimized, often allowing a move to water based systems. The result is high quality bonds with cost effective, environmentally friendly adhesives and coatings.

Who can use FLUME ${ }^{\text {m }}$ plasma surface preparation?

Anybody who needs reliable bonding!

Automotive industry, electronics and medin, consumer packaging and medical are some of the sectors that are currently using FLUME plasma surface preparation.

There are many applications on the following materials:

- Thermoplastics

- Elastomers

- Glass and ceramics

- Metals

- Composites (eg. glass-fiber reinforced plastics)

- Metal not-metal combinations (e.g. PC Boards)

- Foamed or dense materials

- Films or linear extrusion

- 3 dimensional parts
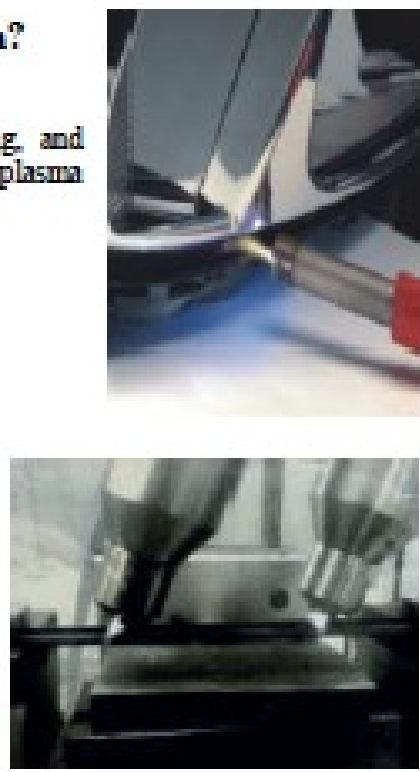

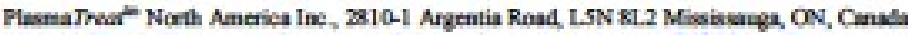
wuw.PlasmaTrexicom phote 9058162350 , fax 9058169542 , infogal PlomeTreateon

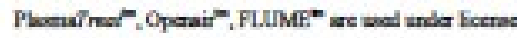


Surface Tension

To obtain optimum surface watting with a liquid (printing ink, adhesive), a substrate's surface tension is considered as the major percmetar. The surfaca tension is considered as a relative measure for evaluating the printing ink coverage and the expected bonding of the printing ink, a layer of edhesive or some other coating on the substrate.

Poor surface wetting

Plastics have a low surface tension betwean $<28 \mathrm{mN} / \mathrm{m}$ and $40 \mathrm{mN} / \mathrm{m}$. Expariance hes shown, only surfece tensions starting at $38-42 \mathrm{mN} / \mathrm{m}$ facilitate good adhesion conditions. A clear improvernent in the surface tension can be achieved through an optimal pre-treatment, e.g. with atmospheric pressure plesma from plasmatreat". Thereffore, valuas of up to $72 \mathrm{mN} / \mathrm{m}$ are possible on many plastics (water fully wets the smooth surfacal

Good surface wetting

Evaluation of test results obtained with plasmatreat ${ }^{\bullet}$ test inks

As with every test process, critical examination of the tast results is neces. sary, even when determining the surface tensions using test inks

$$
\text { Adherence is not affected by the surface tension! }
$$

The ascertained surfece tersion can only ever be a maasure of the current condition of the substrate. Experience has shown, surface tension dacreases in line with tha storege time. In functioning processess, testing surface tension with plasmatreat" test inks is an exrellent tool for quality assur. ance within the menufacturing process providad that the adhesive or the printing ink and the condition of the surface are harmonised

The maximum error rate as a ressult of a reading equals $2 \mathrm{mN} / \mathrm{m}$. In test series with repeat testing, the error tolerances drop accordingly. The attained test values are relative values and are only conditionally comparable to other test methods.

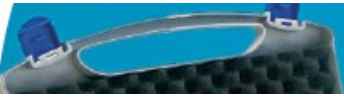

plasmatreat test inks are available in three different series

Series A

- espacially suitable for warmer surfaces - longer readout time

- not suitable for PVC surfacas

- toxic

manufactured according to DN 53364 Aveilable from $30-56 \mathrm{mN}$

(in increments of twos)

Series B

- suitable for all common surfacas

- partly toxic

(depending on the surface tension value) - manuficctured according to DNN 53364 - availabla from $28-72 \mathrm{mN} / \mathrm{m}$ (in increments of twos)

Series C

- suitable for all common surfacas

mon-toxic, non-datimental to health

- availabla from $28-72 \mathrm{mN} / \mathrm{m}$ (in increments of twos)
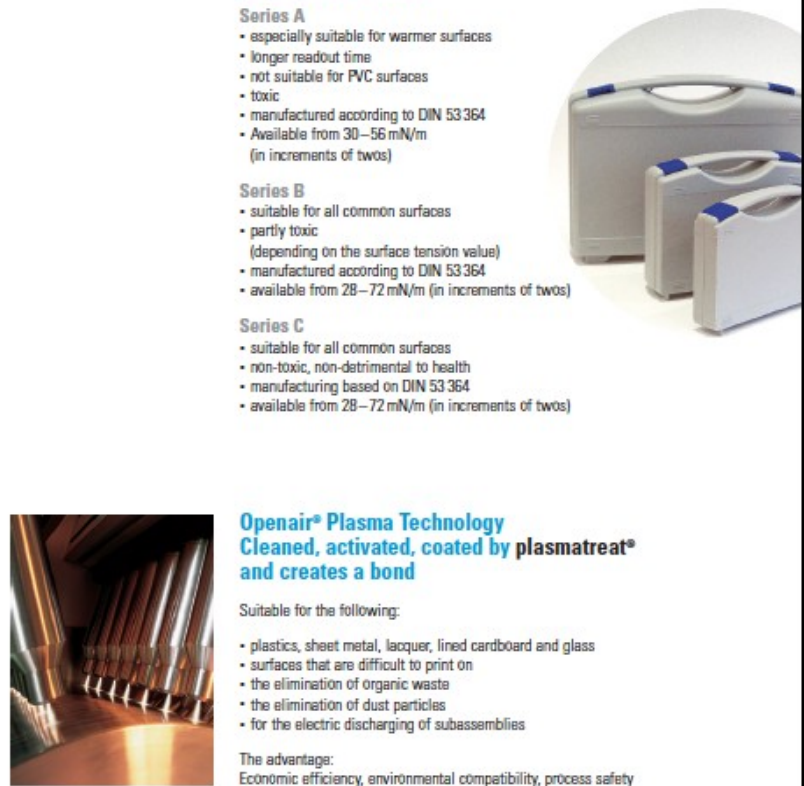

Openairs Plasma Technology

Cleaned, activated, coated by plasmatreat

and creates a bond

Suiteble for tha following

- plastics, shaet matal, lacquer, lined cardboard and glass

that are difficult to print on

the elimination of organic wast

for the electric discherging of subassamblies

The advartage: 